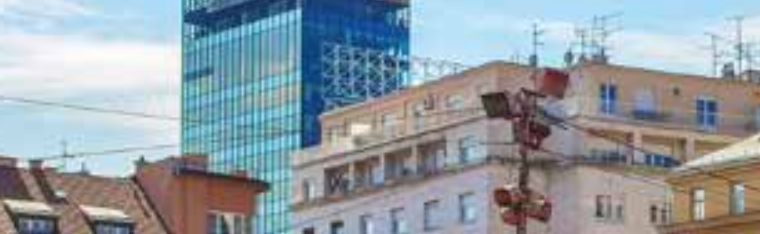

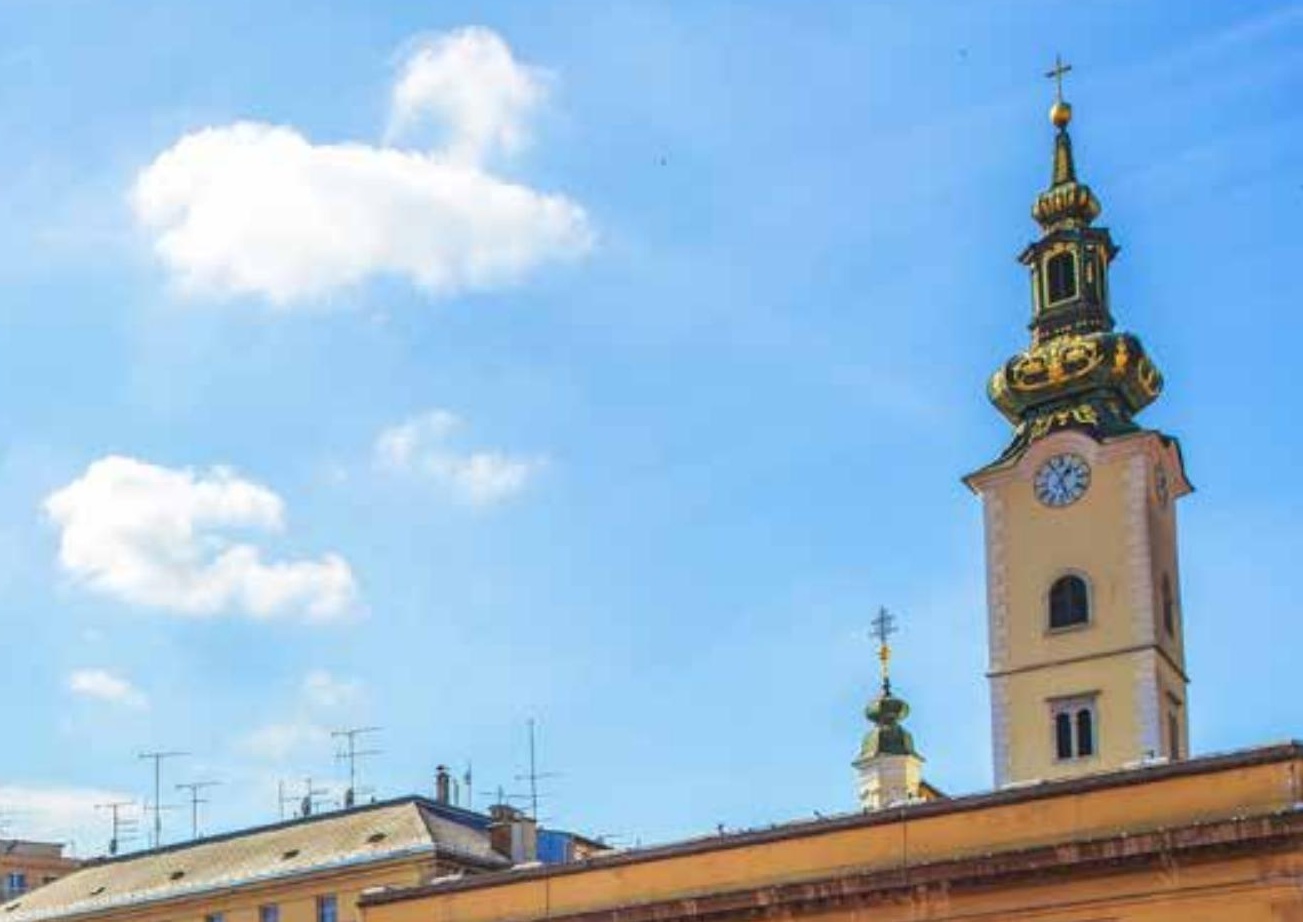

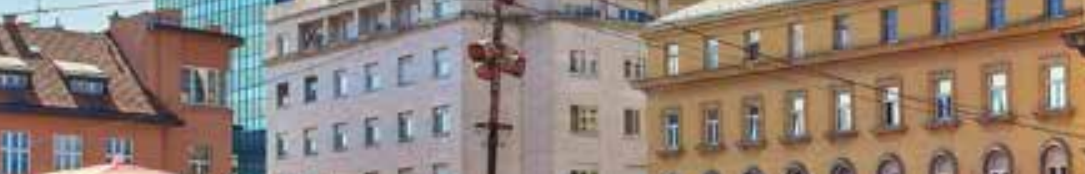

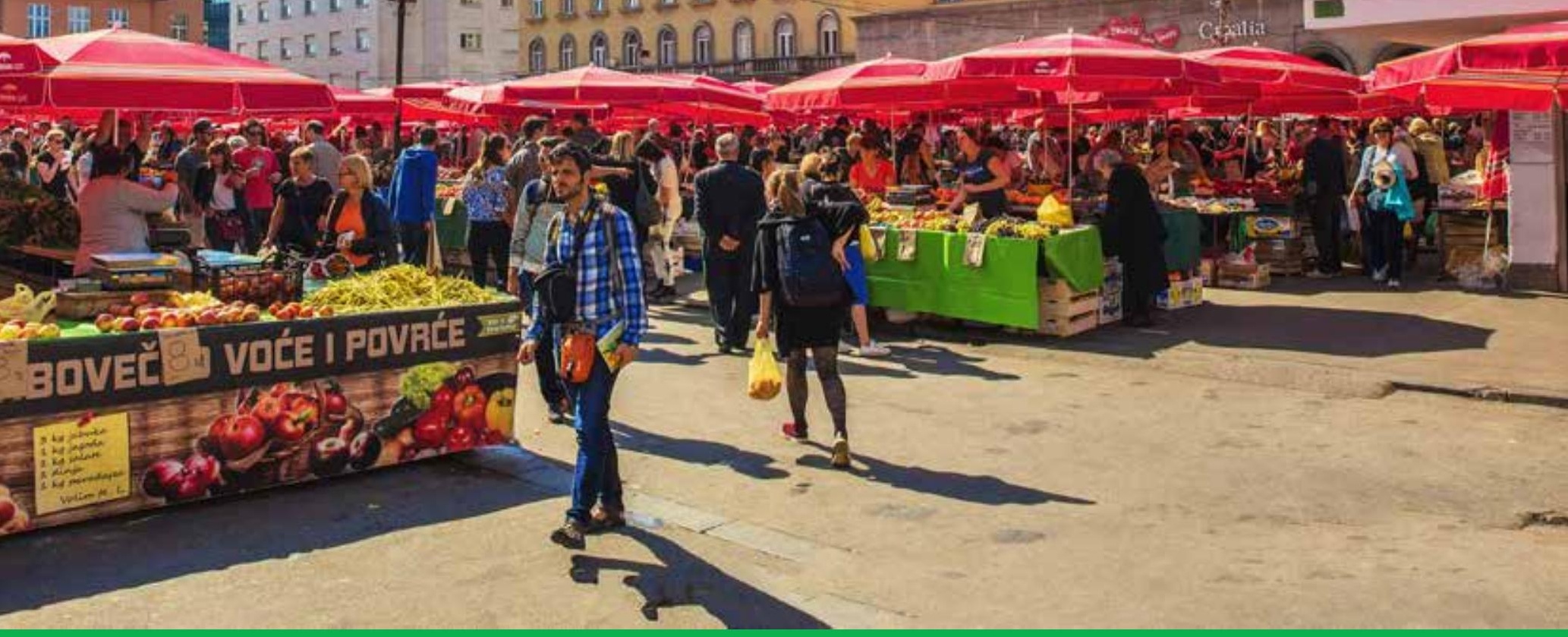

\title{
Business opportunities for Croatian fruit and vegetables growers
}

Katja Logatcheva, Michiel van Galen, Bas Janssens, Gerben Splinter

WAGENINGEN

UNIVERSITY \& RESEARCH 



\section{Business opportunities Croatian fruit and vegetables growers}

Katja Logatcheva, Michiel van Galen, Bas Janssens, Gerben Splinter

This study was carried out by Wageningen Economic Research and was commissioned and financed by the European Bank for Reconstruction and Development

Wageningen Economic Research

Wageningen, March 2018

REPORT

2018-002

ISBN 978-94-6343-761-5 
Logatcheva, K., M.A. van Galen, S.R.M. Janssens, G.M. Splinter, 2018. Business opportunities for Croatian fruit and vegetables growers. Wageningen, Wageningen Economic Research, Report 2018-002. 102 pp.; 55 fig.; 11 tab.; 13 ref.

The European Bank for Reconstruction and Development (EBRD) has asked Wageningen Economic Research to carry out a study on the Croatian fruit and vegetables sector and value chain to make a contribution to the enhancement of the position of growers in the value chain. The study shows that the Croatian fruit and vegetables farming sector has opportunities in the development of the domestic supermarket channel and tourism markets. In the short run, growers will benefit from improving yields, efficiency and product quality. Increasing supply volumes and hence marketing efficiency can also be achieved by improved cooperation between farmers and further land reform measures. A good competitive position on the domestic market is a necessary pre-condition for increasing exports. In the longer term, in order to be able to develop export markets, the sector will benefit from the development of a buyers network, marketing, EU quality labels, and export logistics.

Key words: Croatia, fruit and vegetables sector, market opportunities

This report can be downloaded for free at https://doi.org/10.18174/443227 or at www.wur.eu/economic-research (under Wageningen Economic Research publications).

(C) 2018 Wageningen Economic Research

P.O. Box 29703, 2502 LS The Hague, The Netherlands, T +31 (0)70 3358330 ,

E communications.ssg@wur.nl, http://www.wur.eu/economic-research. Wageningen Economic Research is part of Wageningen University \& Research.

\section{(cc) BY-NC}

For its reports, Wageningen Economic Research utilises a Creative Commons Attributions 3.0 Netherlands license.

(C) Wageningen Economic Research, part of Stichting Wageningen Research, 2018

The user may reproduce, distribute and share this work and make derivative works from it. Material by third parties which is used in the work and which are subject to intellectual property rights may not be used without prior permission from the relevant third party. The user must attribute the work by stating the name indicated by the author or licensor but may not do this in such a way as to create the impression that the author/licensor endorses the use of the work or the work of the user. The user may not use the work for commercial purposes.

Wageningen Economic Research accepts no liability for any damage resulting from the use of the results of this study or the application of the advice contained in it.

Wageningen Economic Research is ISO 9001:2008 certified.

Wageningen Economic Research Report 2018-002 | Project code 2282300160

Cover photo: Ungvari Attila/Shutterstock.com 
Ter nagedachtenis aan onze collega In loving memory of our colleague

Jo Wijnands (1953 - 2018) 



\section{Contents}

$\begin{array}{ll}\text { Preface } & 7\end{array}$

$\begin{array}{ll}\text { Summary } & 8\end{array}$

S.1 Market opportunities $\quad 8$

S.2 Market characteristics $\quad 8$

$\begin{array}{ll}\text { S.3 Method } & 9\end{array}$

1

$\begin{array}{ll}\text { Introduction } & 10\end{array}$

$\begin{array}{lll}1.1 & \text { Background of the study } & 10\end{array}$

$\begin{array}{lll}1.2 \text { Goal } & 10\end{array}$

$\begin{array}{lll}1.3 \text { Method } & 10\end{array}$

1.4 Report outline $\quad 11$

$\begin{array}{ll}\text { Production and trade } & 12\end{array}$

2.1 Introduction $\quad 12$

2.2 Area, volume, value and yields $\quad 12$

2.2.1 Cultivated area fluctuates $\quad 12$

2.2.2 Different production volume developments per crop $\quad 15$

$\begin{array}{ll}2.2 .3 \text { Most production value from fresh vegetables } & 17\end{array}$

2.2.4 Production efficiency: yields 18

$\begin{array}{lll}2.3 & \text { Below self-sufficiency for most products } & 23\end{array}$

$3 \quad$ Value chain analysis $\quad 24$

$\begin{array}{lll}3.1 & \text { Introduction } & 24\end{array}$

$\begin{array}{ll}3.2 & \text { Value chain: from grower to consumer }\end{array}$

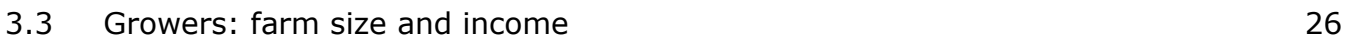

3.3.1 Many small and unspecialised farms 26

3.3.2 Croatian horticulture income lagging behind 32

3.4 Fruit and vegetables wholesale: several big players, low profitability 33

3.5 Processing: Croatian firms process locally grown products 34

3.6 Retail: a changing landscape $\quad 35$

3.7 Cooperation between chain actors: horizontal and vertical 37

3.8 Contracts and pricing: mixed practices $\quad 39$

3.9 Summary of structure, conduct, performance 40

4

$\begin{array}{ll}\text { Business environment } & 44\end{array}$

$\begin{array}{lll}4.1 & \text { Introduction } & 44\end{array}$

4.2 Climate, labour and land $\quad 44$

$\begin{array}{lll}4.3 & \text { Economic and business climate } & 47\end{array}$

4.3.1 Positive economic trends $\quad 47$

$\begin{array}{ll}\text { 4.3.2 Rise of tourism } & 47\end{array}$

4.3.3 Adequate general business climate $\quad 48$

$\begin{array}{lll}4.4 & \text { Related and supporting industries } & 49\end{array}$

$\begin{array}{lll}4.5 & \text { Enabling environment } & 50\end{array}$

$5 \quad$ International market opportunities

5.1 Introduction $\quad 54$

5.2 International opportunities: from nearby to further away 55 
6.1 Introduction

6.2 Opportunities and examples

7.1 Main conclusions

7.2 Recommendations

References and websites

Appendix 1 Selection of products 69

Appendix 2 Benchmark countries

Appendix 3 International market windows 81

Appendix 4 Summary of MABA statistics 91

Appendix 5 List of interviewees 98

Appendix 6 Country profile of Croatia 


\section{Preface}

After Croatian accession into the EU in 2013, the market environment for fruit and vegetables growers has changed considerably. The sector has been faced with a range of challenges and is looking for new opportunities to develop. This study is the result of a project of The European Bank for Reconstruction and Development (EBRD). Wageningen Economic Research has interviewed growers, wholesalers, processors and retailers in the Croatian fruit and vegetables chain to analyse its current performance and identify potential new market opportunities and improvements.

We wish to offer a special word of gratitude and remembrance to our dear colleague Jo Wijnands, who passed away. He was a driving force behind this research. We will dearly miss him.

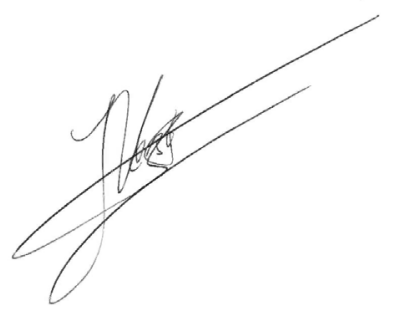

Prof.dr.ir. J.G.A.J. (Jack) van der Vorst General Director Social Sciences Group (SSG)

Wageningen University \& Research 


\section{Summary}

\section{S.1 Market opportunities}

The Croatian fruit and vegetables farming sector has opportunities in the development of the domestic supermarket channel and tourism markets. In the short run, growers will benefit from improving yields, efficiency and product quality. Increasing supply volumes and hence marketing efficiency can also be achieved by improved cooperation between farmers and further land reform measures. A good competitive position on the domestic market is a necessary pre-condition for increasing exports. In the longer term, in order to be able to develop export markets the sector will benefit from the development of a buyers network, marketing, EU quality labels, and export logistics.

- Croatia has an attractive consumer market for fruit and vegetables. Fruit and vegetables are relatively popular in Croatia, where the daily consumption of fruit and vegetables is above the EU average. While experiencing relatively fast economic growth in their country, Croatian consumers increasingly demand value added products of high quality, including fruit and vegetables. See 4.3.1 >

- Supermarkets have become the most important sales channel of fresh fruit and vegetables to Croatian consumers. Supermarkets require safe products and prefer guaranteed supply of high quality products at lower prices. Supermarkets buy fresh fruit and vegetables from both domestic and foreign suppliers. See $3.6>$

- Croatia has a developed fruit and vegetables processing industry. The Croatian processing industry prefers locally grown produce of good quality. A part of these products is produced by smaller growers on long term contracts with the industry. Contract farming can be a sustainable alternative for small growers. However, in the long term, buyers will always seek for more efficient methods of raw material supply, which means that growers in this market channel must improve their competitiveness by implementing efficient growing techniques and both horizontal and vertical cooperation. See $3.5>$

- Also fast growing tourism has created an interesting market for food, both in terms of growing consumption during the tourism season and as a way to promote Croatia and Croatian products abroad. See 4.3.2 >

- A good competitive position on the domestic market is a necessary pre-condition for increasing exports. There are opportunities for selling at higher prices in export markets in and outside Europe. In order to develop their exporting position, the growers will benefit from the development of a buyers network, good export marketing strategies, EU quality labels, and export logistics. See $\mathbf{5}$ and $6>$

- Improving yields and efficiency, developing niche market products, improving knowledge, experience and entrepreneurship, strengthening cooperation, improving product safety and quality e.g. by implementing certification programmes, and investment in (cold) storage and agro-logistics are the main focus areas for improving competitiveness. In addition, speeding up the land reform (land utilisation and consolidation) will contribute to scaling up farms. See 4.2, 5 and $6>$

\section{S.2 Value chain performance}

- Croatia produces less fruit and vegetables than consumed as fresh products or processed. Even important production crops like onions, watermelons and apples have a self-sufficiency below $100 \%$. Only for mandarins Croatia is more than $200 \%$ self-sufficient. See $\mathbf{2 . 3}>$

- The average size of the farms in Croatia are small compared to many other EU countries. The income per farm working unit for specialist horticulture and fruit orchards lacks behind other producing countries important for the European market. In addition, in comparison to the other EU 
Member States the market share of cooperatives in Croatian agriculture is very low. See $\mathbf{3 . 3}$ and $3.7>$

- This study focuses on seven examples of important fruit and vegetable crops in Croatia: tomatoes, cabbages, onions, garlic, apples, mandarins and sour cherries. With the exception of mandarins and to some extent garlic, Croatian yields are lower than those in most other producing countries important for the European market. Yields of tomatoes, cabbages, onions, apples and sour cherries are considerably lower than in most of the benchmark countries. Small plots that are sometimes more than 10 or 20 kilometres apart, are causing lots of inefficiencies. See $\mathbf{2 . 2 . 4 >}$

- The average profit margin of Croatian fruit and vegetable wholesale fluctuated between -0.4 and $1.6 \%$ between 2012 and 2016, which is average for a European wholesale industry. Nevertheless, in the same five-year period, wholesalers in a range of other competing countries were slightly more profitable, and also seem to have been able to increase their profit margins whereas Croatian wholesalers have not. See $3.4>$

- The supermarket channel is the most important sales channel for fruit and vegetables in Croatia. The emergence of discounter Lidl that follows a cost and price leadership strategy shows that low consumer prices turned out to be a successful retail strategy in Croatia. Foreign retail chains Lidl and Spar are the second and the third largest retailers in Croatia. Domestic market leader Konzum saw its market share decline from $40 \%$ in 2007 to $20 \%$ in 2017 . Eventually, such developments will put more competitive pressure on suppliers, which is especially a threat to smaller Croatian producers who cannot produce and distribute at lowest costs. See $3.6>$

\section{S.3 Method}

The European Bank for Reconstruction and Development (EBRD) has developed a number of projects to improve the performance of the Croatian fruit and vegetables sector in the past. Despite the efforts many fruit and vegetables producers are still struggling to generate enough income to sustain and grow their business. An enhancement of the position of Croatian growers requires a thorough understanding of the interests and performance of all the actors in the value chain as well as of the enabling and supporting environment. See $1.1>$

The EBRD has asked Wageningen Economic Research to carry out a study on the Croatian fruit and vegetables sector and value chain to make a contribution to the enhancement of the position of growers in the value chain for fruits and vegetables. In the study, market opportunities and points of improvement to the value chain and the enabling and supporting environment are defined. In addition, the performance of Croatian producers to competing benchmark countries is compared. The study gives a number of examples and best practices. See $1.2>$

In order to define market opportunities, the study is built upon a three-pillar research method: a desk study to learn about past performance, structural developments and policies; interviews with about 25 actors from the Croatian supply chains of selected products and other stakeholders for studying the latest development and underlying determinants of (lack of) competitiveness, and detecting good practices and opportunities; market attractiveness and business position analysis for detecting interesting market windows in foreign markets. In addition, the preliminary results of the study were presented at the Forum 'Challenges in Development of the Croatian Fruit and Vegetable Sector' organised by EBRD, FAO, the Croatian Ministry of Agriculture, the Chamber of Commerce HGK, and Croatian Young Farmers Association HUMP, in Zagreb on 8 September 2017. Some additional insights from the discussions during the forum are included in the analysis.

See $1.3>$ 


\section{Introduction}

\section{$1.1 \quad$ Background of the study}

In 2013 there were about 157 thousand farm holdings in Croatia on a total of $1.6 \mathrm{~m}$ hectares (Source: Eurostat, ef_m_farmleg). Most of these farms are very small, not exceeding 2 hectares. This applies also to fruit and vegetables production, which represents about $19 \%$ of the total number of farms (including general field cropping). Average income of fruit and vegetables producers is well below that in competing countries, both because of the small relative size of farms as well as because of other structural problems that impact the competitiveness of the sector. The accession into the EU in 2013 has not yet brought the envisaged benefits to Croatian trade, but merely increased competition from other EU countries.

The European Bank for Reconstruction and Development (EBRD) has developed a number of projects to improve the performance of the Croatian fruit and vegetables sector in the past. For example, the EBRD supported mandarin growers from Neretva valley to obtain an EU Protected Geographical Indication (PGI) quality label in 2013. Despite the efforts many fruit and vegetables producers are still struggling to generate enough income to sustain and grow their business. The number of growers is decreasing and the value of production of fruit and vegetables has decreased considerably compared to the period 2005-2010; although some of this decrease can be explained by some exceptionally bad harvests in recent years. A structural change in the Croatian fruit and vegetables sector is needed to turn the tide.

An enhancement of the position of Croatian growers requires a thorough understanding of the interests and performance of all the actors in the value chain as well as of the enabling (e.g. credit, infrastructure) and supporting environment (e.g. policies). It is thought that if the general functioning of the supply chain and the agricultural innovation system including the enabling and supporting environment are improved, adoption of new technologies and positive spill-overs to the competitiveness of the agricultural sector are expected.

\subsection{Goal}

The EBRD has asked Wageningen Economic Research to carry out a study on the Croatian fruit and vegetables sector and value chain. The main objective of this study is to make a contribution to the enhancement of the position of growers in the value chain for fruits and vegetables by defining market opportunities and points of improvement to the value chain and the enabling and supporting environment. By comparing the performance of Croatian producers to competing benchmark countries and by sharing examples and best practices - e.g. from the Dutch agricultural sector and innovation system - the study must contribute to support private sector growth, innovation and development, and foster business model innovation in the Croatian fruit and vegetables sector.

\subsection{Method}

To define market opportunities, the study is built upon a three-pillar research method:

\section{- Desk study}

To learn about past performance, structural developments and policies, literature and public data sources were studied. We used publically available data sources such as Eurostat FADN data to look at developments in farmers' incomes, production volumes and areas, and studied a number of policy reports and academic papers. 


\section{- Interviews}

Interviews were conducted with about 25 actors from the Croatian supply chains of selected products and other stakeholders to study the latest development and underlying determinants of competitiveness or lack of competitiveness, and detect good practices and opportunities. The analysis framework used was adapted from the structure - conduct - performance framework and the SWOT analysis. See Appendix 5 for the list of interviewees.

- MABA analysis (market attractiveness and business position analysis)

To detect interesting market windows in foreign markets for a number of important fruit and vegetables products, we used worldwide trade data from UN Comtrade for the period 2005-2015 to calculate 5 indicators (market SIZE, GROWTH, PRICE, STABILITY, and CONCENTRATION) to determine the countries' market attractiveness for the specific products and 3 indicators (Croatia position on the foreign market in terms of SIZE, MARKET SHARE, and PRICE) to determine Croatia's business position. Those markets that are most attractive and/or where Croatia already has a position as an exporter are listed as the most interesting market windows. See chapter 6 and Appendix 3 and 4 for more details on the methodology. The selection of products and benchmark countries is described in Appendix 1 and 2.

The preliminary results of the study were presented at the Forum 'Challenges in Development of the Croatian Fruit and Vegetable Sector', organised by EBRD, FAO, the Croatian Ministry of Agriculture, the Chamber of Commerce HGK, and Croatian Young Farmers Association HUMP, in Zagreb on 8 September 2017. Some additional insights from the discussions during the forum are included in the analysis.

A general comment on the data and calculations is needed. Although the various sources generally show the same trends in production, area, prices and trade statistics, some significant differences do exist. These differences stem mainly from the use of different definitions and data collection and estimation methods. Also, the variability in production and prices is quite large for most products. Taking one or the other year as a reference year may cause substantial changes in the reported growth rates. Therefore, generally two or three-year period averages have been used when comparing production statistics over time. Between the time of data extraction e.g. from FAOSTAT in May 2017 and the time of publishing of this report, there was a substantial update of the FAOSTAT data regarding production of fruit and vegetables which caused some major changes in de reported volumes of production, which brings them more in line with the volumes reported by the Croatian Bureau of Statistics. Generally the reported volumes are smaller, while the reported areas of production remained unchanged. In the analysis below the most recent data are used to illustrate the production volumes, areas and yields in Croatia. However, in the selection of products and benchmark countries which was done at the beginning of the project the old data were used.

\subsection{Report outline}

In Chapter 2, the Croatian production and trade of fruit and vegetables are described with specific attention to the yields of the seven selected products compared to the benchmark countries. The selected products are tomatoes, cabbages, onions, garlic, apples, mandarins and sour cherries. Chapter 3 focuses on the structure and performance of the various actors in the Croatian fruit and vegetables supply chain. In Chapter 4 the factors in the business environment are described and analysed. Chapter 5 presents the results of the market attractiveness - business position analysis interesting foreign market windows for Croatian produce. Chapter 6 presents the revealed opportunities and some good examples. Finally, Chapter 7 summarises the conclusions and recommendations. 


\section{$2 \quad$ Production and trade}

\section{$2.1 \quad$ Introduction}

Before going into the analysis of the functioning of the value chain, the production and international trade of fruit and vegetables in Croatia are described in this chapter. The analysis is meant to sketch a general picture of the size and growth of the fruit and vegetables sector and the importance of international markets. The focus of the analysis is on a number of selected products. These seven products were chosen on basis of three criteria:

- production volume as an indicator of importance of the product for Croatian growers,

- growth of production as an indicator of current market potential,

- and relative importance of the product for consumption in Croatia.

From the top-ranking product groups - in consultation with experts on the Croatian fruit and vegetables sector - four vegetables and three fruit products were selected: tomatoes, cabbages, onions, garlic, apples, mandarins and sour cherries. The selection of products is explained in Appendix 1.

\subsection{Area, volume, value and yields}

\subsubsection{Cultivated area fluctuates}

The total production area for vegetables in Croatia was 9,618 ha in 2016, while fruit (excluding melons, and excluding grapes and olives) was produced on 29,452 ha. Citrus fruit was cultivated on 2,192 ha in 2016 (Croatian Bureau of Statistics). After a period of decrease between 2009 and $2013 / 2014$, the cultivated area of vegetables and fruit has been increasing again in recent years. The drop in especially the vegetables production area in 2010 is exceptionally large and is apparent in many different vegetables products, including cabbages, tomatoes and onions. The drop is most probably explained by bad weather conditions. The areas of vegetables refer to actually harvested areas. In some years crops were damaged by exceptional rainfall or temperatures and some produce was not harvested.

Another explanation for changes in the areas is that the data collection method of the farm structure survey has changed. Croatia performed farm structure surveys according to the EU legislation in 2007, 2010 and 2013. Not all holdings were surveyed, but rather a sample of producers. However, most of the changes such as the way that used common lands are included, would lead to an increase of areas between 2007 and 2010, and not a decrease. There is no size threshold for market producers of vegetables to be included in the survey, and the threshold for orchards decreased from 0.15 to 0.1 ha between the two censuses in 2007 and 2010.

The period prior to Croatian EU accession in 2013 also caused increased competition from EU imports, which in its turn caused price pressure and may have induced some decreases in land areas too. Additionally, a switch towards increased greenhouse production for some (fruity) vegetables like peppers and tomatoes is observed. However, the area of vegetables cultivated under glass or high accessible cover fluctuated between 2005 and 2016 and was less than 100 ha for the four discerned crops tomatoes ( $98 \mathrm{ha}$ ), red peppers ( $87 \mathrm{ha}$ ), cucumbers (47 ha) and lettuces (13 ha) in 2016 . This increase should not have influenced the total areas of vegetables very much.

Major fruit crops in terms of area are hazelnuts and walnuts (a combined $26 \%$ of the fruit and nuts area excluding grapes and olives in 2016), apples (17\%), plums (14\%), cherries (10\%) and mandarins $(6 \%)$. Cherries, including sour cherries, are the third major fruit crop. Sour cherries 
cultivation ( $72 \%$ of the total area of cherries in 2016) is growing in terms of cultivated area and production volume. The most important vegetable crops in terms of acreage are red peppers (12\%), cabbages $(11 \%)$ and onions and garlic $(10 \%)$. Tomatoes accounted for $3.2 \%$ of the total area of vegetables.

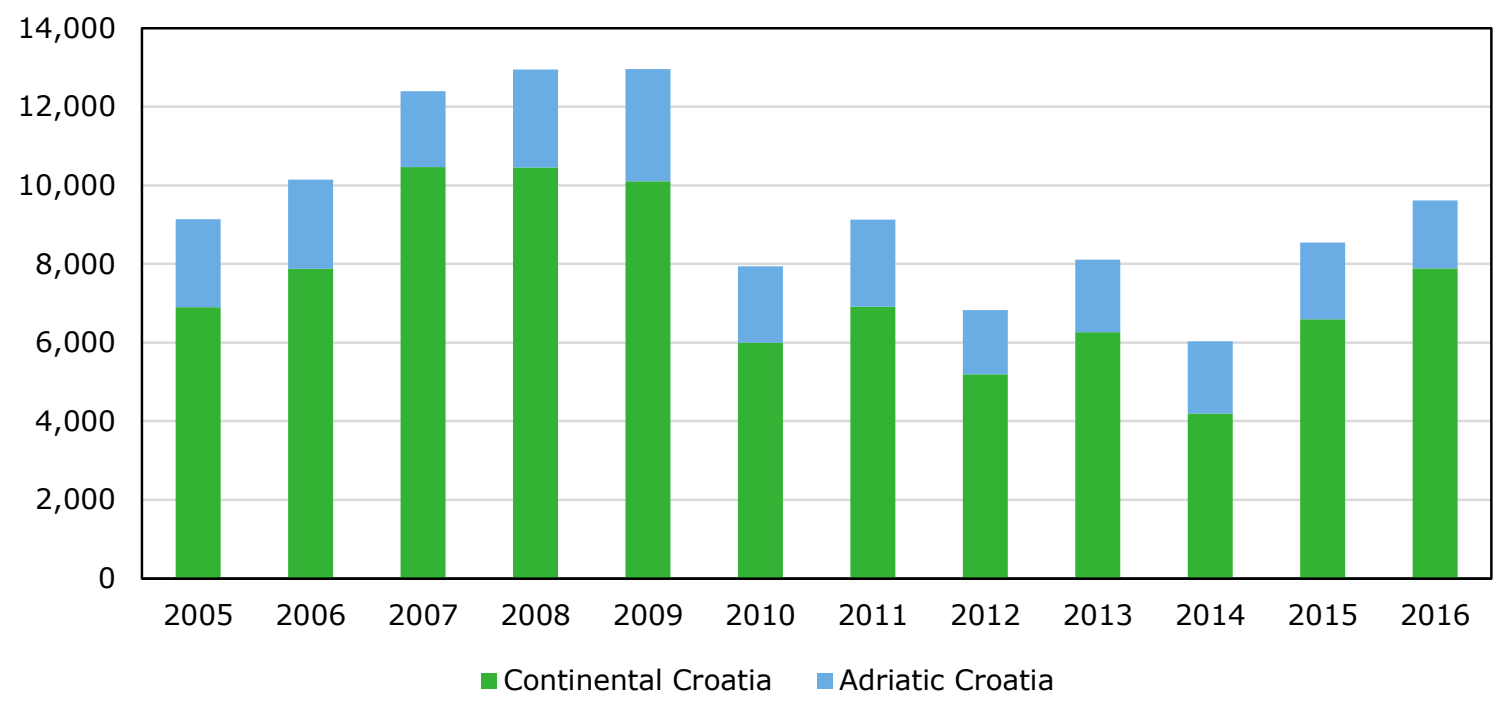

Figure 2.1 Area harvested of vegetables in Croatia by region, 2005-2016, in hectares Source: Croatian Bureau of Statistics.

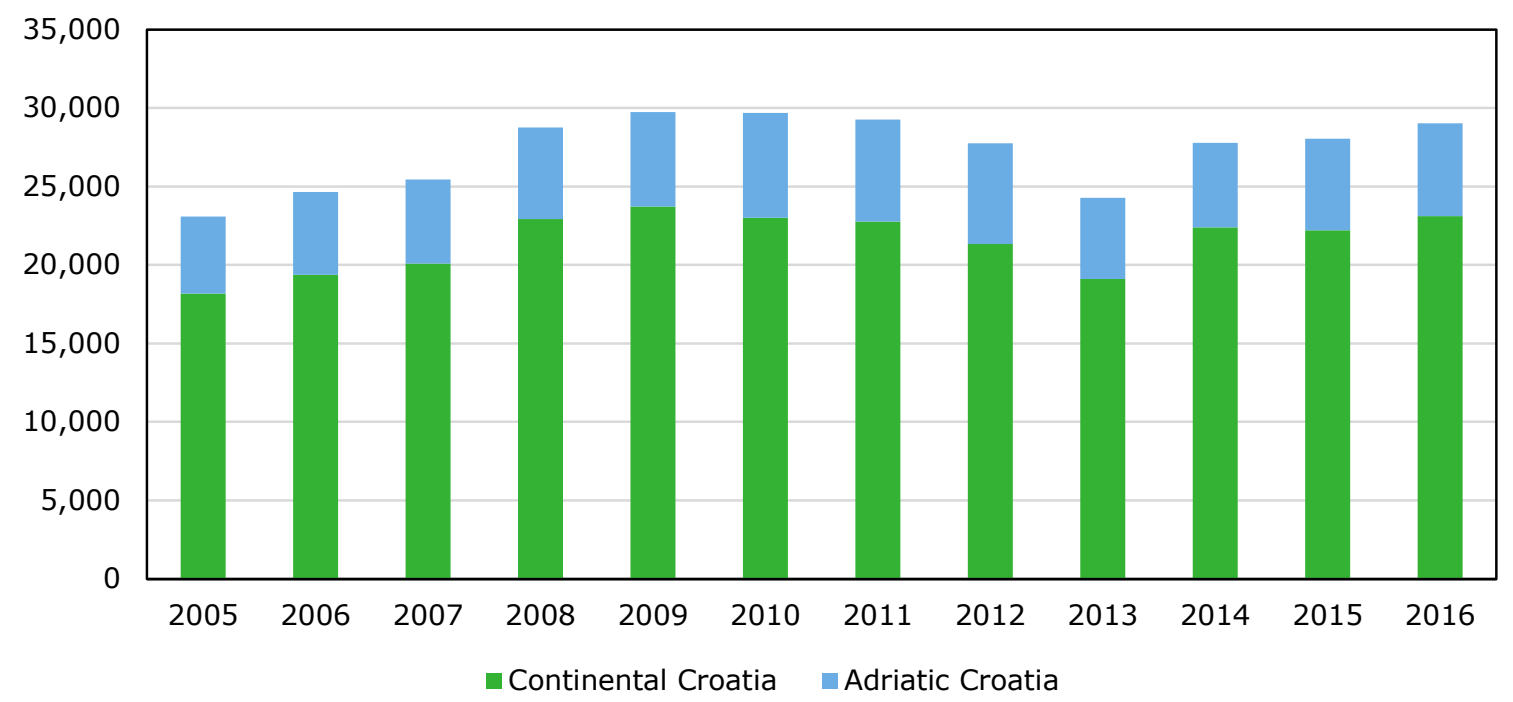

Figure 2.2 Area of fruit and nuts (excluding melons, grapes and olives) in Croatia by region, 20052016, in hectares

Source: Croatian Bureau of Statistics. 


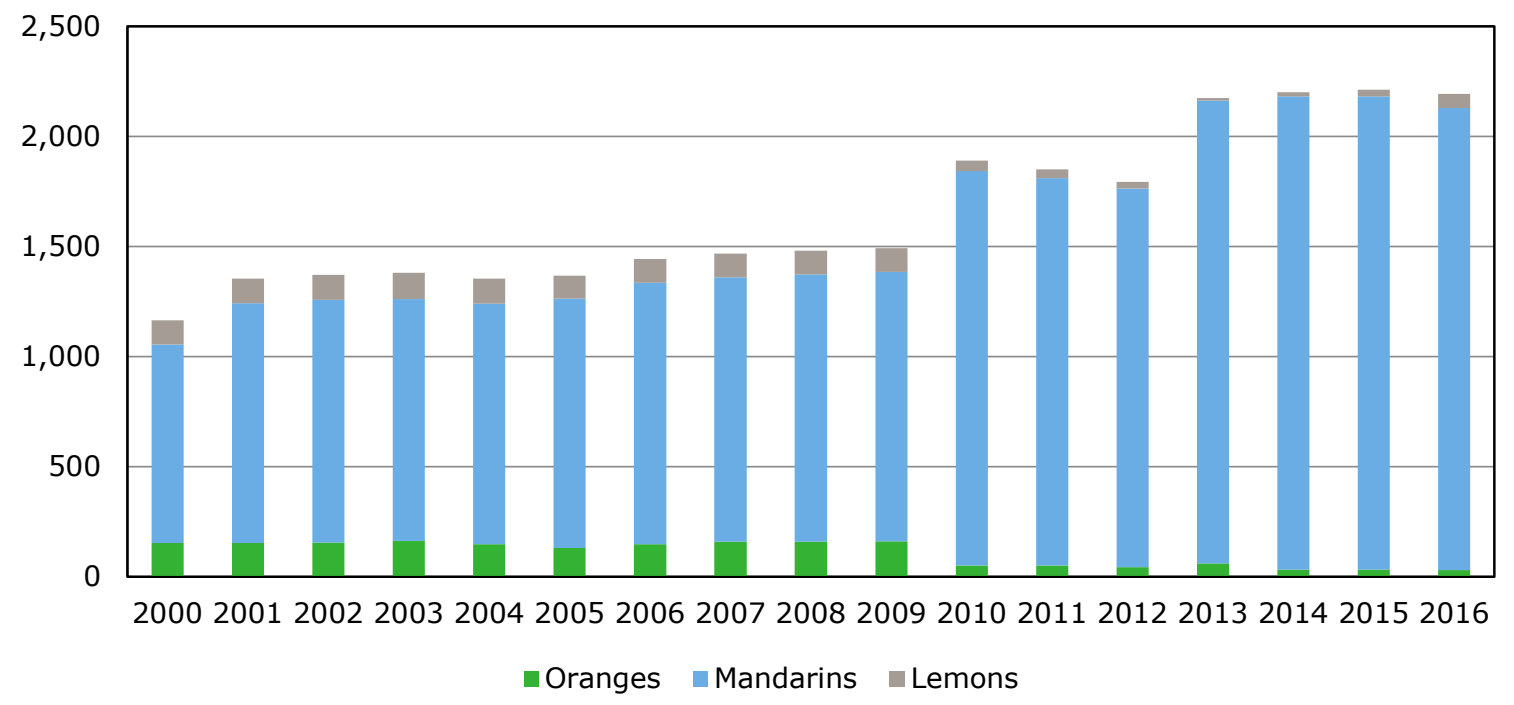

Figure 2.3 Area of citrus fruit orchards Croatia, 2000-2016, in hectares Source: Croatian Bureau of Statistics.

According to FAO (FAO, 2008), ${ }^{1}$ there have been changes in the diversity of agricultural crops grown in the country in the period prior to EU accession. New stricter market rules were adopted, which led to the decline of the number of old Croatian cultivars and had some negative effects on the diversity of crops. Currently, in the commercial production of fruit and vegetables only certified seeds are used. Still, there are some strong landraces of vegetables that are important in the Croatian agriculture, for example in beans, cabbage, and garlic. Landraces are a domesticated, locally adapted, traditional varieties of crops cultivated in a certain level of isolation from other crop populations. For six out of seven of our focus crops, there are some important particularities to be mentioned in this perspective, such as:

\section{- Tomatoes}

The varieties of tomatoes for processing grown in Istria are distinguishable by a particular quality needed for processing. Breeding programmes are applied to develop these varieties in a collaboration between growers, the processing industry and research institutions.

\section{- Cabbages}

For cabbages, in addition to a wide range of varieties known in Europe, including red and white cabbages, there are landraces that are especially grown for fermentation, of which some according to the traditional methods. Ogulin and Varaždin sour cabbages received EU protected designation of origin in respectively August 2015 and October 2017.

\section{- Garlic}

Croatian garlic is a landrace, which is a fragrant variety with strong flavour which differs from garlic from China as the main supplier to Europe. Croatian consumers widely use this variety in traditional Croatian dishes.

\section{- Apples}

Although there are some native apple varieties such as Slavonska srčika, growers plant their orchard predominantly with commercial varieties widely known in Europe, such as Golden and Red Delicious, Granny Smith, Jonagold, Fuji, Gala, etc.

\section{- Mandarins}

Mandarins grown in Croatia, predominantly in the Neretva valley, are satsuma mandarins and are known by their early maturation and good fruit quality than other Mediterranean cultivars. ${ }^{2}$ The Neretva satsumas have received EU protected designation of origin.

\footnotetext{
1 http://www.fao.org/docrep/013/i1500e/Croatia.pdf

2 https://www.researchgate.net/profile/Tomislav_Jemric2/publication/230785833_Fruit_quality_of_Satsuma_mandarin_in_ Croatia_-_problems_and_perspectives/links/02e7e533d8793bb8f1000000/Fruit-quality-of-Satsuma-mandarin-in-Croatiaproblems-and-perspectives.pdf
} 


\section{- Sour cherries}

Croatian sour cherries include the so-called Maraska variety, which is indigenous to and widely cultivated in Dalmatia. Maraska has a strong aroma and an excellent quality of fruit of particular value in the liqueur industry.

\subsubsection{Different production volume developments per crop}

Croatian production of vegetables (including melons) was about 191 thousand tonnes in 2016.

Cabbages, onions and tomatoes are the most important vegetables crops in terms of volume. Fruits, berries and nuts (excluding grapes, olives, melons, and strawberries) production was estimated at about 129 thousand tonnes in 2016. Mandarins and apples account for the largest part of fruit production.

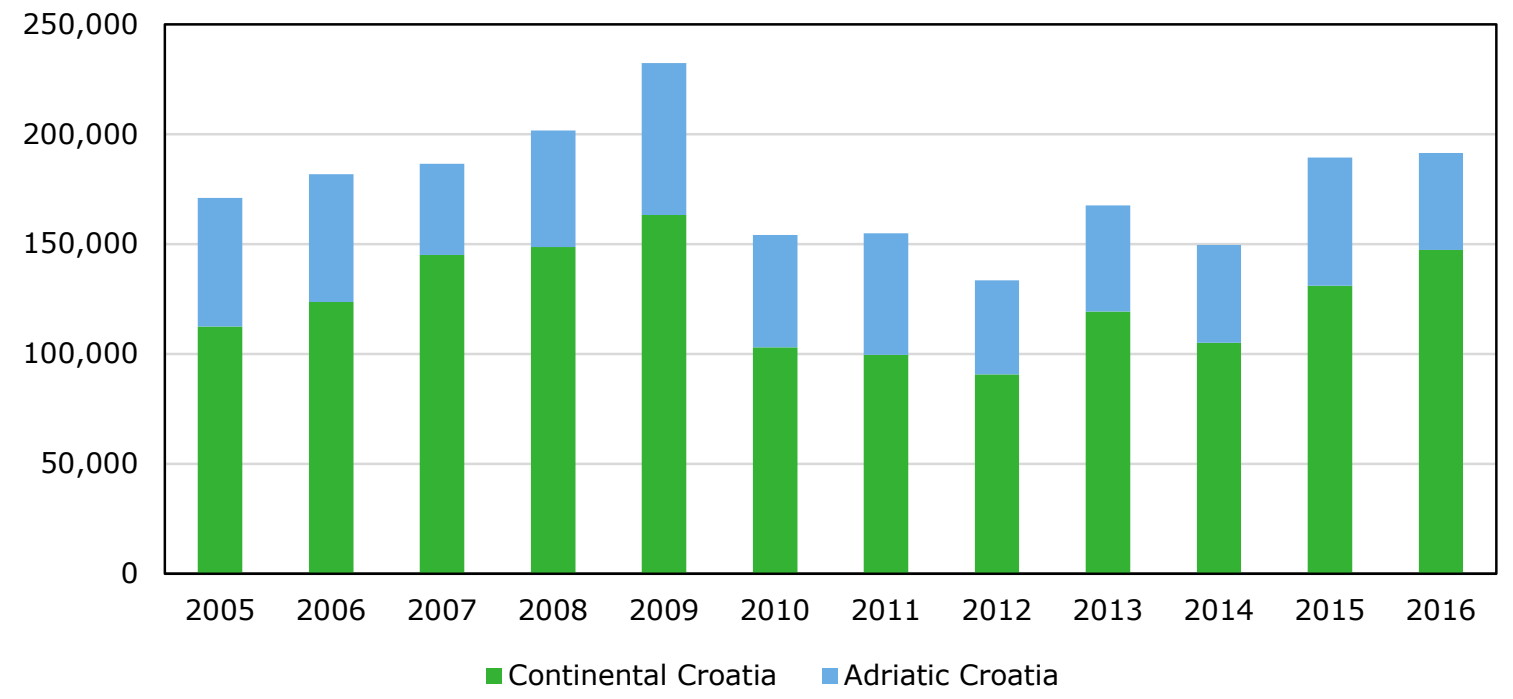

Figure 2.4 Production volume of vegetables (including melons) in Croatia, per region, 2005-2016, in tonnes

Source: Croatian Bureau of Statistics.

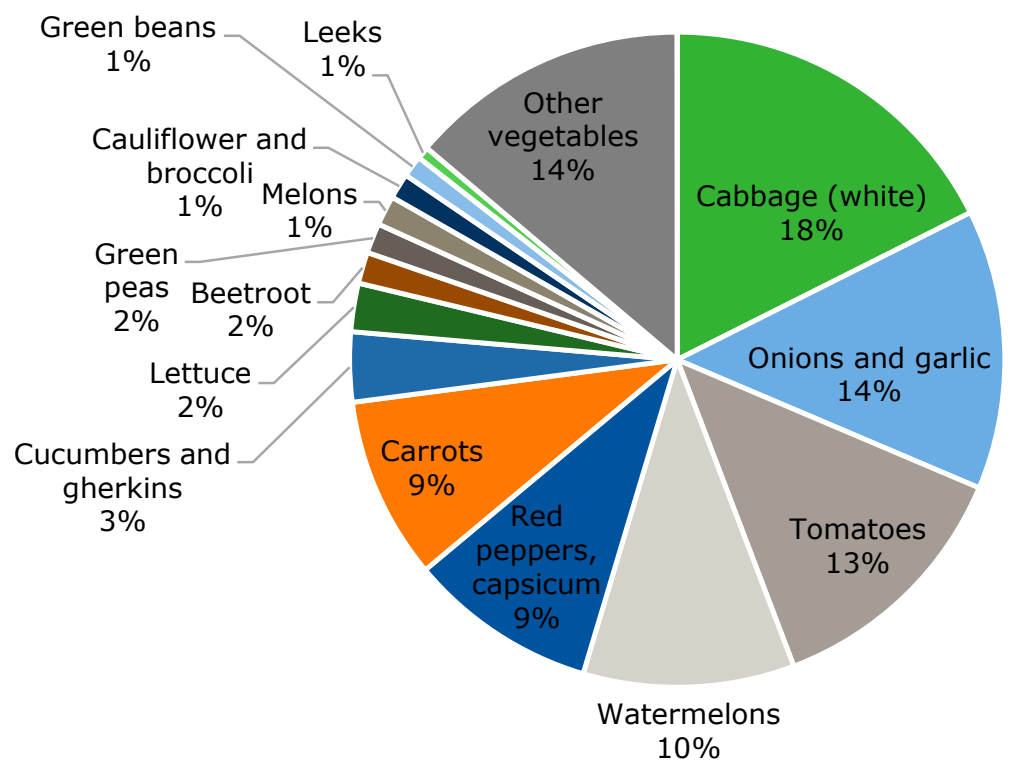

Figure 2.5 Division of the production volume of vegetables (including melons) in Croatia, in 2016, in \%

Source: Croatian Bureau of Statistics. 


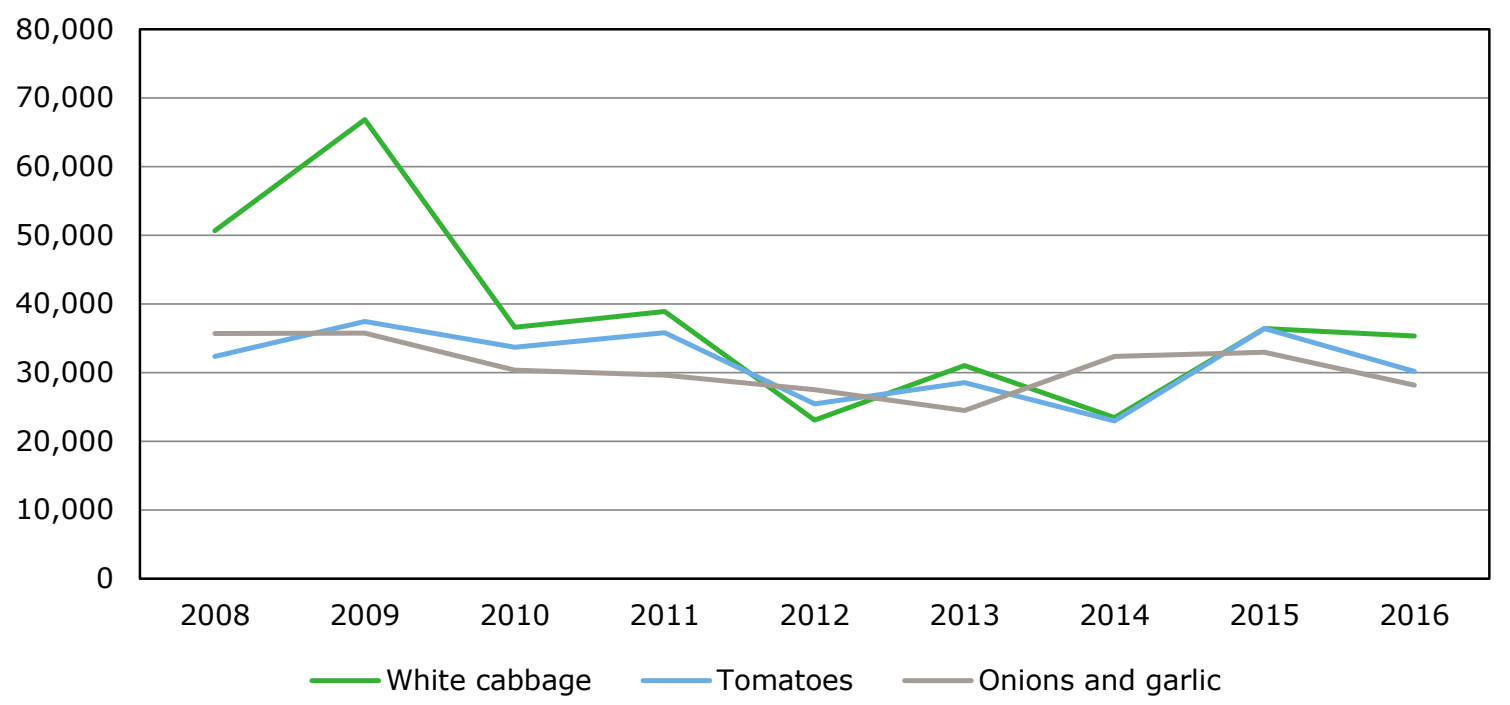

Figure 2.6 Production volume of white cabbage, tomatoes, and onions and garlic in Croatia, 20052016, in tonnes

Source: Croatian Bureau of Statistics.

For fruit the picture is somewhat different than for the vegetables. The total area of fruit production also decreased, but production volumes actually increased due to an increase in the production of particularly apples, mandarins, and sour cherries. Production volumes of some fruit crops like apples show extreme fluctuations. The harvest of apples fell to less than half of normal production in 2012, and again fell to 44 thousand tonnes in 2016 according to Eurostat. The area and production of plums and sloes decreased significantly over the past decade.

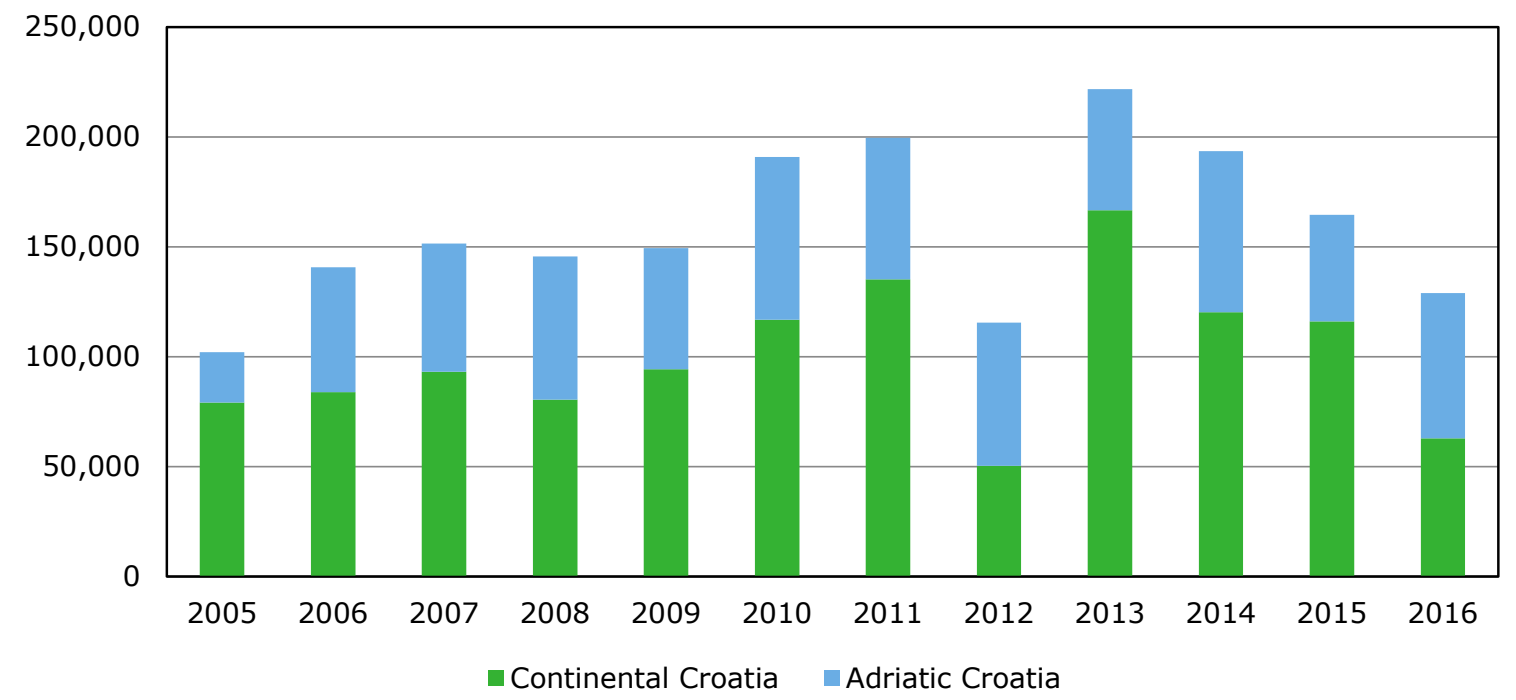

Figure 2.7 Production volume of fruit and nuts in Croatia, per region, 2005-2016, in tonnes Source: Croatian Bureau of Statistics. 


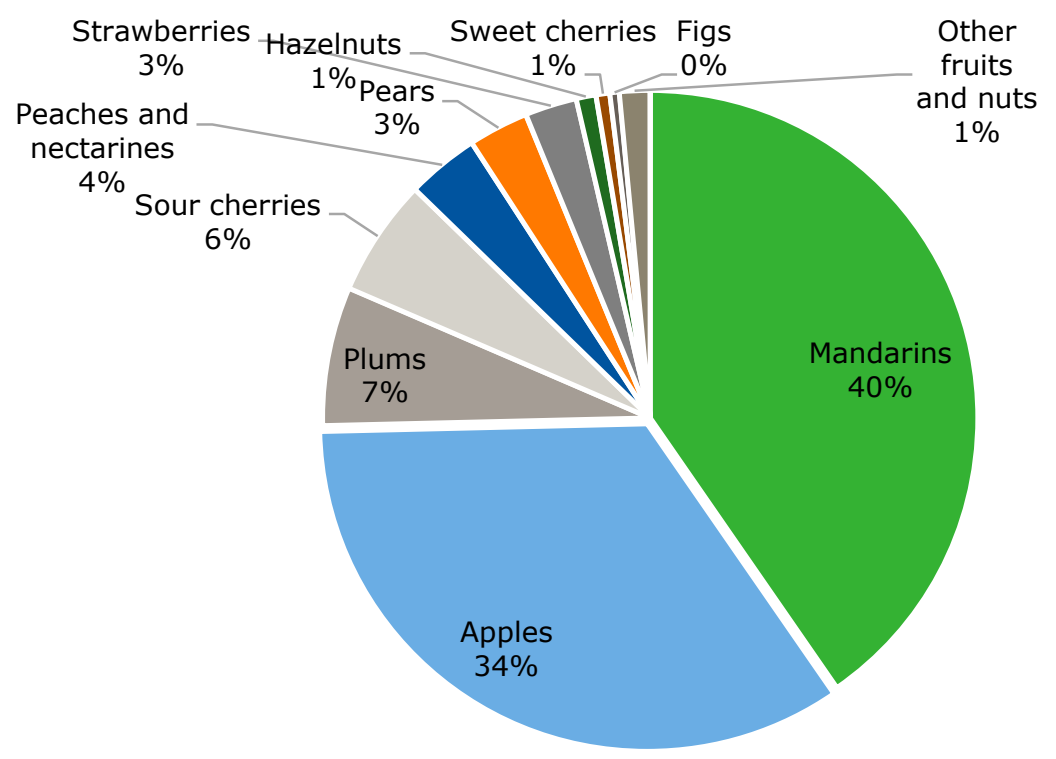

Figure 2.8 Division of the production volume of fruit and nuts in Croatia, in 2016, in \% Source: Croatian Bureau of Statistics.

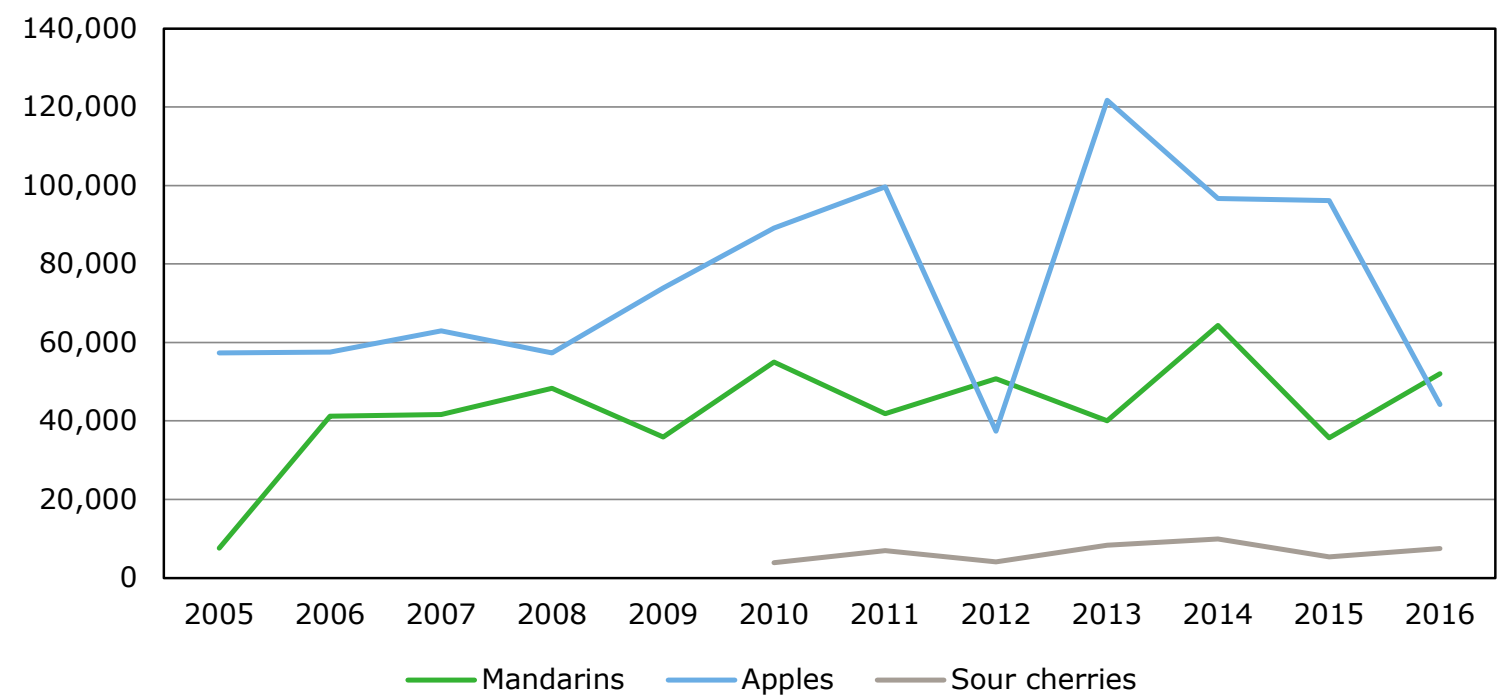

Figure 2.9 Production volume of mandarins, apples and sour cherries in Croatia, 2005-2016, in tonnes

Source: Croatian Bureau of Statistics.

\subsubsection{Most production value from fresh vegetables}

The total production value of fresh fruit and vegetables (potatoes, grapes and olives excluded) in Croatia is estimated at $€ 126 \mathrm{~m}$ ( $950 \mathrm{~m}$ Kuna) in 2016 (on the basis of Eurostat data which are similar to the data provided by the Croatian Bureau of Statistics). After a period of growth of the production value between 2005 and 2009 from $€ 161 \mathrm{~m}$ to $€ 245 \mathrm{~m}$, total production value gradually fell after 2009 until 2012 and has fluctuated around $€ 125 \mathrm{~m}$ since. About $€ 84 \mathrm{~m}$ relates to fresh vegetables in 2016 , of which 20 to $30 \%$ were tomatoes. The remaining $€ 41 \mathrm{~m}$ was covered by fruit production, of which about $€ 12 \mathrm{~m}$ consisted of citrus fruit.

The production value of the most important fruit crop, apples, fluctuated between $€ 20 \mathrm{~m}$ and $€ 40 \mathrm{~m}$, and 2016 was an exceptionally bad year with a total production value of just $€ 17 \mathrm{~m}$. The value of the citrus fruit (mandarins mainly) harvest was also quite low in 2016, at $€ 12 \mathrm{~m}$. Preliminary data for 2017 indicate a growth of production value compared to 2016 for vegetables and fruits, and especially citrus fruits. 


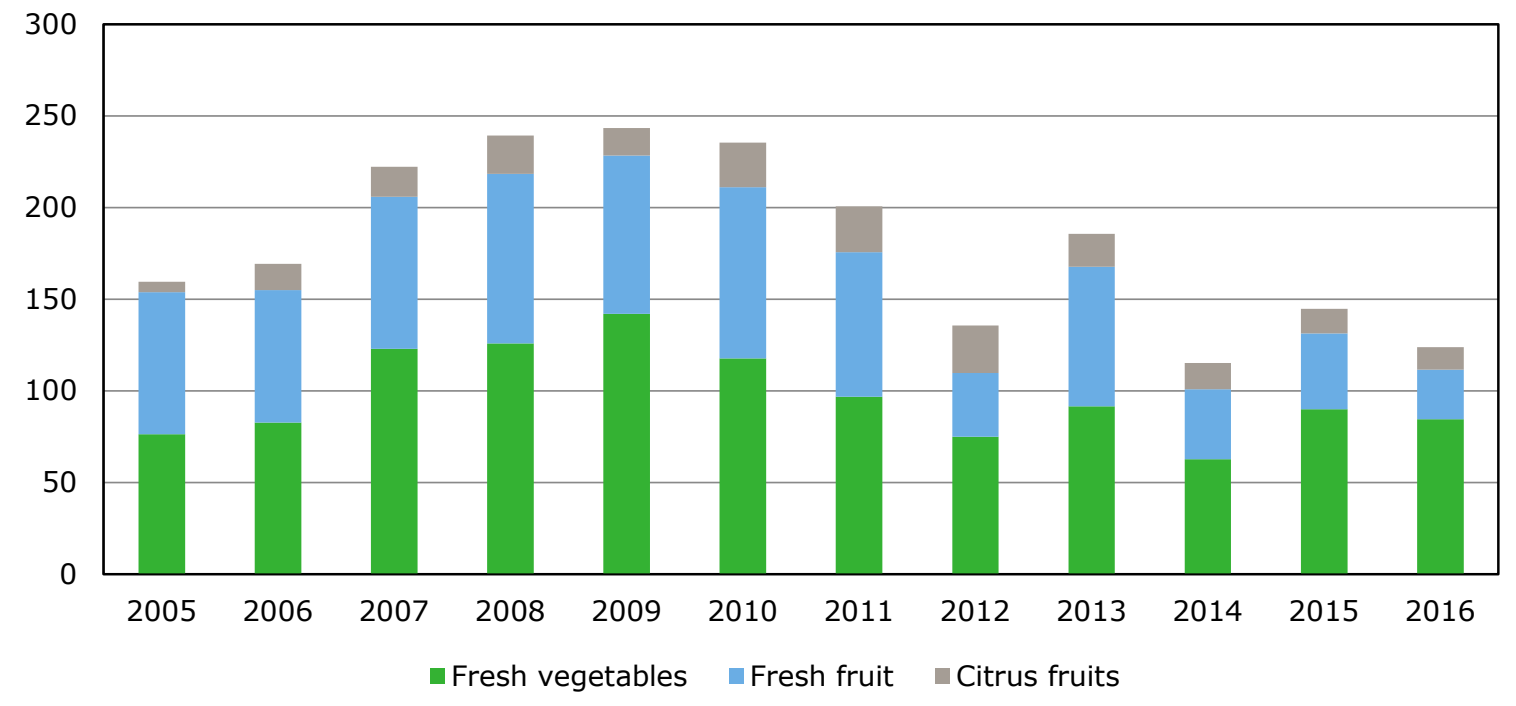

Figure 2.10 Production value at basic prices of vegetables and fruit in Croatia, 2005-2016, in €m Source: Eurostat, Economic accounts for agriculture - values at current prices [aact_eaa01].

At the same time the unit value of Croatian production gradually decreased. This was caused partly because some of the crops with the highest growth in production volume were crops with relatively low prices per kilogram, such as onions, mandarins and sour cherries as opposed to sweet cherries.

\subsubsection{Production efficiency: yields}

High production efficiency is an important indicator of good farm management. One of the problems associated with the small average scale of Croatian farms (see also Chapter 4.3.) is a relatively low production efficiency. Small plots that are sometimes more than 10 or 20 kilometres apart, are causing lots of inefficiencies. First, the time needed for traveling is a source of inefficiency. Second, irrigation systems have to be constructed and often growers have to drill water wells on every separated plot of land. Third, it is less efficient to use conventional agricultural machinery for field preparation, fertilising, sowing, and harvesting on smaller plots. The charts below show the average yield in tonnes per hectare for the seven focus products in Croatia and the selected benchmark countries (see Appendix 2 for the selection of the benchmark countries).

Tomatoes

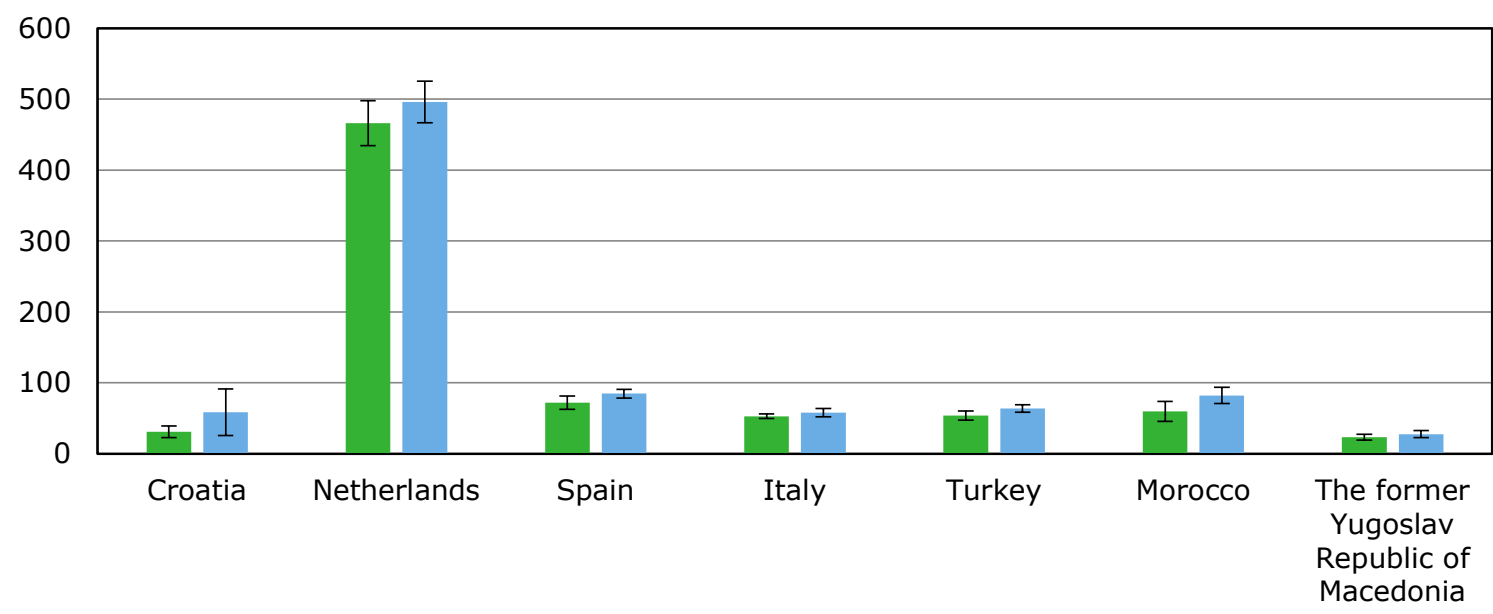

average 2005-2009 average 2012-2016

Figure 2.11 Yields of tomatoes, in tonnes per hectare, 2005-2009 and 2012-2016, for Croatia and selected benchmark countries. Error bars of two standard deviations (95\% CI) over the same periods Source: FAOSTAT, data extracted on 22 December 2017, calculations Wageningen Economic Research. 
Cabbages and other brassicas

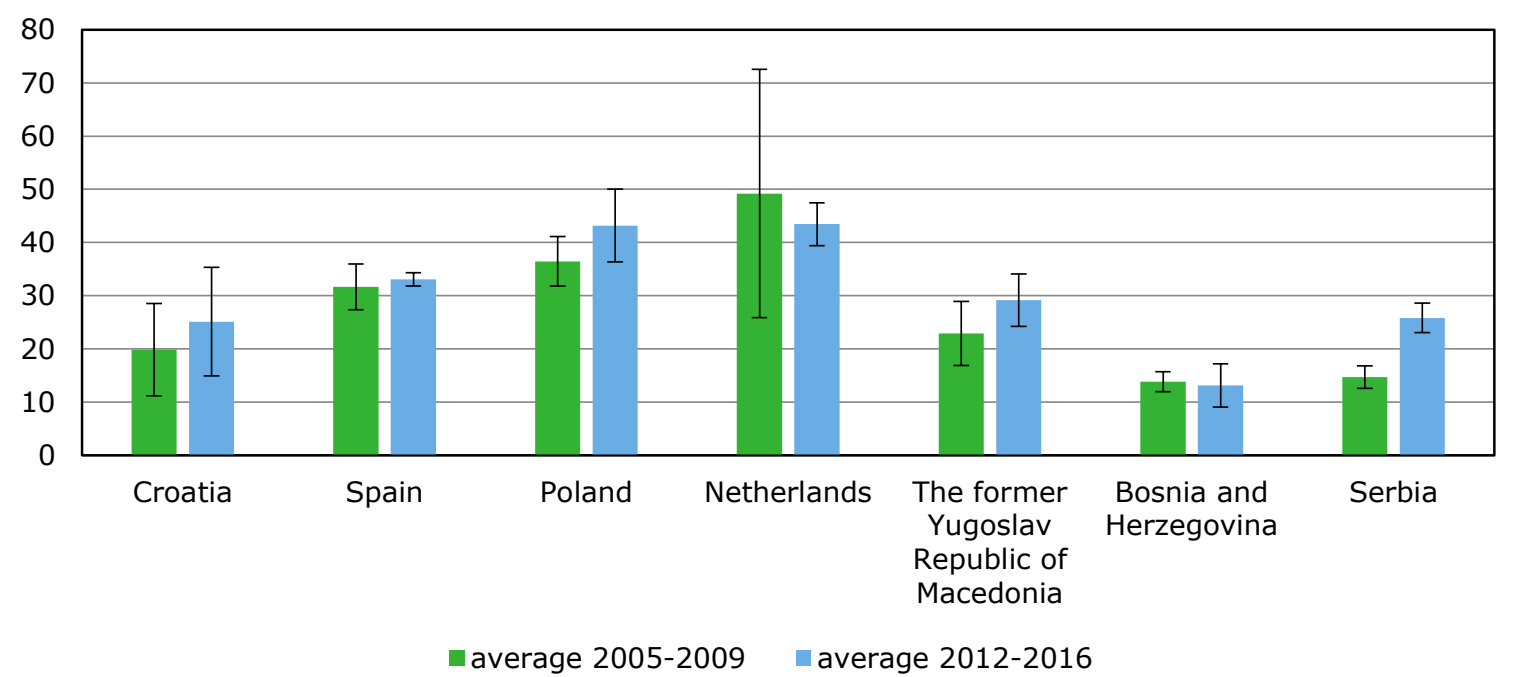

Figure 2.12 Yields of cabbages and other brassicas, in tonnes per hectare, 2005-2009 and 20122016, for Croatia and selected benchmark countries. Error bars of two standard deviations (95\% CI) over the same periods

Source: FAOSTAT, data extracted on 22 December 2017, calculations Wageningen Economic Research.

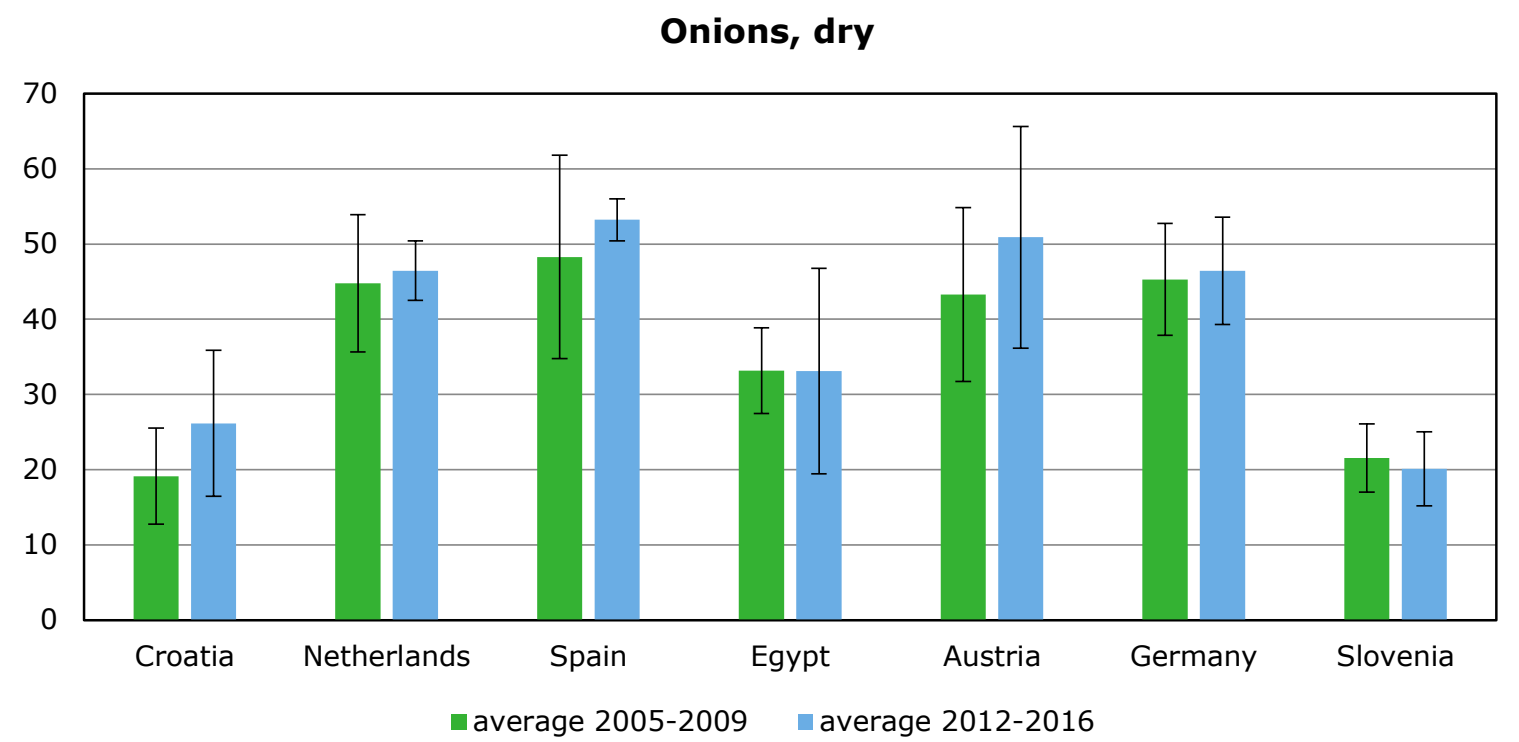

Figure 2.13 Yields of onions, in tonnes per hectare, 2005-2009 and 2012-2016, for Croatia and selected benchmark countries. Error bars of two standard deviations (95\% CI) over the same periods Source: FAOSTAT, data extracted on 22 December 2017, calculations Wageningen Economic Research. 


\section{Garlic}

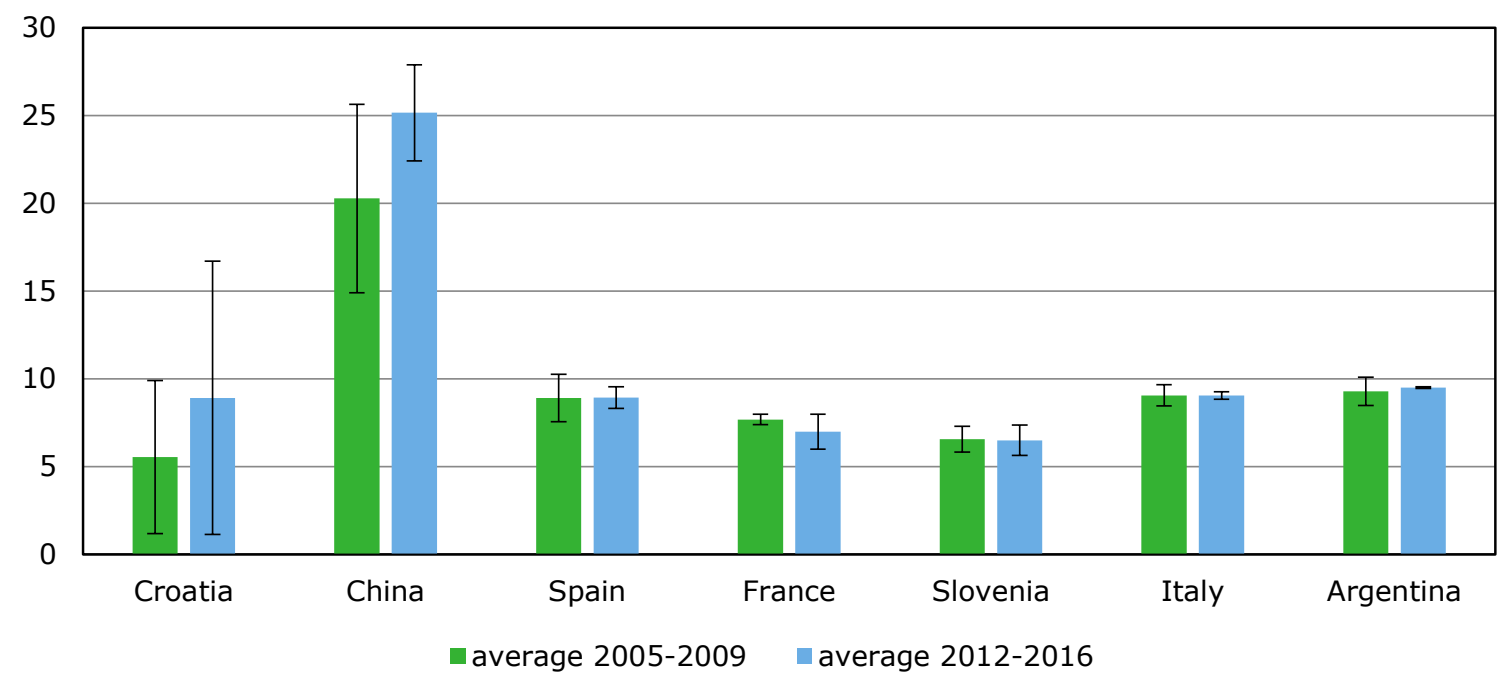

Figure 2.14 Yields of garlic, in tonnes per hectare, 2005-2009 and 2012-2016, for Croatia and selected benchmark countries. Error bars of two standard deviations ( $95 \%$ CI) over the same periods Source: FAOSTAT, data extracted on 22 December 2017, calculations Wageningen Economic Research.

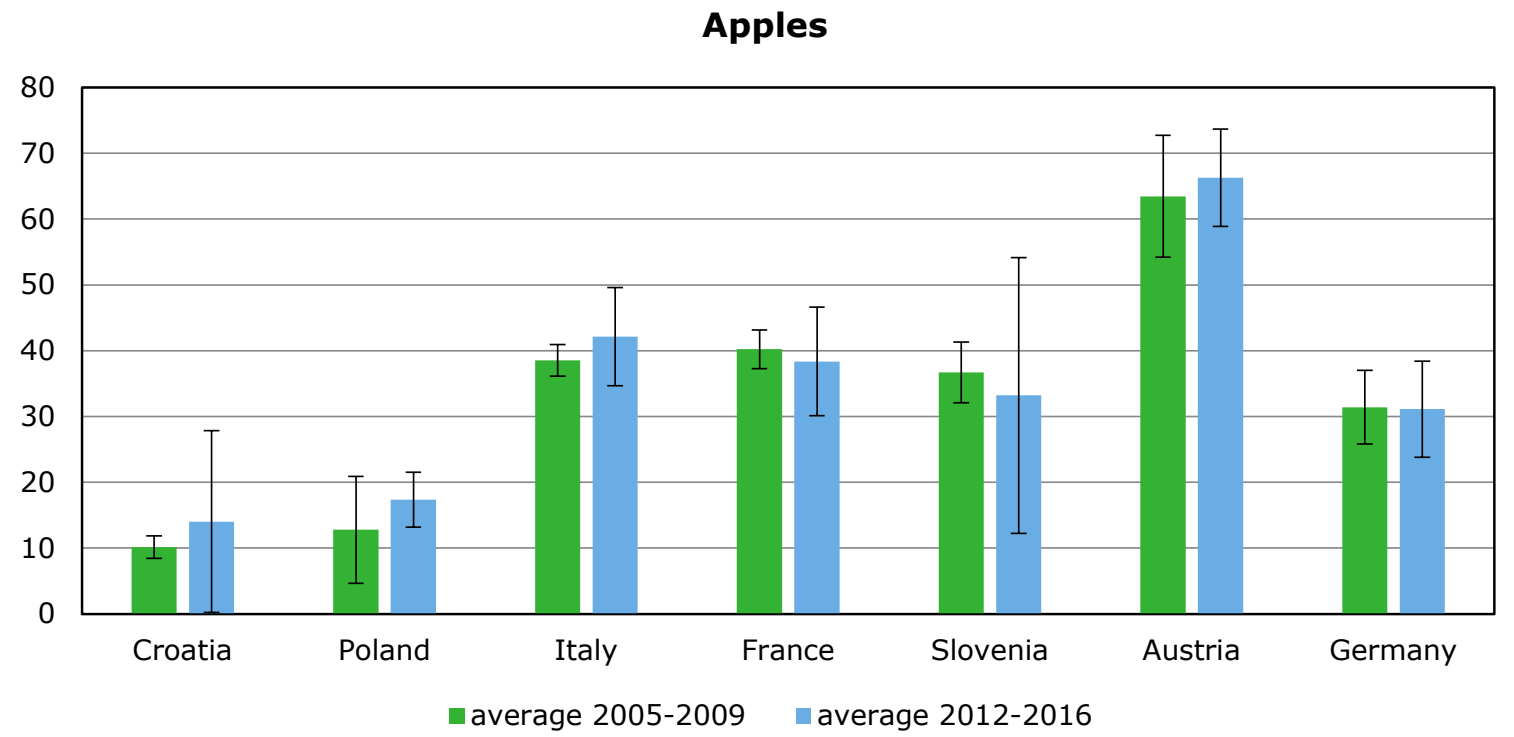

Figure 2.15 Yields of apples, in tonnes per hectare, 2005-2009 and 2012-2016, for Croatia and selected benchmark countries. Error bars of two standard deviations (95\% CI) over the same periods. Austria is 2010-2014 data as new data on acreage and yield is not available after FAOSTAT update Source: FAOSTAT, data extracted on 22 December 2017, data Austria extracted on 8 May 2017, calculations Wageningen Economic Research. 
Mandarins

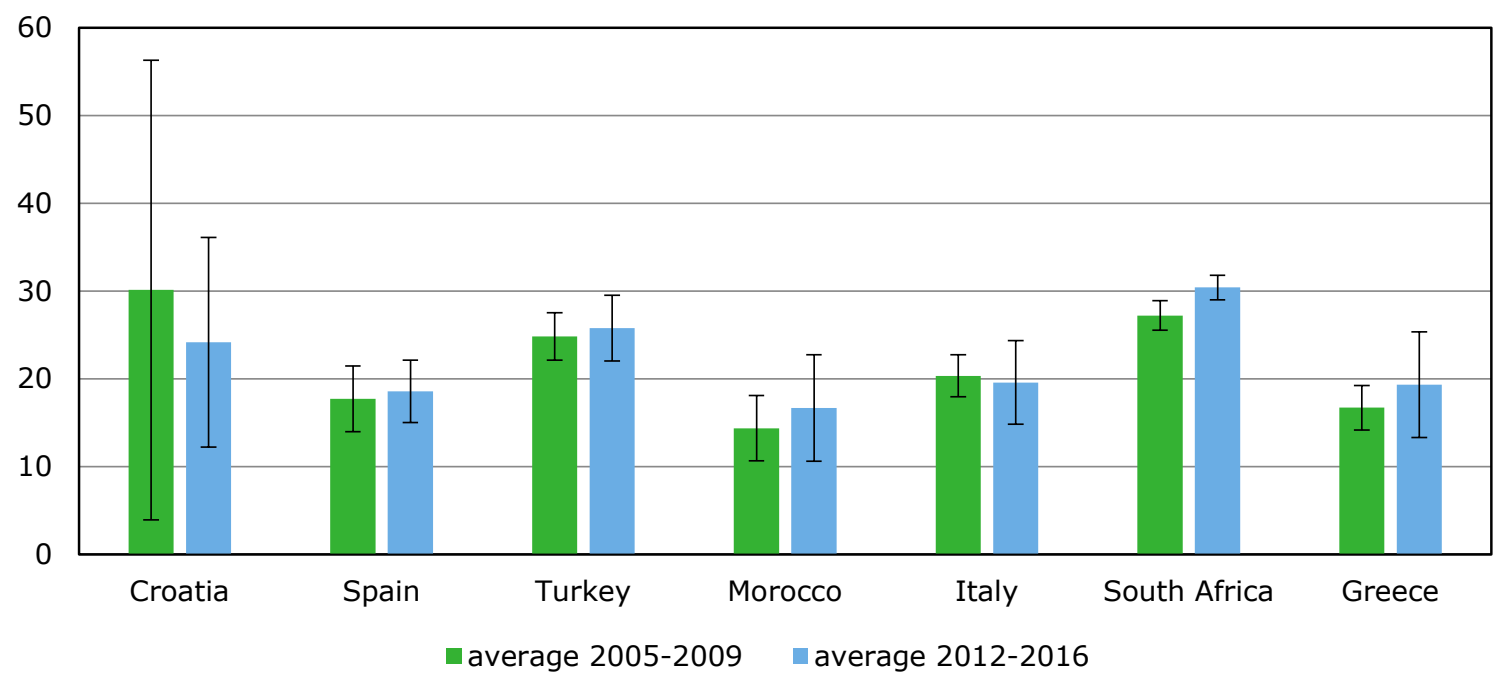

Figure 2.16 Yields of mandarins, in tonnes per hectare, 2005-2009 and 2012-2016, for Croatia and selected benchmark countries. Error bars of two standard deviations (95\% CI) over the same periods Source: FAOSTAT, data extracted on 22 December 2017, calculations Wageningen Economic Research.

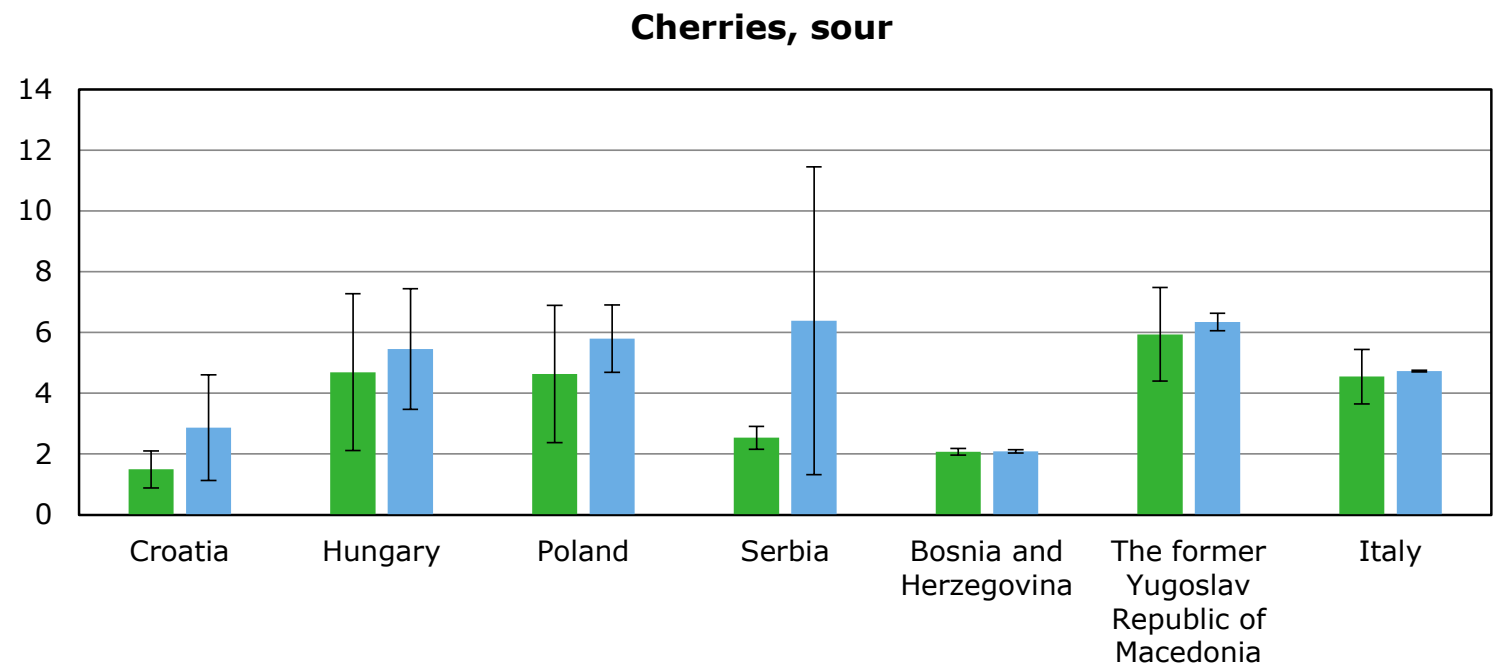

average 2005-2009 average 2012-2016

Figure 2.17 Yields of sour cherries, in tonnes per hectare, 2005-2009 and 2012-2016, for Croatia and selected benchmark countries. Error bars of two standard deviations (95\% CI) over the same periods Source: FAOSTAT, data extracted on 22 December 2017, calculations Wageningen Economic Research.

With the exception of mandarins and to some extent garlic, Croatian yields are lower than those in most benchmark countries. Yields of tomatoes, cabbages, onions, apples and sour cherries are considerably lower than in most of the benchmark countries.

For tomatoes, cabbages, onions, and sour cherries yields were comparable to and sometimes slightly higher than in other former Yugoslavian countries Bosnia and Herzegovina, Slovenia, Serbia and TFYR of Macedonia. Compared to major competing producing countries like Spain, the Netherlands, Poland and Austria, yields are often less than half as much. For tomatoes, a comparison to the Netherlands is 
difficult to make, as in the Netherlands all tomatoes are produced in glasshouses and almost the whole harvest is destined for the fresh market instead of for processing. Nevertheless, the figures show that average yields of vegetables in Croatia may be dramatically improved for most products.

For apples, of the benchmark countries, only Poland reported somewhat comparable yields. Modern apple orchards can reach average yields of around 40-60 tonnes per hectare, while the average for Croatia was 15 tonnes in 2012-2016. In Austria the average even reached 66 tonnes in 2010-2014. ${ }^{3}$ The association of apple producers 'Klaster Slavonska Jabuka' is making great progress in increasing the yields and reports average yields exceeding 55 tonnes per hectare in good years. Production remains however very volatile.

For mandarins and garlic, Croatia is slightly more productive than most of its direct rivals. Only China reported much higher yields for garlic, but as mentioned before, this garlic if of a different type. Garlic yields have also been improving a lot, mainly due to investments in farm management practices.

In addition to actual yields, the variability of annual yields is also an indicator of production efficiency, as it depicts the influence that the farm management has on actual yields. Variability is calculated as the deviations (standard deviation) from the average yield for the periods 2005-2009 and 2012-2016. ${ }^{4}$ In Croatia, yields of tomatoes varied by about 20-30\% around the 2005-2016 average.

In Turkey, the Netherlands, and Italy, yields varied much less, relative to the average yield. For the Netherlands and to a lesser extent Turkey this may not be a surprise because most of the tomato production in these countries is taking place under glasshouses or plastic cover. In Italy and Spain, most tomatoes grow outdoor, only part of the tomato area is covered by glasshouses, but yields in glasshouses are a lot higher than in the open field. Greenhouse production damps weather conditions and this higher control of the circumstances leads to a lower variability. From the charts it becomes clear that the variability of yields is relatively large in Croatia in comparison with the benchmark countries.

In terms of production efficiency there is much to gain in Croatia. Judging from yields and their variability in comparable countries in terms of climate and soil, over time average yields may be improved by at least $30 \%$ to $70 \%$ for tomatoes, cabbages, onions and cherries, while apple yields may be even doubled. Improvements in planting distance, maintenance of the trees, irrigation, crop protection, harvesting methods, and post-harvests handling may also further increase yields for mandarins.

Open field production and bad weather conditions have played a major role; e.g. in 2012 yields of almost all crops have been affected and the harvests of mandarins have been affected in 2015 while the harvest of apples was dramatically low in 2016. Weather always plays an important role in agriculture, but good farm management including irrigation and drainage systems, good planning of sowing and harvesting, crop protection, and protective cover when necessary, will greatly influence the variability of yields as a result of those weather influences.

Other indications of good farm management are post-harvest losses. In general, post-harvest losses are largely influenced by the environmental conditions such as temperature and relative humidity in which products are kept after harvest, which depends on the crop. In Croatia, post-harvest losses were estimated to be around $40 \%$ (Jemrić et al., 2013). For example, in the interviews for this study, the rejected volume of mandarins when delivered to the packing houses (growers not being paid for them) was estimated to be about $10 \%$. This volume consists of mandarins that are spoiled and/or do not meet a certain marketing standard quality. Most of this volume is wasted after rejection. One can conclude that the better the knowledge and quality of farming techniques, post-harvest treatment, and the quality of storage facilities and farm management skills are on a farm, the less negative impact on product quality and value.

\footnotetext{
3 More recent data of acreage and yields of apples were not available for Austria in FAOSTAT at the time of extraction of the data.

4 This means that variability is also larger if yields are increasing or decreasing consistently over the measurement period, as is the case for garlic in Croatia.
} 


\subsection{Below self-sufficiency for most products}

Domestic supply of fruit and vegetables was calculated on the basis of the latest complete data on production and trade from FAOSTAT for 2012 and 2013. Domestic supply is equal to production plus imports minus exports. It is a proxy for domestic uses which includes other uses like processing and waste, next to human consumption. The self-sufficiency level indicates to what extent Croatian production is covering domestic consumption and other uses. The table below shows that Croatia is not self-sufficient for most products. Even important production crops like onions, watermelons and apples have a self-sufficiency below $100 \%$. Only for mandarins Croatia is more than $200 \%$ selfsufficient.

Note that most of the products are only produced during a relatively short season. Tomatoes and most other open field vegetables are produced from March to September. The area of greenhouse production of tomatoes is increasing, which in turn leads to an increased production season. Apples and mandarins are harvested from about mid-September. Apples are kept in cold storage longer than mandarins, hence extending the selling season. The average annual self-sufficiency figures are therefore somewhat distorted by the differences in seasonal patterns. On the other hand, most products are also experiencing seasonal peaks in demand.

Table 2.1 Production, import, export and domestic supply and self-sufficiency (share of production in domestic supply) of fruits and vegetables in Croatia, averages in tonnes for 2015-2016

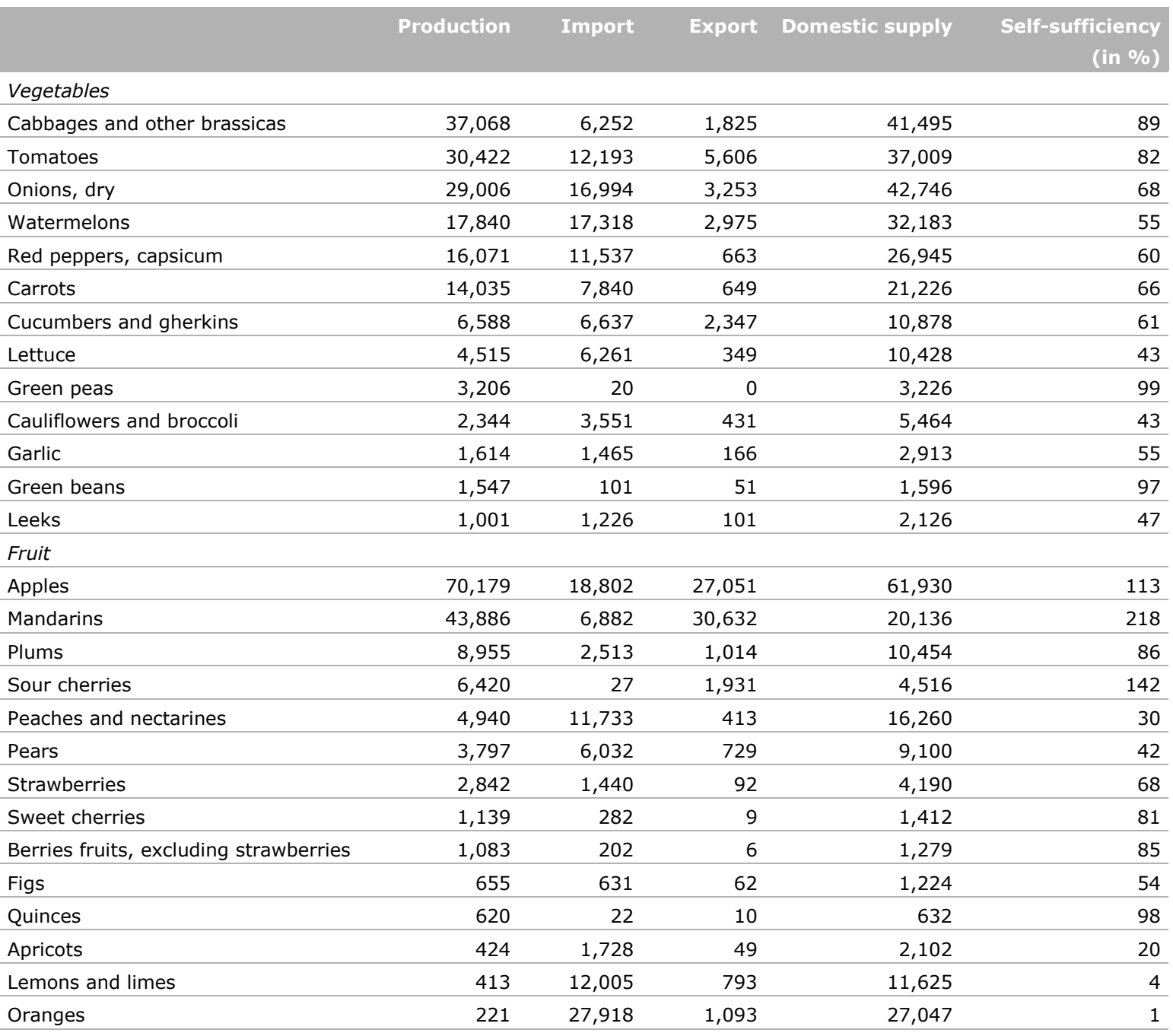

Source: FAOSTAT, COMTRADE, calculations Wageningen Economic Research. 


\section{Value chain analysis}

\subsection{Introduction}

This chapter describes the various actors in the Croatian fruit and vegetables value chain. The structure of the value chain is analysed in terms of numbers and size of actors, activities performed, performance in terms of incomes of growers, profits of wholesalers and markets shares of retailers. Various aspects of the structure, conduct and performance of the supply chain actors are analysed, and recent developments are discussed. The analysis is based on desk study and interviews with 25 actors and stakeholders from various stages of the supply chains of the seven selected products in Croatia.

\subsection{Value chain: from grower to consumer}

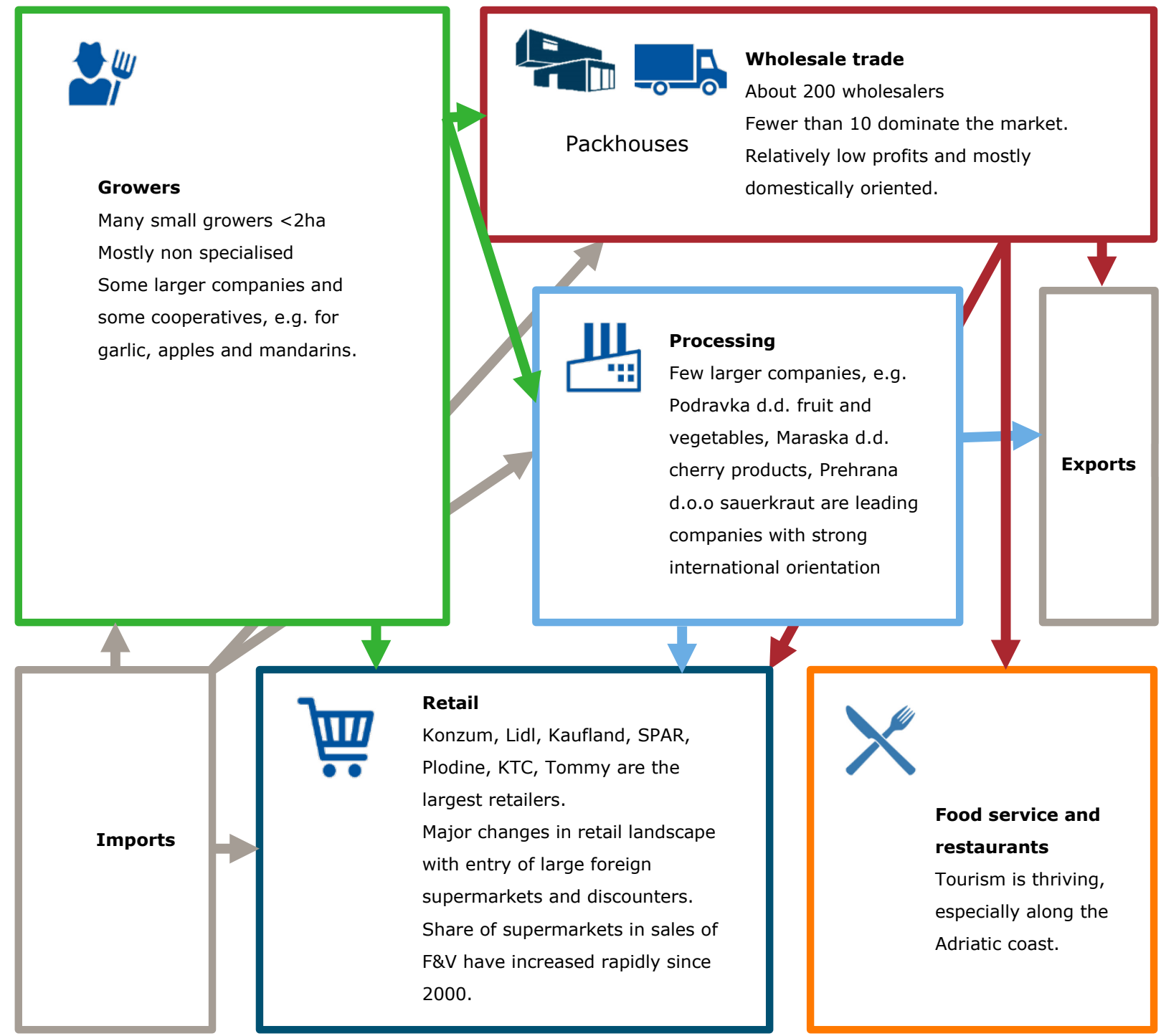

Figure 3.1 Vegetables and fruit supply chain in Croatia 
Figure 3.1 gives a schematic overview of the actors in the Croatia fruit and vegetables supply chain. More information on the numbers of farmers, wholesalers and retailers and their performance is given in subsequent sections. Inputs at farm level are mostly seeds and seedlings, fertilisers, crop protection, and water and energy. The majority of the inputs are sourced from Croatian suppliers. Some companies have indicated to import e.g. seeds from the Netherlands. But for many products there are also specialised Croatian companies involved in plant breeding and reproduction. Agricultural machinery and sorting and packaging equipment is also often imported.

The farms deliver harvested produce either to local warehouses/pack houses, to wholesalers, to the processing industry, to local green markets and in some cases directly to retailers. The choice for the type of a buyer depends on the size of the farm, the regional supply chain facilities available, the product and whether or not it is destined for processing, and of course on the customer demand and choices regarding customers and target markets involved with it. In Neretva valley, there are up to 10 packers/wholesales of satsumas, of which AgroFructus is the largest one.

Most wholesalers are small companies too. A few are larger companies targeting both domestic and foreign retail customers. The largest ones (with respect to the selected products in this study) are AgroFructus, Tutti Frutti and Jasenska. The wholesalers collect produce from local growers. They inspect the quality of the product, wash and package according to customers wishes. Some of the wholesalers have specific facilities for the collection of smaller batches from small producers and redistribute to e.g. local restaurants and other smaller customers.

Croatia is a net-importer of all selected vegetables. Mandarins, apples and sour cherries are exported, but the fresh F\&V supply chain is primarily a domestic affair. Nevertheless, international trade is increasing. Both import competition is increasing and export opportunities are emerging with the integration of Croatia in the single European market and further globalisation of the Croatian economy. Some of the larger processors have developed strong brands and export to a multitude of countries. 
Agrokor

Agrokor and its subsidiaries are a major player in the Croatian fruit and vegetables supply chain.

Agrokor was originally established as a flowers trading company, and grew into the largest agro-food company of Croatia. The joint stock company is active in Croatia, Serbia, Slovenia and Bosnia and Herzegovina, in agricultural production, wholesale, processing and retail of food products, and in tourism. The combined turnover of Agrokor d.d. was $€ 4.85 \mathrm{bn}$ in 2016. Agrokor and its subsidiaries are the largest employer in the Balkans with 60,000 employees, representing $16 \%$ of Croatian GDP.

Since the beginning of 2017, Agrokor has faced severe financial difficulties. In March talks between the Croatian Government, the biggest creditor Sberbank and other financial institutions including EBRD, and suppliers were held to resolve the situation. 'A stand-still arrangement was made with the banks, and the banks will give additional loans for settling the debts towards suppliers. New management will be installed and restructuring of the whole concern is planned' (Source: Orbis, Bureau van Dijk; situation March 2017).

The financial troubles of Agrokor have gradually increased. Since 2006, the corporation's solvency rate deteriorated from $32.5 \%$ to as low as $14.5 \%$ in 2016 . The company was still making a small profit, although the later revised reports showed losses which led to Agrokor management being accused of tampering with the company's financial statements. Creditors and loans have increased to such a point that severe measures were ultimately necessary.

Despite the problems that Agrokor faces, it still takes up a prominent place in Croatian food production and trade. The largest retailer Konzum is part of the group, as well as a number of agricultural production and trade companies. Agrokor has invested heavily in Croatian fruit and vegetables production, processing and distribution. It established large distribution centres, invests in irrigation and orchards, and has provided technical assistance to a lot of farmers over the years. By focusing on Croatian produce, it has been an important anchor for Croatian farmers.

The negative financial situation brings negative consequences for suppliers including fruit and vegetables growers. Payment terms have increased. Late payments means less means for investing in the following production season. Grower with no financial back-up - including the smaller ones - that used to sell exclusively to Agrokor's firms have been affected by late payments the most. There is no information about the exact impact related to Agrokor's difficulties on the number of farms or production volumes. However, the interviewed growers for this study indicated to be encouraged to find a way to stay in business by spreading the risks and seek other buyers.

Agrokor has started a major financial and organisational restructuring of its business. The first in terms of business performance are positive (situation December 2017). As yet, no ultimate future prospect for Agrokor has been defined, as the negotiations with creditors and suppliers about the financial settlement plans are still ongoing. This creates an insecure position for all involved parties in the agricultural sector.

See Agrokor's official websites for the current status at http://www.agrokor.hr/en/ and http://nagodba.agrokor.hr/en/

\subsection{Growers: farm size and income}

\subsubsection{Many small and unspecialised farms}

To first sketch the role of fruit and vegetables production in Croatian agriculture, Figure 3.2 gives an overview of the number of farms that are specialised in certain types of crops, animal production or combinations of various crops and/or animals.

In 2013, there were about 157 thousand farms in Croatia. About 21 thousand farms were mainly producing cereals, oilseed and protein crops, while 12.5 thousand farms were categorised as 'general field cropping'. This diverse group includes potatoes and other root crops, brassicas, and open field vegetables and melons, and also tobacco. Only about 2,300 growers were categorised as specialist horticultural firms of which 1,100 were mainly producing indoor (Eurostat). Some 7,000 holdings were mainly producing fruit, including citrus fruit, and 7,650 farms were of the farm type 'various permanent crops combined'. The vast majority of farms in Croatia produces various crops or combines crops and livestock. About 29 thousand farms are not specialised in either crops or livestock but combine both, while 19.5 thousand farms are categorised as 'mixed cropping'. General field cropping, specialist horticulture and fruit together represent about $19 \%$ of the total number of farms in Croatia in 2013. 


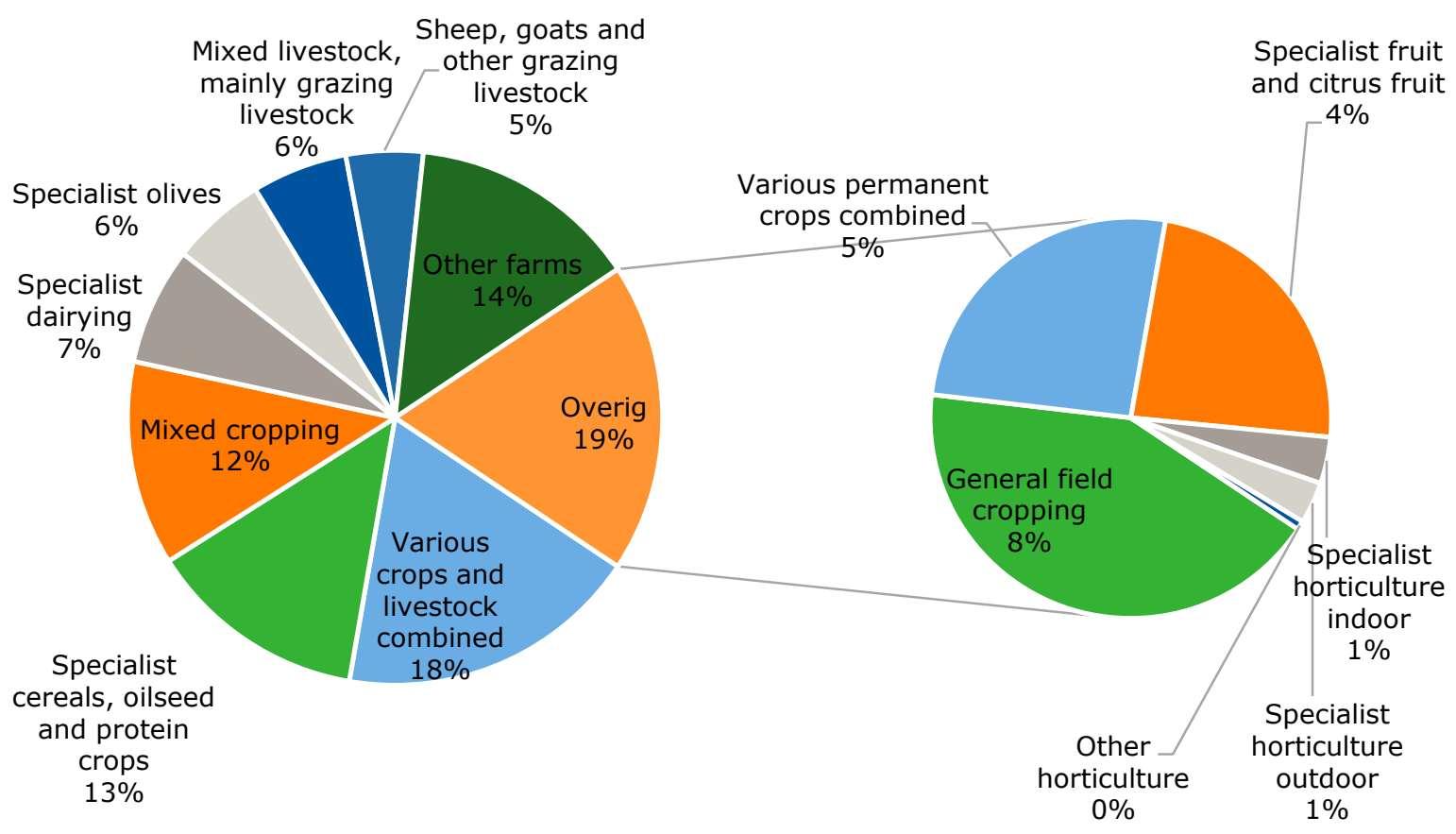

Figure 3.2 Number of farms, top-7 main farm types plus selected specialised horticultural farm types, 2013

Source: Eurostat, calculations Wageningen Economic Research.

The vast majority of farms is located in the Kontinentalna region

Of all farms, only about 37 thousand were situated in the Jadranska region. Although all farm types are represented in both regions, most arable farms with cereals and oilcrops, as well as mixed cropping, livestock and crops combinations, and dairy farms can be found in the Kontinentalna region. The Jadranska region is dominated by olives, vineyards, fruit and other permanent crops, as well as sheep and goats.

Fruit and vegetables production in Croatia is mostly characterised by small-scale farms According to Eurostat and the Croatian Bureau of Statistics (Farm Structure Survey) there were 14,130 companies in 2013 with production of fresh vegetables, melons and strawberries. These farms are not necessarily specialised in the production of vegetables, melons or strawberries. In Croatia most farms combine the production of various crops and livestock. Almost 6 thousand of these firms were less than 2 ha in size. For citrus fruit plantations there were 7,630 firms in 2013, of which 6,250 were reported to have less than 2 ha. Fruit and berry producers were the most numerous with a total of 105,940 companies in 2013 , which means that over two thirds of all farms in Croatia were also engaged in the production of fruit or berries. It also has the highest share of companies with larger production areas (see Figure 3.3). 


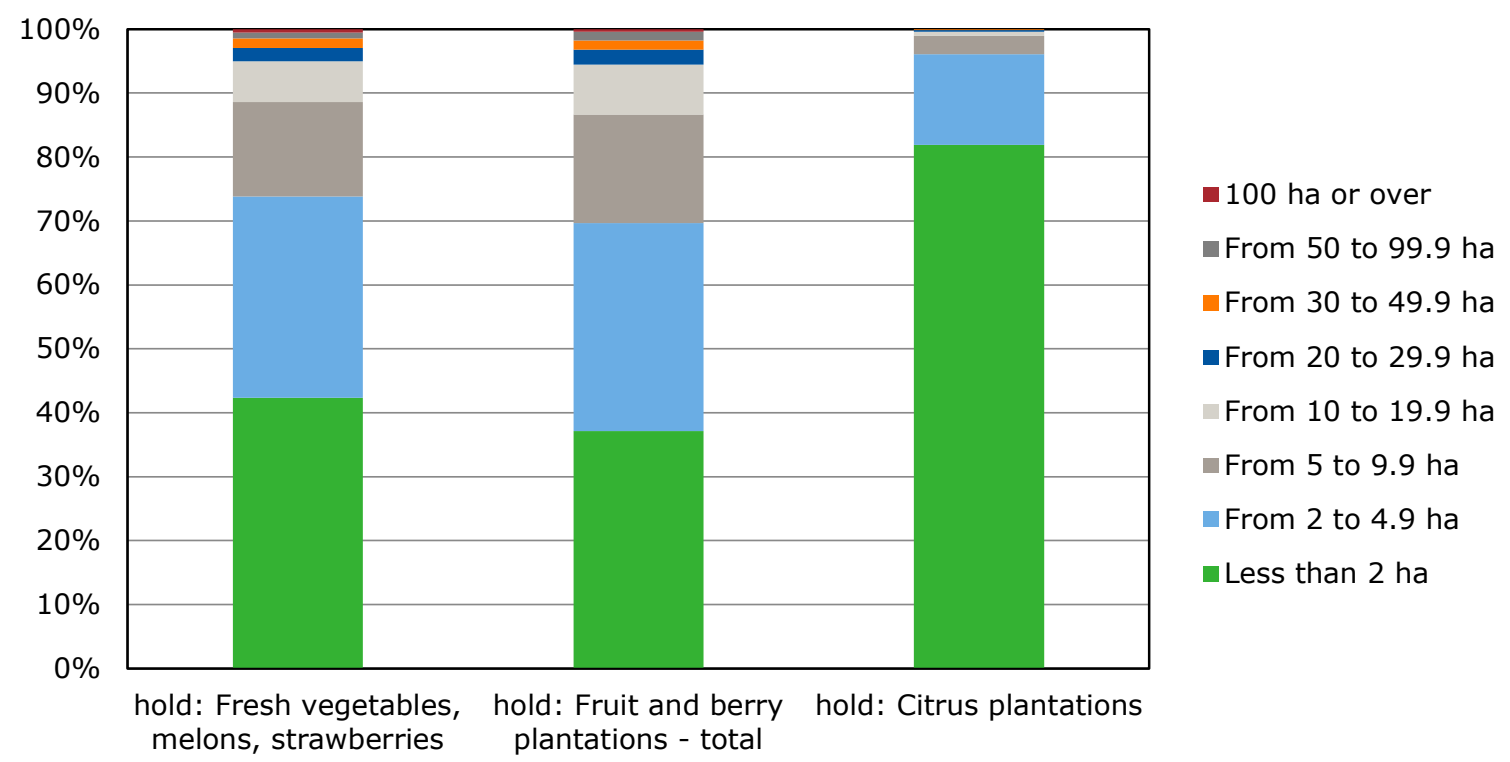

Figure 3.3 Division of number of holdings per size category with production of fresh vegetables, melons, strawberries, fruit and berry plantations; and citrus plantations in Croatia, in 2013 Source: Eurostat, ef_oluaareg.

\section{The average size of the farms in Croatia are small also compared to many other EU countries}

Figure 3.4 to Figure 3.7 show the division of farms in farm types 'general field cropping' ${ }^{5}$ and 'specialist horticulture indoor', 'specialist horticulture outdoor', and 'fruit and citrus fruit' by economic size. Specialist horticulture indoor and outdoor may cover partly the same type of products, depending on whether they are grown in the open field or under greenhouses or other accessible cover. The countries are sorted on the basis of the weighted share of farms per size class to obtain an estimate of average size. The figures show that the average size of the farms in Croatia are small also compared to many other EU countries. Especially in outdoor horticulture. For fruit we notice that farms are smaller in Croatia than in competing countries like Greece, Italy, Spain and Poland. Data regarding the economic size of specifically citrus fruit producers is not available. It is however a known fact that mandarin production in the Neretva valley is characterised by many small growers.

\footnotetext{
5 General field cropping includes root crops like potatoes and sugar beet, combinations of cereals, oilseeds, root crops and other crops, and also open field vegetables including brassicas, melons and strawberries grown in the open field. Some 1,250 companies in Croatia under general field cropping are producers of tobacco.
} 


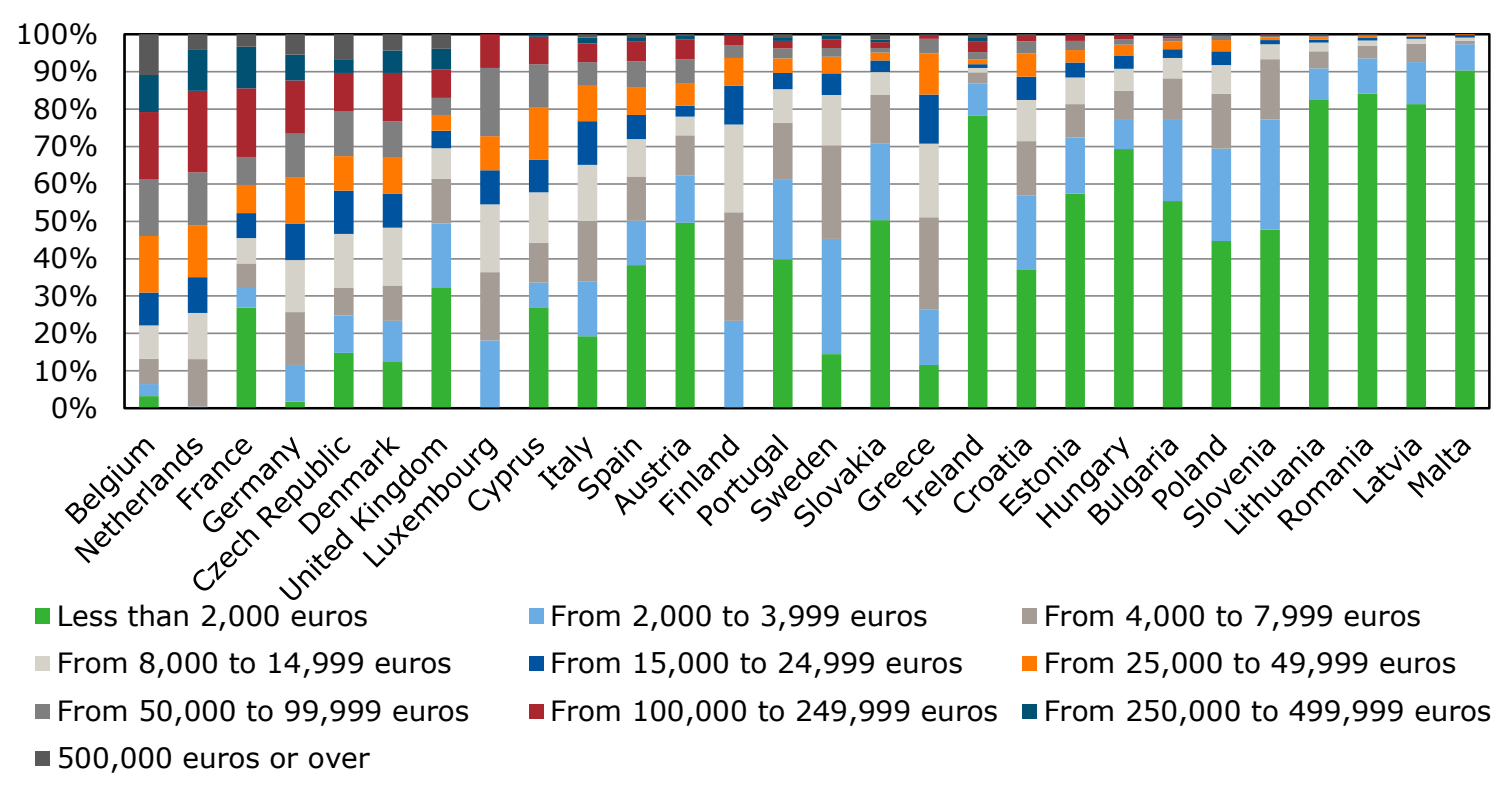

Figure 3.4 Farm holdings specialised in general field cropping by economic size (SO), EU-28, 2013 (sorted by estimated average based on midpoints of economic size classes)

Source: Eurostat ef_kvftecs, calculations Wageningen Economic Research.

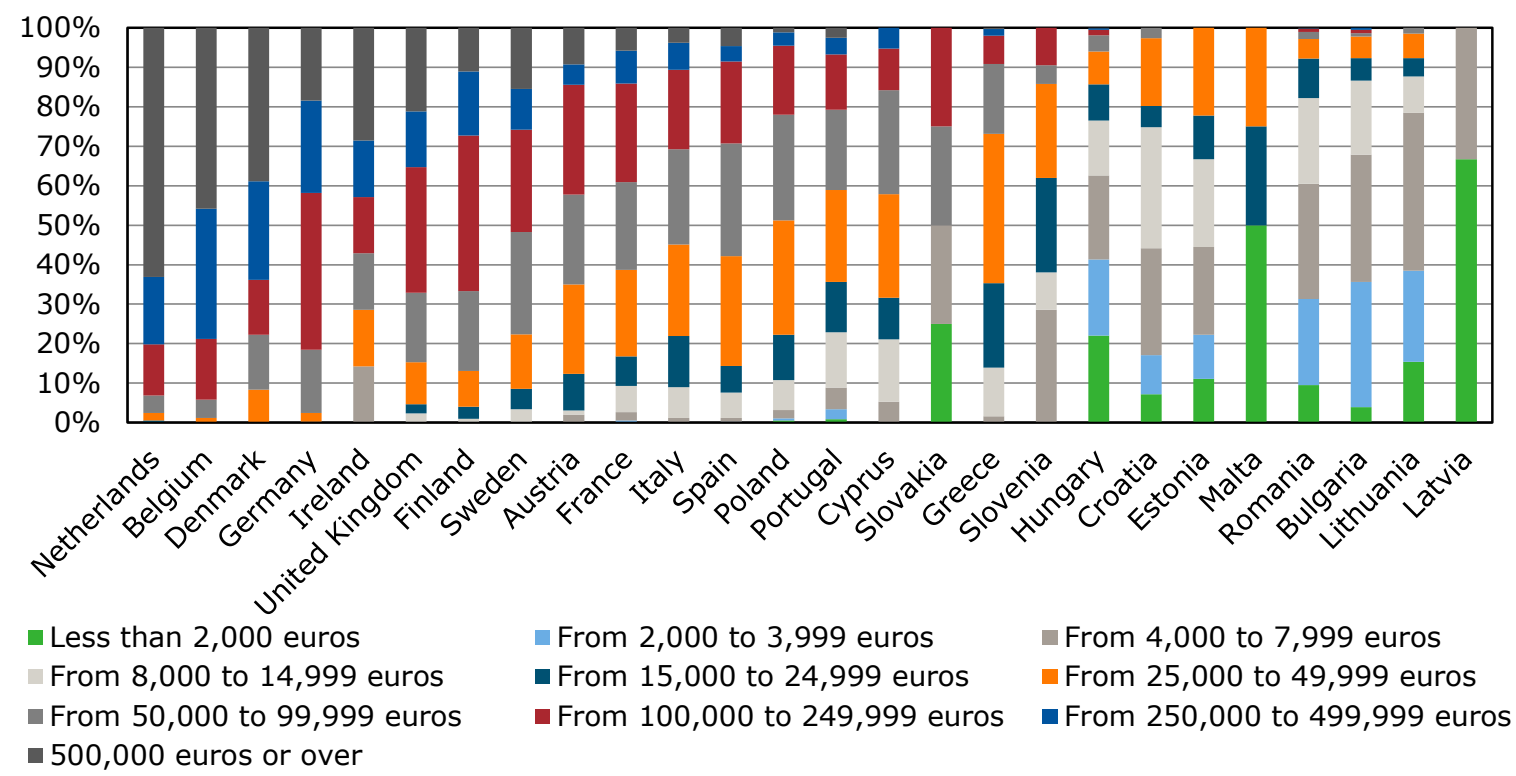

Figure 3.5 Farm holdings specialised in indoor horticulture by economic size (SO), EU-28, 2013 Source: Eurostat ef_kvftecs, calculations Wageningen Economic Research. 


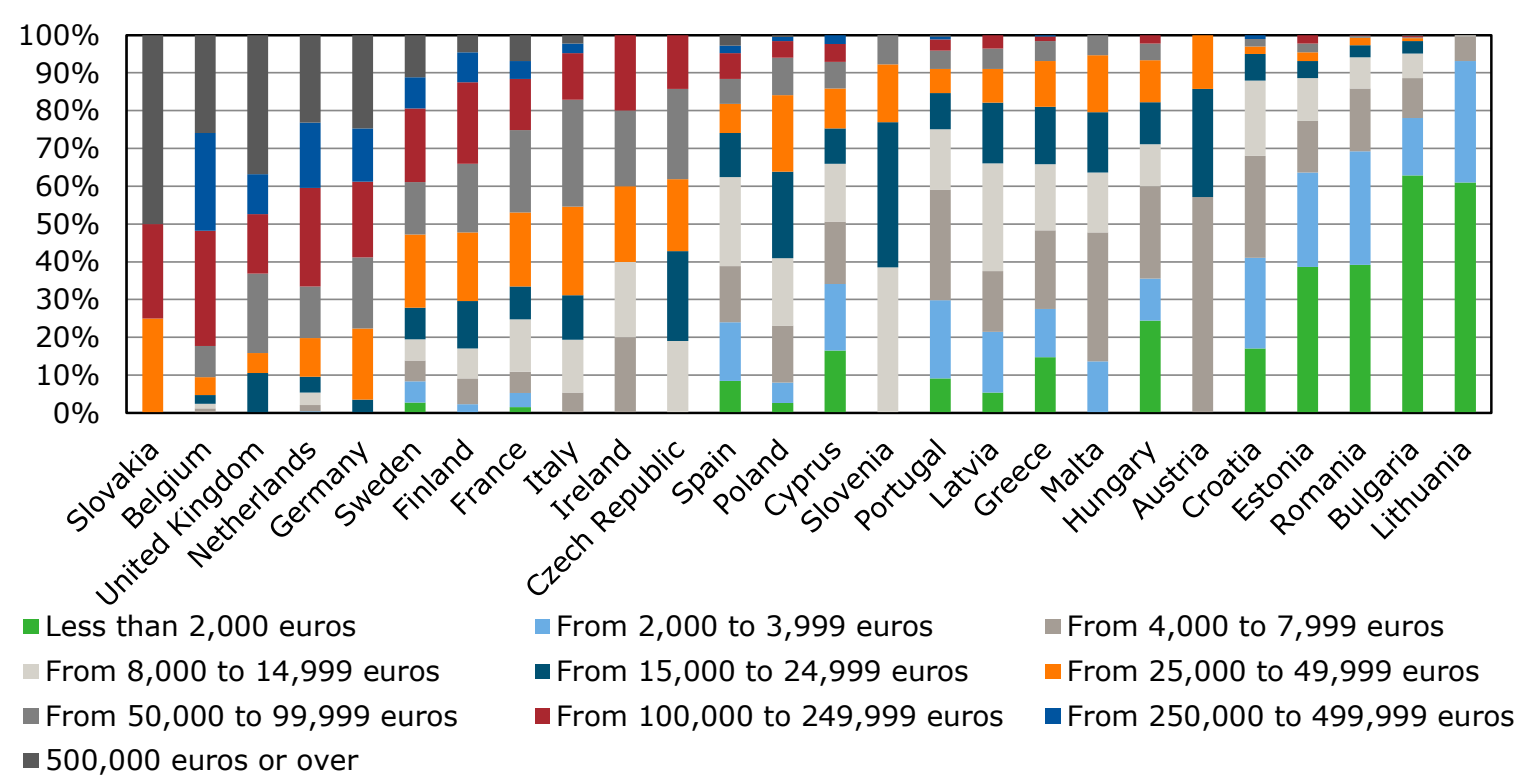

Figure 3.6 Farm holdings specialised in outdoor horticulture by economic size (SO), EU-28, 2013 Source: Eurostat ef_kvftecs, calculations Wageningen Economic Research.

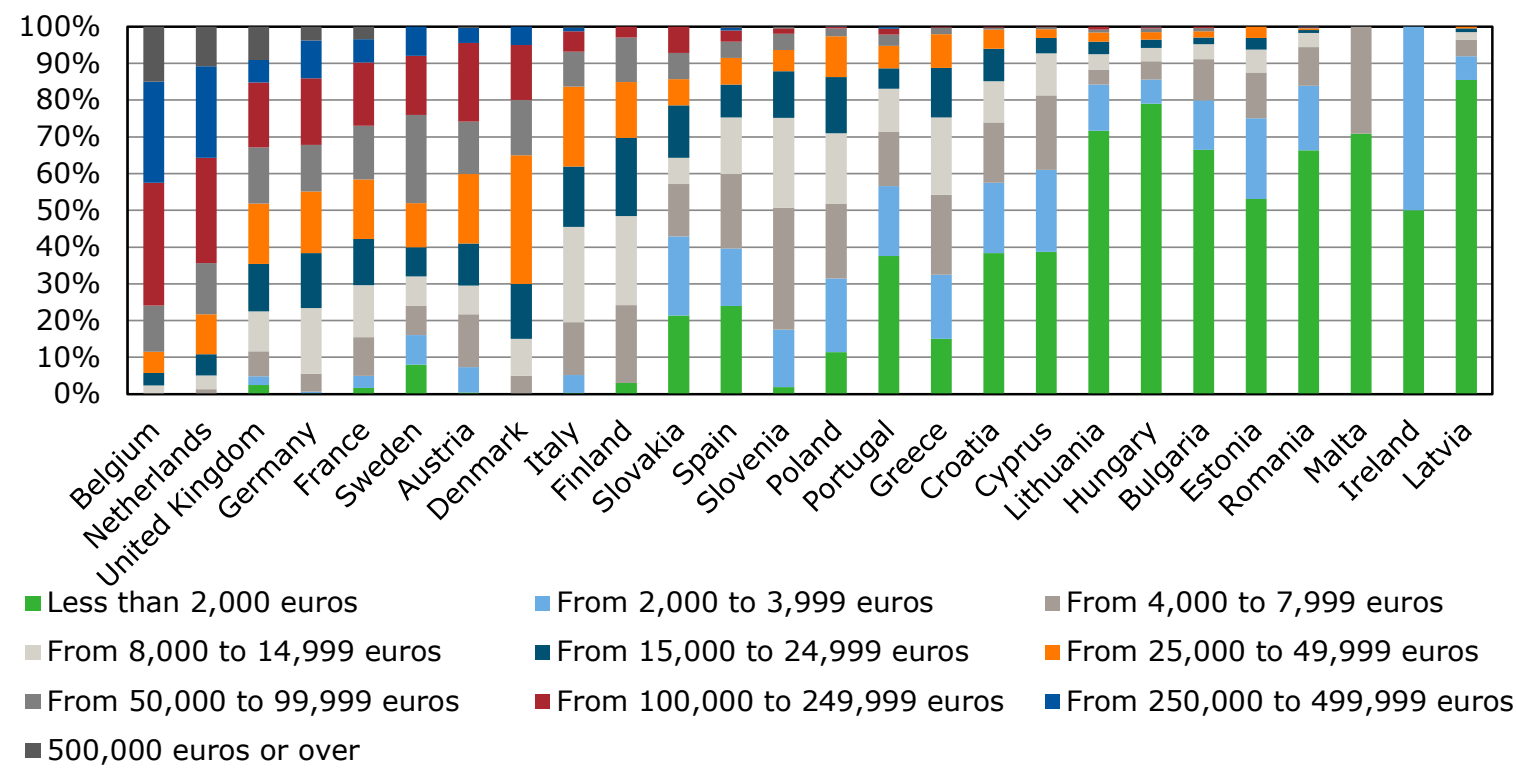

Figure 3.7 Farm holdings specialised in fruit and citrus fruit by economic size (SO), EU-28, 2013 Source: Eurostat ef_kvftecs, calculations Wageningen Economic Research.

When we look at the division of citrus fruit producing farms by area, it becomes clear that the Croatian producers are smaller in size than the other citrus producing countries. 


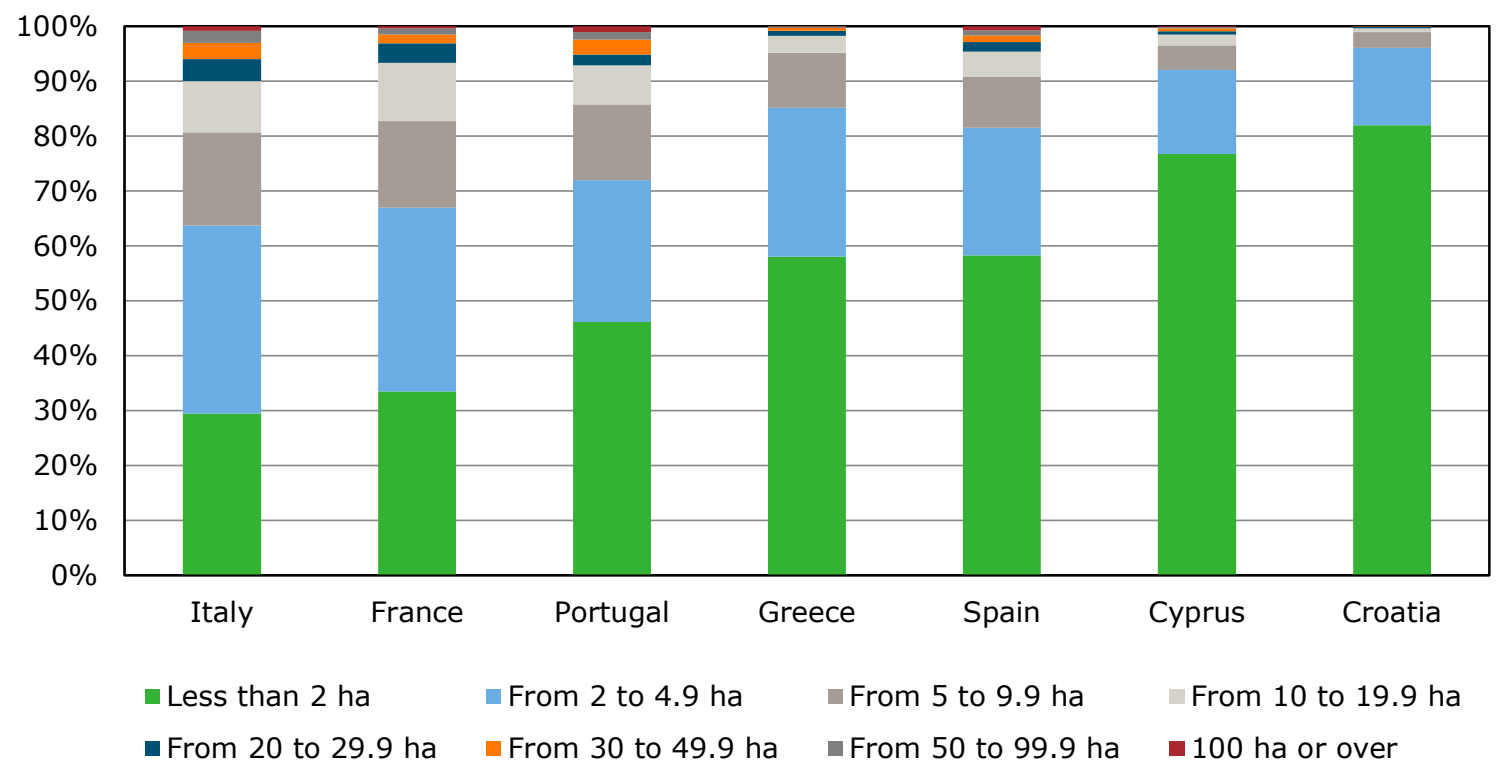

Figure 3.8 Share of citrus plantations by size of farm, 2013

Source: Eurostat ef_oluaareg, calculations Wageningen Economic Research.

The number of farms is falling and this is especially true for smaller farms. The number of specialised horticultural farms (including general field cropping and ornamental plants and flowers) with less than 2 ha fell by $22 \%$ between 2010 and 2013, while the number of farms larger than 10 ha was more or less stable. The decrease in the numbers of farms was most prominent in general field cropping and other horticulture. For fruit and 'various permanent crops combined' the decrease was more modest, while an increase in the number of specialised horticultural farms was observed.

Most notably the number of indoor horticultural firms increased from 360 in 2010 to 1,100 in 2013. Although the total area is still limited, the area of greenhouses is growing. In 2013 there were about 440 hectares of vegetables under greenhouses (Eurostat). Since then, several firms have invested in ultra-modern greenhouses. Some of these are co-financed by from the European Agricultural Fund for Rural Development. Still the numbers show that the average greenhouse was only 0.4 ha.

Between 2010 and 2013 the number of farms in general field cropping has fallen substantially from 20 to 12.5 thousand while the area of production increased from 157 to 422 thousand hectares (Source: Eurostat Land use: number of farms and areas of different crops by type of farming (2-digit) [ef_oluft]). This is in part caused by the land reform measures. It has led to an increase in the average size of horticultural firms. Especially in general field cropping where the average farm grew substantially. More recent data are not available. The increase in farm size is expected to continue as land reform measures are still being implemented.

Some examples show how the small average size of farms is hampering the performance of the fruit and vegetables chains as a whole. Maraska d.d., a leading producer of cherry based drinks and other fruit products, has decided to produce almost all cherries themselves, on a total of 200 ha. In the past cherries were also bought from local growers, but their small relative size led to major inefficiencies. Interviews with supermarkets and other actors have revealed that supermarkets have a large preference in dealing with larger suppliers or cooperatives, or intermediates that bundle the volumes from the smaller farmers. Dealing with a lot of individual small suppliers causes substantial transaction costs.

If good quality produce is available from Croatia, most supermarkets indicate to have a preference for local produce. A preference for local produce is also revealed by the appearance of special labels on packaged produce indicating the Croatian origin. However, supermarkets are large buyers that demand large quantities of uniform quality produce every day. And although generally there is good quality produce available from Croatia, supply does vary throughout the year, and the amount of sufficient quality produce is often not enough to supply supermarkets consistently throughout the 
season, let alone throughout the year. All supermarkets import fresh produce on a regular basis. Supermarkets compete with one another and in the end, prices are often a very important buying criterion. Freshness, Good Agricultural Practices, absence of crop protection residues, consistent availability, taste and look are other important buying criteria. Without fulfilling all of these criteria, in the supermarkets channel, competition with imported produce on the basis of a preference for local produce alone is not feasible.

\subsubsection{Croatian horticulture income lagging behind}

Data on profitability of specific fruit and vegetables products are not available. However, we do have data from FADN on family farm income per farm working unit for specialist horticulture and for specialist fruit orchards (excluding wine). The data clearly show how Croatian horticulture is lagging behind the benchmark countries.

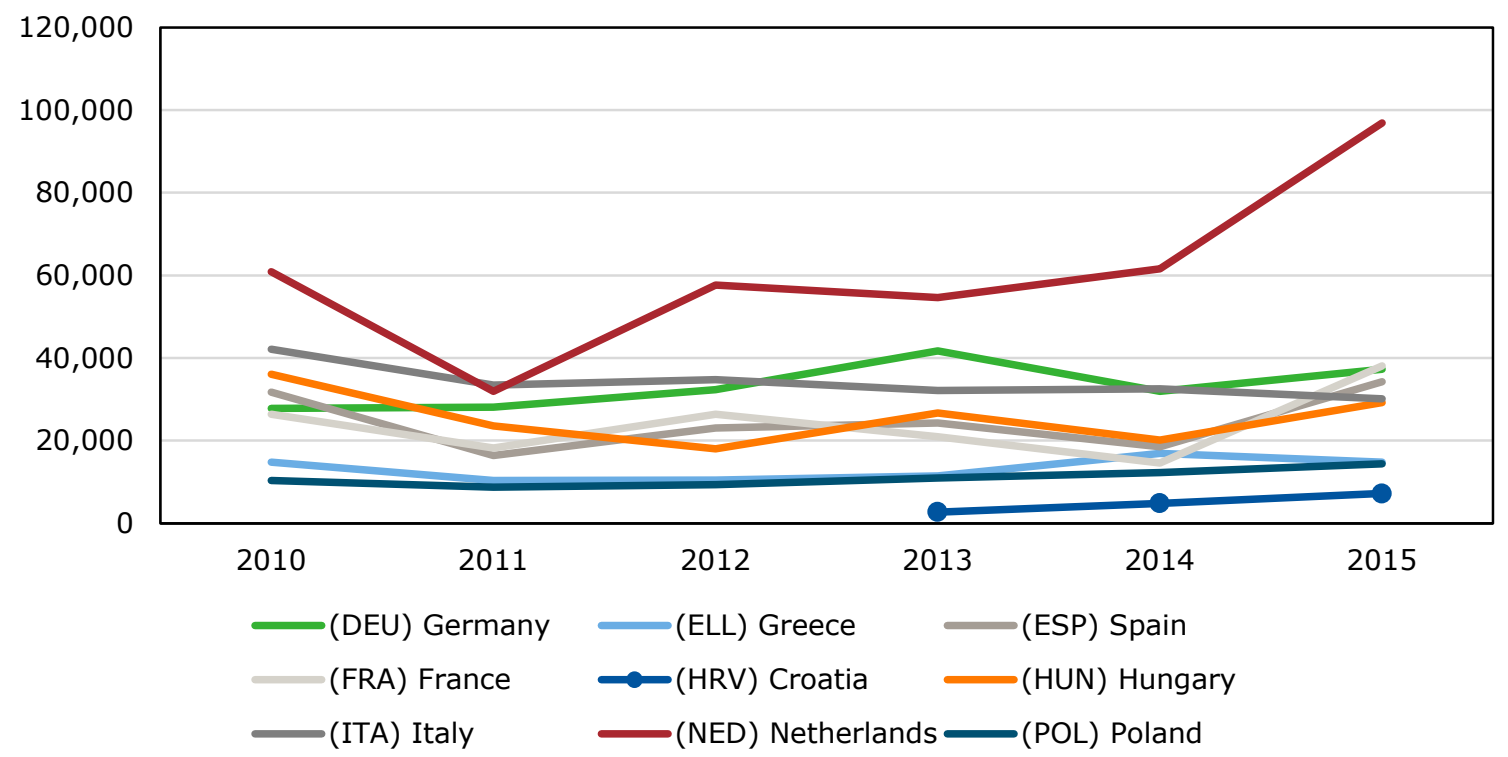

Figure 3.9 Family farm income per farm working unit, for specialist horticulture, 2010-2015, in $€$ Source: EU FADN Database.

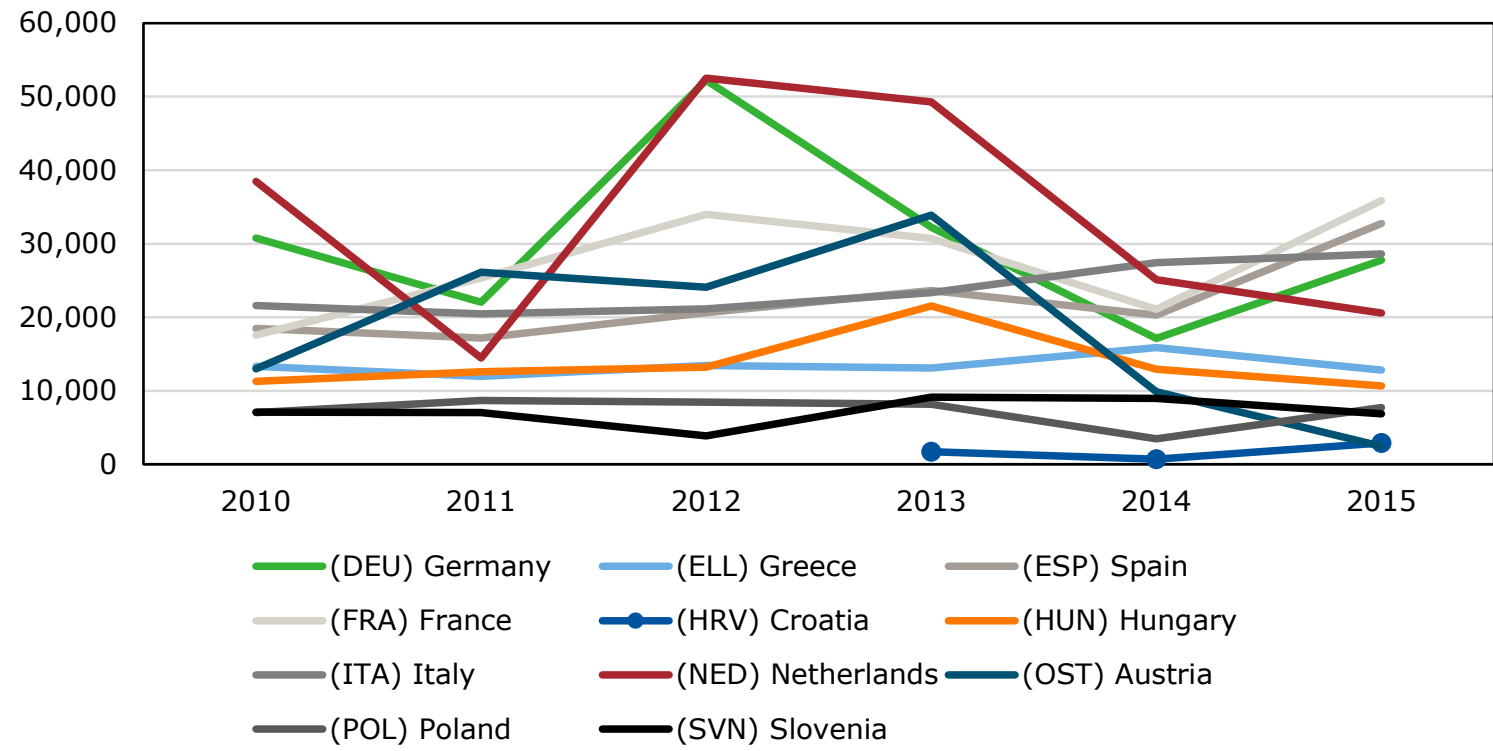

Figure 3.10 Family farm income per farm working unit, for specialist fruit orchards, 2010-2015, in € Source: EU FADN Database. 


\subsection{Fruit and vegetables wholesale: several big players, low profitability}

According to Eurostat there were 194 companies specialised in wholesale of fruit and vegetables in 2015. Together these companies reported $€ 244 \mathrm{~m}$ of turnover. Agrokor and its subsidiaries are the largest wholesaler and retailer of food products including fruit and vegetables in Croatia.

On the whole, a structural analysis of the fruit and vegetables wholesale industry in Croatia shows that the $10 \%$ largest firms have about $80 \%$ of total turnover in wholesale trade of fruit and vegetables. ${ }^{6}$ AgroFructus, Tutti Frutti and Jasenska are the leading companies that focus on distribution of Croatian produce. A number of other large companies focus mainly on imports of e.g. bananas, like Dodir Prirode. Only 8 Croatian companies in the fruit and vegetables wholesale business had a turnover of more than $€ 5 \mathrm{~m}$ in 2016.

The fruit and vegetables wholesale branch in Croatia was not very profitable in the past 5 years (2012-2016), but nevertheless displays mostly positive results. The average profit margin fluctuated between -0.4 and $1.6 \%$ (based on 88 to 127 observations of fruit and vegetables wholesale companies in Croatia in Orbis, Bureau van Dijk), which is not too bad for a wholesale industry. Nevertheless, in the same five-years period, wholesalers in a range of other competing countries were slightly more profitable, and also seem to have been able to increase their profit margins whereas Croatian wholesalers have not (see the figure below). Average profit margins have been calculated on the basis of the sums of net profits and turnover of those companies for which both indicators are present in the database in the respective year. Note that large companies hence have a larger influence on the calculated average. Solvency, current ratio and gearing were generally healthy.

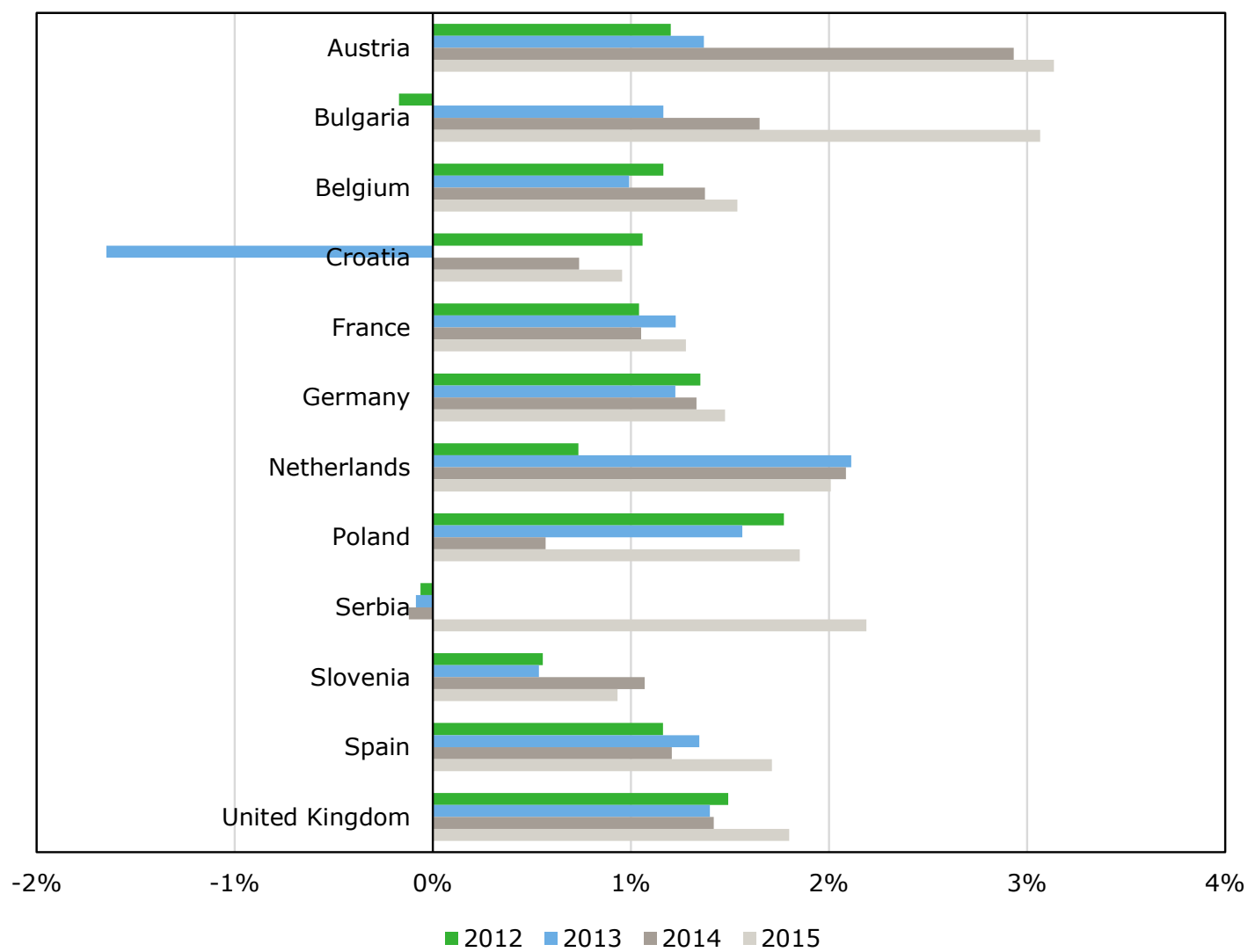

Figure 3.11 Estimates of average profit margins of fruit and vegetables wholesale companies in selected countries

Source: Bureau van Dijk Orbis Database, calculations Wageningen Economic Research.

${ }^{6}$ Tenth decile of firms with core activity code Wholesale of fruit and vegetables, ranked by turnover in 2016. Source: Orbis database by Bureau van Dijk. 
In 2016, on average, about $88 \%$ of all costs of Croatian fruit and vegetables wholesalers are related to the costs of purchasing products, $5 \%$ was personnel costs, $3 \%$ of the costs was depreciation and $3 \%$ consisted other expenses (estimates on the basis Orbis database of Bureau van Dijk). If we compare that to e.g. the Netherlands, the relative costs of depreciation are much higher in Croatia. Although the figures differ greatly between companies, a simple analysis of averages shows that in Croatia 3\% of the total costs consisted of depreciation while in the Netherlands this was less than $1 \%$ on average. Capital is being used less efficiently in Croatia. On the other hand the relative costs of personnel is lower in Croatia than in the Netherlands. Because tangible fixed assets did not increase much on average in the past 5 years, it seems that there is underutilisation of assets.

\subsection{Processing: Croatian firms process locally grown products}

Although in terms of volume more processed fruits and vegetables are imported than produced locally, still, Croatia has a strong food processing sector, which produced 851,000 tonnes of fruit juices, 11,000 tonnes of canned vegetables, and 13,000 tonnes of vegetables preserved in vinegar in 2009. In 2009 Croatia exported fresh fruit $(€ 15 \mathrm{~m})$, fresh vegetables $(€ 2.9 \mathrm{~m})$, and processed fruits and vegetables $(€ 20 \mathrm{~m})$, excluding fruit juices.

Within the EU, Croatian fruit and vegetable processing is rather small, less than $1 \%$ of the EU28. The leading Member States were Italy (18.9\%) and Spain $(14.5 \%)$, which alone produced over one third of the total value. They were followed by Germany (11.8\%), France (11.35\%) and the United Kingdom $(11.0 \%)$ (Eurostat). ${ }^{7}$

Domestic food processing companies Ledo d.d.(Agrokor group) and Podravka d.d. are leading in Croatia. Ledo leads on processed frozen fruits and vegetables, Podravka has a strong position on shelf stable fruits and vegetables. Among its products are canned tomato products mainly for export purposes. Other actors in fruit and vegetables are Maraska d.d. and smaller companies are specialists in Sauerkraut for local retail and export markets. Companies like Podravka, Ledo and Maraska have developed strong internationally recognised brands. Croatia largest vegetable producer PIK Vinkovci (Agrokor group) is also a specialist in frozen fruits and vegetables (6.8 thousand tonnes per year). Maraska d.d. is a producer of products based on cherry Maraska and a post-harvest service provider. Products are cherry-based alcoholics for worldwide export and non-alcoholics like juices.

Fruit and vegetables processing companies prefer to collect their fruit and vegetables input from surrounding regions as transporting input products over a too long distance is costly and leads to deterioration of quality. Processing plants are located in the area where fruit and vegetables are grown. Some processing companies have secured their raw materials supply by exploiting contract farming practices. Contract farming can lead to an unfavourable position for growers in e.g. facing the risks of market failure and production problems, manipulation of quota and weak market position. But in a trustful relation between growers and processing companies contract farming has advantages for growers in reducing price risks, learning and implementing new technologies, getting inputs and production support from the processing company and favourable investment credit conditions. The interviewees indicated that the growth of some processing companies has given a boost to individual farming in regions where processing facilities are located.

Contract farming can open up new markets which would otherwise be unavailable to small growers (FAO, Partnerships for growth). However, in the long term, buyers will seek for more efficient methods of raw material supply. The availability of supply of a certain volume and quality is one of the major concerns of processing companies. For this reason, some processing companies apply vertical chain integration, having their own production facilities.

\footnotetext{
7 http://ec.europa.eu/eurostat/statistics-explained/index.php/The_fruit_and_vegetable_sector_in_the_EU__a_statistical_overview\#Processing
} 


\subsection{Retail: a changing landscape}

The food retail sector in Croatia has changed considerably after its independence from Yugoslavia in 1991. Until 1991, most food retail shops were socially-owned enterprises (according a socialist selfmanagement model) with small and medium-sized shops. Between 1991 and 2000 privatised retail chains and numerous independent shops dominated the retail market. A quick development of the supermarket channel emerged in the second half of the 90's. But fruits and vegetables were still mainly sold at smaller shops and green markets.

After 2001, foreign retail chains entered the market. Introduction of business models of superior efficiency and higher quality standards, strengthened consumers' demand for high quality fruit and vegetables. It forced the domestic retailers to quickly adjust to these new developments to stay in business. Supermarkets increased their share in the total grocery retail from 25\% in 2000 to $51 \%$ in 2002, and increasingly became an important sales channel for fruit and vegetables (Götz et al., 2009). The retail channel is currently an important sales channel for the domestic fruit and vegetable products. The total turnover of the whole food retail market has gradually increased due to favourable economic conditions (see Figure 3.12).

The first two decades of the 21 th century are characterised by significant dynamics in the retail channel due to severe competition between the existing supermarket formula's trying to strengthen their positions and new retailers entering the Croatian market, like Lidl (Schwartz Group) and Spar.

Average profit margins in the retail have been between $1 \%$ and $3 \%$ in the past 10 years, but differences between retailers were large (based on Orbis, Bureau van Dijk). Foreign supermarkets like Lidl were entering the market with a market penetration strategy, investing heavily and making a loss during the early years of their market presence. This has had a negative effect on some of the existing retailers' profits margins, most notably on Konzum, who's average profits have gradually decreased in recent years. Tommy and Plodine, the other major Croatian retailers, have managed to keep profits more or less at their former levels.

Currently, discounter Lidl is the second largest retailer in Croatia and is expected to continue increasing its market share. Spar obtained over 8\% retail market share in 2017 (see Table 3.1) (IGD, 2017) and became the third retailer in Croatia. Spar was sparsely present in Croatia until 2016, when the company acquired 62 Billa supermarkets (see Figure 3.12 and Figure 3.13). Domestic market leader Konzum saw its market share decline from 40\% in 2007 to $20 \%$ in 2017 (IGD, 2017) (see Table 3.1) and this decline is expected to continue in 2018. The loss of Konzum's market share in most recent years has been partly caused by suffering from a negative image spill-over from Agrokor due to its financial crisis (see Agrokor's introduction in Section 3.2). 


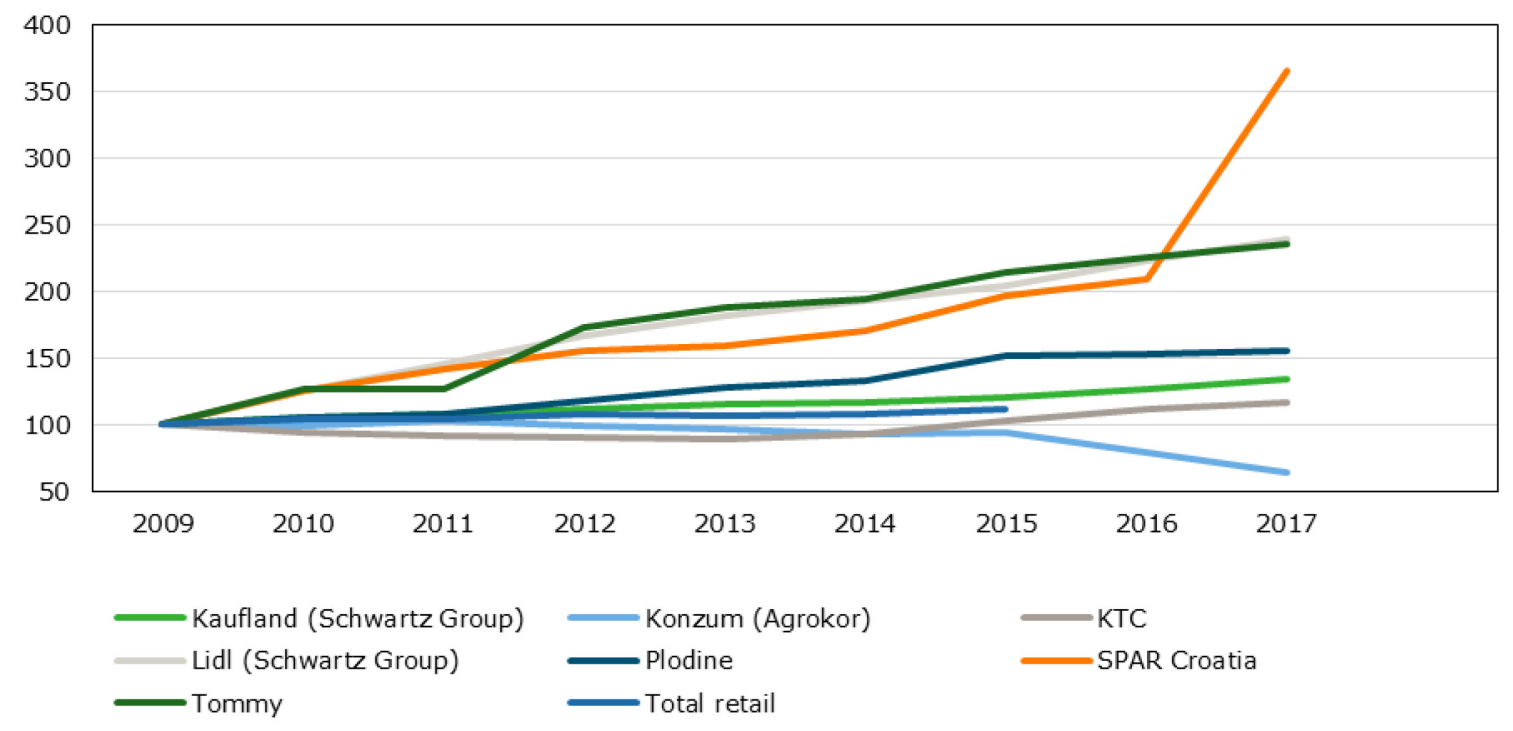

Figure 3.12 Development in sales of the total retail and the largest retailers active in Croatia in 2017 $(2009=100)$

Source: IGD Datacentre 2017; Eurostat sbs_na_dt_r2. Calculations Wageningen Economic Research. Total retail sales data not available after 2015.

Table 3.1 Market shares of major supermarkets in Croatia, 2017, in \%

\begin{tabular}{lr} 
Retailer & 2017 \\
Agrokor (Konzum)* & 20.3 \\
\hline Schwarz Group (Lidl and Kaufland) & 14.3 \\
\hline SPAR International & 8.3 \\
\hline Plodine & 6.6 \\
\hline Tommy & 3.9 \\
\hline KTC & 2.4
\end{tabular}

Source: IGD Retail Analysis.

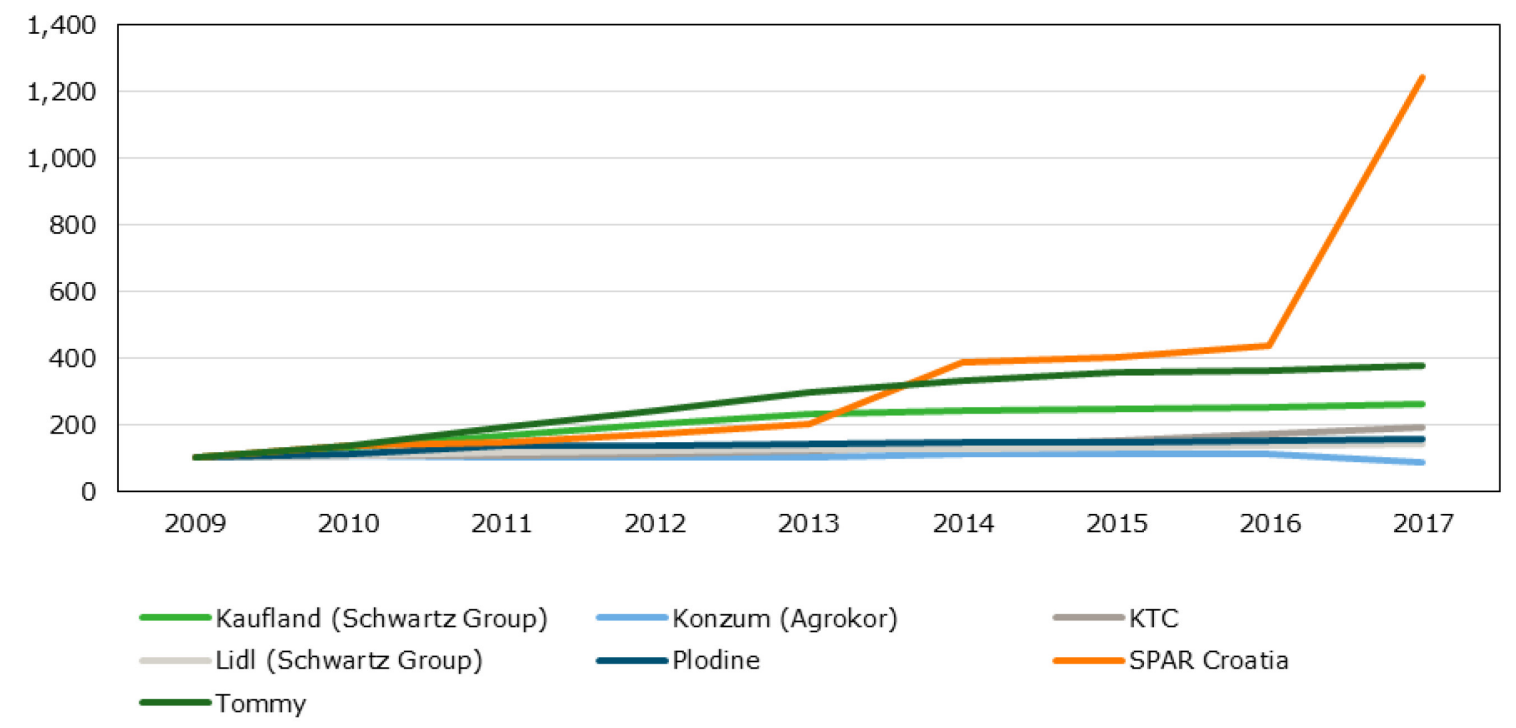

Figure 3.13 Number of outlets of the largest retailers active in Croatia in $2017(2009=100)$ Source: IGD Datacentre 2017. Calculations Wageningen Economic Research. 
Konzum has been a traditionally important sales channel for domestic fruit and vegetables being able to organise its procurement within Agrokor. New foreign supermarkets have organised both foreign and domestic fruit and vegetables procurement, which leads to opportunities for Croatian suppliers in differentiating their sales channels. At the same time, with the opening of the EU market after the Croatian accession, the competition on the supply site increased as well. New foreign retailers have more focus on getting a good deal, instead of maintaining domestic supply structures.

Supermarkets, like Austrian-based Spar and the domestic market share leader Konzum have traditionally put their focus on product quality and differentiation, and service. This strategy is an opportunity for less competitive domestic products. A separate retail marketing strategy for domestically-sourced products fits into the product differentiation approach and has been quite successfully applied in some cases. In some cases, supermarket are promoting Croatian produce, even when purchasing prices are higher than prices of imported produce. ${ }^{8}$ Still, when domestic supply is more costly, supermarkets have to consider what is an acceptable surcharge for a domestic product for consumers. And whether the surcharge is low enough to fit in a supermarket's business model.

The emerge of discounter Lidl that follows a cost and price leadership strategy shows that low consumer prices turned out to be a successful retail strategy in Croatia. When protecting their market share, full-service supermarkets are expected to react on competitors' lower consumer prices, reconsidering their own price schemes and the costs of the supply. Eventually such developments will put more competitive pressure on suppliers, which is especially a threat to smaller Croatian producers who cannot produce and distribute at lowest costs.

\subsection{Cooperation between chain actors: horizontal and vertical}

\section{Legacy of socialist era}

A consequence of the war in the 1990s has been a complete change of the system, regarding both the governmental and the agricultural. Agricultural conglomerates as an organisational type decreased in popularity and privatisation took place. Although agricultural conglomerates were not perceived as an ideal organisational structure, the changes in their structure were not accompanied with a clear view of a desired agricultural farm structure in the future. After privatisation, often irrational management led to difficult financial situations. Privatised conglomerates were sold at low prices, which at the end caused conglomerates to be divided into smaller companies. These smaller companies, in their turn, did not always succeed to survive on the market. With disappearing of conglomerates, individual private farmers were obliged to develop their own product marketing next to farming activities.

\section{Low number of cooperatives}

In 2016 there were 1,302 cooperatives in Croatia, of which $41 \%$ was active in agriculture. ${ }^{9}$ In 2012 , 276 cooperatives were active in crop production, or $54 \%$ of the total number of agricultural cooperatives in that year (Nedanov and Žutinić, 2015). The agri-cooperatives including fishery and food manufacturing had a combined turnover of $€ 166 \mathrm{~m}$ in 2013 . Of all EU MS, Croatian cooperatives have the lowest total turnover, with the exception of Cyprus. ${ }^{10}$ With a total agricultural output exceeding $€ 2 \mathrm{bn}$ in Croatia and food manufacturing exceeding $€ 4.5 \mathrm{bn}$ in turnover, we estimate that the market share of the agricultural cooperatives does not exceed $2.5 \%$. In comparison to the other EU Member States the market share of cooperatives is very low. Only in Romania and Bulgaria lower market shares of cooperatives were reported (2010). ${ }^{11}$ During the interviews the reluctance toward farmer cooperatives was explained by farmers by the lack of trust and by issues with distribution of means within the cooperative. These attitudes of farmers are confirmed by the study of Lončarić et al.

\footnotetext{
8 See for example https://www.total-croatia-news.com/made-in-croatia/23965-konzum-to-offer-food-from-local-smallfamily-farms, https://www.total-croatia-news.com/item/14748-domestic-producers-find-their-place-on-lidl-shelves 9 http://www.cepor.hr/wp-content/uploads/2015/04/Cepor-izvjesce-2016-ENG-web.pdf

${ }^{10}$ http://epkk.ee/wp-content/uploads/2015/03/Cogeca_Developments-of-agricultural-cooperatives-in-the-EU.pdf

11 http://epkk.ee/wp-content/uploads/2015/03/Cogeca_Developments-of-agricultural-cooperatives-in-the-EU.pdf
} 
(2016) where farmers consider investments and profit distribution issues, lack of trust and inadequate legislation as highly problematic within a cooperative.

Cooperatives exist in cereals and oilseeds, dairy, meat, but also in apple growing (e.g. Glogovi, Branitelj Eko, and Klaster Slavonska Jabuka), in cherries and other fruit (Milk - Agro, Buk, Cerine, Darđanka). In 2013 the association of garlic producers Slavonski češnjak was founded, which now has 300 members and covers a large part of the total garlic production. In the Neretva valley there is an Association of growers of mandarins 'MANDARINA' with 200 members covering $40 \%$ of the production. The number of cooperatives is increasing.

CCCE is the Croatian Centre for Cooperative Entrepreneurship (http://zadruge.coop/en/), which stimulates the development of cooperatives. The Centre has the status of a public institution that represents and coordinates the interests of cooperatives and cooperative alliances, monitors and analyses data in the field of cooperatives, proposes measures for their improvement, provides expert assistance to cooperatives and cooperative alliances, organises and conducts training and consultancy in the field of cooperatives, and is committed to the development of cooperative society as a whole.

The establishment of apple (and other fruit) growers association Slavonska Jabuka, which started growing apples on formerly arable land has greatly contributed to the increase in average yields of apples. They actively gathered knowledge in competing countries and pay specific attention to weather forecasting to protect the apple blossoms. Average yields of the Slavonska Jabuka orchards have significantly improved from 20 to 55-60 tonnes per hectare. The Neretva valley Association of Mandarin growers have established a PDO registration in 2015 of 'Neretvanska mandarina'. ${ }^{12}$ The registration is the result of a joint FAO/ EBRD project. With the support of Agrokor, and the Ministry of Agriculture, groups of farmers were organised, standards were created and the Geographical Indications (GIs) were officially registered, over the course of just three years. ${ }^{13}$ Until now, the PDO was not actually used in branding of products. Growers and traders have expressed their concern about the effectiveness of the initiative.

In many European countries, horizontal cooperation between farmers is aimed at creating countervailing power in the value chain and developing new ways of access to markets, sharing of risk, reduction of transaction costs, providing a better access to inputs, boosting innovation and quality improvement, and creating economies of scale (Bijman et al., 2012; Koopmans, 2006). These benefits are recognised by Croatian farmers as well, as shown in the study of Lončarić et al. (2016), where farmers associate cooperatives with better access to markets, acquisition of new knowledge and education, better information and assistance, and with easier access to financial compensations and subsidies.

In the interviews it was discovered that not all the initiatives of the cooperatives were evenly successful. The Neretvanska mandarina PDO was successfully registered, but using the PDO in the actual marketing of the mandarins was not yet successful. The Klaster Slavonska Jabuka mentioned that despite their quite successful growing achievements a major hurdle for the development of their marketing strategy is a lack of own cold storage. During harvest lots of produce is being offered to the wholesalers. Consequently, cooperation members receive relatively low prices. Without a shared cold storage the cooperative members do not have the ability to pool the production and prolong their selling season. Cooperation members trade with wholesalers individually. The wholesalers are able to cold store the produce and sell at times that prices are higher.

\section{Branch organisations: a need for empowerment}

Besides associations and cooperatives, the Croatian Chamber of Agriculture (HPK-CCA) represents the interests of its members. Their target group are all farmers in Croatia. Membership of the chamber is voluntary.

\footnotetext{
12 http://ec.europa.eu/agriculture/quality/door/registeredName. html?denominationId=11501

${ }^{13}$ http://www.ebrd.com/news/2013/croatian-food-products-win-geographical-indication-status.html
} 
HPK-CCA was established to promote, protect and represent the interests of CCA members, education and counselling of members of the CCA, providing support to members of the CCA for the purpose of improving agricultural production and rural areas, and to promote the value and importance of preserving and enhancing agriculture and rural areas in the overall socio-economic development of the country.

Another organisation of interest is the Croatian Young Farmers Association (HUMP). HUMP is aiming at creating conditions for increasing youth participation in agriculture and assisting in the use of new technologies, creating a positive atmosphere for entrepreneurship in agriculture, and strengthening cooperation with related organisations in Croatia and internationally. HUMP is quite effective in reaching their target group using non-conventional methods such as social media. According to HUMP, $9 \%$ of farmers in Croatia are under 40 . Moreover, HUMP aims at realisation and promotion of communication and dialogue between young farmers, scientists and the governmental authorities in Croatia and the EU. HUMP is active in a number of stakeholders' fora representing agricultural entrepreneurs which has a positive spill-over effect on the farmers outside HUMP's target group.

Despite of the efforts of existing interest groups, interviewees from the farming sector generally indicated that they see a lack of constructive dialogue between the national government and interest groups on the national level. Most farmers said that they do not experience a proper representation of their interests which could lead to a collective position and vision on the future of Croatian fruit and vegetables production.

\section{Vertical supply chain cooperation: large chain actors in the lead}

Large private enterprises from the agro-processing or agro-wholesale, often provide agricultural support services as a part of their business model, but, not less important, in order to secure their supply of raw materials. In the latter case, agricultural support is often accompanied by some sort of a supply agreement, or is a part of contract farming.

Some interviewed (larger) growers indicated to be successfully involved in developing packaging and production planning together with their buyers. Processing industry cooperates with supplying growers on production planning, packaging and product development.

In general, parties involved in fruit and vegetable supply chain management (volumes, improvement packaging, quality control, category management) in Croatia are large processors and wholesalers and supermarkets. In this perspective, being an integrated supply chain, Agrokor has a significant chain management role in the Croatian fruit and vegetables supply chain. Smaller growers have little, if any, involvement in supply chain management.

\subsection{Contracts and pricing: mixed practices}

In general, contracts between small growers and wholesalers and packers include volumes and quality. The contracts are usually renewed once a year. Prices are commonly set by buyers on a weekly basis. There is little to no actual negotiating of prices or volumes. This is the case for most of the cabbages, onions and garlic. Some contracts include the delivery of seeds or seedlings, fertilisers and other inputs to the growers, such as in the case of fruit delivered to AgroFructus or seedlings supplied to the tomato growers of Podravka. Some contractors also supply technical support and advisory services during the season. The prices of such inputs are then deducted from the payment. For smaller suppliers, contracts usually do not include predetermined agreements on volumes. They can call the wholesaler or packer and deliver their small batches to the local warehouses. The produce is then checked with respect to quality, and the buyer will check demand for the produce before buying from the small producer.

Larger producers usually have fixed one-year contracts with a number of buyers. In the case of integrated supply chains such as in the case of Agrokor and its production and retail subsidiaries, there may even be just one buyer. A small number of larger producers deliver directly to large retailers. Contracts then contain agreements on volumes, quality standards, packaging and delivery terms. Retailers usually set prices on a weekly basis or prices are negotiated on a day-to-day basis. 
This daily negotiation of prices increases transaction costs, which are compensated for by a decrease in the number of intermediary supply chain stages and associated handling costs and margins.

Wholesalers sell products to different customers on a daily basis. Framework contracts for e.g a year are settled with retailers and food service customers, usually containing agreements on quality, packaging and terms of delivery, sometimes prices. Some agreements on volumes exist although these are usually determined on a weekly basis in accordance to actual demand. In addition to these contracts, wholesalers sell additional amounts to retailers, other wholesalers and food service customers on a daily basis.

We do not have actual information on the prices paid by supermarkets to their suppliers. Some interviewees suggest that Konzum pays higher prices than other retailers. It is in fact known that Konzum actively promotes Croatian produce. There is too little information to verify the differences in prices across retailers and products. For some products it appears that Konzum is actually setting slightly higher prices. However, for other products it seems implausible that the retailer pays higher prices than its competitors as these competitors are delivered by the very same suppliers.

\subsection{Summary of structure, conduct, performance}

Table 3.2 below gives an overview of several elements of the structure, conduct and performance of the Croatian fruit and vegetable value chains. It is meant to be a summary of the findings on a number of indicators that collectively shed light on the performance of the value chain.

\section{Structure}

With regard to structure, it is most evident that downstream actors, i.e. processors, wholesalers and retailers are far more concentrated than upstream actors. In most sectors, primary producers of vegetables and fruit are very small and numerous. Three factors are important to mention regarding concentration and bargaining power at farm level:

a. In some of the studied products, there are a number of larger producers in addition to numerous smaller ones. In e.g. cabbages and tomatoes, the larger farms are the ones that have hundreds of hectares and do invest in new machinery, and sometimes market their own branded products.

b. Some of the larger companies are forwardly integrated in the supply chain by extending their activities into processing and distribution. E.g. larger cabbage farmers also invest in processing facilities, as shown in the example of Istrian cabbage producer Ciburiprodukt. ${ }^{14}$

c. In some sectors, like in cabbages, mandarins and apples, cooperation between farmers exist. Cooperation between individual farmers might increase bargaining power and market access to a certain extent. Working together produces also other benefits, like increasing efficiency on storage and transport, and reducing costs of production and marketing. Cooperation to achieve economies of scale can be increased in almost all fruit and vegetables production sectors.

In general however most farmers still lack volumes in the market that would genuinely improve market access and strengthen their bargaining power.

In some sectors, where processing plays an important role, like tomatoes, cabbages and cherries, the relative bargaining power of the farmers is further reduced by the existence of one or a few large processors. Farmers have virtually no influence on the contract prices that the processors offer. The effect of the relatively small size of farmers (or the concentration in the other parts of the chain) is that farmers do generally not make enough profit to invest in improving their business practices. Improving farm profits can be achieved by cooperation, by restructuring farms (increasing the average farm size, and land reform), by improving farm management by education and extension services, and by investing in better farm equipment and inputs.

\footnotetext{
${ }^{14}$ See https://www.total-croatia-news.com/made-in-croatia/11671-istrian-king-of-cabbage-conquering-european-markets
} 
The distinction between the fresh product market and the processing market is important in the sense that in most cases a contract will be drawn up between the farm and the processor, and the farm produces a certain type of product (often seeds are provided by the processor) and sells everything to the processor at a fixed or non-negotiable price. Processors increasingly integrate backward into farming and source from their own land; demand for processing fruit and vegetables is high and processors want certainty regarding quantity and quality.

Some Croatian fruit and vegetables are really differentiated from produce from other countries in terms of product characteristics. Croatian mandarins, sour cherries, garlic, and cabbages have distinct characteristics, some of which are recognised as such in EU quality labels. The true value of these distinct characteristics (product differentiation) must however still be revealed in the market. There seems to be a preference for locally grown produce in Croatia and it certainly is appealing to tourists. However, a good product alone is not enough to sell at a good price; it requires additional investment in post-harvest processes and marketing to realise the full value of that the product can offer.

Entry and exit barriers are considered to be a negative or hampering factor in the development of the sector. Although the number of farmers is decreasing, in practice there are still many unprofessional small farmers in the sector. These farmers cannot make a proper living from their activities, and limit the overall quality of the Croatian product and efficiency of the supply chain. Exiting the sector would free up land for other farmers to grow, and also decrease supply of lower quality produce. In other parts of the supply chain, farmers entering the market is more of a problem than too few exiting. Although in the retail sector, a number of foreign supermarkets have entered the market in the past two decades, concentration is increasing and the investments needed to enter the market are very high.

A positive aspect of the structure of the supply chains is the overall growth of demand, from tourism and local consumption, as well as export demand. Demand for Croatian produce is expected to grow, provided that appropriate marketing strategies are developed to cater to the various market channels. Market demand and the tourism market are discussed further in Chapter 5.

\section{Conduct of the supply chain actors}

Vertical cooperation is more developed than horizontal cooperation among the individual actors. However, it might be argued that the vertical cooperation that is meant here is mostly orchestrated from the side of the processors, wholesalers and retailers. True cooperation in which farmers are equal partners is rare. Although there are some good examples of horizontal cooperation in e.g. garlic and apples, they generally represent just a small part of the farmers. In mandarin production there is a cooperation of farmers, but the cooperation has not been very successful in exploiting the registered PDO for its mandarins yet. Horizontal cooperation is not very well developed in Croatia. Despite some good examples of cooperatives, the number of cooperatives and producer organisations is limited. Existing organisations indicate that it is often difficult to get farmers to join in sufficient numbers and after the establishment of the organisation it is often difficult to really implement plans and get sufficient support from members. This is to some extent a cultural factor where trust in cooperatives is generally low. On the other hand it may also have to do with existing structures and dominant position of existing firms in which new cooperatives have to establish themselves. The current breakup of Agrokor could be a chance for new (cooperative) firms to establish a position in the market.

In terms of relations between supply chain actors, it is evident that - as a result of the long dominance of Agrokor and the existence of leading processing firms in some sectors - in general medium to longterm contracts (of at least a year) exist in many sectors. Farmers can in this way rely on finding a buyer at least. In general there seems to be a fair level of trust in the good intentions of the other chain partners. Current financial turmoil and troubles at Agrokor have however shaken up chain relations quite a bit. Payment terms are excessively long, in many cases up to 60 or even 120 days. This has serious implication for the financial stability of many firms in the chain and their ability to invest.

Quality standards are not yet widely implemented at farm level. Especially for small farmers, getting certified (e.g. GLOBALG.A.P.) is a hurdle to take. But as larger farms are gradually becoming certified and imports are too, the distance between small and large farms is increasing. In the end, both in domestic supermarkets, export markets, as well as in most food-services markets (hotels, restaurants, catering), quality standards will be important. 
Product development and marketing (including branding and labelling) are not very well developed at the farm level. Often this role is taken up by wholesalers or processors. Labelling products as 'Croatian' is not enough anymore to compete in the (international) supermarket channel. Produce competes with other products, new products are being offered in the market almost daily. Successful marketing includes not only the product (quality), but also offering the product at the right moment to the right customer, with the right promotion and price. Retail buyers look at freshness, taste and look of course, but also to price, availability in terms of sufficient volumes, adherence to certain certification schemes, and general business practices.

\section{Performance}

The performance of the Croatian fruit and vegetables sector is not very good at the moment. Although profits of some of the farms that we have spoken to have not been too bad in recent years, due to good demand conditions, most farmers make low or negative profits. Due to the structural problems mentioned and the conduct of actors that partly follows from the structure, yields are generally lagging behind those in competing countries. This should be a first concern: to improve yields and productivity at farm level.

With the exception of mandarins and sour cherries most of the studied products are facing quite a bit of competition from imports even in the season. Exports are very limited. Only mandarins are exported in significant quantities, mostly to neighbouring countries. The quality of the products is generally judged as good by the farmers and other supply chain actors, although it has also been said that smaller farmers have difficulties adhering to quality standards demanded in the market. It should also be noted that quality is a relative concept; what may be considered a good-sized apple in Croatian supermarkets, may be considered too large in other countries. Innovation is key to improving the value of Croatian fruit and vegetables throughout the supply chain. With the exception of some of the larger processors, innovation in the sector is driven by the efforts of just a small number of entrepreneurs. 
Table 3.2 Summary of the value chain analysis for selected products a) (scores: ++ very high + high 0 medium - low -- very low, or ++ very good + good 0 neutral - bad -- very bad na not applicable)

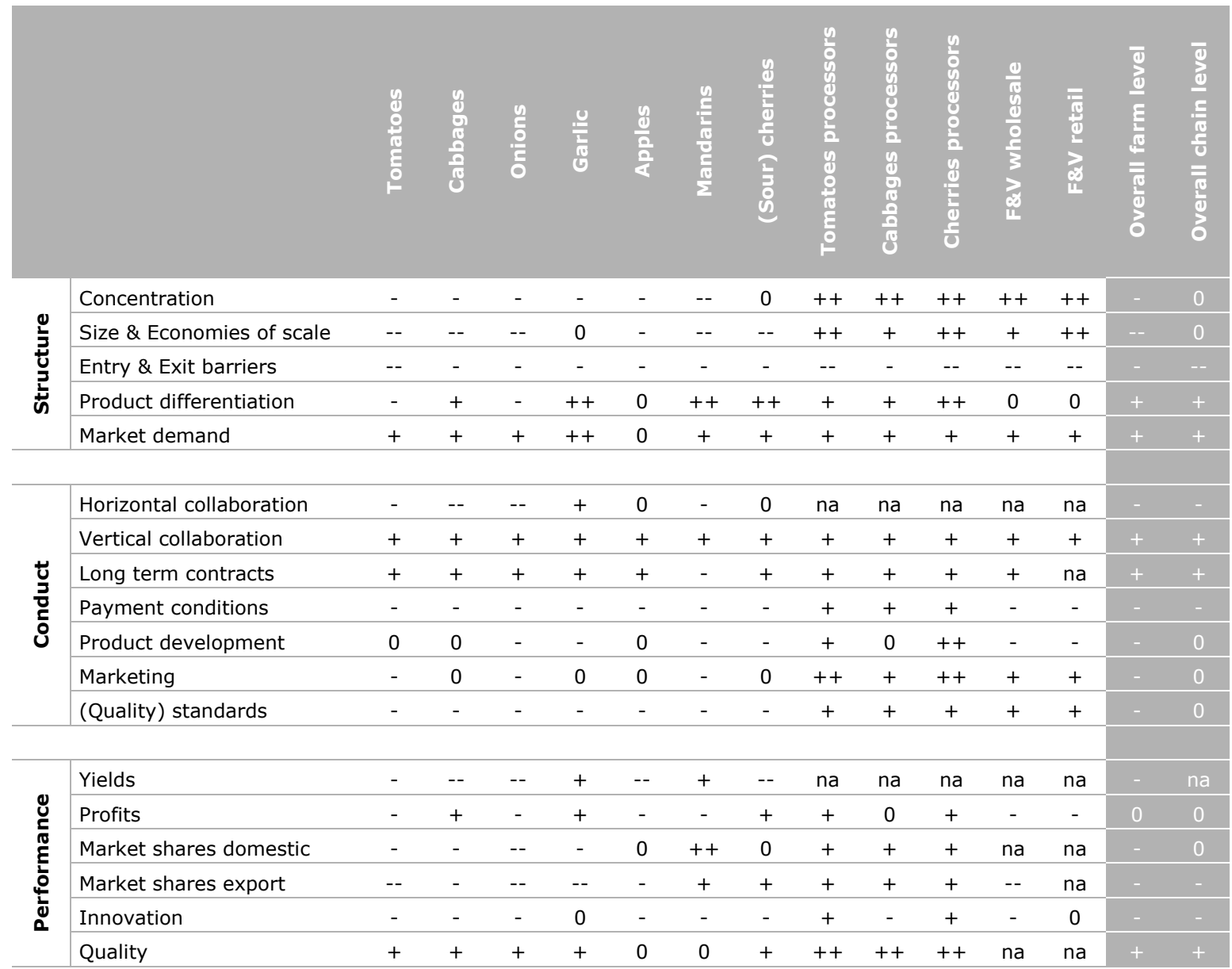

a) The relative scores are determined on the basis of available quantitative data and the information from the interviews. They are meant to give an idea of the entire product chain or sector, and we acknowledge that there are large differences between individual companies or segments such as different product segments, or market channels (e.g. fresh market versus processing). One or two plusses (+) indicate a (very) high or (very) good value, while a negative (low or bad) value is indicated by one or two minuses (-); 0 indicates an average or neutral value of the indicator. 


\section{$4 \quad$ Business environment}

\subsection{Introduction}

In this study the business environment is described on the basis of four themes (Inspired by Porter's Diamond model, Porter 1990):

- Climate, labour and land

- Economic and business climate

- Related and supporting industries

- Enabling environment.

See also Appendix 6 for the general Country profile of Croatia.

\subsection{Climate, labour and land}

\section{Favourable climate conditions}

Croatia has good climatic conditions for agriculture. There are three different geographical and climate areas:

1. lowlands in the north and east, influenced by continental climate

2. coastal area in the south influenced by the Mediterranean climate, and

3. the mountain region in the so called Gorski (mountain) part of Croatia.

The various types of climates, relief and soil enable the production of a wide range of agricultural products, from agricultural and industrial crops to vineyards and continental and Mediterranean fruits and vegetables. There are conditions for cultivation of almost all most popular household food products.

The Northern part of Croatia (Pannonian region) covers approximately $47 \%$ of total country area and $64 \%$ of total Croatian population. It is the area with a continental climate and sharply defined seasons. The soil, climate and the favourable yearly circulation of precipitation gives this area a good natural potential for an efficient agricultural production.

In spite of good climatic conditions growers are confronted with risks like hail, frost or drought. In addition, climate change is expected to negatively affect the conditions in the future. The expected impact of climate change includes 'the increase of average annual temperature and probability of droughts in summer followed by water shortage of $30-60 \%$ in relation to the present situation, as well as in occurrence of extremes regarding quantity, schedule and intensity of precipitation, air and soil temperature, wind power, hails, etc.' (Ministry of Environmental Protection, 2014, p.144). ${ }^{15}$ Some of the interviewed growers said already to experience the impacts of climate change, such as more extreme temperatures during the growing cycle (more differences between high and low) and, as a result, lower yields.

\section{Families run the farms, challenges in attracting labour}

Most of the Croatian population lives in the northern half of the country, with approximately a quarter of the population residing in and around the capital of Zagreb. The urban population is $59 \%$ of the total population (2015). The unemployment rate in Croatia decreased to $10.9 \%$ in August of 2017 from $13.1 \%$ a year earlier, but is still higher than the EU-28 average of July. The EU28 unemployment rate was $7.7 \%$ in July 2017 , down from $8.5 \%$ in July 2016 . In Croatia, employment rates in thinly

$\overline{15}$ http://unfccc.int/files/national_reports/annex_i_natcom_/application/pdf/hrv_nc6.pdf 
populated, intermediate and densely populated areas are very similar, with differences of only 2 percentage points (higher in densely populated areas).

According to Eurostat figures of 2016, average hourly labour costs in the EU28 for all sectors, but excluding agriculture and public administration (no data available for agriculture) were estimated to be $€ 25.40$. There are differences between the EU member states. The lowest average hourly labour costs are in Bulgaria ( $€ 4.40)$ and the highest in Denmark (€42.00). Croatia ( $€ 10.00)$ ranks 21 th country with almost a third part of the average labour costs in the Euro area. However, labour costs in Croatia increased more rapidly $(+45 \%)$ than the EU28 on average $(+30 \%)$ between 2004 and $2016 .{ }^{16}$

According to the EU labour force survey of Eurostat, 224,000 persons aged over 15 are employed in crop and animal production, hunting and related activities in Croatia in 2010. This accounted for $13 \%$ of total persons employed. In 2016 the number dropped to 101 thousand persons, or $6 \%$ of total employed population (Eurostat). This is a huge decline compared to the EU28 average. In the EU, the share of persons employed in crop and animal production, hunting and related activities increased from $4 \%$ to $6 \%$ between 2010 and 2016 (Eurostat).

Eurostat's farm structure survey shows that farming in Croatia is very much a family affair; on average $94 \%$ of the labour input for agriculture (measured in annual work units) was carried out by the farmer and/or a member of his/her family in 2013. This was a higher proportion than the average for the EU-27 in 2013 (83.4\%) (Eurostat).

The numbers from Eurostat above show that there are some serious challenges in attracting or keeping people working in farming sector. First, rural areas faced an intensive outgoing migration of the population due to the fact that many surface areas were under land mines and low profitability of production on small-scale plots on the remaining farms. Second, farm work still suffers from a negative image in Croatia. Agricultural work is often associated with hard work and low payment. Agricultural has to compete with other sectors for labour. The interviewees from the Adriatic coastal regions indicate difficulties with getting workers during harvest season. People prefer to work in the expanding tourism sector, because they get better wages and have better work image. In the Northern regions, during the harvest season, growers have to compete for labour with better paying farms abroad. The interviewees indicate that seasonal work is hard to organise with workers from other regions, or from outside Croatia, where labour is available. The necessary temporary living facilities for these workers are too expensive.

Concerning education, Croatia is doing well with a Primary completion rate (2015) of $100 \%$. Also its net enrolment of secondary schools (2015) gives a high percentage of 92 . The gross enrolment rate of tertiary schools (2015) is 69\%. Yet, the quality of the education system - the degree in which the education system meets the needs of a competitive economy - is low. In the Global competitive report of the World Economic Forum (2017) Croatia ranks a $96^{\text {th }}$ place out of 137 selected countries. Good education affects succession because children choose for studies with good perspectives for their future. If there is no successor, farms are split up and farming becomes a side-line.

\section{Water is available, but not always accessible}

Croatia is rich in water. Only a small part of agricultural land requires irrigation and is covered by some kind of irrigation system. Freshwater resources per inhabitant are considered an important indicator for measuring the sustainability of water resources. According to Eurostat water statistics report in 2017, Croatia has the highest freshwater resources (over 27 thousand $\mathrm{m}^{3}$ yearly per inhabitant) measured as a long-term average with a minimum of 20 years. ${ }^{17}$ Finland and Sweden follow with around 20 thousand $\mathrm{m}^{3}$ yearly per inhabitant. By contrast, relatively low levels - below 3,000 $\mathrm{m}^{3}$ per inhabitant - were recorded in the six most populous EU Member States (France, the United Kingdom, Spain, Germany, Italy and Poland.

\footnotetext{
16 http://ec.europa.eu/eurostat/statisticsexplained/index.php/File:Labour_costs_per_hour_in_euro,_whole_economy_(excluding_agriculture_and_public_administr ation)_T1.png

17 http://ec.europa.eu/eurostat/statistics-explained/index.php/Water_statistics
} 
Nevertheless, the interviewed small growers indicate that getting access to the water sources for setting up new irrigation systems is time-consuming due to bureaucracy. Moreover, small fruit and vegetable growers often work on different widespread plots. These growers have indicated that they often need a permission from the (regional) authorities to develop basic water supply, like a well, sometimes for each lot individually. In some cases growers indicated that they had to pay a fine afterwards due to changes in legislation about water supply. Efficient construction of irrigation facilities on small land plots is often dependent on the inventiveness of a grower. In general, larger established growers have better access to water and have often modern irrigation facilities

\section{Agricultural land: segmentation and underuse}

According to Eurostat data of 2015 , the total utilised agricultural area was $1.5 \mathrm{~m}$ ha, divided into arable land (54.8\%), permanent grassland (40.2\%) and permanent crops (4.9\%) (see Table 4.1). In 2013, Only $1.1 \%$ of the utilised agricultural area (UAA) is irrigated - substantially less than in all other Mediterranean countries in the EU. ${ }^{18}$ More than $83 \%$ of the agricultural area is located in the continental part of the country. Here, arable land dominates, with more than three quarters of the UAA, followed by permanent grassland (18\%). The coastal area contains slightly less than $17 \%$ of the agricultural land, $65 \%$ of which is covered by permanent grassland. Permanent crops account for $17 \%$ of UAA in the coastal region.

Table 4.1 Agricultural land in Croatia and EU28

\begin{tabular}{|c|c|c|c|c|}
\hline Indicator & Croatia & $\begin{array}{r}\text { Jadranska } \\
\text { Hrvatska }\end{array}$ & $\begin{array}{r}\text { Kontinentalna } \\
\text { Hrvatska }\end{array}$ & EU28 \\
\hline Land area, square km, in 2015 & 56,594 & 24,705 & 31,889 & $4,463,600$ \\
\hline Utilised Agricultural area, 1,000 ha, in 2015 & 1,538 & & & 178,779 \\
\hline o.w. Arable crops, in \% & 54.8 & & & 59.8 \\
\hline Permanent grassland, in \% & 40.2 & & & 33.2 \\
\hline Permanent crops, in \% & 4.9 & & & 6.6 \\
\hline
\end{tabular}

Source: Eurostat.

Croatia's agricultural development has been strongly and negatively affected, not only by structural changes following the break-up of the former Republic of Yugoslavia (50\% of land was previously farmed by large, vertically and horizontally integrated agricultural holdings), but also by major demographic changes caused by the war.

Note that in the Mediterranean and mountainous regions of the country today more than half of the useable agricultural land area is not regularly cultivated. There are many reasons for this and among the most relevant is the fact that many surface areas were under land mines.

Second, with the independence of Croatia from Yugoslavia in 1991 and the institution of the Law on Agricultural Land in the same year, formerly society-owned land became state-owned land. Since then several new laws have been passed that aim at improving the structure of agricultural land by disposal of state-owned land by sale, lease, concessions, or return to former owners. Since then, the share of state owned land has decreased.

Family farms cultivate approximately two thirds of the total agricultural land while the remaining third is state-owned. The private share of arable land is slightly larger (approximately $75-80 \%$ ). The slow process of privatisation of state-owned agricultural enterprises has contributed to create large areas of uncultivated agricultural land.

Farmers experience problems in buying big surfaces of land (serried plots) to produce efficiently. Not only does the government lease ${ }^{19}$ (and therefore also no EU grants can be obtained) but also small producers (especially in popular areas for tourists) wait to sell their lot for highest price to tourism investors.

\footnotetext{
${ }^{18}$ See https://ec.europa.eu/agriculture/sites/agriculture/files/statistics/rural-development/2013/ch2_en.pdf

19 The 1991 Law on Agricultural Land
} 


\subsection{Economic and business climate}

\subsubsection{Positive economic trends}

Between 2000 and 2008 Croatia experienced economic growth with yearly growth between 3 and $6 \%$. (Source: The World Bank). In 2009, as a result of the economic crisis, GDP dropped by $7 \%$ in one year. Between 2010 and 2016 GDP growth varies between $-2 \%$ and 4\%. Still, GDP per capita (current US\$) has grown with $133 \%$ between 2000 and 2016. The Croatian consumer market became increasingly more attractive to new businesses (see also Section 3.6).

Still, on average, Croatian consumers spend a relatively large part of their budget on food (29.5\% compared to $12.4 \%$ in the EU-28 in 2014) (Eurostat and Croatian Bureau of Statistics, Household survey 2015). ${ }^{20}$ In addition all the interviewees mentioned that Croatian consumers are in general relatively price sensitive when it comes to buying food. When the margins of other supply chains actors are tight, local growers will experience pressure on their prices, which will leave only the more efficient growers in the market.

For a substantial number of growers, the financial problems of Agrokor, as a large agri-food player, result in delayed payments, affect the cash flow on farm level and lead to disability to invest.

Diversification in buyers markets, including exporting, leads to opportunities in risk diversification.

When focusing on domestic market segmentation, some successful sales strategies have been applied on the Croatian consumer market. For example, Croatian consumers have preference for locally grown products. When prices are equal, Croatian consumers will choose for Croatian fruit and vegetables as it has a better image. This is an opportunity for efficient Croatian fruit and vegetable suppliers on the Croatian retail market.

Another successful market niche is organic. The number of organic farms in Croatia is increasing. However the sales of organic on the Croatian market are still relatively small, some interviewees for this study indicated large yearly growth numbers of sales of organic products. This brings opportunities to growers that are considering to switch to organic production. The organic logo turns out to be a powerful marketing tool in Croatia, but also in the EU as a whole.

\subsubsection{Rise of tourism}

Tourism is a large sector in Croatian economy, covering $18 \%$ of the total economy in 2015 (Tourism in figures, Ministry of Tourism 2016). In 2016, the income generated by tourism was nine times the income generated in 1995, which shows a tremendous growth of the sector (see Table 5.1). Croatia has set out a national strategy for tourism with an expected effect of bringing the revenue from tourism to $€ 14.5 \mathrm{bn}$. by 2020 . The growth of tourism brings opportunities to all its supplying sectors, including agriculture and food.

Table 4.2 Inbound tourism in Croatia, $€ b n$

\begin{tabular}{lrrrrrrrrrrr} 
& 1995 & 2000 & 2005 & 2010 & 2011 & 2012 & 2013 & 2014 & 2015 & $2016 *$ \\
Inbound tourism in Croatia, bln. euro & 1.0 & 3.0 & 5.9 & 6.1 & 6.7 & 6.8 & 7.2 & 7.4 & 8.0 & 8.7 \\
\hline
\end{tabular}

Source: UNWTO, 2016 http://www.e-unwto.org/doi/pdf/10.18111/9789284418930

Next to Zagreb as the country's capital, most tourist destinations are concentrated in the regions along the Adriatic coast. The tourism peaks during the high season (summer), which leads to the increase of food consumption in Croatia especially in that period. According to the Croatian Ministry of Tourism (based on the 2015 study carried out by the Croatian Chamber of Commerce (HGK)) Istria County experienced a fivefold growth of food consumption during the height of the tourism season

\footnotetext{
${ }^{20}$ Eurostat nama_10_co3_p3
} 
compared to the low season in that year. Other counties along the Adriatic coast show similar numbers. ${ }^{21}$ According to Leko Šimić and Pap (2015) $25 \%$ out of the average daily expenditure of tourists is on food (based on Institute for Tourism 2010 data).

There are no data available about the share of domestic fruit and vegetables in the tourist consumption patterns. However, the study of Leko Šimić and Pap (2015) (based on the HKG 2015 study) indicates that in hotels in Croatia about $50 \%$ of the fish, lamb meat and pasta consumed by tourists were locally produced, while these products are known as a part of Croatian cuisine (Leko Šimić and Pap, 2015).

Leko Šimić and Pap conclude that there are great opportunities in the improvement of promoting the existing high quality products, especially of local food consumed by tourists or bought as food souvenirs. Based on the analysis of Leko Šimić and Pap (adapted from Leko Šimić and Hrenek (2015)), the following actions can be developed for the positioning of food as a high value added component of the Croatian tourism product:

1. Improving the coordination in the food marketing system in tourism;

2. Improving the quality of laws and regulations regarding local food supply in tourism;

3. Improving the quality of promotion of local food in tourism;

4. Increasing financial support for food projects in tourism;

5. Organising food events;

6. Making food information available for tourists;

7. Increasing the quality offer in hotels and restaurants in general;

8. Increasing the quality of local food products;

9. Increasing availability of local food products;

10. Attracting tourists' interest;

11. Attracting local food suppliers' interest.

Improving existing regional supply chains of domestic products and designing of new supply chains for tourism is necessary for improving the quality and availability of products for tourism. Although local supply chains may be short, they are not necessarily less complicated than global supply chains. Organising the efficient and safe supply chain processes that are necessary to supply to quality restaurants and hotels requires professionalism throughout the chain, and cannot easily be organised by farmers alone. The involvement of other actors in the supply chain and (government) stakeholders is crucial as small farmers/boutique hotels cannot set up a chain alone. E.g., one of the important issues that has to be addressed is food safety control.

\subsubsection{Adequate general business climate}

According to the World Bank's Doing Business indicator (2017), the overall ranking for Croatia is 43 out of 190 . This means the regulatory environment is conducive to the starting and operation of a local firm. Nevertheless Croatia dropped 4 places compared to 2016. 'Starting a business' and 'Dealing with construction permits' are particularly troublesome for (foreign) investors. Croatia made starting a business more difficult by increasing notary fees. Compared to Croatia's finest competitors on selected products (see Appendix 2) differences on especially these two topics can be large. On the other hand, compared to neighbour country Italy, Croatia performs better on the overall score (see Table 5.2).

\footnotetext{
${ }^{21}$ See www. mint.hr/default. aspx?id=41709 (Accessed on: September 2017)
} 
Table 4.3 Ranks of 'doing business' indicators (rank $1=$ best, $177=$ poorest), for selected countries in 2017

\begin{tabular}{lrrrrrrrrrr} 
& Croatia & Austria & Poland & Netherlands Slovenia Spain Hungary Serbia Italy China \\
Overall & 43 & 19 & 24 & 28 & 30 & 32 & 41 & 47 & 50 & 78 \\
\hline Starting a business & 95 & 111 & 107 & 22 & 49 & 85 & 75 & 47 & 63 & 127 \\
\hline Construction Permits & 128 & 49 & 46 & 87 & 80 & 113 & 69 & 36 & 86 & 177 \\
\hline Getting electricity & 68 & 20 & 46 & 45 & 16 & 78 & 121 & 92 & 51 & 97 \\
\hline Registering Property & 62 & 30 & 38 & 29 & 34 & 50 & 28 & 56 & 24 & 42 \\
\hline Getting Credit & 75 & 62 & 20 & 82 & 133 & 62 & 20 & 44 & 101 & 62 \\
\hline Protecting Investors & 27 & 32 & 42 & 70 & 9 & 32 & 81 & 70 & 42 & 123 \\
\hline Paying Taxes & 49 & 42 & 47 & 20 & 24 & 37 & 77 & 78 & 126 & 131 \\
\hline Trading Across Borders & 1 & 1 & 1 & 1 & 1 & 1 & 1 & 23 & 1 & 96 \\
\hline Enforcing Contracts & 7 & 10 & 55 & 71 & 119 & 29 & 8 & 61 & 108 & 5 \\
\hline Resolving Insolvency & 54 & 20 & 27 & 11 & 12 & 18 & 63 & 47 & 25 & 53 \\
\hline
\end{tabular}

Source: The World Bank, Doing Business.

Furthermore Croatia performs moderately on the Corruption Perception Index (CPI) of Transparency International, which ranked it 55 out 176 countries.

\subsection{Related and supporting industries}

\section{Further development of technology and ICT}

Advanced technology for fruit and vegetable production is available from mainly foreign providers (e.g. machinery from Spain for garlic production or Italian and Spanish technology for mandarins, watermelons and cabbage) but costly. The unequalled economy of scale for the majority of farms (predominantly self-sufficient production, limited capacities, lack of production specialisation) leads to an inadequate production structure, low yields in the majority of farms. This is among other things due to the lack of use of adequate production technologies, old machinery, primitive storage, lack of cold storage facilities, other equipment, lack of irrigation or drainage systems.

According to an article from 2017 of Export.gov (the US government export agency) (data based on various sources from Croatian government and businesses), ${ }^{22}$ Croatia accounts for around $40 \%$ of IT spending from all countries in the Adriatic region, with Slovenia and Serbia being $2^{\text {nd }}$ and $3^{\text {rd }}$ countries in terms of spending on IT.

'The Croatian IT sector grew at an average rate of 6\% in the period 2012-2016. The Croatian telecommunication sector is one of the most developed sectors of the Croatian economy. Relying heavily on EU funds, the Croatian government plans to invest about $\$ 250 \mathrm{~m}$ each year through 2020 to continue their investment in the construction of next generation broadband and ICT development in rural areas. It is estimated that by 2020 , fifty percent of the population will have ultra-fast access to the internet' (Ibid, 2017).

Farmers can benefit from ICT development in rural areas in improving their farming techniques. As shown from their counterparts elsewhere, precision farming can boost yields, and can be particularly beneficiary for smaller farms. ${ }^{23}$

\section{Large share of renewable energy and good road infrastructure}

The dependency on import of energy is decreasing in the last years. ${ }^{24}$ Over $50 \%$ of energy production concerns renewable energy. Croatia satisfies its electricity needs largely from hydro power plants. This

\footnotetext{
${ }^{22}$ Available on https://www.export.gov/article?id=Croatia-Information-and-Communication-Technology (Accessed on: September 2017)

${ }^{23}$ See for example CGAIR research programme results https://wle.cgiar.org/thrive/2017/03/20/precision-agriculture-biggeryields-smaller-farms
} 
is the main energy source in Croatia followed by $33 \%$ dependency on natural gas. Croatia has its own very limited natural gas and oil sources. ${ }^{25}$

The World Economic Forum's survey on the quality of transport infrastructure shows a good result for Croatian road infrastructure, but relatively low marks for its railroad and air transport infrastructure. Croatia also ranks relatively low when it comes to timeliness of shipments. The completion of the Trans-European transport networks in Croatia $^{26}$ is below average for all modes of transport.

\section{Raw materials and inputs available}

Raw materials (seeds, cuttings, fertiliser, pesticides, substrates, etc.) can be bought at domestic providers like AgroFructus Group, but also from foreign suppliers (like multinational companies providing fertilisers and seeds) through local representatives. Everything is available but relatively expensive according to the interviewed growers. For fertilisers, domestic company Petrokemija has a large but declining share in supplying the agricultural sector. The company has to compete with other companies for inputs while unlike large multinationals from other countries it possesses no domestic or otherwise owned mineral resources. In the short run this would not endanger the supply of good fertilisers, while in the long run it might be important for Croatian growers to have access to a wellestablished local supplier next to foreign companies. The advantages of local companies might not be in their cheap prices, but in the other investments that they do in the supply chain and the local economy in general, e.g. in infrastructure and collaborative research.

\subsection{Enabling environment}

\section{Government: a significant role in the future of agriculture}

An article of Lončarić et al. (2016) where farmers' attitudes on several agriculture related issues are studied. Slow administration, poor cooperation with the Ministry of Agriculture and local government, small and irregular subsidies were among most significant government-related problems of Croatian agriculture. Among government-related problems with cooperatives, inadequate legislation is perceived by farmers as most problematic. In general, government, extension service and farmers themselves were perceived as entities, which can improve the situation in agriculture (Lončarić et al., 2016).

In the area of land reform there are new promising structural developments. In 2013 the new Agricultural Land Act was passed and in 2015, the Act on the Agricultural Land Consolidation had been passed. The latter Act is developed as a legal basis for re-enforcement of land consolidation in Croatia for the first time after Croatia's independence. The Act is aimed at removing one of the biggest obstacles of the agricultural production in Croatia. These acts introduce a new concept of a mechanism for land consolidation, which is meant to bring a major step forward in the process of land consolidation and improve agricultural efficiency. It is yet to be seen which results are finally achieved, but nevertheless this is a move in the good direction to remove one of the major obstacles to competitiveness of Croatian agriculture.

Most growers and associations that were interviewed said to experience that after the EU accession, the Croatian fruit and vegetables growers are left in a market situation where the forces are largely unequal. The most heard complain in this perspective was about a lack of support from the government. The interviewed growers and other supply chain actors further mentioned the absence of any forward looking plans and prospective for the Croatian fruit and vegetable sector and do not see any direction provided by the government. Therefore, it is advised that the government, in

\footnotetext{
${ }^{24}$ See: http://ec.europa.eu/eurostat/statistics-explained/index.php/File: Net_imports_of_primary_energy,_20052015_YB17.png

25 See: http://ec.europa.eu/eurostat/statistics-

explained/index.php/File:Energy_production,_2005_and_2015_(million_tonnes_of_oil_equivalent)_YB17.png

${ }^{26}$ The Trans-European Transport Networks (TEN-T) are a planned set of road, rail, air and water transport networks in the European Union. The TEN-T networks are part of a wider system of Trans-European Networks (TENs), including a telecommunications network (eTEN) and a proposed energy network (TEN-E or Ten-Energy
} 
collaboration with the actors in the supply chain, and research and education, develops a long-term vision for the Croatian fruit and vegetable sector by making choices, and creating focus and clearness.

\section{Food safety and quality: high standards required}

The Food Act is the basis framework law on food safety in Croatia. The Food Act has transposed and implemented Regulation (EC) No 178/02 and covers a general overview and requirements on food and feed safety. In the context of fruit and vegetables, the Food Act, national regulations and transposed and implemented EU regulations control such issues as obligations of food business operators and general requirements relating to food, primary production, processing, facilities, handling of fruit and vegetables products, laboratory testing, labelling of fruit and vegetable food products, and import or export. Residue risks for consumers on Croatian market are generally low. A study from 2014, carried out by Sanja Miloš et al. (2014), assessed the acute exposure of consumers from pesticide residues in products that can be found on Croatian market. The assessment was performed based on surveillance (monitoring) results of pesticides in products on market in Croatia for the years 2007, 2008, and 2009. Samples, domestic and imported, belong to the category of fruits, vegetables, cereals and their derivatives. It was concluded that acute risk for consumers in Croatia can be considered rare, except for oranges and lettuce with high concentrations of pesticides for all consumers groups, especially for children.

The interviewed supply chain actors consider the Croatian food safety control system as strict, but in general not obstructive to their business. However, the interviewed growers indicated that in Croatia, disregarding maximum allowed residue levels for pesticides for once will bring huge risks to their market position in the future as their buyers will be reluctant from buying from them again.

When considering export to other EU countries, farmers face buyers in other member states having standards which are stricter than the maximum residues laid down in the EU legislation. Most supermarkets have their own standards (codes of practices) regarding pesticides, which are stricter than legislation.

The most commonly requested extra-legal food safety certification scheme which is relevant for fruit and vegetables, is GLOBALG.A.P. GLOBALG.A.P is a pre-farm-gate standard that covers the whole agricultural production process, from before the plant is in the ground to the non-processed product (processing not covered). GLOBALG.A.P. has become a minimum standard for most European supermarkets. As understood from the interviews, starting from 2018 all large supermarket chains in Croatia will require GLOBALG.A.P or similar scheme certificates from their suppliers. However, to be able to sell on the Croatian domestic green market, there is no need to obtain any GLOBALG.A.P yet.

Interviewed Croatian businesses that are active on the export market have been already working with GLOBALG.A.P. Others are preparing for its implementation. Some growers indicated to be reluctant toward GLOBALG.A.P as the certification involves immediate investments, their resources are lacking, and the (financial) benefits of such a certification are not clear for them yet.

Fruit and vegetable products have to at least comply with the EU marketing standards. For some products such as citrus fruit, apples and tomatoes there are specific EU marketing standards. ${ }^{27}$ However, there are differences in marketing standard quality required by different buyers on the Croatian market. E.g. a product batch can be rejected due to not fulfilling a certain marketing standard of a buyer in terms of product appearance. In such a case, it can be frustrating for some growers to have their products rejected as they see a good product quality differently, e.g. in terms of product taste instead of appearance. Improving crop quality management at farm level, or choosing the appropriate segment that coincides with products' quality are two strategies that both involve becoming familiar with buyers preferences and building trust with buyers.

\section{Agricultural education and extension services: fit for the future?}

Innovation is particularly important for economies as they push the frontiers of knowledge, and the possibility of generating more value by merely integrating and adapting exogenous technologies tends

\footnotetext{
${ }^{27}$ See https://ec.europa.eu/agriculture/fruit-and-vegetables/marketing-standards_en
} 
to disappear. In these economies, firms must design and develop cutting-edge products and services to maintain a competitive edge and move toward even higher value-added activities. This progression requires an environment that is conducive to innovative activity and supported by both the public and the private sectors. In particular, it means sufficient investment in research and development (R\&D), especially by the private sector; the presence of high-quality scientific research institutions that can generate the basic knowledge needed to build the new technologies; extensive collaboration in research and technological developments between universities and industry; and the protection of intellectual property.

There are four agricultural faculties in Croatia (with BSc, MSc and PhD programmes). In addition, higher education is provided by a number of colleges (BSs). Furthermore, vocational training is provided at agricultural schools. The World Economic Forum's survey on the quality of Innovation shows unfavourable results for Croatia, particularly on the University - industry collaboration in R\&D (to what extent do business and universities collaborate on research and development). In the comparison of 138 countries worldwide Croatia is ranked $114^{\text {th }}$.

Croatia has a national extension service for agriculture, a public service body, which had been established after the country's independence and went through a few organisational changes. The latest Law on Agricultural Advisory Service is from 2012 and has undergone some amendments in 2013 through the Law on Changes in the Agreement on Agricultural Advisory Service. ${ }^{28}$ Among the objectives of the Advisory Service is farm assistance in issues like technology expertise, development plans for agricultural holdings, implementation and participation in IPARD programmes and other support measures, cooperation between farmers, institutions, companies and individuals. A 2015 study by Zondag et al. (2015) for the European Commission, about young farmers' needs in Croatia shows that the extension service is considered as an important source of information for young farmers. At the same time, the focus group members of the study are of the opinion that the public extension service in Croatian agriculture should be organised in a better way and the system should give the public extension service more power and importance. Lončarić et al. (2016) show that farmers consider extension service as one of the key entities, which can improve the situation in agriculture. The interviewees for the present study confirmed that the extension service cannot always adequately respond to the needs of farmers. The interviewees suggested an assessment of information needs at farm level and adaptation of the assessment results by the service in its work structure.

\section{Finance: high interest rate and collateral}

According to the interviewed growers, getting private bank credits is not a problem, but the interests are so high that growers are reluctant to get bank loans to invest. The government acknowledges that there are three main problems with getting access to finance for Croatian farmers: access to loans, high interest rates and high collateral. ${ }^{29}$ However, there are some options for farmers to make use of the EU and state financial instruments. E.g. low interest loans are granted to specific agricultural projects, by a combination of a state credit fund and a commercial bank, where the state takes over some financial risk by giving a guarantee over the loan. Another source of investment are the EU funds that supplement own investment means, however the procedures to get them are considered time demanding and bureaucratic by the interviewed farmers.

In most regions, the governmental development agencies are the main unit for attracting EU funds, national and donation funds for regional level development, where some of the projects are related to agriculture. For example, DUNEA (Dubrovnik-Neretva regional development agency) has been involved in project development and obtaining funds for projects about quality improvement, marketing and crop protection of mandarins.

\footnotetext{
${ }^{28}$ See http://www.savjetodavna.hr/dokumenti/

${ }^{29}$ See https://www.fi-compass.eu/pictures/albums/third-annual-eu-conference-on-eafrd-financial-instruments-foragriculture-and-rural-development-in-2014-2020-paris-10-october-2017/content/mr-kresimir-ivancic-assistant-ministerministry-of-agriculture-croatia/
} 
In the Doing Business reports the World Bank assesses how well do the credit information system and collateral and bankruptcy laws facilitate access to credit in the world. In $2017,{ }^{30}$ the World Bank scored the Croatian economy a 6.0 on the depth of credit information index $(0-8)^{31}$ and a score of 5.0 on the strength of legal rights index $(0-12) .{ }^{32}$ Higher scores indicate more credit information and stronger legal rights for borrowers and lenders.

Globally, Croatia stands at 75 in the ranking of 190 economies on the ease of getting credit (Figure 4.1). It's 'distance to frontier'33 score is 55 (compared to the highest score of 100).

Distance to frontier score 2017

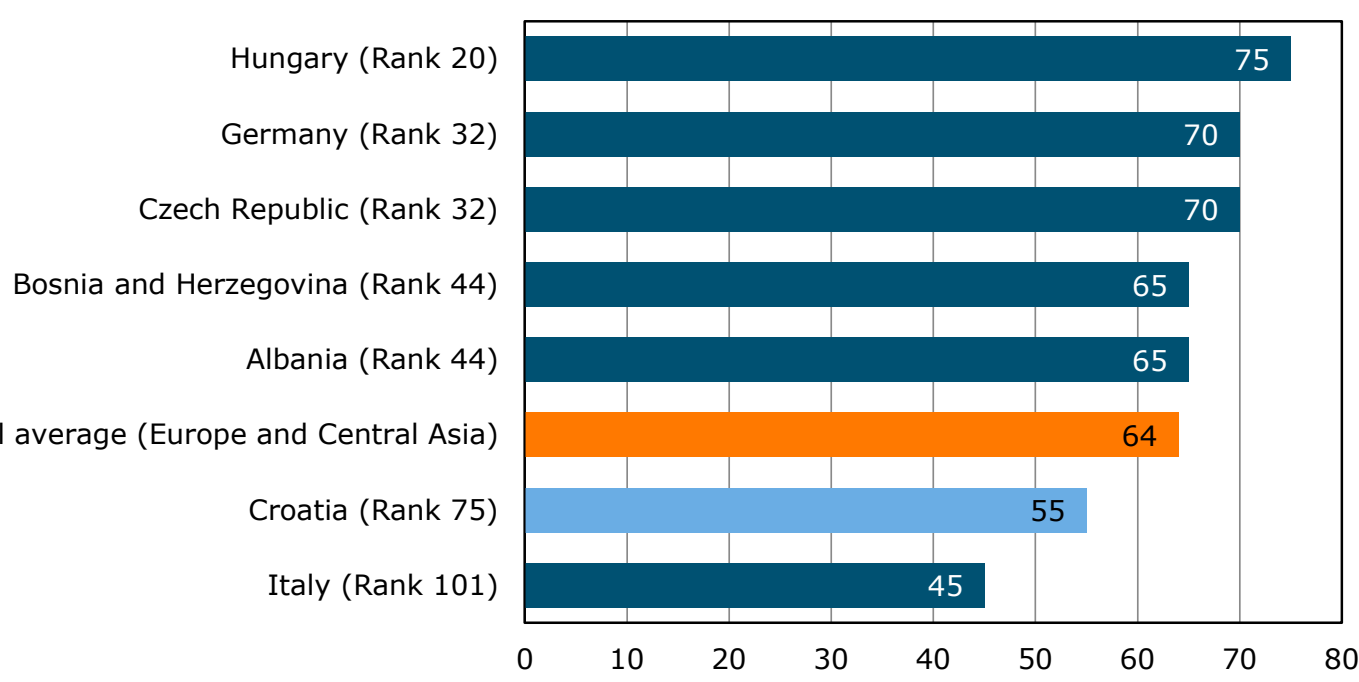

Figure 4.1 The World Bank ranking scores on the ease of getting credit of a number of selected regions in Europe

Source: The World Bank 2017, Ease of Doing Business.

Another issue is the way farmers manage their loans. The interviewed growers also acknowledge that sometimes they experienced lack of knowledge and skills for the most effective use of loans, or they observe the irrational use of resources with their fellow growers. In this perspective, next to increasing the opportunities of accessing credits and loans, improving the understanding of credit and credit management for farmers, and general business and management skills improvement are advised.

\footnotetext{
30 http://www.doingbusiness.org/ /media/WBG/DoingBusiness/Documents/Annual-Reports/English/DB17-Report.pdf

${ }^{31}$ This index measures rules and practices affecting the coverage, scope and accessibility of credit information available through either a public credit registry or a private credit bureau.

32 This index measures the degree to which collateral and bankruptcy laws protect the rights of borrowers and lenders and thus facilitate lending.

${ }^{33}$ The distance to frontier score helps assess the absolute level of regulatory performance over time. It measures the distance of each economy to the 'frontier,' which represents the best performance observed on each of the indicators across all economies in the Doing Business sample. An economy's distance to frontier is reflected on a scale from 0 to 100 , where 0 represents the lowest performance and 100 represents the frontier.
} 


\section{$5 \quad$ International market opportunities}

\section{$5.1 \quad$ Introduction}

For each of the seven selected products, a data analysis was performed to identify which foreign markets are potentially interesting for Croatian produce. The analysis is based on the attractiveness of the import market and the relative position of Croatia on that market. A market is thought to be more interesting if it has a good overall attractiveness and/or if the market position of Croatia is already well established. Generally speaking, if the market attractiveness is low and the current business position of Croatia is low, there is no point in trying to expand business in that market. The methodology of the analysis is shortly explained in the textbox below; See Appendix 3 for further information.

Market attractiveness and business position analysis

For each of the products, first we have determined which countries can be seen as important competitors. This selection is based on the imports of produce in Croatia (competitors on the home market) and imports of produce in the European market (competitors on European market including non-EU countries). Then we have determined the market attractiveness and business position of Croatia in about 260 countries worldwide for the selected products. The indicators used are all derived from international trade statistics (UN Comtrade) for the period 2005-2015.

Market attractiveness:

- SIZE of the import markets in 2013 to 2015 in euro

- GROWTH of the import markets between 2009 to 2011 and 2013 to 2015 in euro

- STABILITY of the import markets between 2005 and 2015

- IMPORT PRICE as the average import markets' price for 2013 to 2015

- CONCENTRATION of the import markets in terms of sum of squared market shares of all exporting countries on the respective import markets (HHI) in the period 2013 to 2015

Business position:

- SIZE of imports from Croatia in 2013-2015 in euro

- MARKET SHARE of Croatia on the respective market in \%, in 2013-2015

- IMPORT PRICE of produce from Croatia in the period 2013-2015

The results from the various indicators are weighted and summed to get an estimate of the attractiveness of the various markets and the position of Croatia on them. After that, the two indicators are combined to see which markets are most interesting: the market windows. These can be markets that are very attractive, but on which Croatia does not already have a very good position, or markets that are somewhat less attractive but that seem to have a preference for Croatian produce judging from Croatia's good business position, or markets which are both attractive as well as on which Croatia has a good position.

For a lot of perishable fresh produce, international trade is regional rather than truly global, meaning that e.g. vegetables in the United States are mostly sourced from nearby producing regions like Mexico, whereas EU trade in fresh produce is mostly intra-EU or between Africa and Europe. Although some markets may be very interesting in terms of volumes, average prices and growth rates, it may not be sensible to export fresh produce from Croatia to faraway markets due to high transportation costs and competition from nearby producers. To avoid that our analysis yields market windows that are not really attractive because trade would not even be feasible (e.g. due to high transportation costs) we include only those countries that already import a certain amount of produce from the benchmark countries or from Croatia. The thresholds are set depending on the type of product (apples and mandarins are traded over longer distances while e.g. cherries are rarely traded over long distances), and the overall size of trade flows. The thresholds for tomatoes, mandarins and apples ( $€ 2 \mathrm{~m}$ threshold each) is set higher than for onions $(€ 1 \mathrm{~m})$, cabbages $(€ 1 \mathrm{~m})$, garlic $(€ 100,000)$ and cherries $(€ 50,000)$.

In this way the analysis tends to include only interesting markets that may actually be attainable. Nevertheless, the results require a qualitative assessment and characteristics of individual market windows should be further analysed before a decision to export is made. For instance, because China and Argentina are among the benchmark countries for garlic, Indonesia and the USA are among the found interesting market windows. In reality these very large but faraway markets are at the moment dominated by China and Argentina as relatively cheap suppliers and may not be feasible for Croatian exporters.

Note that Croatia is at present not a large exporter of fruit and vegetables, which means that average prices, market shares and size of the imports from Croatia are based on a limited number of shipments and may be quite volatile from some of the products. Also, the business position of Croatia is determined relative to other markets that Croatia is exporting to. In the case that Croatia is hardly exporting anything yet, a country to which Croatia is just exporting a few shipments might surface as a country with good business position for Croatia. In this case some qualitative adjustments to the ranks of the market windows are made (e.g. by giving more weight to the scores on market attractiveness than on business position). 


\subsection{International opportunities: from nearby to further away}

The results of the analysis are described in more detail in Appendix 3 and 4. Below we highlight the most important conclusions.

Table 5.1 Summary of market windows, top-5 most attractive markets in general, top-5 best business positions for Croatia, and top-5 market windows

\begin{tabular}{|c|c|c|c|c|}
\hline Product & $\begin{array}{l}\text { Top-5 Market } \\
\text { attractiveness }\end{array}$ & $\begin{array}{l}\text { Top-5 Business } \\
\text { position, a) }\end{array}$ & $\begin{array}{l}\text { Top-5 Market } \\
\text { windows for Croatia }\end{array}$ & Notes \\
\hline Tomatoes & $\begin{array}{l}\text { Germany } \\
\text { Russian Federation } \\
\text { France } \\
\text { United Kingdom } \\
\text { Belarus }\end{array}$ & $\begin{array}{l}\text { Slovenia } \\
\text { Bosnia Herzegovina } \\
\text { Netherlands } \\
\text { Austria } \\
\text { Romania }\end{array}$ & $\begin{array}{l}\text { Slovenia } \\
\text { Bosnia Herzegovina } \\
\text { Germany } \\
\text { Netherlands } \\
\text { Austria }\end{array}$ & $\begin{array}{l}\text { Exports are currently limited } \\
\text { and mostly to Slovenia, but } \\
\text { growing. Russian market is } \\
\text { closed for EU but is an } \\
\text { interesting market otherwise. }\end{array}$ \\
\hline Cabbages & $\begin{array}{l}\text { Germany } \\
\text { Netherlands } \\
\text { Kuwait } \\
\text { France } \\
\text { Norway }\end{array}$ & $\begin{array}{l}\text { Slovenia } \\
\text { Lithuania } \\
\text { Italy }\end{array}$ & $\begin{array}{l}\text { Slovenia } \\
\text { Italy } \\
\text { Lithuania } \\
\text { Germany } \\
\text { Netherlands }\end{array}$ & $\begin{array}{l}\text { Croatia is hardly exporting } \\
\text { cabbages, except to Slovenia } \\
\text { ( } € 240 \mathrm{k} \text { in } 2015) \text {, Bosnia and } \\
\text { Herzegovina ( } € 80 \mathrm{k} \text { ), Lithuania } \\
\text { ( } € 30 \mathrm{k} \text { ). The Bosnian import } \\
\text { market is however too small } \\
\text { to be included as market } \\
\text { window (<€1m threshold). }\end{array}$ \\
\hline Onions & $\begin{array}{l}\text { USA } \\
\text { United Kingdom } \\
\text { United Arab Emirates } \\
\text { Germany } \\
\text { Netherlands }\end{array}$ & $\begin{array}{l}\text { Slovenia } \\
\text { Bosnia Herzegovina } \\
\text { Hungary } \\
\text { Serbia } \\
\text { Germany }\end{array}$ & $\begin{array}{l}\text { Slovenia } \\
\text { Bosnia Herzegovina } \\
\text { Germany } \\
\text { Hungary } \\
\text { Serbia }\end{array}$ & $\begin{array}{l}\text { Almost no exports from } \\
\text { Croatia. USA dominated by } \\
\text { Mexico. Onions are also } \\
\text { exported to further away } \\
\text { markets in Africa (Sierra } \\
\text { Leone) and the Middle East. }\end{array}$ \\
\hline Garlic & $\begin{array}{l}\text { Luxembourg } \\
\text { Finland } \\
\text { Sweden } \\
\text { Germany } \\
\text { Switzerland }\end{array}$ & Slovenia & $\begin{array}{l}\text { Slovenia } \\
\text { Luxembourg } \\
\text { Finland } \\
\text { Sweden } \\
\text { Germany } \\
\text { Switzerland }\end{array}$ & $\begin{array}{l}\text { USA and Indonesia (not } \\
\text { feasible) and Bulgaria (not } \\
\text { most attractive) excluded as } \\
\text { potential market windows (see } \\
\text { Appendix 4). }\end{array}$ \\
\hline Mandarins & $\begin{array}{l}\text { Russian Federation } \\
\text { United Kingdom } \\
\text { France } \\
\text { Germany } \\
\text { Netherlands }\end{array}$ & $\begin{array}{l}\text { Serbia } \\
\text { Bulgaria } \\
\text { Bosnia Herzegovina } \\
\text { Slovenia } \\
\text { Czech Rep. }\end{array}$ & $\begin{array}{l}\text { Serbia } \\
\text { Russian Federation } \\
\text { Bulgaria } \\
\text { Bosnia Herzegovina } \\
\text { Slovenia }\end{array}$ & $\begin{array}{l}\text { USA excluded as potential } \\
\text { market. Russian market is } \\
\text { closed for EU but is an } \\
\text { interesting market otherwise. }\end{array}$ \\
\hline Sour cherries & $\begin{array}{l}\text { Germany } \\
\text { Luxembourg } \\
\text { United Kingdom } \\
\text { Netherlands } \\
\text { France }\end{array}$ & $\begin{array}{l}\text { Bosnia Herzegovina } \\
\text { Serbia } \\
\text { Germany }\end{array}$ & $\begin{array}{l}\text { Bosnia Herzegovina } \\
\text { Serbia } \\
\text { Germany } \\
\text { Luxembourg } \\
\text { United Kingdom }\end{array}$ & \\
\hline
\end{tabular}

a) Markets included only to which Croatia exported more than $€ 10$ thousand of produce to on average between 2013-2015. 
- For most of the studied products, except apples, Slovenia, Bosnia and Herzegovina, and Serbia are among the top-ranking trade partners in terms of business position for Croatian exports. These markets are important to Croatia and the position that Croatia has, should be consolidated. And hence they are included as market windows. However, the analysis shows that these markets are generally not the most attractive in terms of size, growth and average prices paid.

- In general there is not much overlap between the markets that are found to be most attractive and the markets on which Croatia has a good position. Especially in terms of prices paid it seems that Croatia is focussing on markets that generally pay lower prices. On the other hand, more attractive markets like Germany, France and Russia (pre-import ban) are mostly located further away and it requires good export logistics to reach these markets at competitive prices.

- With the exception of cabbages and apples, prices that Croatian exports are getting in foreign markets are generally lower than the average import prices in those markets. Even the highly praised satsuma mandarins are fetching lower than average prices in Serbia, Slovenia and Bosnia and Herzegovina, compared to the annual average import price of mandarins in these markets. This indicates either lower average quality or the fact that Croatian produce is available at times that prices are lower due to high seasonal supply from other competing countries. In reality both may be real and should be addressed.

- For tomatoes, exports from Croatia are very low. Exports are almost all going to Slovenia. In terms of market windows, Germany, France and the United Kingdom are large, stable and growing markets. Especially in Germany and the United Kingdom import prices of tomatoes have been relatively high. The same applies to the Netherlands, to which Croatia has already exported some small volumes of tomatoes in the past.

- For cabbages, exports from Croatia are even smaller: current exports from Croatia go almost exclusively to Slovenia. Germany is the largest market for white cabbages in the EU, and the Netherlands is also importing cabbages (both for fresh consumption as well as for processing into sauerkraut). In the short run Croatian exporters can further develop nearby markets on which they already have a position, and start exporting to Germany. Italy and Austria (Austria is outside top- 5 because exports from Croatia are below $€ 10$ thousand threshold to calculate business position) are also found to be interesting for cabbage exports. In the Middle East, Kuwait is growing fast as an importer of cabbage.

- Onions from Croatia are also not very much exported. For onions, the most attractive market is the USA. Exports to the USA are however dominated by Mexico. Just a few exporters from the Netherlands and Spain export smaller volumes of onions the USA and this market seems not very interesting for Croatian exporters at the moment. Therefore, the most interesting market windows for onions may be in nearby markets in Slovenia, Bosnia and Herzegovina, Italy, Greece and Germany.

- For garlic, Indonesia and the USA turn up attractive markets (see Appendix 4) because of their size and growth, but also because benchmark country China is exporting to it. These markets are however not very interesting for Croatia because of their distance and dominance by China. At the moment garlic exports from Croatia are very limited and mostly to Slovenia. For the special garlic from Croatia there is potential in high-end export markets such as Luxembourg, Finland, Sweden, and Switzerland, and nearby markets like Slovenia and Serbia. Croatia is already exporting some small volumes of garlic to the Netherlands.

- For apples, Croatian exports are already considerably larger than for the previous products, although export flows to most countries do not exceed $€ 1 \mathrm{~m}$ per year. Egypt was the number one market in terms of market attractiveness and also ranked among the top markets in terms of business position. Although exports from Croatia to Egypt are still volatile, this indicates the potential of exporting apples to further away markets. The United Kingdom, Germany and the United Arab Emirates were also found to be attractive markets in terms of size, growth, and prices. In the top-20 (see Appendix 4) are a number of countries from the Middle East turn up as interesting market windows.

- Although mandarins are among the products for which Croatia is a net-exporter, they are mostly being exported to relatively nearby countries Serbia, Slovenia, and Bosnia and Herzegovina. These markets are offering opportunities for Croatian exporters as consumers have an apparent and revealed preference for Croatian mandarins. However, some further away markets may be more attractive in terms of market size, growth and prices paid. The United Kingdom, France and Germany offer higher prices for quality mandarins. In the period 2013-2105, however, prices paid 
for Croatian exports to these markets were lower than average import prices from all countries. This is partly caused by high seasonal supply from European competitors in the period that Croatia is on the market, and the fact that prices are generally higher when they are imported from further away. The USA market is also found to be an interesting market, but is generally thought to be too far away for the moment.

- Although Croatia is a net-exporter of sour cherries in 2015 and 2016, total exports are just about two thousand tonnes, most of which goes to Bosnia and Herzegovina, Germany and Serbia in the period 2013-2015. Exports are volatile but seem to be increasing in recent years. Just a few years ago Croatia was a net-importer of sour cherries. Therefore, it is difficult to judge Croatia's business position on foreign markets. New data for 2016 (not included in the analysis) shows that Croatia exported sour cherries to Austria, the Czech Republic and Hungary as well. Germany, Luxembourg, the United Kingdom and the Netherlands are also found to be interesting market windows for sour cherries.

In general it seems that the most interesting markets for Croatian fruit and vegetables are in EU countries Germany, France, the United Kingdom, and Scandinavia, as well as in central and Eastern European countries and the Middle-East. The Russian import ban is especially bad news for exporters of apples, mandarins and tomatoes. Once the ban is lifted in the future, Croatian exporters may find interesting business opportunities in Russia as well. 


\section{$6 \quad$ Opportunities and examples}

\subsection{Introduction}

The study focusses on opportunities to improve the competitiveness of the Croatian fruit and vegetable sector. In this chapter the opportunities and some inspiring examples are presented.

\subsection{Opportunities and examples}

\section{New opportunity crops}

In this study we focused on seven examples of important fruit and vegetable crops in Croatia: tomatoes, cabbages, onions, garlic, apples, mandarins and sour cherries. Next to these crops there are many smaller, valuable fruit and vegetable crops.

Opportunities can be found in new, in Croatia less known and grown crops like table grapes and blue berries. Looking at demand and supply, these products are especially interesting because harvest time and supply is during the high season of tourists. These new crops are also interesting for export, for example to Northwest European countries. A disadvantage of grapes and berries is the labour intensity during harvest time: all products have to be picked by hand and scarcity of labour is a problem during that period. On some production sites self-picking by tourist for own consumption can be organised within agro-tourism concepts, but at this moment this is not considered as a general solution for the labour scarcity problem.

Another opportunity crop are plums. Plum production decreased in Croatia. Nowadays, plums are largely imported for the Croatian market. During the Forum on Challenges in the Development of the Croatian Fruit and Vegetable Sector in Zagreb on November $8^{\text {th }} 2017$ the representatives of the processing industry mentioned the need of locally grown plums. In general, the Croatian processing industry is looking for business relations with growers of different types of fruits like apples, pears, etc.

Example Mandarin opportunities

- Satsumas are an early mandarin variety, only available during a few months. An opportunity is to extend the season (e.g. late varieties, storage) to create a longer period of market supply.

- Croatian mandarin growers already have knowledge of citrus growing, and climatic conditions in South Adriatic are perfect for mandarins.

- Introduce mandarins to tourists who visit the Adriatic region for holidays. Distribute fresh satsumas (e.g. hand out samples in Dubrovnik tourist area) so tourists become acquainted with Croatian fruits.

- Export satsumas and other mandarin varieties to Western Europe (e.g. Germany, UK) and also Russia after removal of the ban. Before exporting it is important to examine if European consumers prefer the taste of satsumas.

- Other opportunities are processing of mandarins: juice, jams, distillation.

- In spite of good yields and farm results, improving farm management, entrepreneurship and cooperation should receive attention continuously.

- A lot of mandarin growers are small, parttime growers. For them mandarin growing is just additional income. At worst they pay less attention to their mandarins and realise non-optimal results. A specific action plan for this group of small, parttime growers may be helpful for them to strenghten professionalism.

\section{Improving knowledge and experience}

To become a successful fruit and vegetable grower it is useful to see and get knowledge of the sector in other regions and foreign countries. An attractive and efficient way to exchange knowledge and 
improve experience is to organise exchange programmes with foreign (EU) countries which are frontrunning in growing, trading and processing of fruit and vegetables. Visiting these countries for a longer period (months) and do practical work in fruit and vegetable business is the best way to see and learn elsewhere (inspiration on the job). To support this, it is advised to set up an exchange programme for students and young growers, but also for officials and other stakeholders working in the fruit and vegetable chain. Some suggestions to set up exchange programmes:

- Open a national desk for exchange programmes where interested people can find different existing exchange programmes and get support to set up such programs (central point, coordination and website).

- Organise and support excursions and study tours to foreign countries (good example: the young Croatian farmers who visited Italy in 2017, supported by ERBD).

- Organise or support visits to (international) fairs like Fruit Logistica, Biofach or Potato Europe.

- Internationally-operating private companies have own management development programmes. Their employees are working on different international locations for a certain period.

- Make exchange as a part of university and college programme. In this perspective, it is helpful to set up so called country tables: exchange programmes between Croatian education institutions and institutions elsewhere. Students from elsewhere visit Croatia while Croatian students visit the foreign country.

\section{Improving entrepreneurship}

Several developments are forcing farmers, including fruit and vegetables growers, to reconsider their involvement in agricultural (fruit and vegetable) production, with especial attention to their entrepreneurial behaviour. Today, growers need insight in their entrepreneurial skills and competences, and in the way these competences can be improved. The availability of farming business focused trainings is important. Examples of such farm business trainings can be found elsewhere. E.g. Dutch researchers developed programmes to support farmers improving entrepreneurship. Themes discussed during courses with participating farmers are for example: leadership, sustainable entrepreneurship, innovation, farm succession, business models, and changing market environment.

\section{Entrepreneurship courses}

Two examples of projects focussing on improving entrepreneurship in the Netherlands: 1 . Fruit masters and 2. Successor perspective.

1. Fruit Masters is an initiative to foster new business initiatives. A course was organised for members.

2. Successor perspective is a course organised for young successors who are preparing farm takeover.

Courses are set up in collaboration with research (Wageningen University \& Research), a bank (Rabobank) and branch organisations (Dutch fruit growers organisation NFO and Dutch young farmers organisation NAJK). Entrepreneurship courses focus on:

- Determine long term strategy

- Work on (future) business model

- New knowledge and innovation

- Learn from other participants during group sessions

\section{Young cabbage farmer from Dubrovnik region}

During the mission we met a young successful farmer. He was a real entrepreneur, introduced as mandarin grower, but has also a significant share of cabbage growing on his farm (white cabbage).

- Businessman; employer of 50 employees of which one agronomist. Farm size 100 ha, yearly 80 ha cabbage.

- Visits foreign fairs and seed supplier yearly.

- This farmer indicated the good potential for winter cabbage. He made the most of one's opportunities that the South Croatian season differs from France and the Netherlands.

- Selling products: this young entrepreneur knows it is more easy to sell if you are bigger and have more product (volume). He sells product directly to supermarket (Lidl, Konzum, AgroFructus).

- He intends to export cabbage to EU next year and Poland in the near future: he has already contacts to realise this (networker). 


\section{Osatina Gruppa}

Very modern Croatian farmer company, business model based on circular economy. Vegetable production is part of the total concept.

- Tomato production in modern greenhouses (e.g. cherry and cocktail tomatoes).

- Circular economy: smart mix of horticulture, arable farming, livestock and biobased (biogas, minimal waste).

- The company focusses on export and large super market chains

http://www.osatina.hr/en/

\section{Strengthen cooperation}

During the field visits interviewees indicated lack of cooperation as a problem in the Croatian fruit and vegetable sector. Especially small, older growers avoid to cooperate because of bad experiences in the past and lack of trust. Nevertheless set up of producers cooperatives should be supported. Some advantages of cooperatives are:

- Efficient collecting of farm products including collective transport, product preparation (sorting washing, packing) and storage

- Less costly access to finance and technology

- Less costly technical and managerial assistance

- Easier access to national and international markets

- Less costly marketing of (branded) products

A basic rule for successful cooperation: trust and transparency needed of all members of a cooperative.

\section{The Slavonian Apple Cluster}

This is an example of a group arable farmers who were afraid the new Common Agricultural Policy (lower subsidies) would threaten the future of their farm business. They looked for an alternative and successfully changed to apple growing and cooperation. These farmers did not have any experience in apple production before.

- When starting (conversion) they intensively focussed on supply of knowledge and went to the Netherlands and Austria to learn from apple growers and their organisations over there. To improve experience in apple growing, storage and marketing they also involved people from Croatian institutions (e.g. a university). They started and cooperated to realise a cluster they believed in.

- Due to cluster cooperation they have large quantities apples available. $80 \%$ of the cluster production is classified as first and second class apples.

- Risk management at farm level: beside apples they also produce other fruits and nuts.

- Export opportunities depend on supply, varieties and period.

- Frost years and debtors postpone investments (lack of cash, support on investment).

Association of garlic producers of Slavonia and Baranja 'Slavonski česnjak'/'Slavonian garlic'

- Young association of garlic and bean producers; about 300 members, small producers, family farms.

- The association supports the growers by: education, advisory, marketing, branding ( 2 domestic brands) promotion on local markets and fairs, seed, packaging and meetings.

- They grow a local garlic variety. This variety has a special taste which Croatian consumers prefer, especially when they prepare certain local dishes.

- Selling area of Slavonian garlic: local Croatian markets and inland retailers. Due to the small production this special garlic is not exported.

- Selling is centralised and leaded by the association, product is not sold individually.

- The association has no intention to export Slavonian garlic in the short term. Export needs volume and further professionalisation is necessary.

\section{Domestic market demand (tourism, organic, convenience)}

There are promising opportunities which will increase domestic market demand:

- Preference for local product: Croatian consumers prefer to buy fresh Croatian fruit and vegetable product; 
- The number of tourists visiting Croatia increases yearly. These tourists need to eat and prefer fresh and healthy dishes and drinks like salads or smoothies during warm holidays;

- The demand for organic product is rather small in Croatia compared to other European countries, but it has been increasing fast in the latest years. It is expected that demand for organic will continue to increase in future because the number of people who are aware of this market segment and have a positive association with organic ('care about environment', 'safe food', 'more delicious') will increase. Nowadays in Croatia only a certain consumer segment buys organic (urban, well-off financially, giving the best, e.g. organic for their children). For the future, a larger consumer segment will buy and eat organic, as the trend is expected to be similar to other countries in the North West of the EU;

- Western European supermarket chains have experienced growth in fresh convenience fruits and vegetables product sales (cooled product). It is expected Croatia will follow this trend in the near future. The expanding touristic sector and the upcoming of food service providers in Croatia will stimulate supply of and demand for prepared salads and fruits.

\section{Example successful cooperation Nautilus Organic}

- Nautilus is a Dutch cooperative founded in 1987. All members are $100 \%$ organic growers who intend to combine forces of sales.

- Nautilus supplies a very comprehensive range of organic fruit and vegetables, from apples to tomatoes, and from peppers to cabbages.

- The Nautilus cooperation takes care of the sales for members, actively plans demand and supply during season, takes administrative work out off growers hands and is in contact with many domestic and foreign customers.

- Customers are supermarkets, wholesalers, health food shops, catering and processing industries.

- Nautilus trades with more than 250 active purchasers: $25 \%$ of the products are sold in the Netherlands, while the remaining $75 \%$ are distributed to places such as Germany, Scandinavia, the UK, Belgium, France, Italy and the USA.

- There is much interest in the 'delivering directly of yard'

https://www. nautilusorganic.nl/

\section{Vertical chain cooperation}

Growers can seek for opportunities in cooperation with their buyers. Joint product development, value adding to consumers, and joint production planning, promotion and storage can increase benefits to all involved actors.

Example of product development: KANZI \& II

- Kanzi ${ }^{\circledR}$ is an apple of quality, exclusively on sale by Fruitmasters (Dutch cooperation of fruit growers).

- Kanzi ${ }^{\circledR}$ is a club breed. Club breeds are placed under the brand name in a tight club concept and may only be grown and sold by members of the club. KANZI $\AA$ is one of the most successful examples.

- The part of the harvest of KANZI $®$ which does not meet the strict quality requirements, is sold under a different name or immediately processed.

- Unlike the old free breeds like Elstar, the consumer on the shop floor is much less surprised with apples that have the same brand name but differ in quality considerably.

https://www.kanziapple.com/en/

\section{Demand for GLOBALG.A.P certification}

GLOBALGAP is the minimum level of food quality and safety certification today retail organisations ask for. The demand for GLOBALG.A.P certification is expected to increase. Starting from 2018, GLOBALG.A.P or alike is required by all large supermarkets in Croatia. Most successful actors in the Croatian fruit and vegetable sector know and already act on GLOBALGAP. This is also a basic condition to be successful on the export market. It is a challenge for the Croatian fruit and vegetable sector to fulfil this market requirement, especially for smaller farms. It is more costly for smaller farms to implement such schemes. 


\section{Investment in cold storage and agro logistics}

Interviewees note a lack of modern cold storage capacity in Croatia at farm level (e.g. in the apple sector). Extension and modernisation of cold storage capacity will improve the opportunities to extend the storage season, to supply home and foreign markets for a longer period, to preserve product quality during the season and to reduce waste. Especially growers who have cash problems as result of incidental frost damage are less able to invest. A system for temporary support for these growers can be considered (e.g. guarantees on bank loans). To improve export opportunities modern logistics facilities like airports, harbours, hubs and logistic (export) services are essential.

\section{Export opportunities on the EU market and beyond}

For most fruit and vegetables Croatia is not self-supporting. Statistical figures show that production of a number of crops increases and self-sufficiency is within reach, particularly during the season (seasonality). Increasing product supply also means that export opportunities come closer. European markets like Austria, Germany and Poland are within reach but also the neighbouring markets in Slovenia and Bosnia-Herzegovina, Romania, Czech Republic and Slovakia. The MABA-analyses in this report reveal the countries with good export opportunities for Croatian fruit and vegetables.

Example innovation \& cooperation for foreign markets: Tasty Tom (Netherlands)

- The export of Dutch tomatoes to Germany crashed in 1992: German consumers stopped buying Dutch tomatoes because they were tasteless ('Wasserbombe').

- The tomato market crisis was an incentive for cooperation between six growers and a seed supplier. They started an association and developed a new tasty tomato variety (1995).

- Within the joint venture they protected variety name, brand and concept $@ \circledR$.

- The growers association successfully introduced their own brand Tasty Tom: tasteful tomatoes in eyecatching packaging (niche).

- This initiative inspired others for further diversification of the fresh tomatoes market e.g. cherry tomato, snack tomato, vine tomato, different colours and shapes.

- All initiatives resulted in a successful comeback of the export of tasteful tomatoes to Germany.

http://www.tastytom.nl/

\section{EU instruments / grants for fruit and vegetable producers}

The EU actively supports the fruit and vegetable sector though its market-management scheme which has four broad goals:

1. a more competitive and market-oriented sector

2. fewer crisis-related fluctuations in producers' income

3. greater consumption of fruit and vegetables in the EU

4. increased use of eco-friendly cultivation and production techniques.

The EU fruit and vegetable regime supports operational programmes implemented by recognised producer organisations (POs), by making a funding contribution to the programmes' operational funds. The programme supports to strengthen producers' position in the market. The national authorities must set up a national strategy for sustainable operational programmes, to define which measures are eligible for support. POs' operational programmes must be approved by the relevant national authorities.

Example Public - Private Cooperation

- The Dutch province Zuid-Holland participates in a project of enterprise Koppert Cress for storage of heat in the subsoil.

- The aim of Zuid Holland is to reduce $\mathrm{CO}_{2}$ emissions by about $50 \%$.

- The partnership will be undertaken to complete the two-year pilot at Koppert Cress in the next three years with the help of an innovation subsidy from the Ministry of Economic Affairs.

- To realise a climate-friendly province, $\mathrm{CO}_{2}$ reduction is needed. The greenhouse vegetable sector can make a significant contribution by storing high temperature water in the subsoil. 


\section{$7 \quad$ Conclusions and recommendations}

\subsection{Main conclusions}

Croatia has an attractive consumer market for fruit and vegetables.

Fruit and vegetables are relatively popular in Croatia, where the daily consumption of fruit and vegetables is above the EU average. While experiencing relatively fast economic growth in their country, Croatian consumers increasingly demand value added products of high quality, including fruit and vegetables. Also fast growing tourism has created an interesting market for food, both in terms of growing consumption during the tourism season and as a way to promote Croatia and Croatian products abroad.

Supermarkets have become the most important sales channel of fresh fruit and vegetables. Supermarkets require safe products and prefer guaranteed supply of high quality products at lower prices. Supermarkets buy fresh fruit and vegetables from both domestic and foreign suppliers. In addition, Croatia has a developed food processing industry, including fruit and vegetables processing. A number of large food processing companies in Croatia have strong domestic and export brands. The Croatian processing industry prefers locally grown produce of good quality. A part of these products is produced by smaller growers on long term contracts with the industry.

\section{Intensive competition from foreign suppliers on local market}

Despite of the seemingly favourable demand conditions, Croatia is below self-sufficient in production of most fruits and vegetables. In addition, Croatian growers of products for the fresh markets experience competition from foreign suppliers in terms of price, quality and continuity of supply. Croatia has a large number of small unspecialised farms, often using inefficient production methods and lacking access to the European markets. The Croatian fruit and vegetable farming sector will benefit from increasing its competitiveness and further developing its position on domestic markets. In the short term, Croatian growers need to focus on improving yields, efficiency, product quality and on ensuring a certain supply volume to their buyers. This in order to be able to keep serving the domestic market and in order to face up to increasing competition from foreign suppliers. There is room for further development of Croatian growers' position in the supermarket and tourism market via cooperation with other supply chain partners.

\section{Good firm performance essential}

Croatian and foreign examples show that good firm performance is often related to applying smart and efficient production, storage, and marketing techniques (e.g. using ICT and precision farming on their (small) farms), good risk-management, and having a successful cooperation with other growers (e.g. in sharing production and marketing costs, product volume bundling and collective bargaining) and or other supply chain partners (e.g. in product development, GLOBALG.A.P).

\section{First the home market than the export}

A good competitive position of firms on domestic markets is a necessary pre-condition in exploring international markets and expanding the exports. In the longer term the Croatian fruit and vegetable sector will benefit from development of buyers network, product marketing, EU quality labels (Protected Designation of Origin (PDO) and Protected Geographical Indication (PGI)) and export logistics improvement, in order to develop export markets.

\section{Learn from the successes in export}

Currently, only two of the seven products studied in this report are exported fresh on a relatively large scale, mandarins and apples, of which the latest only recently. At the same time, there are growers in other fresh fruit and vegetables that are already relatively successful on foreign markets. These best practices are at least distinguished by the ability to (jointly) organise highly efficient farming and deliver high quality products of guaranteed volume. Moreover, other strengths like product and brand 
development, extending the growing season to benefit from periods of lower supply from other countries, investments in good business relations abroad, and the ability to deliver added value to foreign buyers were mentioned as important keys for success as well. Some successful exporting growers use their domestic network of buyers that operate on foreign market (e.g. foreign supermarket chains in Croatia) to get access.

\subsection{Recommendations}

Our recommendations are based on the analysis of the various supply chains and are directed towards the various stakeholders. The recommendations are grouped into four main themes: be competitive, improve professionalism, explore markets, and remove barriers.

\section{Be competitive}

The first recommendation concerns the improving of horticultural production methods and yields. Average yields in Croatia in the studied products, have been found to be below that of most competitors (with exception of mandarins and garlic). The private sector can greatly increase average yields in almost all products by e.g. applying better cultivation methods (e.g. plastic tunnel usage, greenhouses, better irrigation systems, IT use), improving farm management and using better quality seeds and planting material. Cultivation methods may be increased by organising 'peer groups' and extension services. Second, besides increasing average yields, the Croatian horticultural sector tends to face significant variation in production due to weather conditions such as hail and frost, and pests. Improving the resilience of the sector against weather and pests and addressing climate change challenges is a major opportunity for improvement. We propose to look for practical measures like the use of best qualified seeds, integrated crop management, irrigation, controlled atmosphere storage. In addition, growing late/early varieties of e.g., mandarins will give growers advantage at the expense of competitors that supply within a regular season (see the early variety advantage of Croatian satsumas).

In the course of our study the lack of sufficient storage capacity for growers and cold chain facilities in general is an often heard complaint. Because growers are generally too small to invest in (cold) storage, produce has to be sold off right after harvest. Storage capacity is generally owned by traders. That means that growers have very little influence on pricing. Over-investment in storage capacity will not be productive either. Nevertheless, assessing and upgrading cold chain facilities and improvement of access to storage for growers is recommended. Joint investment in storage capacity (buying or hiring) or joint organisation of existing segmented storage capacity by (groups of) growers can extend the supply season for growers and improve their bargaining position.

The cooperation between farmers in Croatia is relatively low. The market share of agricultural cooperatives is among the lowest in the EU. At the same time, cooperation between farmers has a potential to improve farmers' market position giving advantages in collective bargaining and/or lowering production or marketing costs per farmer. Some notable examples of cooperation between growers in Croatia have led to successes in recent years. The yields of garlic and apples have increased dramatically, much of which has to do with the emergence of active grower associations. Therefore, a further development of farmer associations and partnerships is recommended. In addition, EU recognised producer organisations get access to CMO support measures for setting-up the organisation and management, and access to other instruments including subsidies for operational programmes and investments.

For farmers trust between and transparency toward the members of a cooperative is a necessary precondition for its proper functioning. It is advised to farmers together with the academia and public services to explore on what conditions trust and transparency within farmer partnerships could be improved within the Croatian context.

Growers can also benefit from cooperation with other supply chain actors, including their buyers. When focusing on the national and international wholesalers and retailers, growers need to keep in mind that supermarkets demand large quantities of uniform product quality. To become a regular supplier to the large retail chains, timely delivery and cooperation on special promotion activities, as 
well as flexibility with regard to seasonal or growing demand are crucial. Value adding on farm level (e.g. packing, ready-to-eat products) is a way to get benefits, such as higher returns that come with the investment, the opportunity to open new markets and to extend the producer's marketing season as well as the ability to create new recognition for the farm. ${ }^{34}$

Being able to better serve domestic markets and to enter foreign consumer markets becomes a key point of attention for the Croatian growers. Fruit and vegetable products need to fulfil certain quality and safety standards to be sold on the Croatian and foreign consumer markets. Most supermarkets in Croatia and abroad have their own standards (codes of practices) regarding quality and safety, which often are stricter than legislation. For example, large retail chains in Croatia require GLOBALG.A.P. or equivalent systems from their suppliers. On the EU markets food safety standards are even more strict already. For all Croatian chain partners, including public services, it is recommendable to improve awareness and support for quality assurance systems like GLOBALG.A.P.

\section{Explore markets}

Another recommendation concerns niche and foreign market exploration. There are opportunities on the domestic market for niche products. For example, markets for organic products, other distinctively sustainable, healthy and premium products, specialties for tourism, restaurants and other food service, are growing in Croatia. In particular smaller producers can be successful on niche markets in creating value and establishing a profitable business. It is advisable for Croatian producers to take advantage of such high-demand product niches.

Improving existing regional supply chains of domestic products and designing of new supply chains for tourism is necessary for improving the quality and availability of products for tourism. Although local supply chains may be short, they are not necessarily less complicated than global supply chains. Organising the efficient and safe supply chain processes that are necessary to supply to quality restaurants and hotels requires professionalism throughout the chain, and cannot easily be organised by farmers alone. The involvement of other actors in the supply chain and (government) stakeholders is crucial as small farmers/boutique hotels cannot set up a chain alone. E.g., one of the important issues that has to be addressed is food safety control.

Marketing is a good way to enhance desirability of a product. On one hand, consumers expect to pay lower prices for unbranded products or for those with low brand equities. On other hand, they pay premiums for their treasured or socially valued brands (see Kotler and Gertner, 2002). Branding can be used as an instrument to attract certain groups of Croatian consumers. It is recommended to growers, wholesalers and other distributors to work together on developing a good branding strategy. Using the popularity of Croatia as a tourism destination and country brand and creating attention for Croatian products among foreign tourists can be a way to create demand on foreign markets. However, using a country as a brand with integrated marketing communication in terms of advertising, promotion material, packaging and brand management both domestically and abroad is not risk-free and requires cooperation of different value chain actors.35 On the EU level, quality labels like PDO and PGI are widely recognised as giving a guarantee of genuine products with certain qualities to buyers. Producers benefit from having availability of EU promotion funds for PDO and PGI products and from being able to sell these products with a certain price premium36. However, getting advantages from EU quality labels requires proper (joint) label management and market access strategy.

When it comes to export promotion, a proactive attitude of growers and other supply chain actors is necessary. Growers and/or their wholesaling partners should be aware of local taste preferences, quality and market structure in other countries. In some cases, a thorough market research is needed to find out whether or not your product could fit in other markets. Trade fairs like Fruit Logistica in Berlin are valuable for developing contacts between growers or growers' representatives and importers. Public

\footnotetext{
${ }^{34}$ See Mattewson (2007). Available on http://smallfarms.oregonstate.edu/sfn/su07valueadded

${ }^{35}$ An example of a successful country and product combination branding is Colombian coffee (Café de Colombia). The National Federation of Coffee Growers of Colombia is responsible for the campaigns. The organisation promotes the production and exports of Colombian coffee and represents more than 500,000 producers, most of whom are small family owned farms.

${ }^{36}$ See http://europa.eu/rapid/press-release_MEMO-13-163_en.htm
} 
services can facilitate export promotion by re-activating the role of an export promotion bureau in providing assistance in developing exporting activities, e.g. establishing international business relationships, market research, training and consulting.

\section{Improve professionalism}

Farming is a business where grower-entrepreneurs face risks, work under pressure and are immediately accountable for the outcomes of their decisions. Fast developments in the competitiveness position on domestic and foreign markets require a certain level adaptive ability of Croatian growers. In Croatia, there are large numbers of (part-time) growers that lack farming and/or business background, or have their main employment elsewhere and less focus on farming. At the same time, entrepreneurial qualities of growers are important for finding a balance i.e., controlling its own position in an increasingly competitive landscape. Therefore, a further enhancement of entrepreneurship, professionalism and market awareness of growers in Croatia is recommendable. Public services can take a role in facilitating growers in defining their farm strategy and facilitate attractiveness and use of the extension service.

Agricultural technology education is part of the Croatian agricultural education system. Basic farming skills are a requirement on a farm, but also innovation and technological development should be taken into account within the education programmes. It is necessary that the Croatian fruit and vegetable sector, educational institutions and public services cooperate and coordinate shaping of agricultural programmes to adjust their quality to the needs of the sector. Courses on issues that need immediate improvement in the fruit and vegetable farming sector, e.g. post-harvest treatment and technology, good agricultural practises (GLOBALG.A.P) or (international) masterclasses on new farming technology should be in the curricula for vocational education and for BSc and MSc students.

Sharing of expertise with international business partners and educational and public institutions, and learning from international best practices are recommended. Exchange programmes with foreign experts for growers, students and public services employees will contribute to professional development and strengthen international networks. Dealing with policy or business issues will be much easier when Croatian stakeholders do not have to reinvent the wheel, but ask colleagues in other countries that have experienced same issues before.

\section{Remove barriers}

In the course of the study various value chain stakeholders in Croatia mentioned that working in agriculture is often related with less paid dirty work by outsiders. This, often unjustified, negative image influences the ability to attract workers, agricultural start-up businesses and ensure business take-over in Croatia. It is recommendable to the Croatian farming sector in cooperation with public institutions to develop a strategy for enhancement the image of agriculture business and improve the attractiveness of farm work by e.g. showing the improvements in the level of mechanisation and ICT, diversity of task, payments and training.

There are examples of innovative entrepreneurship and from the interviews it seems that there is room for genuine innovation initiatives. Public institutions are recommended to further remove barriers and focus on the improvement on the general business climate, i.e. shaping a stimulating environment and removing of the administrative burdens for starting a business, registering property and getting construction permits. In this perspective, speeding up land reform (arable land consolidation and land market efficiency) will greatly contribute to the improvement of conditions of setting up a farming business.

Many examples - like the Klaster Slavonska Jabuka, and the Garlic Association - show how cooperation between the growers and research institutions can have a positive effect on farm management and yields. In the past there has been a more directive form of cooperation between large processors and traders (most notably Agrokor) and growers. With the current changes in the position of Agrokor in Croatian fruit and vegetable chain management, it is urgent to develop a strategy on how to shape the innovation system of Croatian farming. A vision about how the future of the Croatian fruit and vegetables sector will look like in the future will help to create focus and clearness. For developing a vision, a constructive dialogue of policy makers with farmer organisations and close interaction between the farming sector, public sector, research, education and other stakeholders is needed. 


\section{References and websites}

\section{References}

Bijman, J., C. Iliopoulos, K.J. Poppe, C. Gijselinckx, K. Hagedorn, M. Hanisch, G.W.J. Hendrikse, R. Kühl, P. Ollila, P. Pyykkönen, G. Van Der Sangen, 2012. Support for farmers cooperatives. European Commission.

Götz, L, M. Njavro, J.H. Hanf, A. Pieniadz, 2009. Vertical coordination with growers in the supermarket fresh fruit and vegetables supply chain in Croatia. Agrarwirtschaft 58 (2009), Heft 8

Jemrić, Tomislav; Pašalić, Boris; Ilić, Zoran; Drkenda, Pakeza, 2013. Postharvest losses of fruits and vegetables in Croatia, Bosnia and Herzegovina and Serbia // Book of Abstracts of 4th Postharvest Symposium of Western Balkan Countries / Hribar, Janez; Vidrih, Rajko (ur.).

https://www. bib.irb.hr/648925

Koopmans, R. 2006. Starting a cooperative; Farmer-controlled economic initiatives. Agromisa Foundation and CTA, Wageningen

Kotler, Ph., and D. Gertner, 2002. Country as brand, product, and beyond: A place marketing and brand management perspective. HENRY STEWART PUBLICATIONS 1350-231X BRAND MANAGEMENT VOL. 9, NO. 4-5, 249-261 APRIL 2002

Leko Šimić M. and E.M. Hrenek, 2015. Marketing analysis of food as a component of Croatian tourism product. Proceedings of $24^{\text {th }}$ CROMAR congress.

Leko Šimić M. and A. Pap, 2015. Can food be a competitive advantage of Croatian tourism? UDK: 338.48(497.5) Economski Vjestnik/Econviews God. XXIX, BR. 1/2016. str. 9-20 Available at https://hrcak.srce.hr/file/237435 (Accessed on: November 2017)

Lončarić, Ružica, Zdenko Lončarić, Zrinka Tolušić, 2016. What Croatian farmers think about situation in agriculture? University of Josip Juraj Strossmayer in Osijek, Faculty of Agriculture, Osijek, Croatia. European Scientific Journal August 2016 /SPECIAL/ edition ISSN: 1857 - 7881 (Print) e - ISSN 18577431.

https://bib.irb.hr/datoteka/841554.What_Croatian_farmers_think_about_situation_in_agriculture.pdf

Miloš, Sanja, Zorica Jurković, Emilija Raspudić, Zdenko Lončarić, 2014. Risk assessment of pesticide residues in food on Croatian market: should we worry? Journal of Hygienic Engineering and Design, 8 (2014) 74-81. doi:UDC 614.31:632.95.028(497.5)

Ministry of Environmental Protection, 2014. Republic of Croatia, Ministry of Environmental and Nature Protection. Sixth national communication and first biennial report of the republic of Croatia under the United nations framework convention on Climate Change (UNFCCC).

http://unfccc.int/files/national_reports/annex_i_natcom_/application/pdf/hrv_nc6.pdf

Ministry of Tourism, 2016. Tourism in figures, Republic of Croatia; Edition 2017. www.mint.hr

Nedanov, A. and $Đ$ Žutinić, 2015. Cooperative organization as a factor of competitiveness and sustainability in Croatian agriculture. Agriculture \& Forestry, Vol. 61 Issue 1: 113-120, 2015, Podgorica

Porter, Michael E., 1990. The Competitive Advantage of Nations, New York: Free Press

Zondag, Marie-Jose \& Sacha Koppert (Ecorys Netherlands), Carolien de Lauwere (LEI-Wageningen UR), Peter Sloot (Aequator Groen \& Ruimte), Andreas Pauer (Ecorys Brussels), 2015. Young farmers' needs in Croatia; Annex I.4 to the Pilot project: Exchange programmes for young farmers. Study for European Commission, Directorate-General for Agriculture and Rural 
Development. Rotterdam, 25 September 2015.

https://ec. europa.eu/agriculture/sites/agriculture/files/external-studies/2015/youngfarmers/country-reports/annex-i.4-croatia.pdf

\section{Websites used}

Croatian Bureau of Statistics, https://www.dzs.hr/default_e.htm

Eurostat, ef_m_farmleg, http://ec.europa.eu/eurostat/data/database

http://ec.europa.eu/eurostat/statistics-explained/index.php/Energy_production_and_imports http://ec.europa.eu/eurostat/statistics-explained/index.php/Structure_of_agriculture_in_Croatia http://ec.europa.eu/eurostat/statistics-explained/index.php/Unemployment_statistics http://ec.europa.eu/eurostat/statistics-explained/index.php/Water_statistics

FAOSTAT, http://www.fao.org/faostat/en/\#data

http://datatopics.worldbank.org/education/country/croatia

http://www.agrokor.hr/en/companies/

http://www.doingbusiness.org/data/exploreeconomies/croatia

http://www.mcser.org/journal/index.php/mjss/article/viewFile/9365/9044

http://www.mcser.org/journal/index.php/mjss/article/viewFile/9365/9044

http://www.mcser.org/journal/index.php/mjss/article/viewFile/9365/9044

http://www3.weforum.org/docs/GCR2016-2017/05FullReport/TheGlobalCompetitivenessReport20162017_FINAL.pdf

https://ec.europa.eu/agriculture/sites/agriculture/files/external-studies/2006/applicant/croatia_en.pdf https://ec.europa.eu/agriculture/sites/agriculture/files/statistics/rural-development/2013/fulltext_en.pdf

https://ec.europa.eu/agriculture/sites/agriculture/files/statistics/rural-development/2013/fulltext_en.pdf

https://tradingeconomics.com/croatia/unemployment-rate

https://www.cia.gov/library/publications/the-world-factbook/geos/hr.html

https://www.export.gov/article?id=Croatia-Information-and-Communication-Technology

https://www.flandersinvestmentandtrade.com/export/sites/trade/files/market_studies/2015-CroatiaAgriculture.pdf

https://www.flandersinvestmentandtrade.com/export/sites/trade/files/market_studies/2015-CroatiaAgriculture.pdf

https://www.researchgate.net/publication/268278137_Food_Safety_System_in_Croatia

https://www.total-croatia-news.com/business/2443-croatian-agriculture-minister-talks-about-newpolicies

UN COMTRADE Database, https://comtrade.un.org/

World Bank, https://data.worldbank.org/ 


\section{Appendix 1 Selection of products}

In this Appendix we set out the choice for a number of products and determine which countries are important competitors for these products for Croatia. The competitors are used to select relevant market windows in chapter 4 and as benchmark countries part of the analysis on the value chains and the value chain environment in chapter 5 . The selection of products is confined to products that are produced in Croatia. As a first step, six products are chosen that are both important to Croatia in terms of horticultural production as well as important to Croatian consumers, i.e. typical Croatian products. The analysis is focussed on horticultural crops and does not include root crops like potatoes and sugar beet, dry pulses, industrial crops like oil seeds, or other arable crops. Grapes and olives are also excluded as they are mainly processed into wine and olive oil.

To see which products are most interesting from a market opportunities point of view, and select products for further analysis, we analyse production, trade and consumption statistics. The selection of a number of products is necessary in order to limit the amount of information to be assessed and target a number of interesting market windows. However, a certain degree of subjectivity remains in the choice of products. Some products may constitute interesting market windows from an import replacement perspective while others may be more interesting from an export growth perspective. For some products, domestic or foreign consumption markets could be developed while consumption of other products may be expected to decrease in the future despite the development and active pursuit of new growth strategies. Some products may be interesting because they are produced by many growers or in large volumes in Croatia at the moment, while other products may be interesting because they have a high value added and growth potential.

At this point we are limited to the data and time available in the project. Therefore, our selection strategy involves three main criteria: importance of the products to Croatian producers in terms of production volume and growth of production, and share of Croatian consumption volumes in total European consumption for that product as a measure of relative importance of the product to consumption in Croatia. The importance of production is expressed in tonnes, and in terms growth of production between 2005-2008 and 2011-2014. In figure A1.1 and A1.2 the share of Croatia in European production is also given. Keep in mind that Croatia has a share of about $0.57 \%$ of the total European population. The shares in production all lie between 0 and $1.5 \%$. They indicate the relative importance of the products for Croatian producers. 


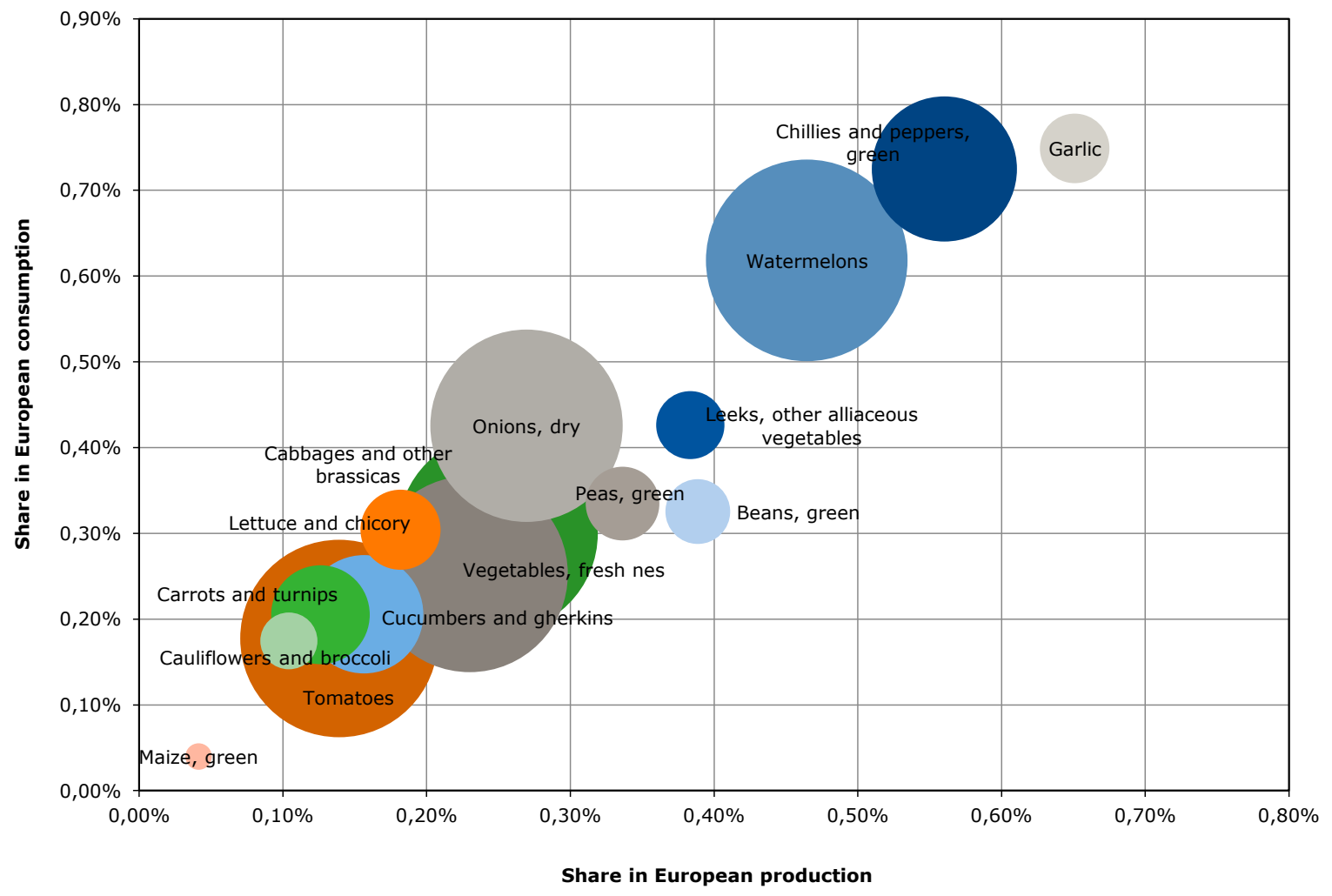

Figure A1.1 Share in European consumption and share in European production in Croatia, in 20122013, and size of production in 2013-2014 (tonnes) as the size of the bubbles, for fruit Source: FAOSTAT, COMTRADE, Calculations Wageningen Economic Research.

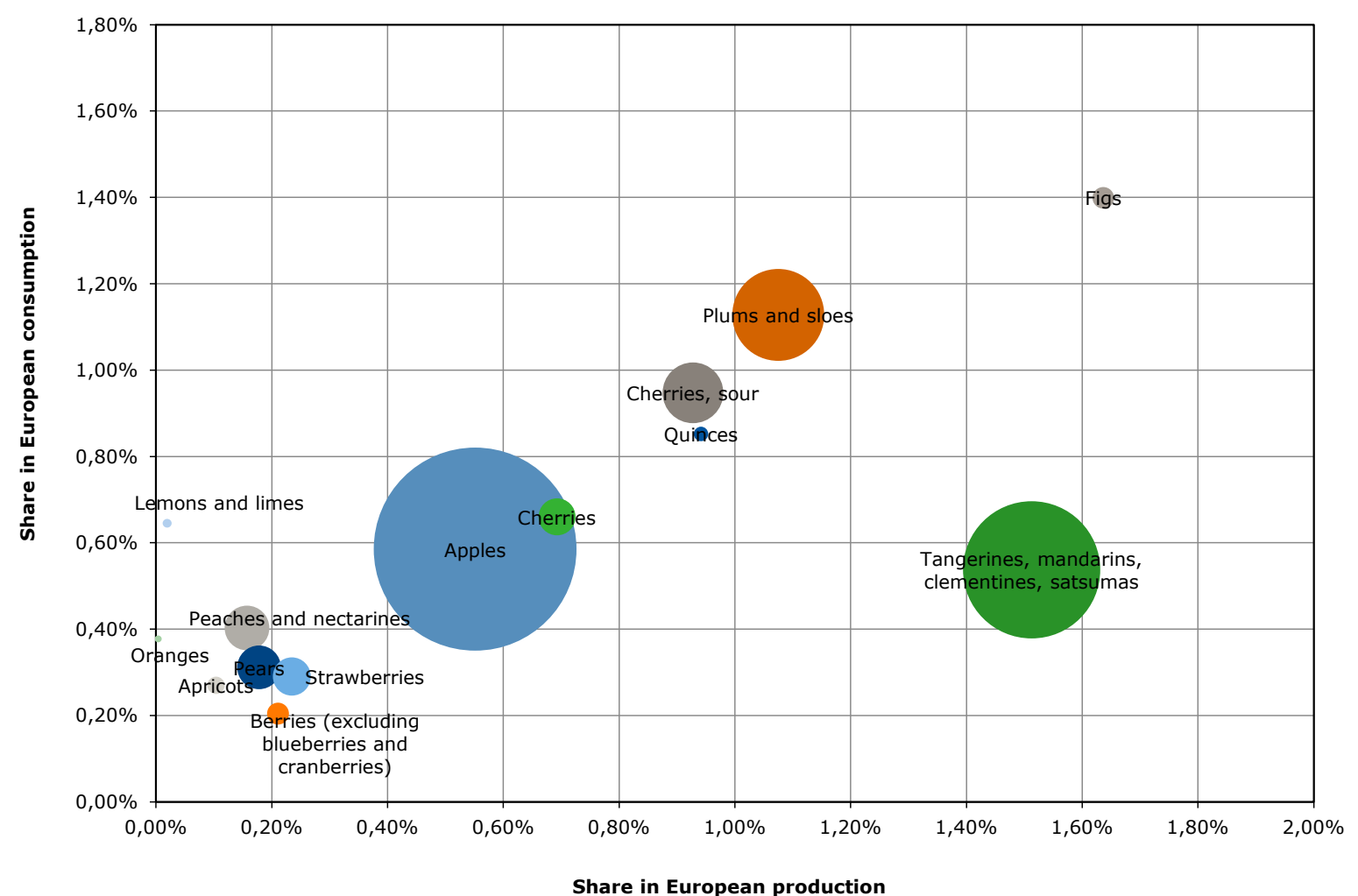

Figure A1.2 Share in European consumption and share in European production in Croatia, in 20122013, and size of production in 2013-2014 (tonnes) as the size of the bubbles, for vegetables Source: FAOSTAT, COMTRADE, Calculations Wageningen Economic Research. 
The data on the three elements are normalised (as the deviation from the average over all products in the subgroups fruit or vegetables divided by the standard deviation). This makes the three elements comparable among each other. After that we have equally weighted the three criteria and calculated scores.

The products with a positive average score on the selection criteria are indicated in bold in the tables below. A number of products, however, are found to be less suitable based on additional information. For vegetables, the production of watermelons and chillies and peppers is quite localised and fluctuating. In Croatia, peppers are mostly destined for processing. Additionally, in recent years the production of watermelons has been decreasing a lot. This shows less prominent from the FAOSTAT data in the tables and charts above, because 2013 and 2014 were years with extraordinary large production volumes for watermelons. After 2014, production fell to 16-19 thousand tonnes in 2015 and 2016 (Eurostat). Tomatoes on the other hand is the largest crop, and is thought to have a lot of growth potential as tourism in Croatia is increasing as well as for exports of (processed) tomatoes.

The final selection of three vegetables products is made from the top-ranking products in the tables below, in consultation with a local consultant and the client: tomatoes, onions and garlic, and cabbages as important and promising vegetable products. And apples, mandarins, and sour cherries as important and promising fruit products.

Table A1.1 Production in 2012-2014, growth of production between 2005-2008 and 2011-2014, and share in European consumption in 2012-2013 in tonnes, and equally weighted scores on normalised values against average of all products, for vegetables products

\begin{tabular}{|c|c|c|c|c|}
\hline & $\begin{array}{r}\text { Production, } \\
2012-2014\end{array}$ & $\begin{array}{r}\text { Growth of } \\
\text { production } \\
2005-2008 / \\
2011-2014\end{array}$ & $\begin{array}{r}\text { Share in European } \\
\text { consumption, } \\
2012-2013\end{array}$ & $\begin{array}{r}\text { Weighted } \\
\text { score }\end{array}$ \\
\hline & & & & Average \\
\hline Tomatoes & 27341 & $-14 \%$ & $0.2 \%$ & 0.17 \\
\hline Onions, dry & 27025 & $4 \%$ & $0.4 \%$ & 0.69 \\
\hline Cabbages and other brassicas & 27011 & $-36 \%$ & $0.3 \%$ & 0.19 \\
\hline Watermelons & 26547 & $-9 \%$ & $0.6 \%$ & 0.89 \\
\hline Vegetables, fresh nes & 24224 & $132 \%$ & $0.3 \%$ & 1.26 \\
\hline Chillies and peppers, green & 15044 & $-57 \%$ & $0.7 \%$ & 0.36 \\
\hline Carrots and turnips & 9819 & $2 \%$ & $0.2 \%$ & -0.22 \\
\hline Cucumbers and gherkins & 9027 & $-39 \%$ & $0.2 \%$ & -0.54 \\
\hline Lettuce and chicory & 4830 & $-34 \%$ & $0.3 \%$ & -0.48 \\
\hline Garlic & 3876 & $-12 \%$ & $0.7 \%$ & 0.37 \\
\hline Peas, green & 3796 & $-45 \%$ & $0.3 \%$ & -0.54 \\
\hline Leeks, other alliaceous veg. & 3422 & $-43 \%$ & $0.4 \%$ & -0.38 \\
\hline Beans, green & 2978 & $-54 \%$ & $0.3 \%$ & -0.65 \\
\hline Cauliflowers and broccoli & 2423 & $-33 \%$ & $0.2 \%$ & -0.75 \\
\hline Maize, green & 506 & $1 \%$ & $0.0 \%$ & -0.78 \\
\hline
\end{tabular}

Source: FAOSTAT, COMTRADE, calculations Wageningen Economic Research. 
Table A1.2 Production in 2012-2014, growth of production between 2005-2008 and 2011-2014, and share in European consumption in 2012-2013 in tonnes, and equally weighted scores on normalised values against average of all products, for fruit products

\begin{tabular}{|c|c|c|c|c|}
\hline & $\begin{array}{r}\text { Production, } \\
2012-2014\end{array}$ & $\begin{array}{r}\text { Growth of } \\
\text { production } \\
2005-2008 / \\
2011-2014\end{array}$ & $\begin{array}{r}\text { Share in European } \\
\text { consumption, } 2012- \\
2013\end{array}$ & Weighted score \\
\hline & & & & Average \\
\hline Apples & 91770 & $28 \%$ & $0.6 \%$ & 1.23 \\
\hline Plums and sloes & 20796 & $-50 \%$ & $1.1 \%$ & 0.19 \\
\hline Cherries, sour & 8868 & $73 \%$ & $0.9 \%$ & 0.89 \\
\hline Peaches and nectarines & 5766 & $6 \%$ & $0.4 \%$ & -0.22 \\
\hline Pears & 4683 & $-32 \%$ & $0.3 \%$ & -0.63 \\
\hline Cherries & 4151 & $-18 \%$ & $0.7 \%$ & -0.20 \\
\hline Berries, a) & 1333 & $4 \%$ & $0.2 \%$ & -0.47 \\
\hline Apricots & 838 & $-19 \%$ & $0.3 \%$ & -0.61 \\
\hline Quinces & 641 & $42 \%$ & $0.9 \%$ & 0.45 \\
\hline Lemons and limes & 214 & $-50 \%$ & $0.6 \%$ & -0.53 \\
\hline Oranges & 185 & $-60 \%$ & $0.4 \%$ & -0.86 \\
\hline
\end{tabular}

a) (excl. blueberries, cranberries).

Source: FAOSTAT, COMTRADE, calculations Wageningen Economic Research. 


\section{Appendix 2 Benchmark countries}

In this section we show which countries are the major suppliers of the European and Croatian markets for the selected products. The vast majority of exports of Croatian horticultural products is destined for nearby countries. On these markets, largely the same competitors are active as in the rest of the European market, which is defined as the whole continent of Europe including Russia. However, because the home market is very important for Croatian produce, we also take into account the countries that specifically export to Croatia and which are the major competitors for Croatian on the home market. The top-3 exporters to Europe and top-3 exporters to Croatia (discarding overlapping countries) are selected as benchmark countries. If countries are not producing the products themselves, but are merely re-exporting, these countries are excluded. 


\section{Tomatoes}

The Netherlands, Spain, Morocco and Turkey are the largest exporters of tomatoes to the European market. Italy is also a large producer of tomatoes but does not export much. On the Croatian market however, Italy is the second largest supplier after the Netherlands.

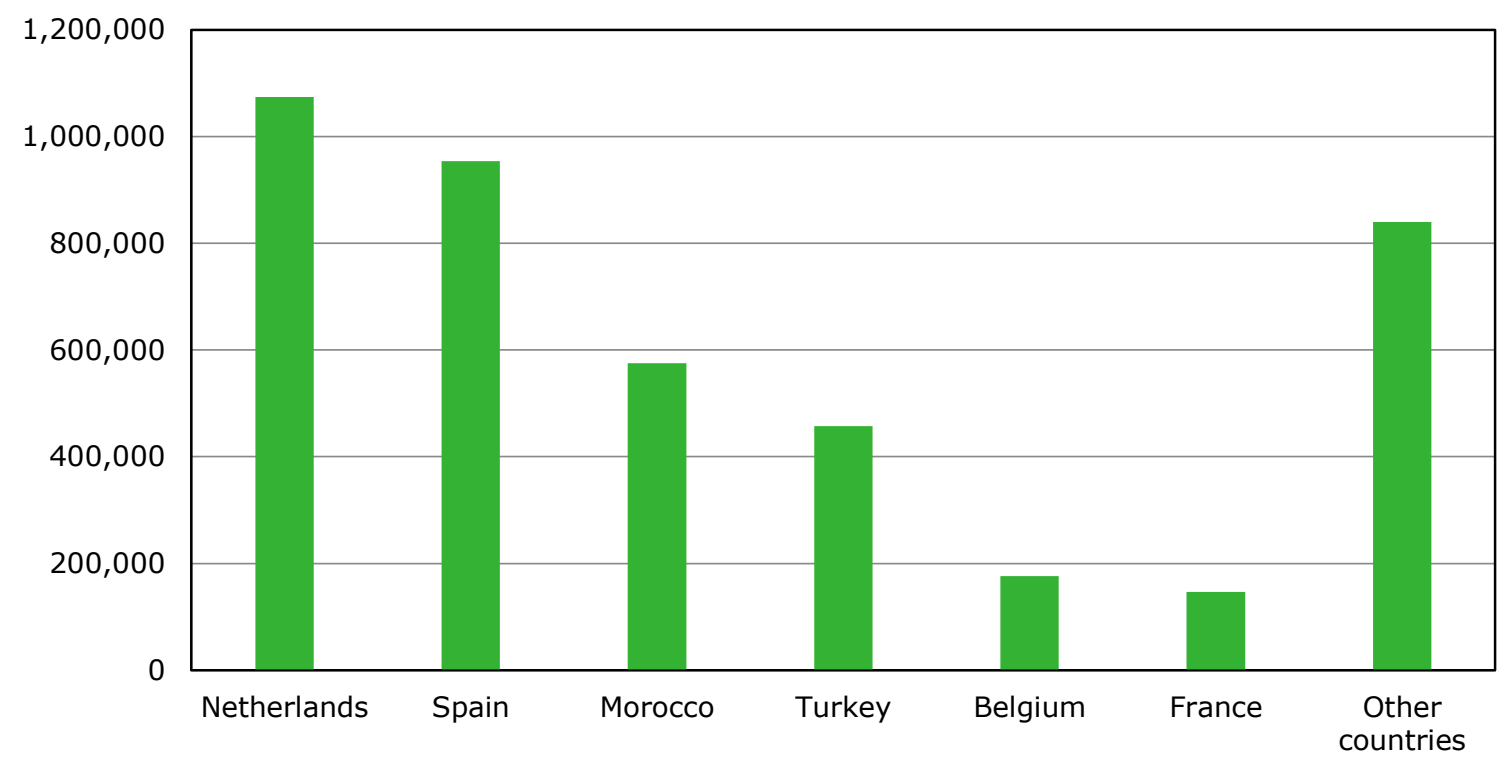

Figure A2.1 Import volume of tomatoes in Europe by country of origin, in tonnes, average 2013-2015 Source: UN Comtrade, calculations Wageningen Economic Research.

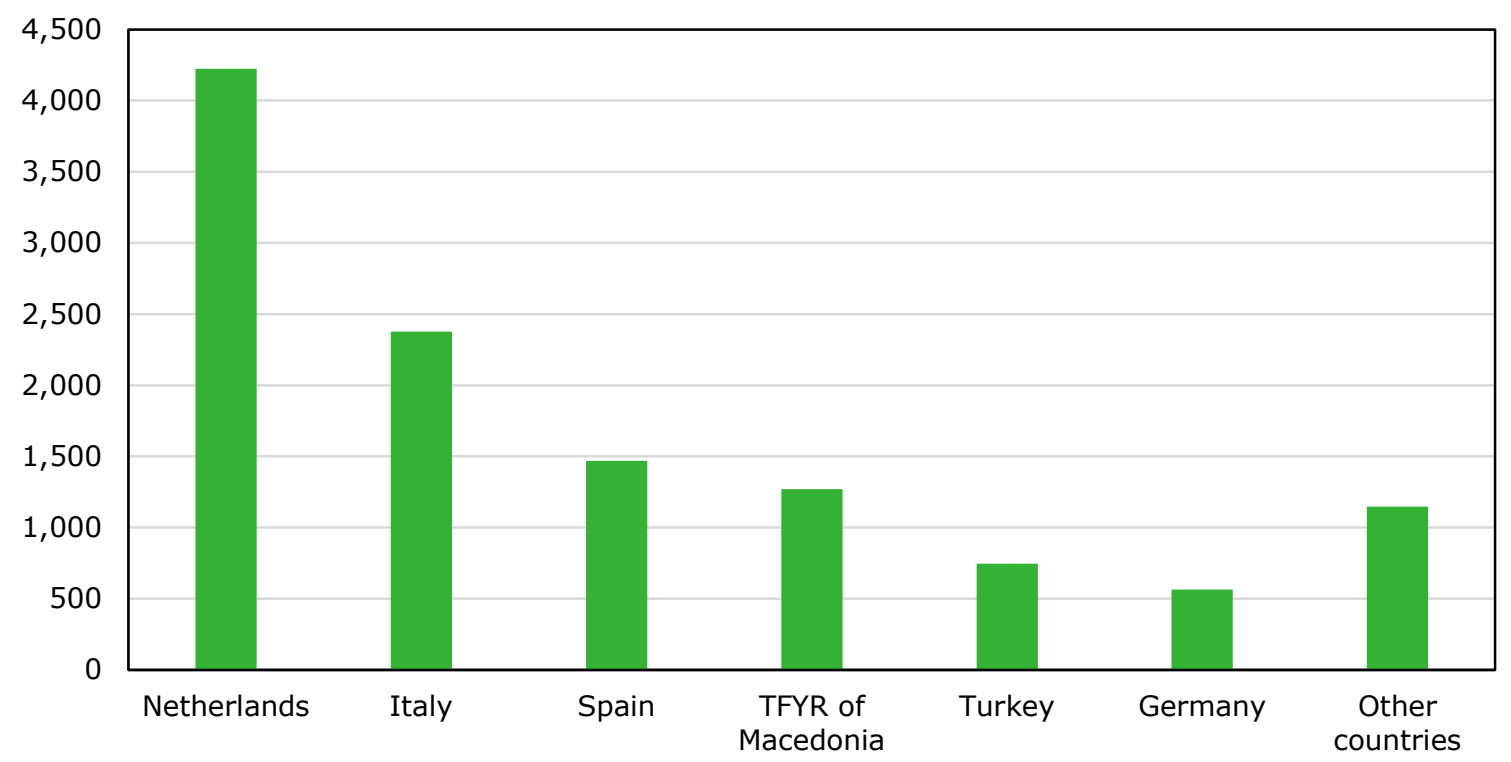

Figure A2.2 Import volume of tomatoes in Croatia by country of origin, in tonnes, average 2013-2015 Source: UN Comtrade, calculations Wageningen Economic Research.

As benchmark countries for tomatoes we select the top-3 countries that export to the European market as a whole plus the top-3 countries that export to Croatia. If these countries overlap, we select additional benchmark countries from the top- 6 exporters to Croatia to obtain a total of six benchmark countries. For tomatoes this results in the following competing countries: the Netherlands, Spain, Italy, Turkey, Morocco, and TFYR of Macedonia. Other countries include all other European imports of the product, or in figures regarding Croatian imports, all other imports from other countries of origin. 


\section{Cabbages}

Following the same method as for tomatoes, we select the following benchmark countries for cabbage: Spain, Poland, the Netherlands, TFYR of Macedonia, Bosnia Herzegovina, and Serbia.

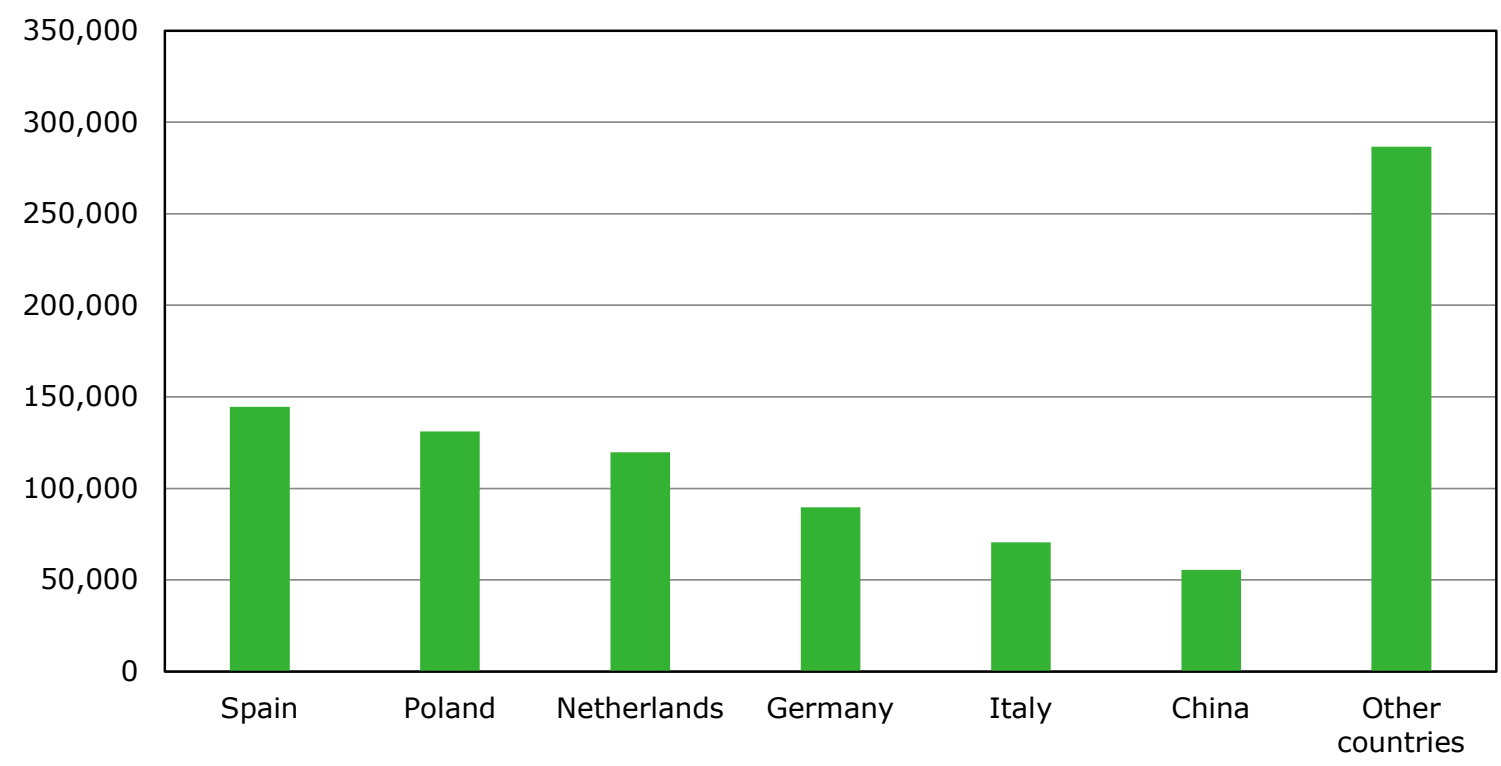

Figure A2.3 Import volume of cabbage in Europe by country of origin, in tonnes, average 2013-2015 Source: UN Comtrade, calculations Wageningen Economic Research.

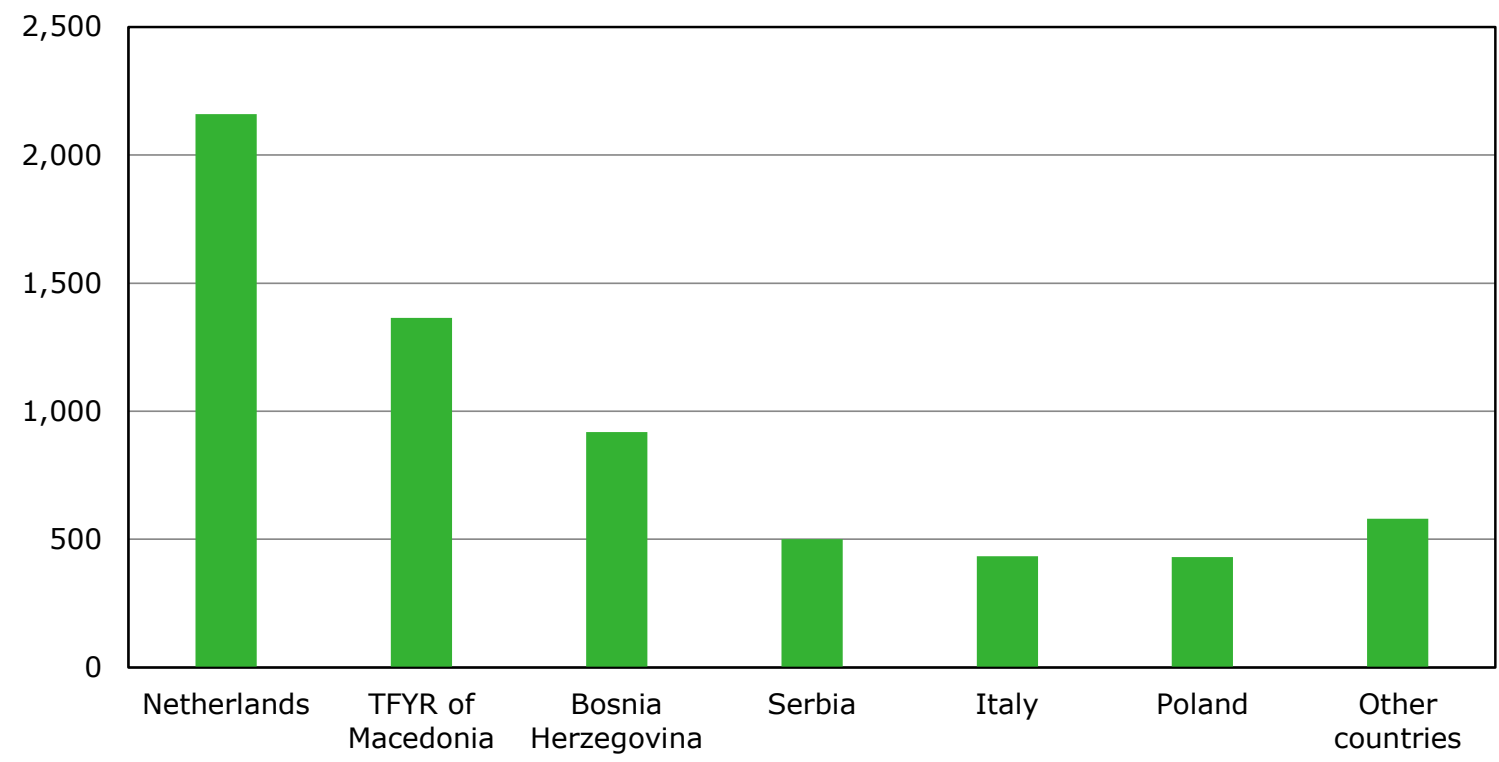

Figure A2.4 Import volume of cabbage in Croatia by country of origin, in tonnes, average 2013-2015 Source: UN Comtrade, calculations Wageningen Economic Research. 


\section{Onions}

We select the following benchmark countries for onions: the Netherlands, Spain, Egypt, Austria, Germany and Slovenia.

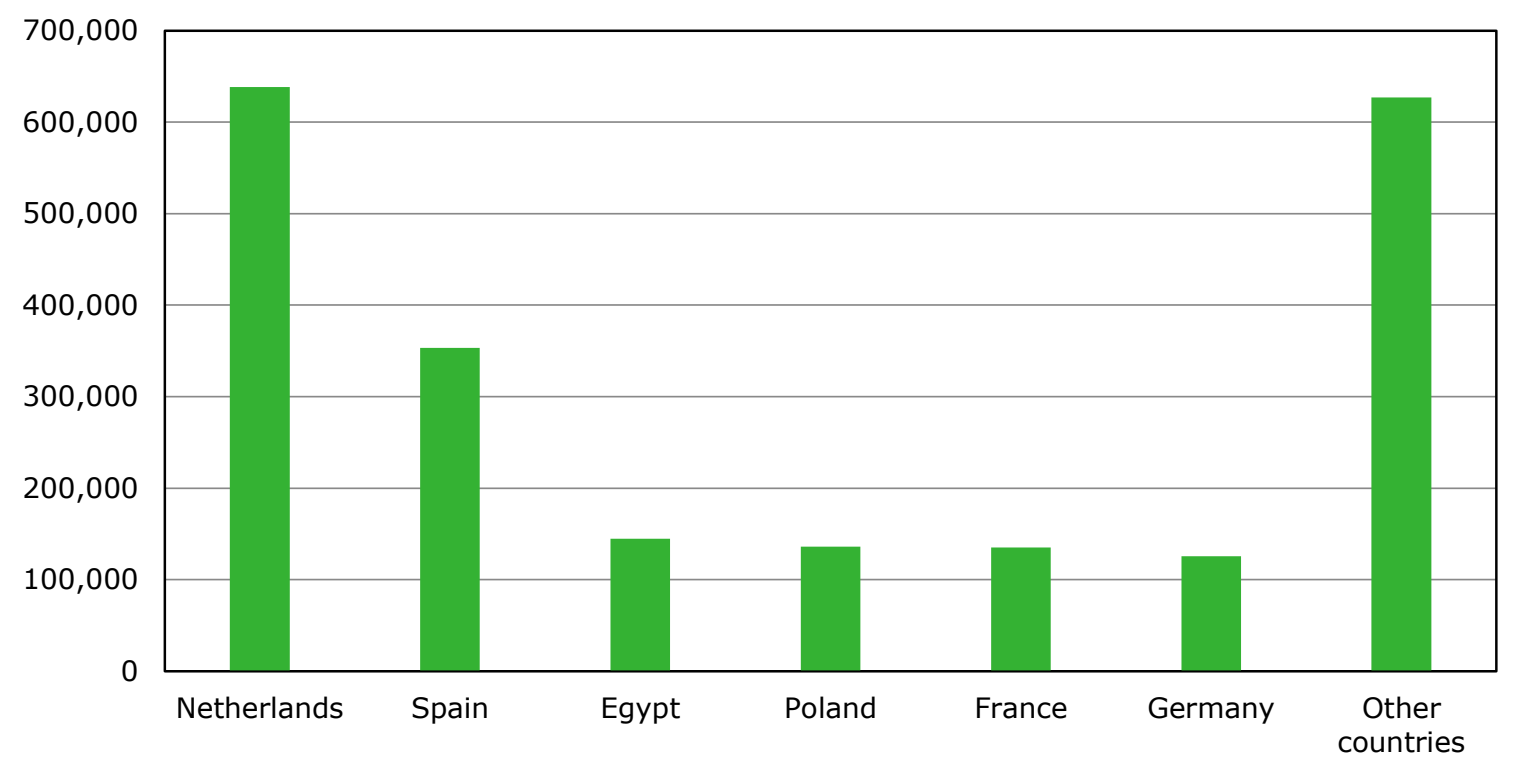

Figure A2.5 Import volume of onions and shallots in Europe by country of origin, in tonnes, average 2013-2015

Source: UN Comtrade, calculations Wageningen Economic Research.

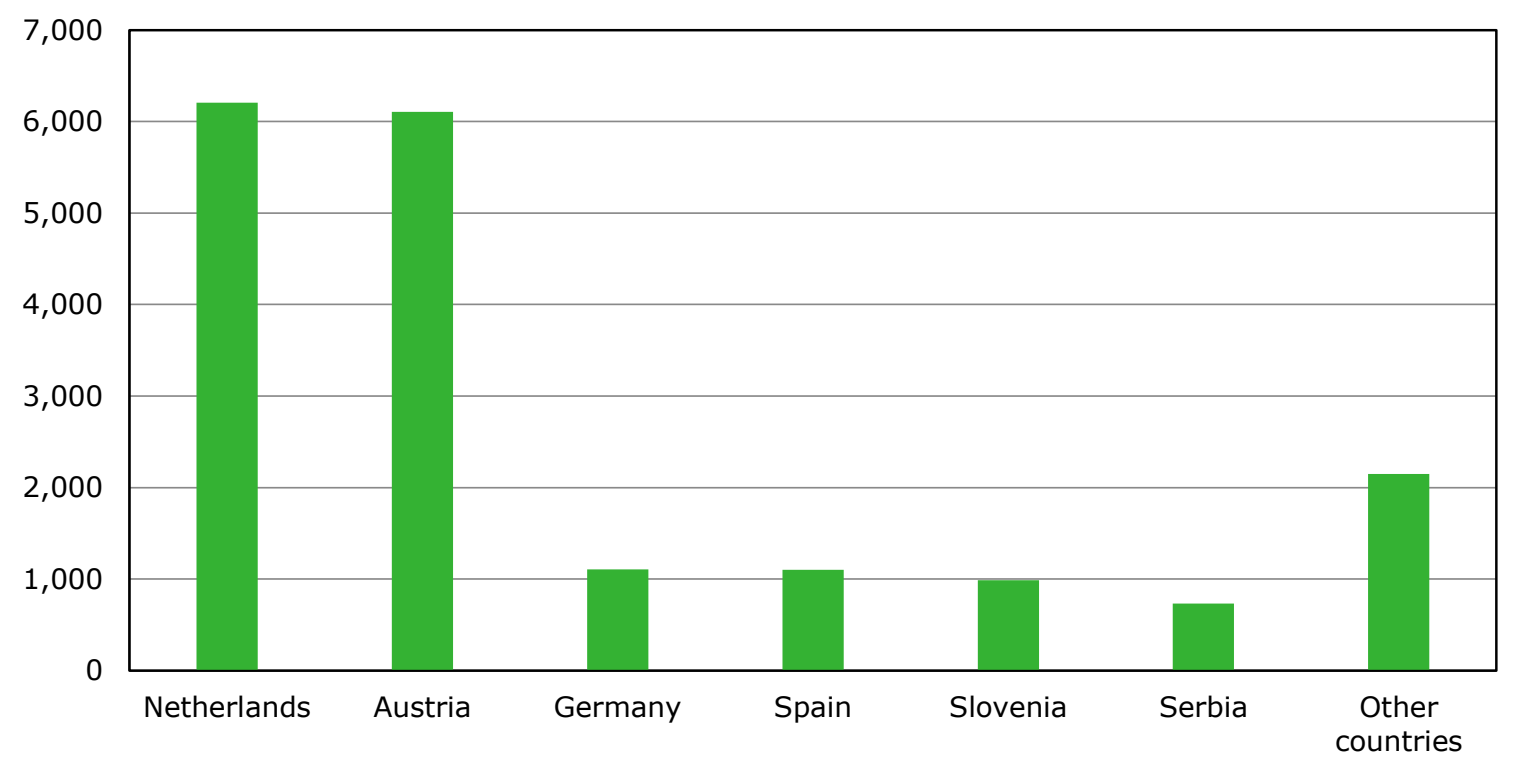

Figure A2.6 Import volume of onions and shallots in Croatia by country of origin, in tonnes, average 2013-2015

Source: UN Comtrade, calculations Wageningen Economic Research. 


\section{Garlic}

For garlic, the following benchmark countries are selected: China, Spain, France, Slovenia, Italy, and Argentina. The Netherlands and Germany are excluded as these countries hardly produce any garlic themselves.

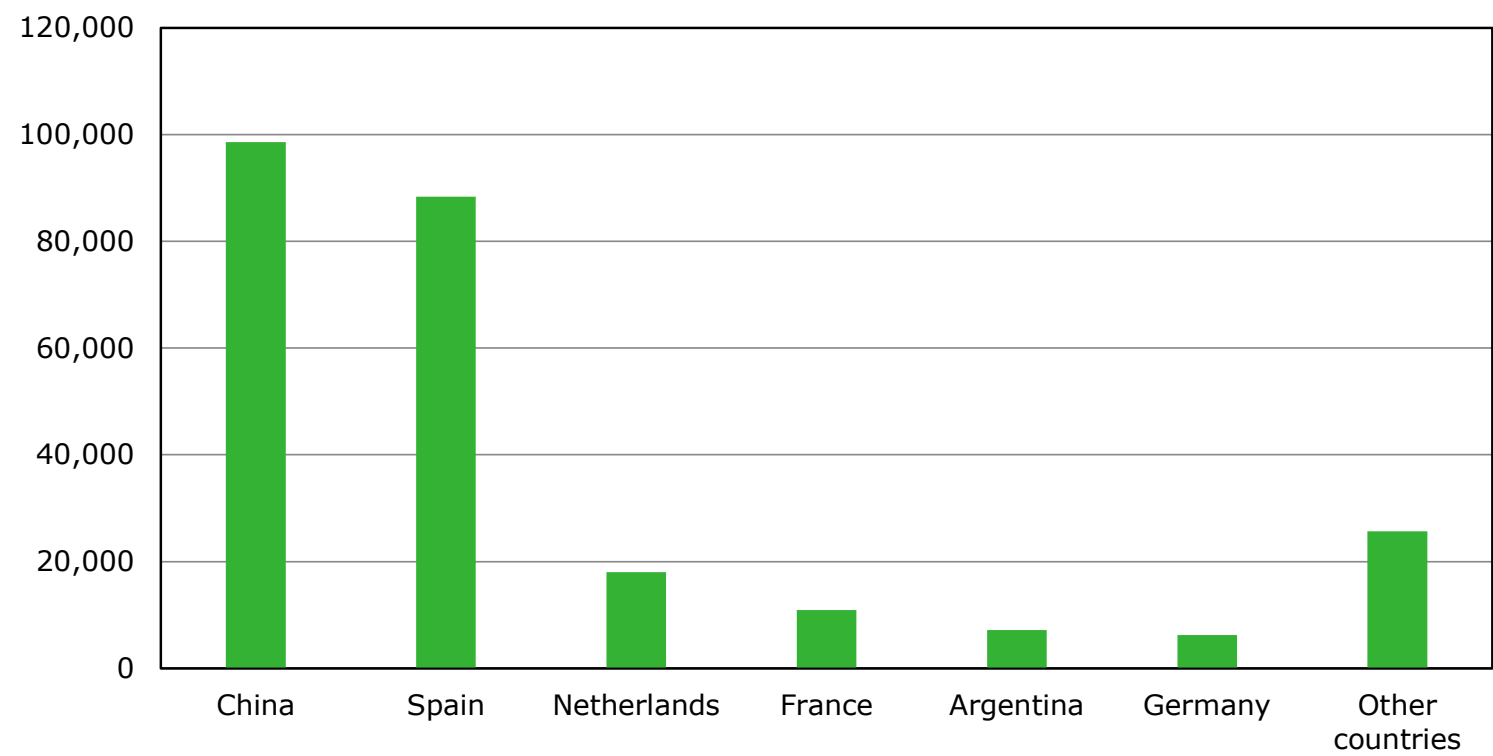

Figure A2.7 Import volume of garlic in Europe by country of origin, in tonnes, average 2013-2015 Source: UN Comtrade, calculations Wageningen Economic Research.

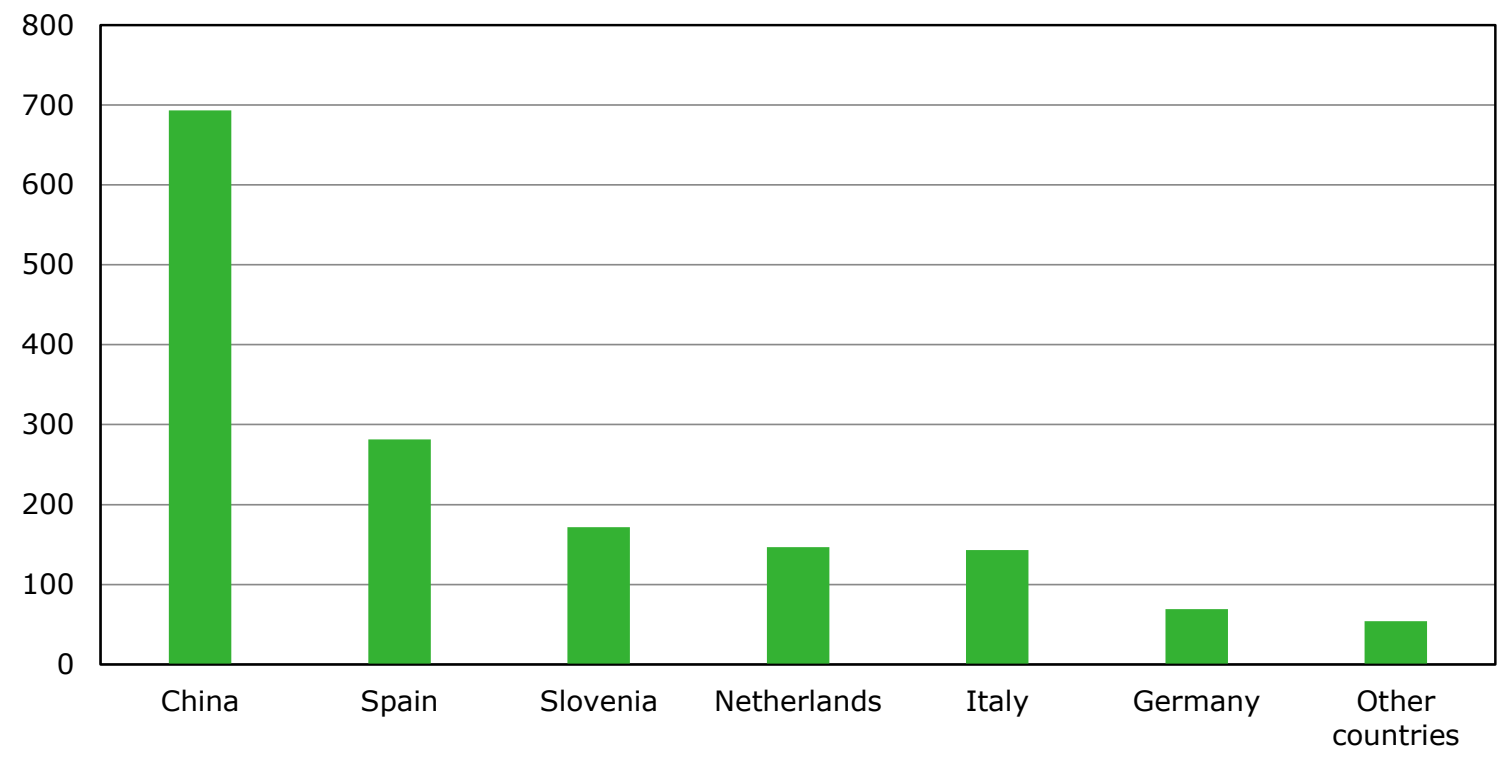

Figure A2.8 Import volume of garlic in Croatia by country of origin, in tonnes, average 2013-2015 Source: UN Comtrade, calculations Wageningen Economic Research. 


\section{Apples}

Following the same method, we select the following benchmark countries for apples: Poland, Italy, and France as the top-exporters to the European market, and Slovenia, Austria and Germany as the three additional largest exporters to Croatia.

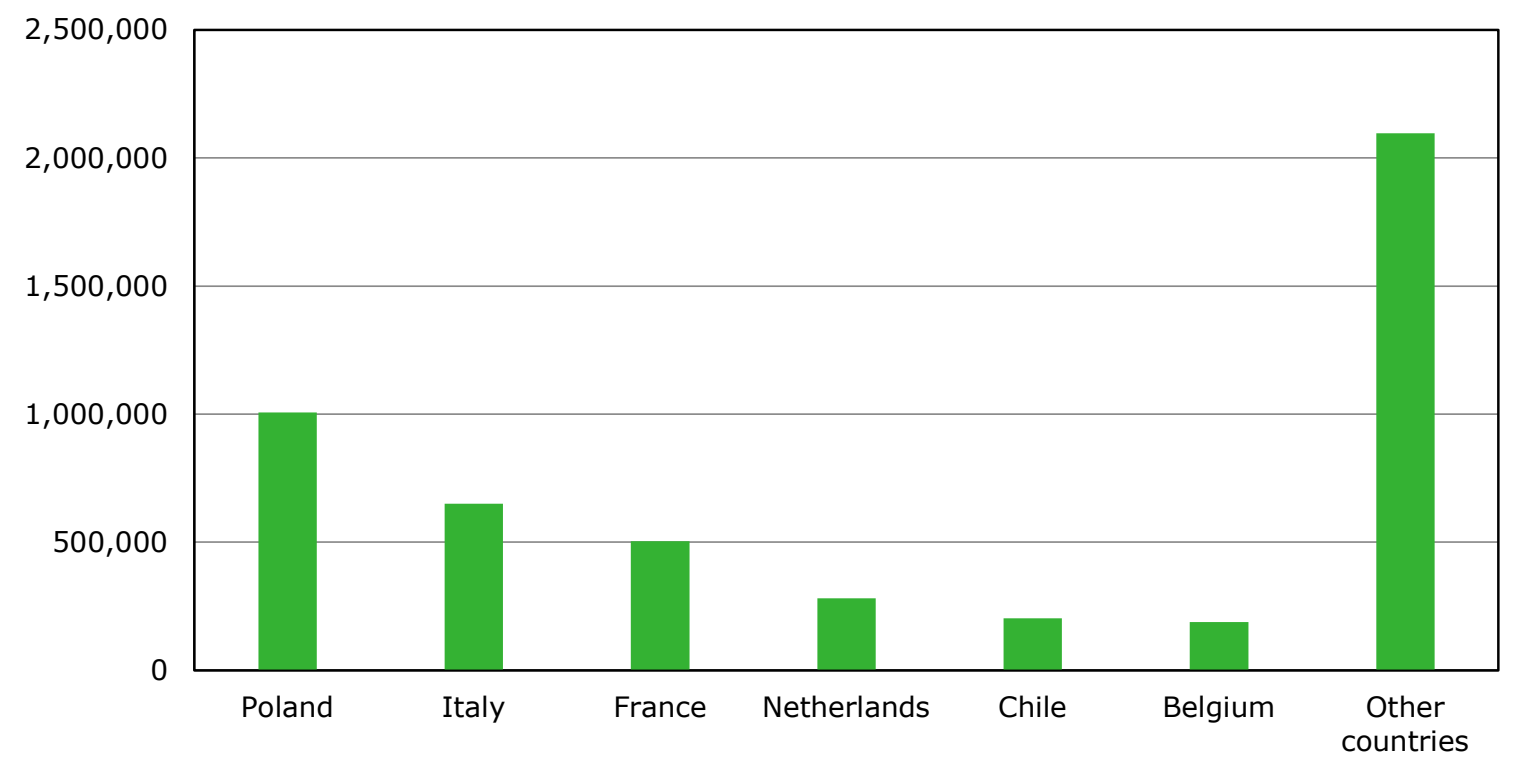

Figure A2.9 Import volume of apples in Europe by country of origin, in tonnes, average 2013-2015 Source: UN Comtrade, calculations Wageningen Economic Research.

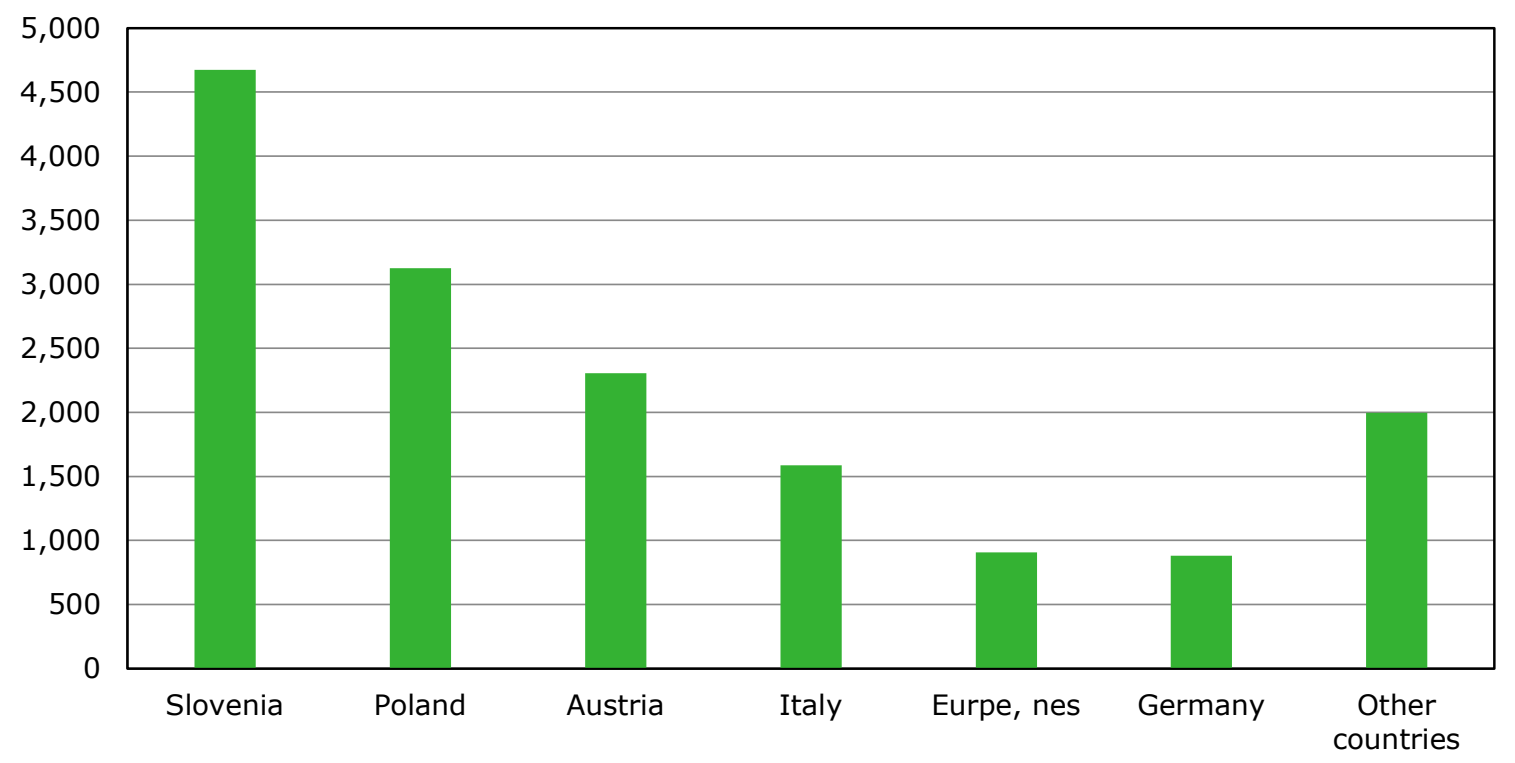

Figure A2.10 Import volume of apples in Croatia by country of origin, in tonnes, average 2013-2015 Source: UN Comtrade, calculations Wageningen Economic Research. 


\section{Mandarins}

The following benchmark countries are selected for mandarins: Spain, Turkey and Morocco as the major suppliers to the European market, and Italy and Greece as additional suppliers to the Croatian market. Germany and also Slovenia are not producing mandarins according to FAO. As a sixth benchmark country we include South Africa.

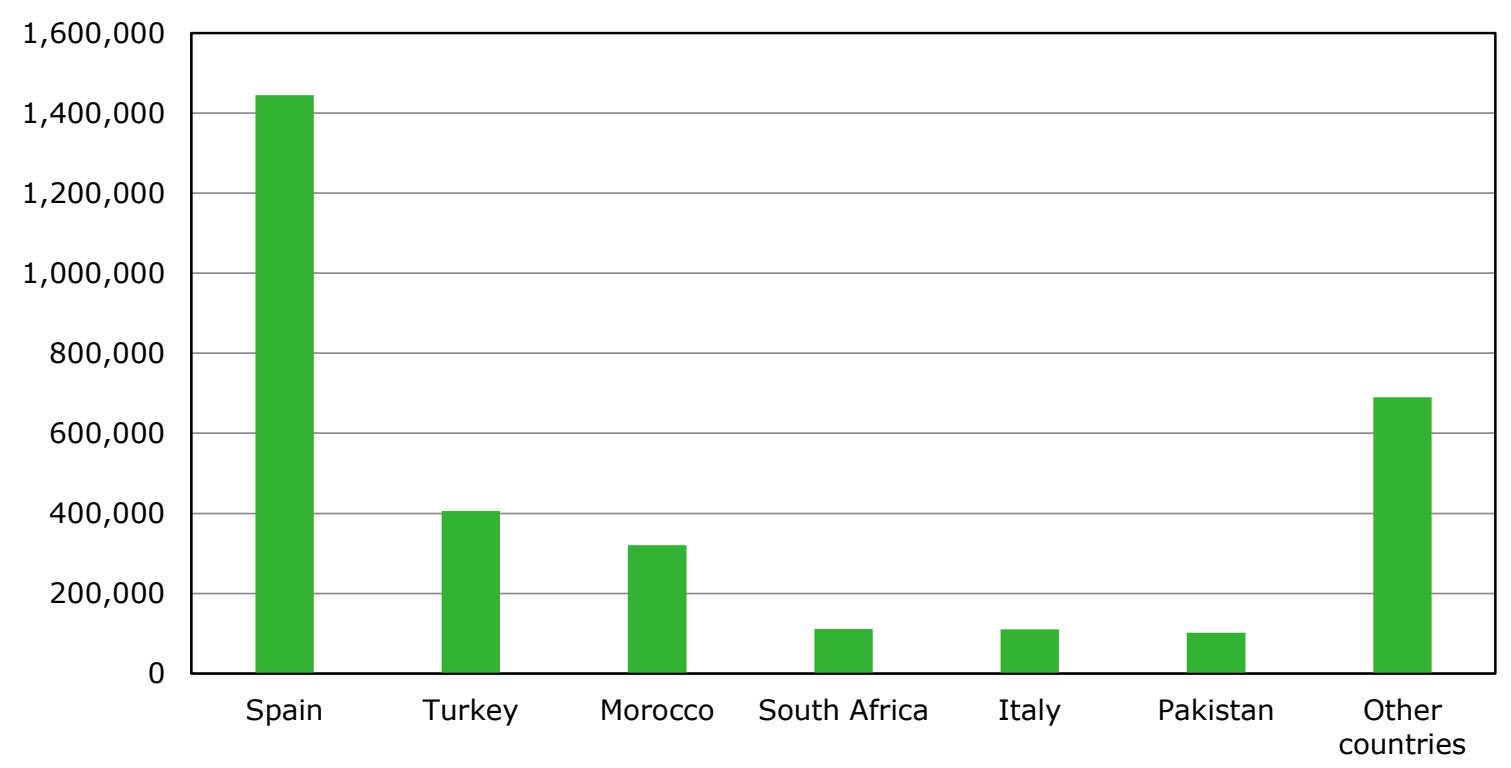

Figure A2.11 Import volume of mandarins in Europe by country of origin, in tonnes, average 20132015

Source: UN Comtrade, calculations Wageningen Economic Research.

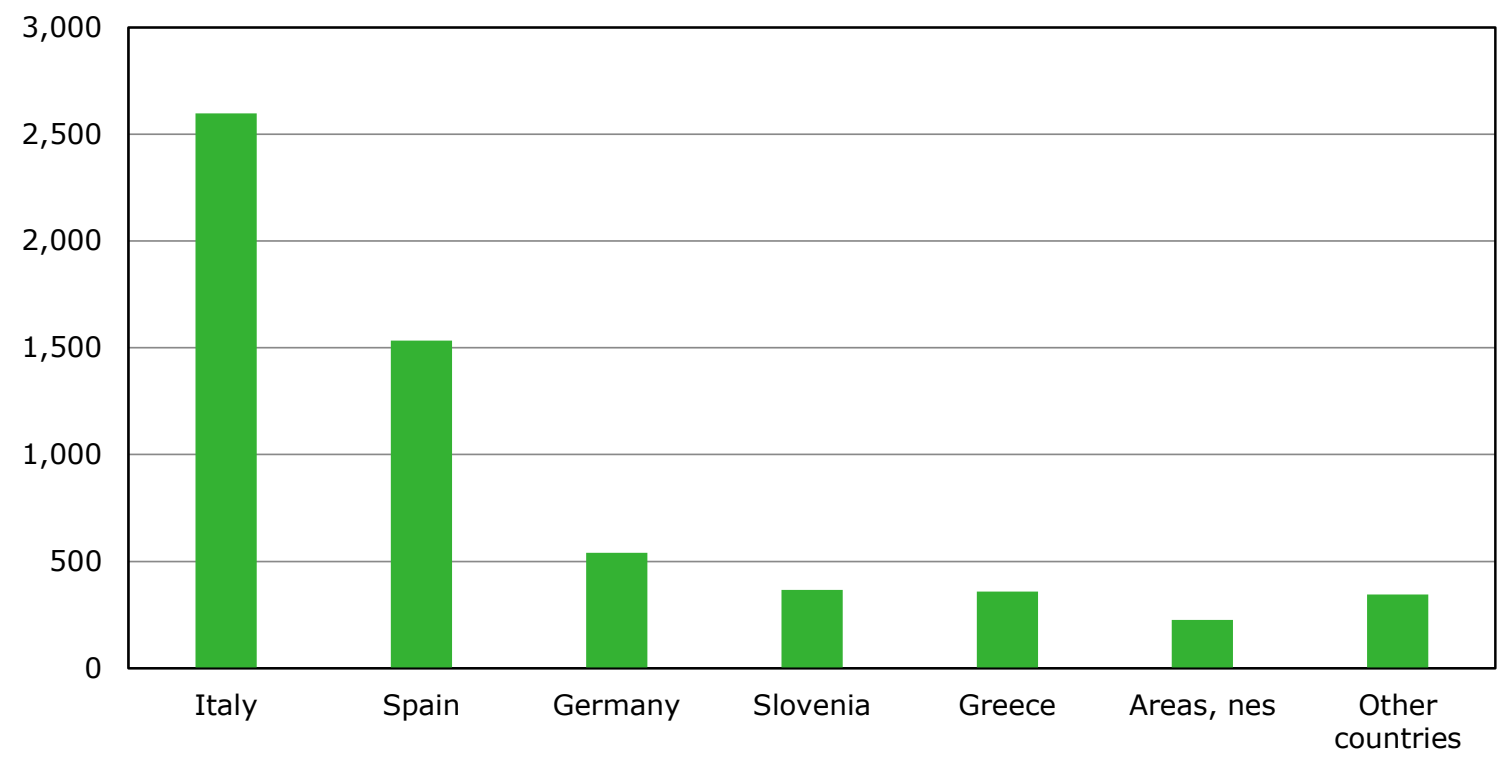

Figure A2.12 Import volume of mandarins in Croatia by country of origin, in tonnes, average 20132015

Source: UN Comtrade, calculations Wageningen Economic Research. 


\section{Sour cherries}

Finally, for sour cherries we select the following benchmark countries: Hungary, Poland, Serbia, Bosnia Herzegovina, TFYR of Macedonia, and Italy. Slovenia is also a large producer of cherries with quite high yields. But it is not primarily producing sour cherries and not exporting anything in the period studied and hence not included as a benchmark country.

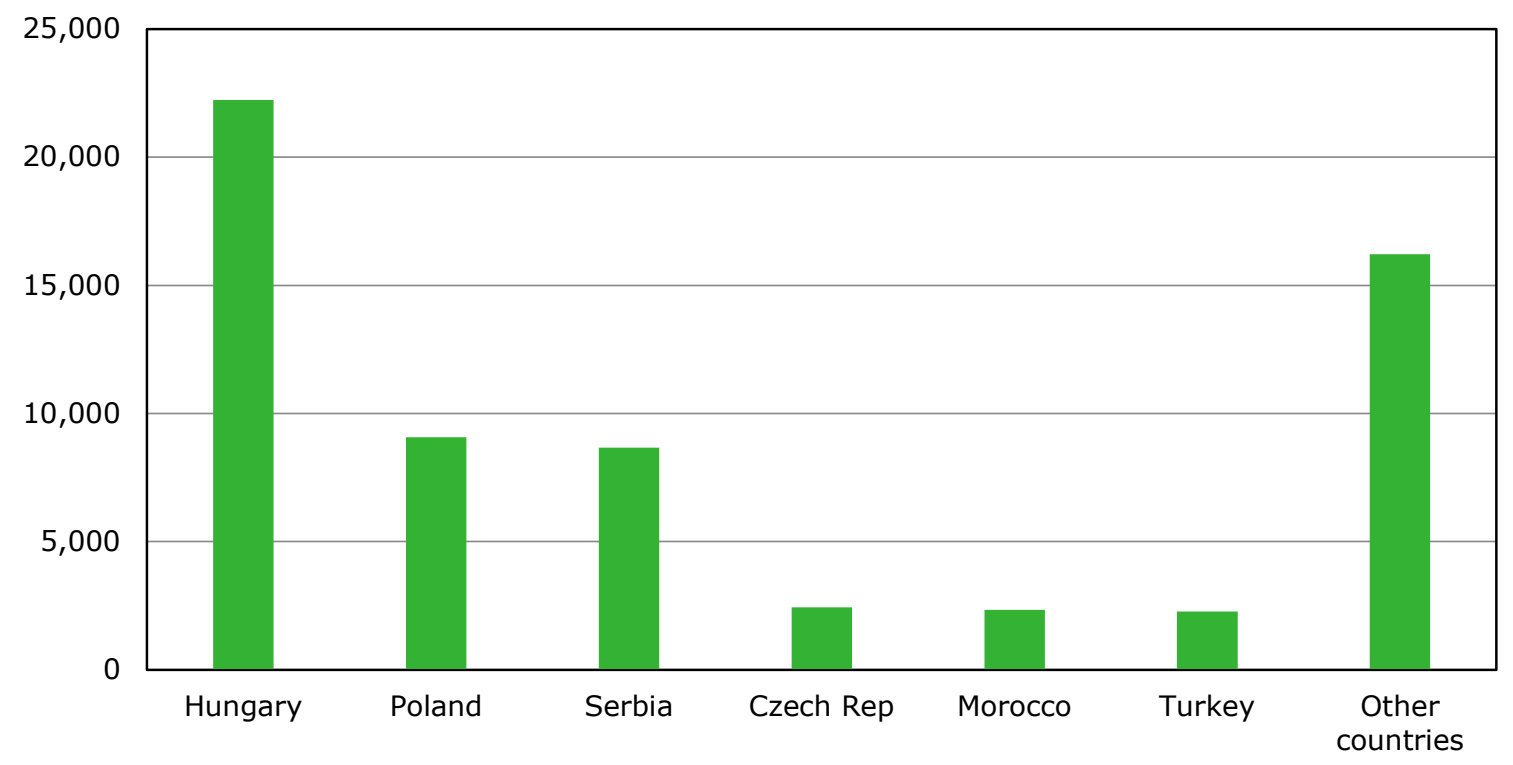

Figure A2.13 Import volume of cherries in Europe by country of origin, in tonnes, average 20132015

Source: UN Comtrade, calculations Wageningen Economic Research.

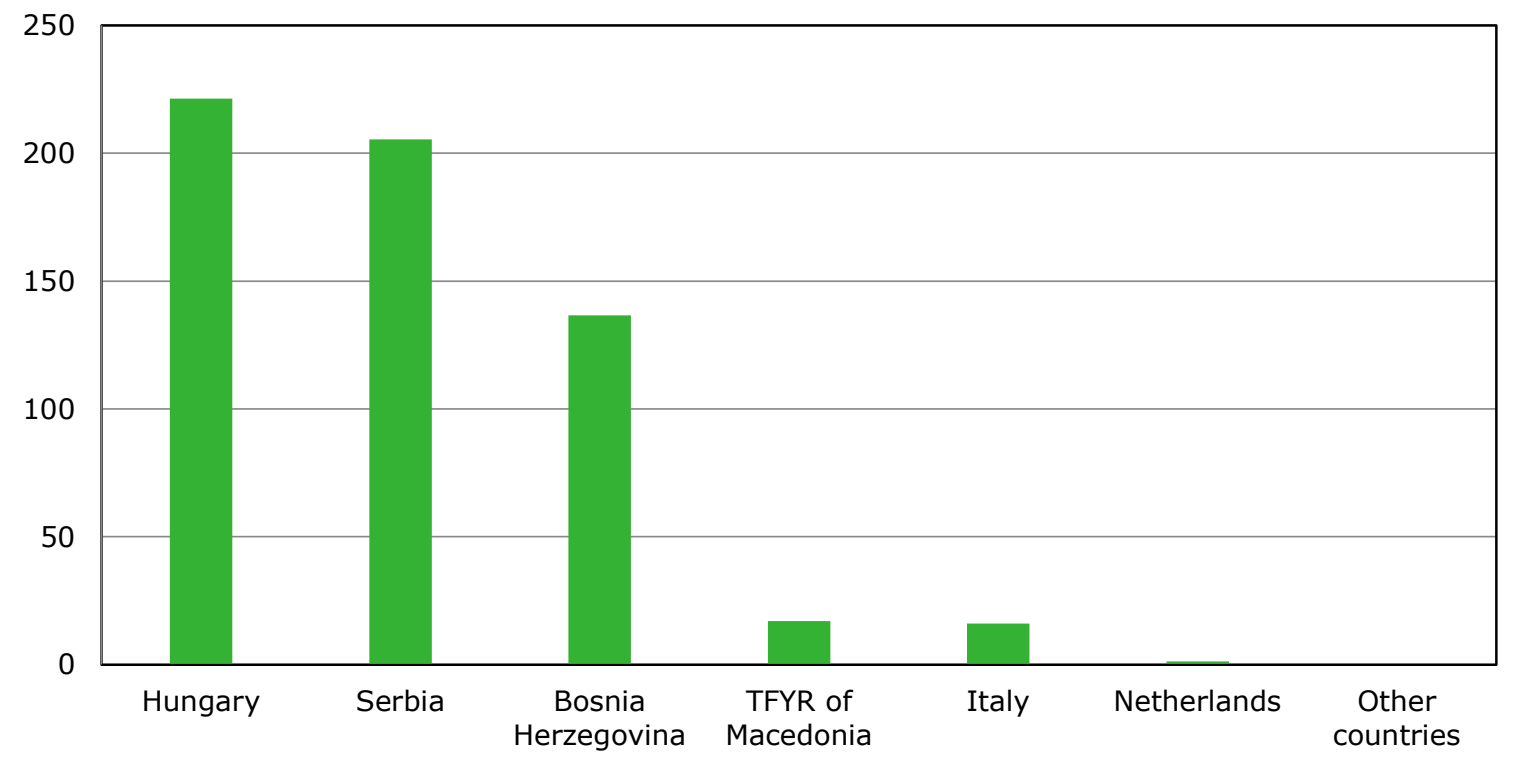

Figure A2.14 Import volume of cherries in Croatia by country of origin, in tonnes, average 20132015.

Source: UN Comtrade, calculations Wageningen Economic Research. 


\section{Appendix 3 International market windows}

\section{Introduction}

In this chapter we explore which countries are potentially attractive export markets for Croatia. A number of market windows are determined and analysed in terms of size, growth, concentration, price level and other indicators that can be used to show market attractiveness and business position of Croatia.

In the analysis in this chapter we focus on fresh produce, although we do realise that some produce may be processed. Specifically tomatoes, cabbages, apples and cherries are processed into several products. According to Levaj et al. (2012), mandarins are mainly produced for fresh consumption. Mandarin juice is not much produced in Croatia and is not generally available in the market. ${ }^{37}$

\section{Methodology}

In step 1 we determine the market attractiveness (MA) for the selected products of all countries in the world for which international trade data are available from UN Comtrade (about 260 countries). Also we determine the business position (BP) of Croatia on these markets.

The market attractiveness is calculated on the basis of 5 indicators: the SIZE of the import market for the specific products in 2013-2015 in euros, the absolute GROWTH of the import markets between 2009-2011 and 2013-2015 in euros, the STABILITY of the import markets in the period 2005-2015, the average PRICE on these import markets in 2013-2015, and the average CONCENTRATION rate of the different import markets for the period 2013-2015. The overall judgment of the attractiveness of each country is determined by a weighted sum the scores of all indicators.

The market stability is calculated as the negative $(-1)$ of the standard error of the OLS estimation of the line across the observed values of imports. A higher standard error means a lower predictability of trade and less stability. Taking the standard error instead of e.g. the coefficient of variation means that a steady upward or downward trend is not seen as an instable market.

The concentration rate is calculated as the sum of squares of all the market shares of all the exporting countries to the respective markets. This concentration rate ranges between 0 and 1 , and is similar to the Herfindahl-Hirschman index ( $\mathrm{HHI}$ ) except for that it is applied to countries instead of companies. A higher index indicates a higher rate of market concentration. A lower index indicates a more competitive market (more and smaller suppliers). For our analysis we consider a high market concentration as less favourable because there are stronger competitors on such a market. A low degree of concentration would also indicate strong competition from many suppliers. In practice, for the products considered, the concentration rates are mostly between 0.2 and 0.5 indicating a relatively low number of supplying countries active on the market. This index does however not tell us anything about the numbers of companies that are active on the market.

For stability and concentration a higher value is deemed less favourable, whereas for the other indicators a higher value is more favourable. All five indicators are rescaled between 0 (least favourable) and 5 (most favourable) based on the market's score relative to the minimum and maximum values found in all countries. Next, the five indicators are weighted against each other. The

\footnotetext{
${ }^{37}$ http://agris.fao.org/agris-

search/search.do;jsessionid=DE7ABBF9AB4396400A50D23BFBDD8642? request_locale=ru\&_recordID=RS2013060137\&que $r y=\&$ sourceQuery $=\&$ sortField $=$ \&sortOrder $=$ \&agrovocString $=$ \&advQuery $=$ \&centerString=\&enableField $=$
} 
applied weights are based on a qualitative assessment of the relative importance, the mutual relationship between the indicators and the variations in the underlying data. The weight applied are as follows: SIZE 0.25, GROWTH 0.25, STABILITY 0.125, PRICE 0.25, CONCENTRATION 0.125.

Contrary to the market attractiveness, the business position refers not to the overall attractiveness of a country's import market but to the position that Croatia has on that particular market. The business position is calculated on the basis of three indicators: the SIZE of the imports from Croatia in euros, the MARKET SHARE of Croatia on the import market in the country, and the average PRICE of imports from Croatia relative to the price of all imports. Again, the three indicators are rescaled between 0 and 5. The applied weights for business position are: SIZE 0.25, MARKET SHARE 0.25, and PRICE 0.5.

In step 3 we select a top-20 countries on the basis of the sum of a) market attractiveness, and b) business position (we weight both aspects equally although other relative importance may also be applied), and c) whether or not the countries have an existing trade relationship with the benchmark countries. To avoid that our analysis yields market windows that are not really attractive because trade would not even be feasible (e.g. due to high transportation costs) we include only those countries that already import a certain amount of produce from the benchmark countries or from Croatia. The thresholds are set depending on the type of product (apples and mandarins are traded over longer distances while e.g. cherries are rarely traded over long distances), and the overall size of trade flows. The thresholds applied are as follows:

Table A3.1 Threshold to include countries in MABA analysis

\begin{tabular}{ll} 
Product & $\begin{array}{l}\text { Minimum average import from benchmark countries } \\
\text { or Croatia in 2013-2015 to include in MABA, } \mathrm{C}\end{array}$ \\
\hline Tomatoes & $2 \mathrm{~m}$ \\
\hline Cabbages & $1 \mathrm{~m}$ \\
\hline Onions & $1 \mathrm{~m}$ \\
\hline Garlic & 100,000 \\
\hline Apples & $2 \mathrm{~m}$ \\
\hline Mandarins & $2 \mathrm{~m}$ \\
\hline Sour cherries & 50,000 \\
\hline
\end{tabular}

This is done to exclude tiny island states that import very small amounts against very high prices due to transportation costs, or countries on the other end of the world that are supplied from totally different regions. The top-20 countries are presented in tables (see Appendix 4) and a bubble chart, with market attractiveness and business position on the horizontal and vertical axes, and total size of the import market as the bubble sizes. 


\section{Tomatoes}

In the figure below, the first 10 market windows for tomatoes are shown. An overview of the top-20 countries with the highest total scores on market attractiveness and business position is given in Appendix 4. On the vertical axis the business position of Croatia is shown on a scale of 0-5. The highest score of 5 indicates an optimal position, relative to Croatia's position on all other markets, in terms value of trade, the market share of Croatia, and prices of imports from Croatia relative to the world market price. A score of 0 indicates that Croatia does not have a trade relationship with the country for tomatoes. On the horizontal axis the overall attractiveness of the markets are shows, calculated as the weighted scores on market size (import value 2013-2105), market growth (absolute growth in imports in euros between 2009 and 2015), stability of imports, import market price, and concentration of the market. The bubble sizes show the total import value in the countries. Countries that are located closest to the upper right corner have the highest combined scores for market attractiveness and business position. These are the markets that are most attractive for Croatian growers and exporters to further develop. As our analysis is based on data for the period 2005-2015 because complete trade data for 2016 for all countries in the world was not available yet, in some cases our analysis has been overtaken by reality. The current ban on imports of EU fruit and vegetables in Russia is an example.

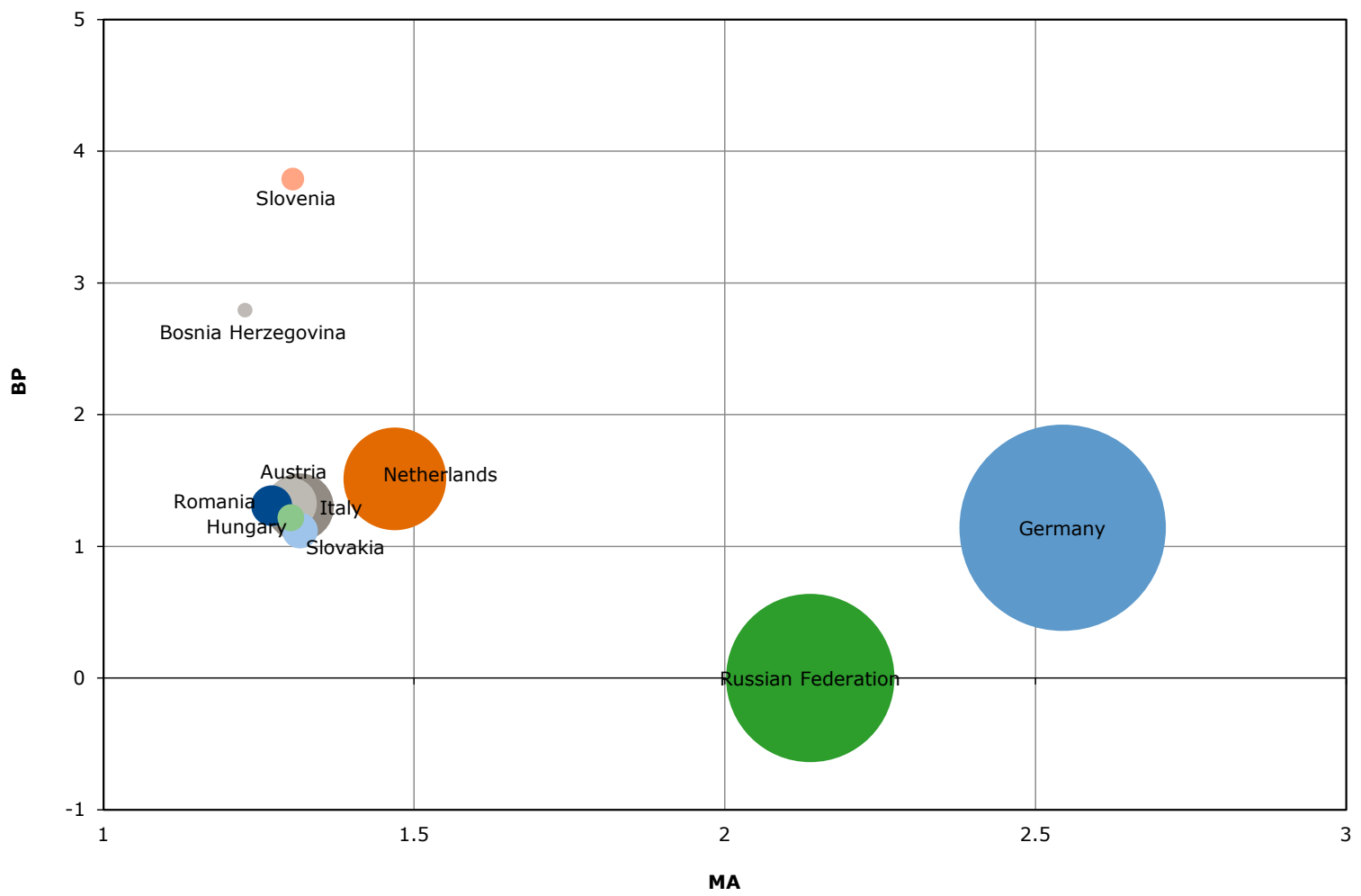

Figure A3.1 Market attractiveness and business position for tomatoes, based on data for 2005-2015 Source: UN Comtrade, calculations Wageningen Economic Research.

Overall, Croatia does not export many tomatoes at all. Slovenia is the only significant export destination for Croatian tomatoes that exceeds $€ 1 \mathrm{~m}$ in the past 3 years. The analysis shows that Germany and Russia are major markets on which Croatia already has a position. However, the business position of Croatia is less than 2, indicating that there is still much to improve in terms of either prices or market shares. In Slovenia and Bosnia Herzegovina, the business position of Croatia is better, but these markets are small. The USA is the most attractive market for tomatoes, according to our analysis, but Croatia does not have a position on this market. We include the USA in the results however, to show its relative attractiveness and size. The USA is the most attractive market even though its combined score is only around 2.7. Many countries do well on one or two indicators, while 
they do worse on other indicators. The USA is a huge market that has been growing, but it is displays a high instability and it is quite concentrated with most imports of tomatoes coming from Mexico.

Germany is the largest import market for tomatoes in Europe. Germany imported almost 1.2 billion euros of tomatoes in 2016. Croatia has been exporting tomatoes to Germany since 2014, although the exported volumes are still small. In 2016, Croatia exported 261 thousand euros of tomatoes to Germany. The prices of tomatoes from Croatia on the German market were somewhat lower than those of the major competitors, like the Netherlands, Spain, Morocco, Italy and France. Also exporters in e.g. Hungary and the Czech Republic persistently get higher prices in the past three years. Of the larger competitors, only tomatoes from Poland and Turkey are paid less or equally low as Croatian tomatoes on the German market. Nevertheless, of all larger import markets considered, Germany seems to be the most attractive market and the one on which Croatia already has a position.

In Russia, after August 2014, imports from EU countries have been banned. Turkey was the largest exporter to Russia until 2015, with some $€ 300 \mathrm{~m}$ worth of trade, but imports from Turkey also stopped in 2016 after a ban was imposed on that country as well after a Russian fighter jet was in show down in Syria in November 2015. Other important exporters to Russia are Morocco ( $€ 149 \mathrm{~m}$ in 2016$)$, China ( $€ 95 \mathrm{~m}$ in 2015), Azerbaijan ( $€ 83 \mathrm{~m}$ in 2015), and Belarus ( $€ 58 \mathrm{~m}$ in 2015). Especially Morocco, Azerbaijan and Belarus are profiting from the import bans on imports from the EU and Turkey. The ban on imports from the EU is scheduled to last until the end of 2018. This could potentially offer new opportunities for EU countries including Croatia after 2018.

Hungary has a relatively high import market price, and is not very much concentrated. Croatia has a small but nevertheless proven position on the Hungarian market and this country may prove to be an interesting stepping stone into the further European market. Besides the ten market windows listed in the chart, there are also some promising countries that Croatia is not yet exporting to. France, the UK, and Belarus are relatively attractive markets for tomatoes. The United Arab Emirates is a fast growing market, although average import prices are low. 


\section{Cabbages}

For cabbages the market attractiveness and business position of Croatia are shown in figure A3.2 below. Like for tomatoes, cabbages are not much exported from Croatia. A total of just $€ 500$ thousand to $€ 700$ thousand of cabbages is exported annually. The position of Croatia is most favourable on nearby markets. Most of the exports from Croatia go to Slovenia, where Croatia has a market share of about 9\%. Exports to other countries, like Romania, Bosnia Herzegovina, Austria and Italy are still very limited. Nevertheless, Romania and Bosnia Herzegovina are importing cabbages from Croatia. Romania's average import prices from the world are relatively low with just 23 eurocents per kilogram. Only Bosnia Herzegovina pays less, with €0.17 per kilogram. It seems however that Croatian cabbages are paid relatively well in these countries, compared to the average import prices.

Canada is the largest importing country of cabbages in the list of selected market windows, with annual imports of about $€ 200 \mathrm{~m}$. Like Kuwait and Switzerland (see Appendix 4), Canada is paying relatively high prices for cabbages. But it is hardly importing anything from the benchmark countries and may therefore be considered a less attractive market for Croatian exporters. Germany may be much more interesting as a destination country for Croatian cabbages. It is the largest European market for cabbages and it is paying relatively high prices per kilogram. The Italian and Austrian markets are scored about the same for Market attractiveness but exports to Austria were below the threshold of $€ 10$ thousand per year and hence Croatia's Business position is not calculated and Austria is not in the top-10 as a market window. The Austrian import market is slightly bigger than het Italian market though, and they have the same growth and stability. Austria is paying higher prices, but it is also a more concentrated market. Both are currently just very small destination countries for cabbages from Croatia and may be interesting markets to develop in the future.

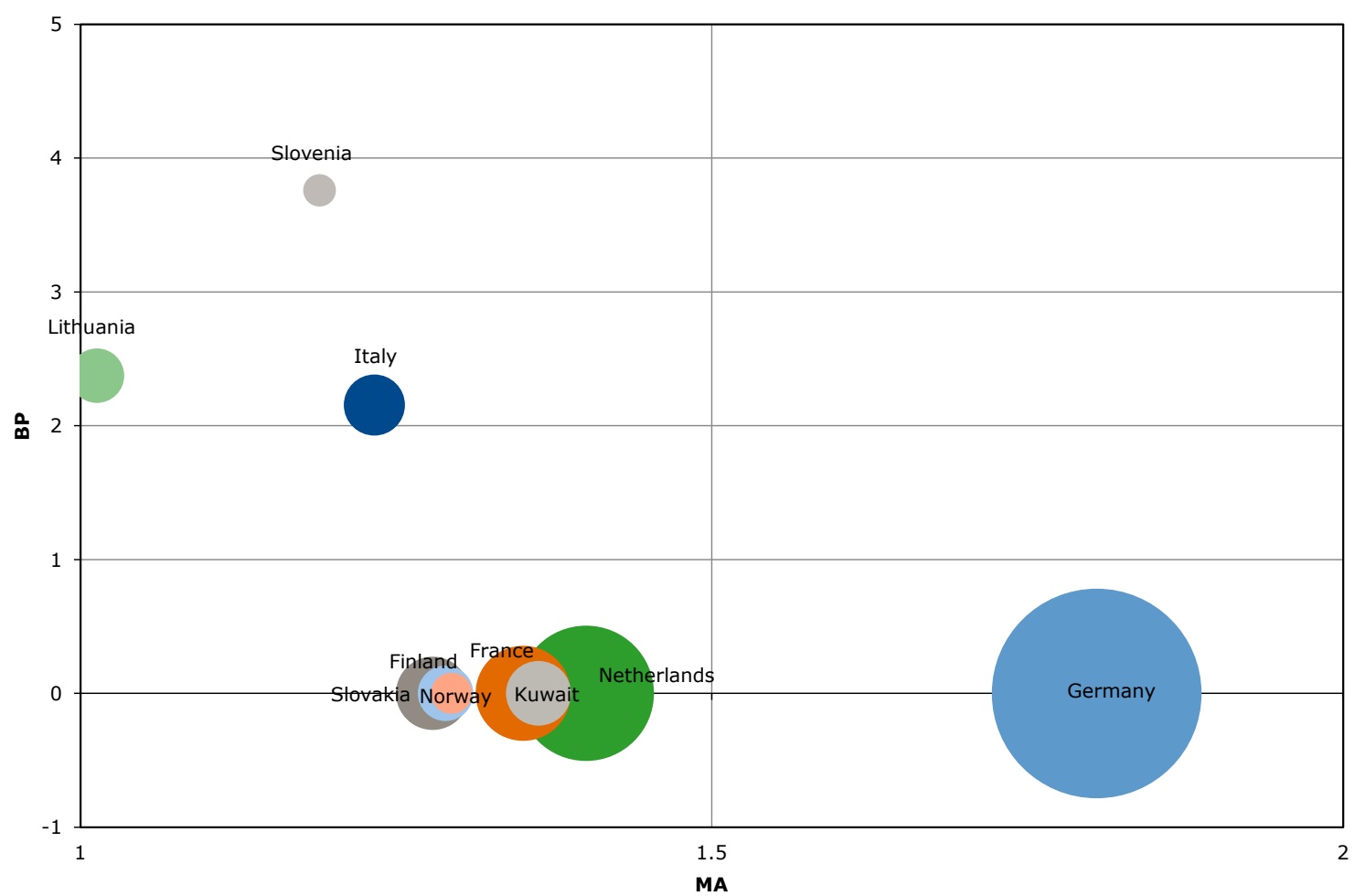

Figure A3.2 Market attractiveness and business position for cabbages, based on data for 2005-2015 Source: UN Comtrade, calculations Wageningen Economic Research. 


\section{Onions}

Croatia is exporting about $€ 300$ thousand to $€ 750$ thousand worth of cabbages in the last 3 years. Exported volumes are fluctuating between 256 and 1404 tonnes between 2012 and 2016, with a peak to 5,022 tonnes in 2015. Bosnia Herzegovina has long been the most important export destination, but has been overtaken by Slovenia and Serbia in recent years. Albania has the highest score on business position, but this is caused by a one-year peak in imports from Croatia, and is excluded from having a score on business position because it is below the $€ 10$ thousand threshold for imports from Croatia. Most cabbages in Albania are imported from Serbia and the Netherlands. In the figure below with the top-10 market windows, Slovenia, Bosnia Herzegovina and Hungary are shown to be the countries with highest business position for Croatia.

Although Serbia is currently the number one destination for Croatian onions, and the fifth ranked market window, it is not in the top-10 with respect to market attractiveness. Croatia is the number 3 supplier to Serbia, after the Netherlands and Macedonia. However, the prices paid for Croatian onions are much lower than average import prices in Serbia. The most interesting markets in terms of size, growth and prices paid are - apart from the USA - the United Kingdom, Germany, and the Netherlands although seasonality would overlap and the Netherlands is a large exporter of onions as well. The United Arab Emirates is an interesting market window in the Middle East (See Appendix 3for more details).

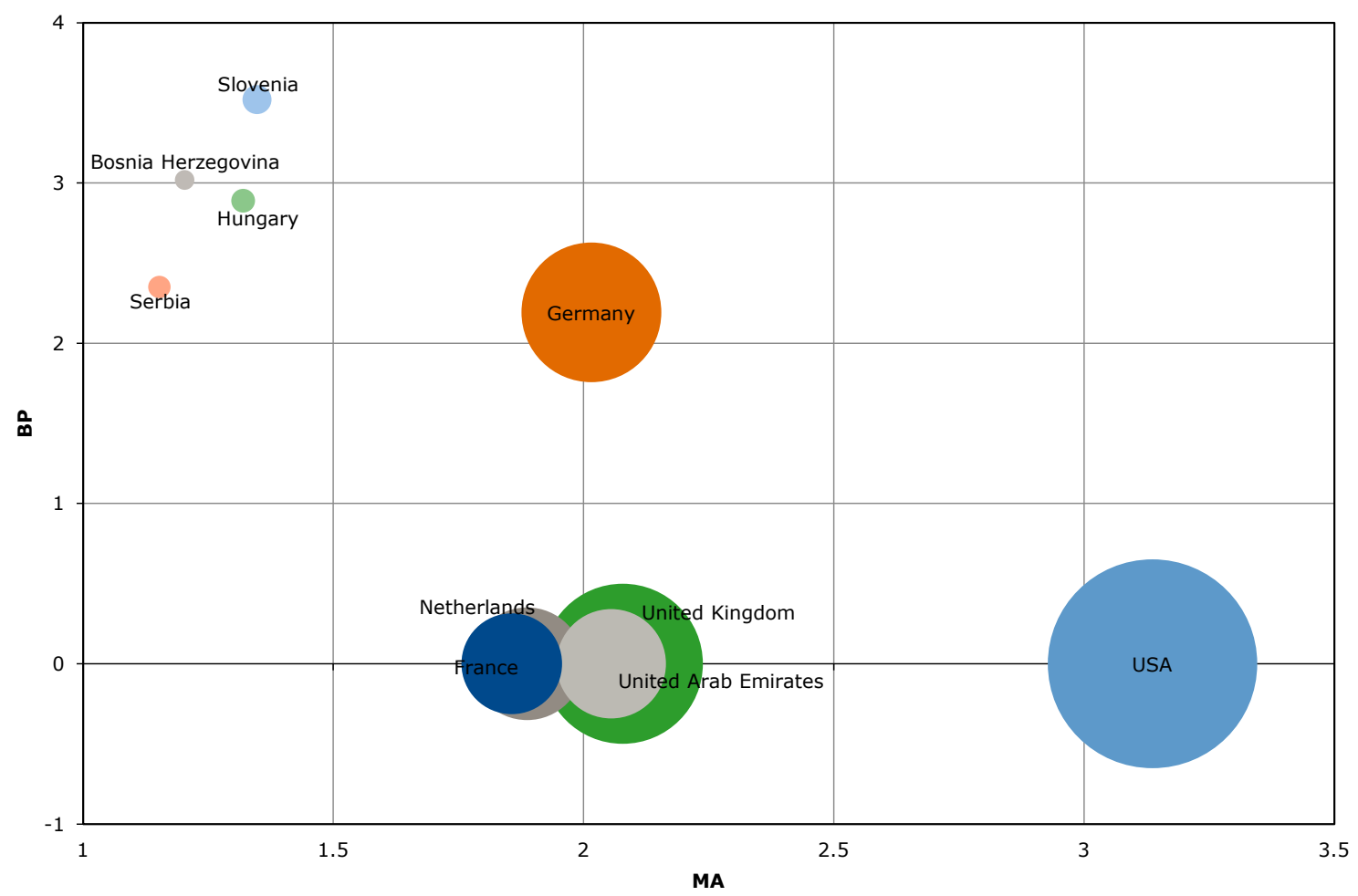

Figure A3.3 Market attractiveness and business position for onions, based on data for 2005-2015 Source: UN Comtrade, calculations Wageningen Economic Research. 


\section{Garlic}

For garlic, the most attractive market is found to be Indonesia. This is due to the inclusion of China as a benchmark country for garlic. Indonesia is almost exclusively supplied from China and does not pay particularly high prices. But because it is a huge market that is growing fast, it is ranking first in terms of market attractiveness. Within Europe, Luxembourg is scoring high because of the relatively high prices paid. The same holds for Sweden and Finland. The United States of America are also an attractive market. Although the USA is also mainly supplied from China, in recent years Spain is also a fast growing supplier to the USA. Business position was only calculated for Slovenia as the other countries do not import sufficient amounts of garlic from Croatia yet.

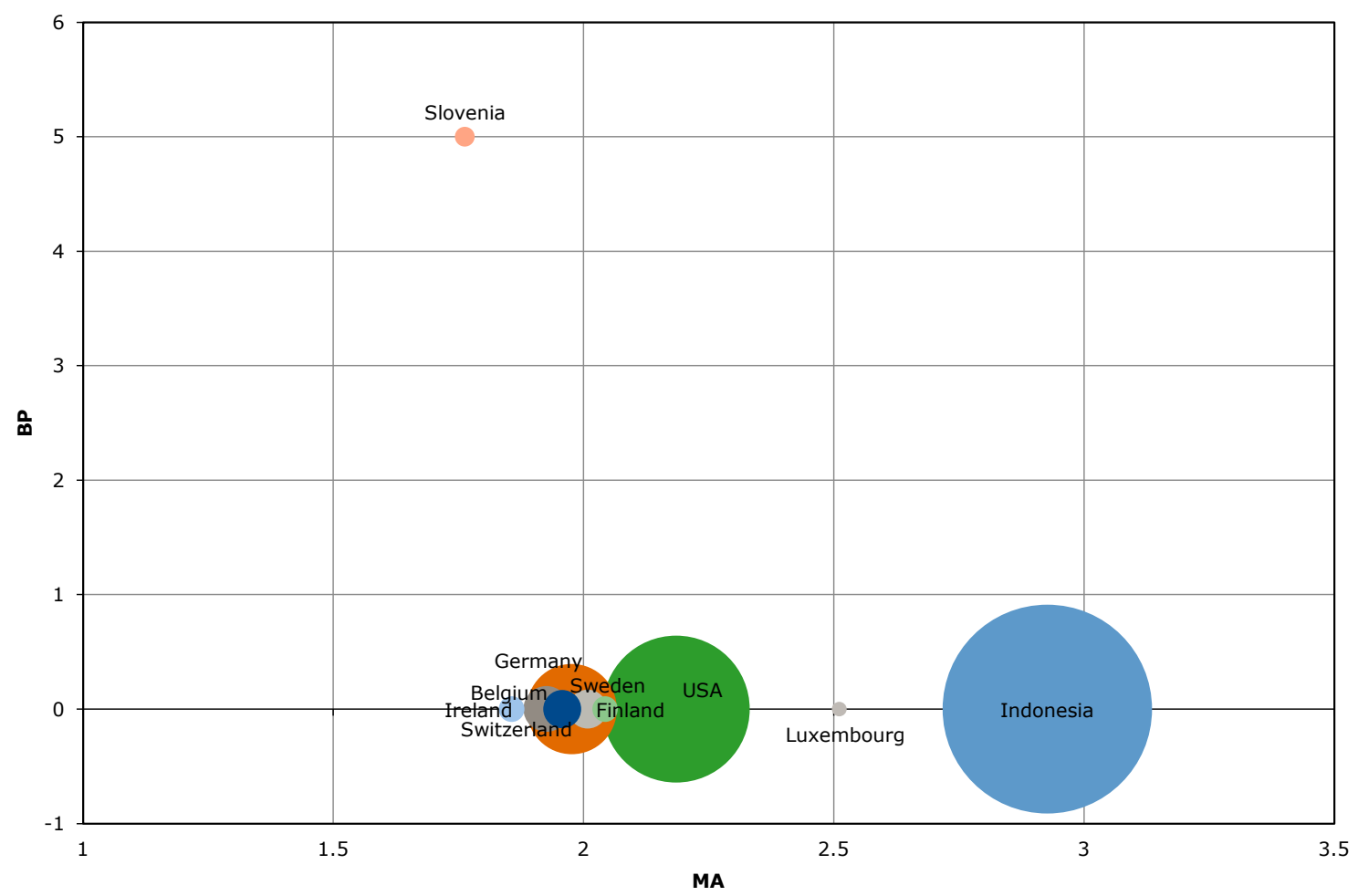

Figure A3.4 Market attractiveness and business position for garlic, based on data for 2005-2015 Source: UN Comtrade, calculations Wageningen Economic Research. 


\section{Apples}

The top-20 market windows for apples show a mix of nearby markets in Serbia, Slovenia and Bosnia Herzegovina, upcoming markets in Russia (currently closed due to an import ban on EU fruit and vegetables) and Belarus, a number of countries in the Middle-East, most notably Egypt and the United Arab Emirates, and some more traditional European markets in the Netherlands, Germany, Italy, the United Kingdom and Spain. Egypt and Austria (just outside the top-10) are the largest export destinations for apples from Croatia, but Egypt pays considerably higher prices and is growing much faster. The data show that Germany, Austria and Italy are still relatively attractive markets, but the position of Croatia is weak. Prices paid for apples from Croatia on these markets are only half or less of that of average import prices. This may explain a shift towards other markets in the Middle-East that generally pay higher prices. The export portfolio of Croatia for apples is much more diversified than for the other products analysed in this report. There are relatively many countries in which Croatia has a relatively high business position.

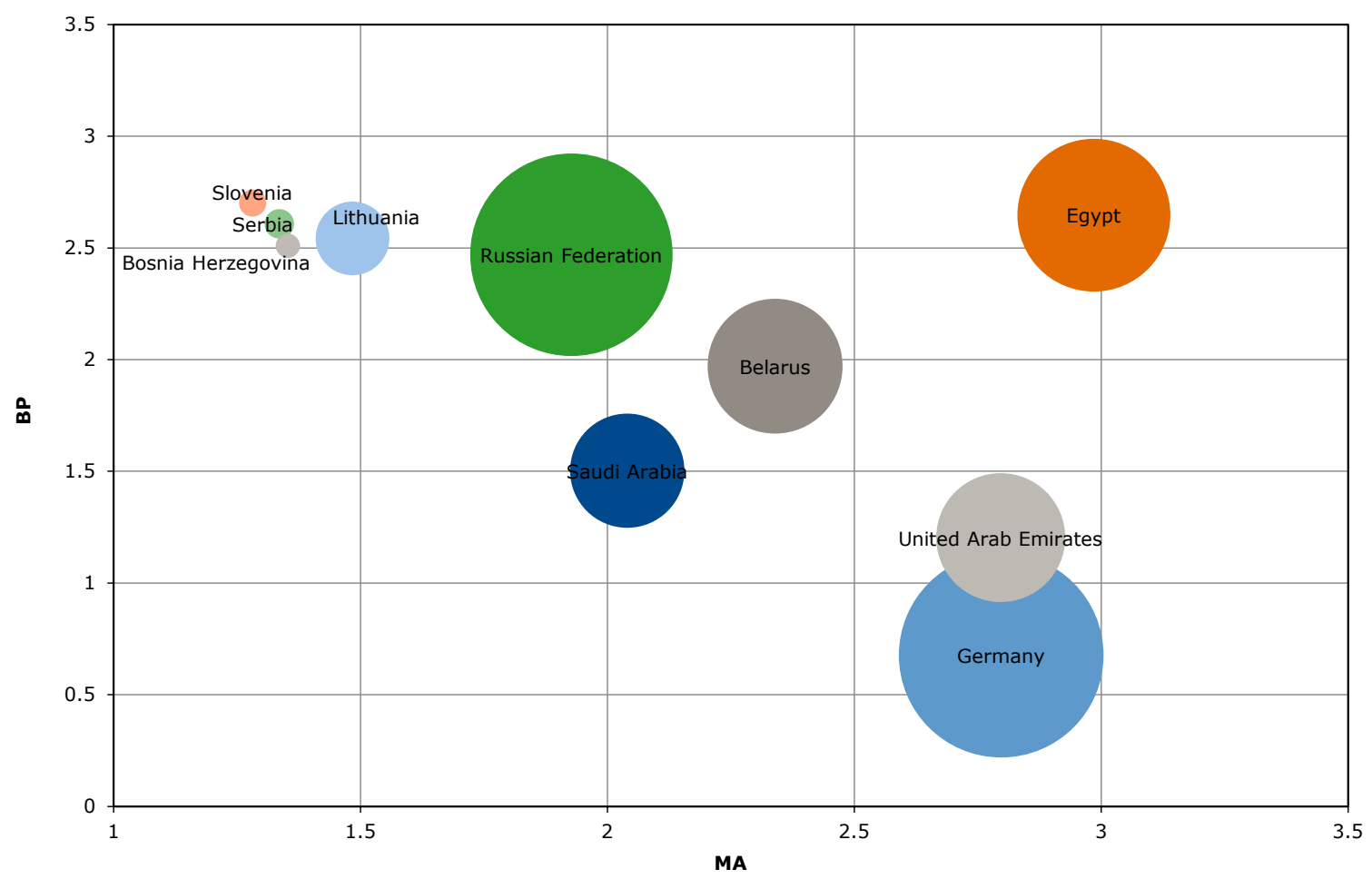

Figure A3.5 Market attractiveness and business position for apples, based on data for 2005-2015 Source: UN Comtrade, calculations Wageningen Economic Research. (note: import data for Egypt is erratic, therefore import prices were estimated by ITC in such a way that import prices for Croatia were equal to average import prices from all countries.) 


\section{Mandarins}

Although exports of mandarins (mainly satsumas) has increased since 2005 from less than 5 to more than $€ 15 \mathrm{~m}$ per year, the growth somewhat stagnated after 2010 . Exports fluctuate considerably between years. Serbia, Slovenia, the Czech Republic and Bosnia Herzegovina are the most important export destinations, followed by Germany and Slovakia. The top-10 market windows in terms of market attractiveness and business position are shown in figure A3.6. Without the import ban on fruit from the EU, the Russian market would have been the most attractive market for Croatia, especially due to its size and market growth. The United Kingdom and France are also attractive markets, which pay relatively high prices. The market position of Croatia on these markets is unfortunately not very strong. The same holds for Germany and the Netherlands. The countries where Croatia has a relatively strong position, are paying lower prices on average and are also not growing as much as some of the other countries. Ukraine and Belarus may be considered interesting markets, that show large growth and pay somewhat higher prices than the traditional export markets for Croatia.

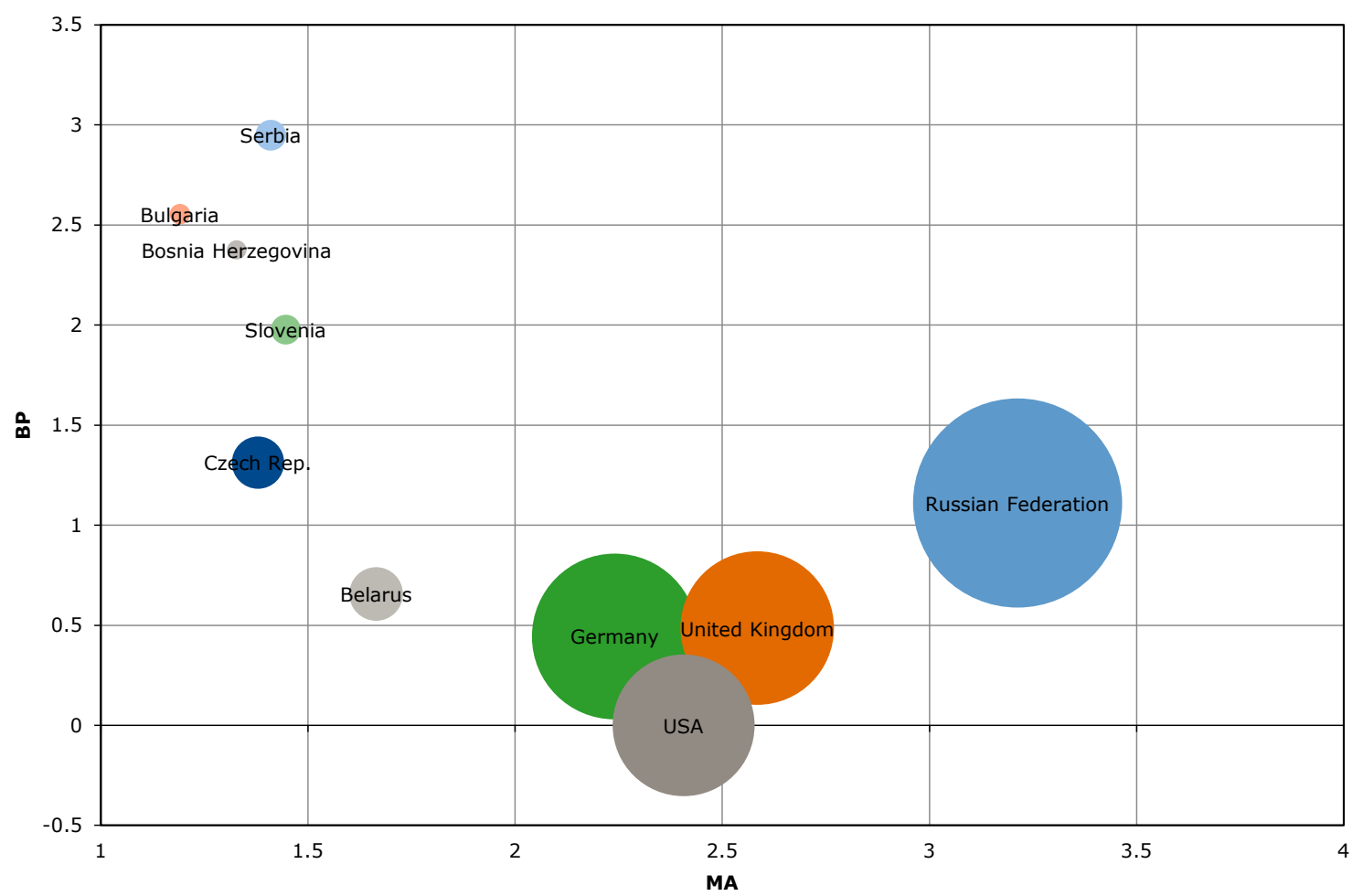

Figure A3.6 Market attractiveness and business position for mandarins, based on data for 2005-2015 Source: UN Comtrade, calculations Wageningen Economic Research. 


\section{Sour cherries}

Exports of cherries are small, but growing. The latest data for 2016 show that about $€ 700$ thousand $(2,270$ tonnes $)$ of sour cherries were exported from Croatia. Because trade data of sour cherries and other cherries were not reported separately before 2012, we use data for both types of cherries for our analysis, which is also limited to the period until 2015 because world trade data for 2016 were not yet complete at the time.

Main export destinations for sour cherries in 2015 were Bosnia Herzegovina, Germany, and Serbia. ${ }^{38}$ It must be noted that with the exception of Germany, these countries exhibit lower than average import prices for cherries. Croatia reported some shipments of sour cherries to Greece, Italy, and Austria in the 2013-2015 period, but these were below the $€ 10$ thousand threshold and hence these potential markets are not scored in terms of business position for Croatia. They might however be interesting markets if exported volumes can be increased in the future. The United Kingdom and the Netherlands are interesting market windows for sour cherries, although Croatia has no position yet on the UK and Dutch market. The same holds for France and Belgium. Malta is in the top-10 due to the relatively high prices paid for imported cherries.

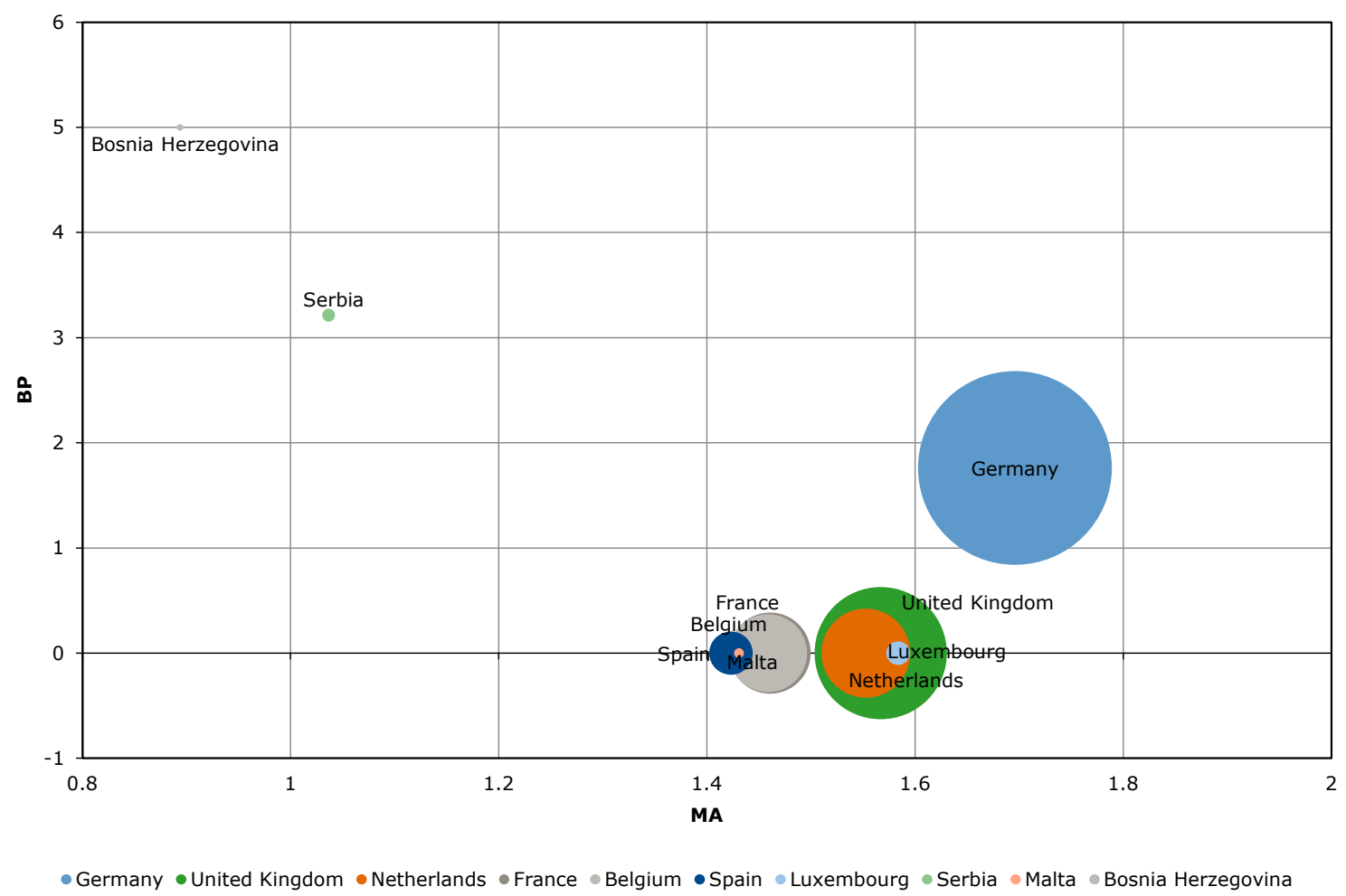

Figure A3.7 Market attractiveness and business position for cherries, based on data for 2005-2015 Source: UN Comtrade, calculations Wageningen Economic Research.

\footnotetext{
${ }^{38}$ Croatia also reports a growing amount of exports of sour cherries to the Czech Republic, of 100 tonnes in 2014 to 461 tonnes in 2016 (Source: UN Comtrade). But the Czech republic does not report these imports from Croatia and we use import data for our analysis.
} 


\section{Appendix 4 Summary of MABA statistics}

Tomatoes, sorted by sum of $M A+B P$

\begin{tabular}{|c|c|c|c|c|c|c|c|c|c|c|c|}
\hline & \multicolumn{6}{|c|}{ Market Attractiveness } & \multicolumn{4}{|c|}{ Business Position } & \multirow{2}{*}{$\begin{array}{l}\text { Import from benchmark } \\
\text { countries and Croatia } \\
\text { C1,000 } \\
\text { avg. } 2013-2015\end{array}$} \\
\hline & $\begin{array}{l}\text { SIZE } \\
\left(C_{1,000)}\right.\end{array}$ & $\begin{array}{l}\text { GROWTH } \\
(€ 1,000)\end{array}$ & $\begin{array}{l}\text { STABILITY } \\
\text { (standard error) }\end{array}$ & $\begin{array}{l}\text { PRICE } \\
\text { (Euro/kg) }\end{array}$ & HHI & Score MA & $\begin{array}{l}\text { SIZE } \\
(€ 1,000)\end{array}$ & Market Share & $\begin{array}{l}\text { PRICE } \\
\text { (relative to world) }\end{array}$ & Score BP & \\
\hline Slovenia & 13,365 & $-1,064$ & 1,680 & 0.97 & 0.15 & 1.30 & 1057 & 0.08 & 0.94 & 3.79 & 1,0280 \\
\hline Bosnia Herzegovina & 5,706 & 868 & 761 & 0.39 & 0.24 & 1.23 & 74 & 0.01 & 1.82 & 2.79 & 4,720 \\
\hline Germany & $1,112,330$ & 174,334 & 41,453 & 1.48 & 0.34 & 2.54 & 60 & 0.00 & 0.78 & 1.14 & $1,005,136$ \\
\hline Netherlands & 275,604 & 35,621 & 24,479 & 1.16 & 0.27 & 1.47 & 14 & 0.00 & 1.09 & 1.51 & 176,205 \\
\hline Austria & 69,297 & 4,973 & 5,180 & 1.45 & 0.28 & 1.30 & 13 & 0.00 & 0.95 & 1.33 & 59,166 \\
\hline Italy & 120,276 & 12,783 & 13,895 & 0.94 & 0.25 & 1.32 & 26 & 0.00 & 0.92 & 1.30 & 82,461 \\
\hline Romania & 43,253 & 8,872 & 13,958 & 0.83 & 0.19 & 1.27 & 23 & 0.00 & 0.93 & 1.31 & 32,604 \\
\hline Hungary & 18,736 & 4,704 & 3,082 & 1.27 & 0.22 & 1.30 & 92 & 0.00 & 0.75 & 1.22 & 10,320 \\
\hline Slovakia & 33,271 & 707 & 4,538 & 1.13 & 0.16 & 1.32 & 13 & 0.00 & 0.80 & 1.12 & 21,352 \\
\hline Russian Federation & 742,545 & 199,576 & 90,945 & 0.94 & 0.24 & 2.14 & 0 & 0.00 & 0.00 & 0.00 & 499,457 \\
\hline Serbia & 13,450 & 718 & 1,604 & 0.56 & 0.32 & 1.18 & 18 & 0.00 & 0.66 & 0.94 & 9,420 \\
\hline Czech Rep. & 93,590 & 5,024 & 7,651 & 0.99 & 0.19 & 1.34 & 59 & 0.00 & 0.48 & 0.74 & 71,942 \\
\hline France & 497,926 & 87,972 & 35,597 & 0.90 & 0.32 & 1.74 & 0 & 0.00 & 0.00 & 0.00 & 431,483 \\
\hline United Kingdom & 529,471 & 40,467 & 39,163 & 1.28 & 0.27 & 1.61 & 0 & 0.00 & 0.00 & 0.00 & 454,166 \\
\hline Belarus & 96,759 & 81,310 & 27,257 & 0.85 & 0.15 & 1.56 & 0 & 0.00 & 0.00 & 0.00 & 44,846 \\
\hline United Arab Emirates & 92,350 & 92,350 & 32,314 & 0.54 & 0.24 & 1.50 & 0 & 0.00 & 0.00 & 0.00 & 16,178 \\
\hline Poland & 149,945 & 42,980 & 9,097 & 1.08 & 0.24 & 1.50 & 0 & 0.00 & 0.00 & 0.00 & 117,897 \\
\hline Belgium & 132,474 & 34,656 & 10,457 & 1.35 & 0.31 & 1.42 & 0 & 0.00 & 0.00 & 0.00 & 84,710 \\
\hline Sweden & 138,884 & 23,124 & 8,899 & 1.52 & 0.38 & 1.35 & 0 & 0.00 & 0.00 & 0.00 & 117,225 \\
\hline Switzerland & 66,208 & 8,143 & 3,507 & 1.76 & 0.27 & 1.34 & 0 & 0.00 & 0.00 & 0.00 & 62,575 \\
\hline
\end{tabular}


Cabbages, sorted by sum of $M A+B P$

\begin{tabular}{|c|c|c|c|c|c|c|c|c|c|c|c|}
\hline & \multicolumn{6}{|c|}{ Market Attractiveness } & \multicolumn{4}{|c|}{ Business Position } & \multirow{2}{*}{$\begin{array}{l}\text { Import from benchmark } \\
\text { countries and Croatia } \\
\text { C1,000, } \\
\text { avg. 2013-2015 }\end{array}$} \\
\hline & $\begin{array}{l}\text { SIZE } \\
(c 1,000)\end{array}$ & $\begin{array}{l}\text { GROWTH } \\
(€ 1,000)\end{array}$ & $\begin{array}{l}\text { STABILITY } \\
\text { (standard error) }\end{array}$ & $\begin{array}{l}\text { PRICE } \\
(C / \mathrm{kg})\end{array}$ & HHI & Score MA & $\begin{array}{l}\text { SIZE } \\
(€ 1,000)\end{array}$ & Market Share & $\begin{array}{l}\text { PRICE } \\
\text { (relative to world) }\end{array}$ & $\begin{array}{l}\text { Score } \\
\text { BP }\end{array}$ & \\
\hline Slovenia & 2,745 & 718 & 348 & 0.47 & 0.23 & 1.19 & 260 & 0.09 & 0.70 & 3.76 & 1,145 \\
\hline Italy & 9,757 & 2,325 & 1,381 & 0.53 & 0.22 & 1.23 & 16 & 0.00 & 1.13 & 2.15 & 4,976 \\
\hline Lithuania & 7,811 & 651 & 5,980 & 0.36 & 0.35 & 1.01 & 36 & 0.00 & 1.18 & 2.37 & 6,908 \\
\hline Germany & 114,888 & 20,354 & 9,882 & 0.83 & 0.30 & 1.80 & 0 & 0.00 & 0.00 & 0.00 & 68,044 \\
\hline Netherlands & 48,060 & 8,674 & 4,001 & 0.63 & 0.33 & 1.40 & 0 & 0.00 & 0.00 & 0.00 & 28,336 \\
\hline Kuwait & 11,037 & 10,958 & 3,929 & 1.56 & 0.21 & 1.36 & 0 & 0.00 & 0.00 & 0.00 & 1,091 \\
\hline France & 23,719 & 3,585 & 1,698 & 0.61 & 0.18 & 1.35 & 0 & 0.00 & 0.00 & 0.00 & 14,615 \\
\hline Norway & 4,377 & 614 & 500 & 1.22 & 0.18 & 1.29 & 0 & 0.00 & 0.00 & 0.00 & 1,759 \\
\hline Finland & 8,003 & 1,836 & 505 & 1.42 & 0.26 & 1.29 & 0 & 0.00 & 0.00 & 0.00 & 4,368 \\
\hline Slovakia & 14,116 & 1,750 & 1,774 & 0.41 & 0.15 & 1.28 & 0 & 0.00 & 0.00 & 0.00 & 4,883 \\
\hline United Kingdom & 34,204 & 892 & 4,882 & 0.77 & 0.30 & 1.26 & 0 & 0.00 & 0.00 & 0.00 & 25,293 \\
\hline Switzerland & 19,971 & 3,751 & 1,163 & 1.36 & 0.43 & 1.25 & 0 & 0.00 & 0.00 & 0.00 & 10,092 \\
\hline Czech Rep. & 17,887 & 1,589 & 2,266 & 0.35 & 0.22 & 1.24 & 0 & 0.00 & 0.00 & 0.00 & 8,733 \\
\hline Belgium & 17,200 & 2,353 & 1,797 & 0.87 & 0.33 & 1.23 & 0 & 0.00 & 0.00 & 0.00 & 13,642 \\
\hline Belarus & 18,472 & 13,607 & 5,728 & 0.37 & 0.33 & 1.21 & 0 & 0.00 & 0.00 & 0.00 & 13,842 \\
\hline Austria & 13,689 & 3,175 & 1,030 & 0.80 & 0.36 & 1.21 & 0 & 0.00 & 0.00 & 0.00 & 3,130 \\
\hline Romania & 3,878 & 1,841 & 863 & 0.23 & 0.18 & 1.20 & 0 & 0.00 & 0.00 & 0.00 & 2,031 \\
\hline Russian Federation & 68,448 & $-2,282$ & 16,102 & 0.36 & 0.23 & 1.20 & 0 & 0.00 & 0.00 & 0.00 & 23,154 \\
\hline Poland & 7,072 & 607 & 2,111 & 0.44 & 0.20 & 1.19 & 0 & 0.00 & 0.00 & 0.00 & 3,108 \\
\hline Croatia & 2,303 & 1,106 & 476 & 0.36 & 0.21 & 1.19 & 0 & 0.00 & 0.00 & 0.00 & 1,644 \\
\hline
\end{tabular}


Onions, sorted by sum of $M A+B P$

\begin{tabular}{|c|c|c|c|c|c|c|c|c|c|c|c|}
\hline & \multicolumn{6}{|c|}{ Market Attractiveness } & \multicolumn{4}{|c|}{ Business Position } & \multirow{2}{*}{$\begin{array}{l}\text { Import from benchmark } \\
\text { countries and Croatia } \\
\text { C1,000, } \\
\text { avg. 2013-2015 }\end{array}$} \\
\hline & $\begin{array}{l}\text { SIZE } \\
(€ 1,000)\end{array}$ & $\begin{array}{l}\text { GROWTH } \\
(€ 1,000)\end{array}$ & $\begin{array}{l}\text { STABILITY } \\
\text { (standard error) }\end{array}$ & $\begin{array}{l}\text { PRICE } \\
(\mathcal{C} / \mathbf{k g})\end{array}$ & HHI & Score MA & $\begin{array}{l}\text { SIZE } \\
(€ 1,000)\end{array}$ & $\begin{array}{l}\text { Market } \\
\text { Share }\end{array}$ & $\begin{array}{l}\text { PRICE } \\
\text { (relative to world) }\end{array}$ & $\begin{array}{l}\text { Score } \\
\text { BP }\end{array}$ & \\
\hline Slovenia & 6,118 & 534 & 1,025 & 0.41 & 0.24 & 1.35 & 71 & 0.01 & 0.92 & 3.52 & 4,423 \\
\hline Bosnia Herzegovina & 2,816 & 722 & 309 & 0.34 & 0.44 & 1.20 & 57 & 0.02 & 0.71 & 3.02 & 2,367 \\
\hline Germany & 141,496 & 24,054 & 15,831 & 0.55 & 0.19 & 2.02 & 38 & 0.00 & 0.68 & 2.19 & 92,625 \\
\hline Hungary & 4,130 & -403 & 1,156 & 0.36 & 0.23 & 1.32 & 26 & 0.01 & 0.98 & 2.89 & 3,220 \\
\hline Serbia & 3,639 & 1,258 & 834 & 0.40 & 0.55 & 1.15 & 80 & 0.02 & 0.28 & 2.35 & 3,030 \\
\hline USA & 317,654 & 116,917 & 42,649 & 0.67 & 0.51 & 3.14 & 0 & 0.00 & 0.00 & 0.00 & 5,829 \\
\hline United Kingdom & 186,459 & 27,033 & 24,453 & 0.46 & 0.20 & 2.08 & 0 & 0.00 & 0.00 & 0.00 & 131,552 \\
\hline United Arab Emirates & 86,745 & 86,745 & 31,424 & 0.26 & 0.31 & 2.06 & 0 & 0.00 & 0.00 & 0.00 & 14,939 \\
\hline Netherlands & 92,191 & 23,815 & 10,587 & 0.42 & 0.11 & 1.89 & 0 & 0.00 & 0.00 & 0.00 & 36,361 \\
\hline France & 73,534 & 23,252 & 8,989 & 0.54 & 0.13 & 1.86 & 0 & 0.00 & 0.00 & 0.00 & 36,273 \\
\hline Malaysia & 153,396 & 28,127 & 24,228 & 0.33 & 0.32 & 1.85 & 0 & 0.00 & 0.00 & 0.00 & 16,011 \\
\hline Canada & 114,887 & 25,031 & 11,690 & 0.63 & 0.51 & 1.79 & 0 & 0.00 & 0.00 & 0.00 & 1,177 \\
\hline Switzerland & 5,532 & 246 & 1,004 & 1.58 & 0.28 & 1.71 & 0 & 0.00 & 0.00 & 0.00 & 1,067 \\
\hline Sierra Leone & 2,275 & 2,275 & 1,879 & 1.42 & 0.24 & 1.67 & 0 & 0.00 & 0.00 & 0.00 & 2,062 \\
\hline Belgium & 67,143 & 11,911 & 7,925 & 0.50 & 0.30 & 1.61 & 0 & 0.00 & 0.00 & 0.00 & 41,316 \\
\hline Singapore & 29,145 & 10,385 & 2,604 & 0.43 & 0.18 & 1.56 & 0 & 0.00 & 0.00 & 0.00 & 2,243 \\
\hline Denmark & 9,900 & -148 & 1,900 & 1.02 & 0.25 & 1.54 & 0 & 0.00 & 0.00 & 0.00 & 7,184 \\
\hline Norway & 6,914 & 1,840 & 1,106 & 0.70 & 0.18 & 1.50 & 0 & 0.00 & 0.00 & 0.00 & 3,242 \\
\hline Ireland & 23,988 & 2,912 & 3,564 & 0.59 & 0.23 & 1.47 & 0 & 0.00 & 0.00 & 0.00 & 14,370 \\
\hline Italy & 30,944 & 3,048 & 5,574 & 0.40 & 0.16 & 1.46 & 0 & 0.00 & 0.00 & 0.00 & 18,056 \\
\hline
\end{tabular}


Garlic, sorted by sum of MA + BP

\begin{tabular}{|c|c|c|c|c|c|c|c|c|c|c|c|}
\hline & \multicolumn{6}{|c|}{ Market Attractiveness } & \multicolumn{4}{|c|}{ Business Position } & \multirow{2}{*}{$\begin{array}{l}\text { Import from benchmark } \\
\text { countries and Croatia } \\
\text { C1,000, } \\
\text { avg. 2013-2015 }\end{array}$} \\
\hline & $\begin{array}{l}\text { SIZE } \\
(€ 1,000)\end{array}$ & $\begin{array}{l}\text { GROWTH } \\
(€ 1,000)\end{array}$ & $\begin{array}{l}\text { STABILITY } \\
\text { (standard error) }\end{array}$ & $\begin{array}{l}\text { PRICE } \\
(C / \mathrm{kg})\end{array}$ & HHI & $\begin{array}{l}\text { Score } \\
\text { MA }\end{array}$ & $\begin{array}{l}\text { SIZE } \\
(€ 1,000)\end{array}$ & Market Share & $\begin{array}{l}\text { PRICE } \\
\text { (relative to world) }\end{array}$ & $\begin{array}{l}\text { Score } \\
\text { BP }\end{array}$ & \\
\hline Slovenia & 2,513 & -677 & 543 & 1.99 & 0.23 & 1.76 & 164 & 0.07 & 0.73 & 5.00 & 2,166 \\
\hline Indonesia & 281,235 & 114,313 & 19,525 & 0.60 & 1.00 & 2.93 & 0 & 0.00 & 0.00 & 0.00 & 280,828 \\
\hline Luxembourg & 1,383 & 41 & 98 & 4.83 & 0.17 & 2.51 & 0 & 0.00 & 0.00 & 0.00 & 982 \\
\hline USA & 139,104 & 58,765 & 21,954 & 1.73 & 0.71 & 2.18 & 0 & 0.00 & 0.00 & 0.00 & 129,385 \\
\hline Finland & 4,222 & 1,012 & 213 & 3.18 & 0.30 & 2.04 & 0 & 0.00 & 0.00 & 0.00 & 2,296 \\
\hline Sweden & 9,795 & 1,240 & 849 & 3.07 & 0.34 & 2.01 & 0 & 0.00 & 0.00 & 0.00 & 4,796 \\
\hline Germany & 52,159 & 1,456 & 6,994 & 2.49 & 0.29 & 1.98 & 0 & 0.00 & 0.00 & 0.00 & 42,521 \\
\hline Switzerland & 9,251 & -607 & 979 & 2.90 & 0.32 & 1.96 & 0 & 0.00 & 0.00 & 0.00 & 8,487 \\
\hline Belgium & 13,485 & 4,203 & 1,426 & 2.41 & 0.26 & 1.93 & 0 & 0.00 & 0.00 & 0.00 & 8,451 \\
\hline Ireland & 4,278 & 775 & 455 & 2.22 & 0.21 & 1.86 & 0 & 0.00 & 0.00 & 0.00 & 1,955 \\
\hline Denmark & 4,811 & 699 & 532 & 2.14 & 0.24 & 1.82 & 0 & 0.00 & 0.00 & 0.00 & 3,121 \\
\hline Austria & 9,709 & $-2,344$ & 1,996 & 2.19 & 0.26 & 1.79 & 0 & 0.00 & 0.00 & 0.00 & 8,709 \\
\hline France & 53,311 & 2,065 & 7,528 & 1.79 & 0.35 & 1.77 & 0 & 0.00 & 0.00 & 0.00 & 47,001 \\
\hline Slovakia & 3,801 & $-1,059$ & 845 & 2.02 & 0.26 & 1.75 & 0 & 0.00 & 0.00 & 0.00 & 2,683 \\
\hline Malta & 487 & -146 & 142 & 2.20 & 0.40 & 1.71 & 0 & 0.00 & 0.00 & 0.00 & 188 \\
\hline United Kingdom & 39,813 & 5,488 & 5,714 & 1.59 & 0.42 & 1.68 & 0 & 0.00 & 0.00 & 0.00 & 33,479 \\
\hline Estonia & 555 & -332 & 214 & 1.82 & 0.31 & 1.68 & 0 & 0.00 & 0.00 & 0.00 & 390 \\
\hline Canada & 28,159 & 7,409 & 3,953 & 1.58 & 0.42 & 1.67 & 0 & 0.00 & 0.00 & 0.00 & 19,787 \\
\hline Croatia & 2,198 & -424 & 661 & 1.41 & 0.19 & 1.64 & 0 & 0.00 & 0.00 & 0.00 & 1,670 \\
\hline Poland & 8,313 & $-1,431$ & 1945 & 1.50 & 0.26 & 1.62 & 0 & 0.00 & 0.00 & 0.00 & 3,375 \\
\hline
\end{tabular}


Apples, sorted by sum of $M A+B P$

\begin{tabular}{|c|c|c|c|c|c|c|c|c|c|c|c|}
\hline & \multicolumn{6}{|c|}{ Market Attractiveness } & \multicolumn{4}{|c|}{ Business Position } & \multirow{2}{*}{$\begin{array}{l}\text { Import from benchmark } \\
\text { countries and Croatia } \\
\text { C1,000, } \\
\text { avg. 2013-2015 }\end{array}$} \\
\hline & $\begin{array}{l}\text { SIZE } \\
(€ 1,000)\end{array}$ & $\begin{array}{l}\text { GROWTH } \\
(€ 1,000)\end{array}$ & $\begin{array}{l}\text { STABILITY } \\
\text { (standard error) }\end{array}$ & $\begin{array}{l}\text { PRICE } \\
(c / k g)\end{array}$ & HHI & $\begin{array}{l}\text { Score } \\
\text { MA }\end{array}$ & $\begin{array}{l}\text { SIZE } \\
(€ 1,000)\end{array}$ & $\begin{array}{l}\text { Market } \\
\text { Share }\end{array}$ & $\begin{array}{l}\text { PRICE } \\
\text { (relative to world) }\end{array}$ & $\begin{array}{l}\text { Score } \\
\text { BP }\end{array}$ & \\
\hline Egypt & 267,718 & 194,824 & 58,485 & 0.93 & 0.23 & 2.98 & 1673 & 0.01 & n.a. $*$ & 2.65 & 127,111 \\
\hline Russian Federation & 469,494 & $-10,061$ & 103,418 & 0.43 & 0.18 & 1.93 & 176 & 0.00 & 1.77 & 2.47 & 185,540 \\
\hline Belarus & 208,176 & 183,486 & 86,358 & 0.47 & 0.42 & 2.34 & 41 & 0.00 & 1.47 & 1.97 & 88,078 \\
\hline Lithuania & 61,810 & 31,000 & 27,693 & 0.31 & 0.25 & 1.48 & 45 & 0.00 & 1.89 & 2.54 & 39,372 \\
\hline United Arab Emirates & 190,507 & 190,507 & 62,071 & 0.91 & 0.12 & 2.80 & 112 & 0.00 & 0.84 & 1.20 & 46,658 \\
\hline Slovenia & 8,523 & 918 & 2,161 & 0.19 & 0.26 & 1.28 & 873 & 0.10 & 0.61 & 2.70 & 6,998 \\
\hline Serbia & 9,826 & 4,213 & 2,893 & 0.27 & 0.24 & 1.34 & 564 & 0.06 & 1.13 & 2.61 & 5,939 \\
\hline Bosnia Herzegovina & 6,677 & 2,131 & 1,343 & 0.25 & 0.18 & 1.35 & 564 & 0.08 & 0.80 & 2.51 & 5,532 \\
\hline Saudi Arabia & 149,428 & 58,298 & 30,053 & 0.78 & 0.18 & 2.04 & 193 & 0.00 & 1.02 & 1.50 & 57,601 \\
\hline Germany & 479,193 & 57,842 & 41,952 & 0.71 & 0.19 & 2.80 & 448 & 0.00 & 0.25 & 0.68 & 295,171 \\
\hline Austria & 28,671 & 5,657 & 7,094 & 0.29 & 0.13 & 1.44 & 1,179 & 0.04 & 0.45 & 1.98 & 15,309 \\
\hline Italy & 24,013 & 440 & 5,142 & 0.55 & 0.10 & 1.51 & 688 & 0.03 & 0.52 & 1.55 & 8,247 \\
\hline United Kingdom & 436,709 & 62,380 & 39,764 & 0.97 & 0.10 & 2.86 & 0 & 0.00 & 0.00 & 0.00 & 175,080 \\
\hline Bulgaria & 8,072 & 1,985 & 1,802 & 0.23 & 0.27 & 1.29 & 19 & 0.00 & 1.11 & 1.50 & 4,144 \\
\hline Norway & 58,596 & 7,141 & 3,818 & 1.17 & 0.31 & 1.70 & 11 & 0.00 & 0.68 & 0.91 & 39,470 \\
\hline Hungary & 6,879 & $-3,680$ & 6,586 & 0.25 & 0.17 & 1.30 & 153 & 0.02 & 0.56 & 1.12 & 4,007 \\
\hline India & 174,972 & 80,212 & 12,716 & 0.89 & 0.30 & 2.30 & 0 & 0.00 & 0.00 & 0.00 & 5,525 \\
\hline Netherlands & 270,964 & 38,895 & 41,382 & 0.66 & 0.10 & 2.19 & 0 & 0.00 & 0.00 & 0.00 & 74,239 \\
\hline Romania & 26,549 & 12,399 & 5,225 & 0.35 & 0.28 & 1.41 & 53 & 0.00 & 0.52 & 0.75 & 22,454 \\
\hline Thailand & 159,058 & 71,890 & 18,323 & 1.10 & 0.47 & 2.13 & 0 & 0.00 & 0.00 & 0.00 & 4,764 \\
\hline
\end{tabular}

(*) 2013 and 2014 trade data excluded for Egypt. 2015 data is estimated by ITC at $€ 0.931$ per kilogram for world and for Croatia alike. 
Mandarins, sorted by sum of $M A+B P$

\begin{tabular}{|c|c|c|c|c|c|c|c|c|c|c|c|}
\hline & \multicolumn{6}{|c|}{ Market Attractiveness } & \multicolumn{4}{|c|}{ Business Position } & \multirow{2}{*}{$\begin{array}{l}\text { Import from benchmark } \\
\text { countries) } \\
\text { (C1,000, } \\
\text { avg. 2013-2015 }\end{array}$} \\
\hline & $\begin{array}{l}\text { SIZE } \\
(€ 1,000)\end{array}$ & $\begin{array}{l}\text { GROWTH } \\
(\varepsilon 1,000)\end{array}$ & $\begin{array}{l}\text { STABILITY } \\
\text { (standard error) }\end{array}$ & $\begin{array}{l}\text { PRICE } \\
(\lessdot / \mathrm{kg})\end{array}$ & HHI & Score MA & $\begin{array}{l}\text { SIZE } \\
(\mathcal{C} 1,000)\end{array}$ & Market Share & $\begin{array}{l}\text { PRICE } \\
\text { (relative to world) }\end{array}$ & $\begin{array}{l}\text { Score } \\
\text { BP }\end{array}$ & \\
\hline Serbia & 12,210 & $-1,230$ & 2,298 & 0.54 & 0.27 & 1.41 & 3,813 & 0.31 & 0.94 & 2.95 & 11,880 \\
\hline Russian Federation & 570,153 & 149,185 & 57,530 & 0.70 & 0.18 & 3.21 & 1,093 & 0.00 & 1.16 & 1.11 & 335,604 \\
\hline Bulgaria & 5,482 & 120 & 655 & 0.27 & 0.52 & 1.19 & 55 & 0.01 & 3.89 & 2.55 & 4,994 \\
\hline Bosnia Herzegovina & 4,936 & -186 & 426 & 0.30 & 0.31 & 1.33 & 1,761 & 0.36 & 0.85 & 2.38 & 4,927 \\
\hline Slovenia & 11,383 & $-1,384$ & 1,465 & 0.66 & 0.27 & 1.45 & 2,206 & 0.19 & 0.89 & 1.98 & 10,018 \\
\hline United Kingdom & 307,471 & 79,322 & 23,694 & 1.04 & 0.20 & 2.58 & 187 & 0.00 & 0.66 & 0.49 & 184,977 \\
\hline Czech Rep. & 35,796 & 1,241 & 2,323 & 0.66 & 0.48 & 1.38 & 1,835 & 0.05 & 0.83 & 1.31 & 30,078 \\
\hline Germany & 358,043 & 53,524 & 13,011 & 0.93 & 0.77 & 2.24 & 65 & 0.00 & 0.66 & 0.44 & 335,544 \\
\hline USA & 262,012 & 88,862 & 45,927 & 1.42 & 0.22 & 2.41 & 0 & 0.00 & 0.00 & 0.00 & 115,042 \\
\hline Belarus & 37,502 & 14,588 & 4,073 & 0.77 & 0.20 & 1.66 & 297 & 0.01 & 0.82 & 0.66 & 25,120 \\
\hline Romania & 23,318 & 10,062 & 2,314 & 0.43 & 0.28 & 1.48 & 62 & 0.00 & 1.26 & 0.84 & 20,644 \\
\hline France & 350,839 & 41,293 & 11,265 & 1.01 & 0.61 & 2.28 & 0 & 0.00 & 0.00 & 0.00 & 302,249 \\
\hline Slovakia & 19,634 & 822 & 1,631 & 0.72 & 0.32 & 1.47 & 606 & 0.03 & 0.78 & 0.81 & 14,761 \\
\hline Ukraine & 120,095 & 41,810 & 26,879 & 0.74 & 0.33 & 1.71 & 50 & 0.00 & 0.78 & 0.52 & 98,014 \\
\hline Netherlands & 188,257 & 33,091 & 5,986 & 0.96 & 0.16 & 2.18 & 0 & 0.00 & 0.00 & 0.00 & 102,090 \\
\hline TFYR of Macedonia & 4,282 & 526 & 396 & 0.48 & 0.46 & 1.29 & 258 & 0.06 & 0.89 & 0.87 & 4,192 \\
\hline Canada & 151,505 & 30,933 & 12,539 & 1.14 & 0.16 & 2.07 & 0 & 0.00 & 0.00 & 0.00 & 68,676 \\
\hline Poland & 99,387 & -7426 & 10,747 & 0.68 & 0.55 & 1.33 & 24 & 0.00 & 0.98 & 0.64 & 85,451 \\
\hline Austria & 41,461 & 6,878 & 1,956 & 1.02 & 0.50 & 1.53 & 116 & 0.00 & 0.54 & 0.39 & 37,693 \\
\hline Lithuania & 34,179 & 2,002 & 6,825 & 0.76 & 0.30 & 1.47 & 30 & 0.00 & 0.65 & 0.43 & 19,911 \\
\hline
\end{tabular}


Cherries, sorted by sum of $M A+B P$

\begin{tabular}{|c|c|c|c|c|c|c|c|c|c|c|c|}
\hline & \multicolumn{6}{|c|}{ Market Attractiveness } & \multicolumn{4}{|c|}{ Business Position } & \multirow{2}{*}{$\begin{array}{l}\text { Import from benchmark } \\
\text { countries and Croatia } \\
\text { c1,000, } \\
\text { avg. 2013-2015 }\end{array}$} \\
\hline & $\begin{array}{l}\text { SIZE } \\
(€ 1,000)\end{array}$ & $\begin{array}{l}\text { GROWTH } \\
(€ 1,000)\end{array}$ & $\begin{array}{l}\text { STABILITY } \\
\text { (standard error) }\end{array}$ & $\begin{array}{l}\text { PRICE } \\
(\varepsilon / \mathbf{k g})\end{array}$ & HHI & $\begin{array}{l}\text { Score } \\
\text { MA }\end{array}$ & $\begin{array}{l}\text { SIZE } \\
(\mathcal{C} 1,000)\end{array}$ & Market Share & $\begin{array}{l}\text { PRICE } \\
\text { (relative to world) }\end{array}$ & $\begin{array}{l}\text { Score } \\
\text { BP }\end{array}$ & \\
\hline Bosnia Herzegovina & 145 & -250 & 240 & 0.30 & 0.74 & 0.89 & 60 & 0.41 & 0.74 & 5.00 & 125 \\
\hline Serbia & 521 & 484 & 241 & 0.64 & 0.56 & 1.04 & 35 & 0.07 & 0.68 & 3.21 & 212 \\
\hline Germany & 118,072 & 36,743 & 19,389 & 1.84 & 0.23 & 1.70 & 36 & 0.00 & 0.30 & 1.76 & 32,290 \\
\hline Luxembourg & 1,752 & -14 & 158 & 4.55 & 0.18 & 1.58 & 0 & 0.00 & 0.00 & 0.00 & 62 \\
\hline United Kingdom & 54,786 & 2,664 & 6,927 & 3.07 & 0.22 & 1.57 & 0 & 0.00 & 0.00 & 0.00 & 239 \\
\hline Netherlands & 24,733 & -161 & 2,036 & 2.96 & 0.12 & 1.55 & 0 & 0.00 & 0.00 & 0.00 & 777 \\
\hline France & 20,771 & 5,142 & 3,129 & 2.79 & 0.25 & 1.46 & 0 & 0.00 & 0.00 & 0.00 & 602 \\
\hline Belgium & 19,102 & 622 & 3,929 & 2.66 & 0.19 & 1.46 & 0 & 0.00 & 0.00 & 0.00 & 1,849 \\
\hline Malta & 300 & 15 & 36 & 4.43 & 0.41 & 1.43 & 0 & 0.00 & 0.00 & 0.00 & 145 \\
\hline Spain & 5,914 & $-4,434$ & 2,079 & 4.43 & 0.40 & 1.42 & 0 & 0.00 & 0.00 & 0.00 & 98 \\
\hline Denmark & 7,162 & 1,553 & 493 & 3.20 & 0.30 & 1.42 & 0 & 0.00 & 0.00 & 0.00 & 340 \\
\hline Switzerland & 11,071 & 4,903 & 2,136 & 3.10 & 0.31 & 1.42 & 0 & 0.00 & 0.00 & 0.00 & 5,589 \\
\hline Latvia & 2,270 & 821 & 482 & 2.27 & 0.17 & 1.41 & 0 & 0.00 & 0.00 & 0.00 & 477 \\
\hline Russian Federation & 84,172 & $-18,825$ & 21,221 & 1.12 & 0.17 & 1.37 & 0 & 0.00 & 0.00 & 0.00 & 17,565 \\
\hline Belarus & 25,156 & 23,479 & 13,783 & 1.18 & 0.22 & 1.35 & 0 & 0.00 & 0.00 & 0.00 & 5,493 \\
\hline Czech Rep. & 898 & 416 & 162 & 1.49 & 0.16 & 1.35 & 0 & 0.00 & 0.00 & 0.00 & 226 \\
\hline Italy & 20,487 & $-3,387$ & 2,780 & 2.12 & 0.30 & 1.35 & 0 & 0.00 & 0.00 & 0.00 & 165 \\
\hline Austria & 23,792 & 14,835 & 4,361 & 2.22 & 0.42 & 1.34 & 0 & 0.00 & 0.00 & 0.00 & 5,462 \\
\hline Slovenia & 1,131 & 26 & 235 & 2.69 & 0.36 & 1.32 & 0 & 0.00 & 0.00 & 0.00 & 630 \\
\hline Lithuania & 10,147 & 5,697 & 5,180 & 1.16 & 0.24 & 1.29 & 0 & 0.00 & 0.00 & 0.00 & 3,689 \\
\hline
\end{tabular}

Minimum import from benchmark countries set at 40 thousand euros for cherries. 


\section{Appendix 5 List of interviewees}

Table A5.1 List of interviewees

\begin{tabular}{|c|c|c|c|c|c|c|c|c|c|c|c|c|c|c|c|c|}
\hline Region & Company/organisation & 정 & 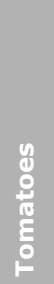 & $\begin{array}{l}0 \\
07 \\
08 \\
00 \\
0 \\
0\end{array}$ & 늘 & $\frac{u}{\frac{2}{2}}$ & $\frac{\frac{y}{2}}{\frac{2}{2}}$ & 들 & $\frac{9}{\frac{1}{2}}$ & $\begin{array}{l}2 \\
\frac{2}{2} \\
\frac{2}{3} \\
\frac{1}{0} \\
\frac{1}{2} \\
\frac{1}{4}\end{array}$ & 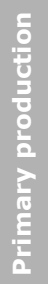 & $\frac{1}{3}$ & 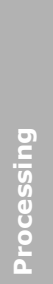 & $\begin{array}{l}\text { 등 } \\
\frac{7}{3} \\
\frac{2}{2} \\
\frac{2}{2} \\
\frac{\pi}{6}\end{array}$ & " & 훙 \\
\hline Dubrovnik/Opuzen & $\begin{array}{l}\text { Dubrovnik regional development agency } \\
\text { DUNEA }\end{array}$ & & & & & & & $x$ & & & & & & & & $x$ \\
\hline Dubrovnik/Opuzen & $\begin{array}{l}\text { Association of producers of mandarins } \\
\text { Neretva }\end{array}$ & & & & & & & $x$ & & & $x$ & & & & & \\
\hline Dubrovnik/Opuzen & Frigo Bonsai & $x$ & & & & & & $x$ & & & & $x$ & & & & \\
\hline Dubrovnik/Opuzen & AgroFructus Opuzen & $x$ & & & & & & $x$ & & & & $x$ & & $x$ & & \\
\hline Dubrovnik/Opuzen & Ivan Bjelis farm & $x$ & & $x$ & & & & & & & $x$ & & & & & \\
\hline Trogir/Zadar & Maraska d.d. & & & & & & & & $x$ & & $x$ & & $x$ & & & \\
\hline Trogir/Zadar & Tomas Ivica farm & $x$ & $x$ & & & & & & & & $x$ & & & & & \\
\hline Trogir/Zadar & Ratko Sliskovic farm & & $x$ & & & & & & $x$ & & $x$ & & & & & \\
\hline Trogir/Zadar & Obnova Trogir & $x$ & $x$ & $x$ & & & & & & & $x$ & $x$ & & & & \\
\hline Trogir/Zadar & $\begin{array}{l}\text { PIK Vinkovici production facilities and PIK } \\
\text { Vinkovici purchase centre Polaca }\end{array}$ & $x$ & & $x$ & $x$ & & & & & & $x$ & $x$ & & $x$ & & \\
\hline Slavonija & Klaster Slavonska Jabuka & & & & & & $x$ & & & & $x$ & & & & & \\
\hline Slavonija & $\begin{array}{l}\text { Association of garlic producers of Slavonija } \\
\text { and Baranja 'Slavonski Cesnjak' }\end{array}$ & & & & & $x$ & & & & & $x$ & & & & & \\
\hline Slavonija & Osatina d.o.o. & $x$ & $x$ & & & & & & & $x$ & $x$ & & & & & \\
\hline Slavonija & PIK Vinkovici & $x$ & & & & & & & & $x$ & $x$ & $x$ & $x$ & $x$ & & \\
\hline $\begin{array}{l}\text { Varazdin and North } \\
\text { West Croatia }\end{array}$ & Agro Međimurje d.d. & & & & & & $x$ & & & & $x$ & $x$ & $x$ & & & \\
\hline $\begin{array}{l}\text { Varazdin and North } \\
\text { West Croatia }\end{array}$ & Juriza Caufik farm & & & $x$ & $x$ & & & & & & $x$ & & & & & \\
\hline $\begin{array}{l}\text { Varazdin and North } \\
\text { West Croatia }\end{array}$ & Marko Hladika farm & & & $x$ & $x$ & & & & & & $x$ & & & & & \\
\hline $\begin{array}{l}\text { Varazdin and North } \\
\text { West Croatia }\end{array}$ & Petrokemja Kutina d.d. & $x$ & & & & & & & & $x$ & & & & & & \\
\hline Zagreb Region & Fragaria d.o.o. & $x$ & & & & & $x$ & & & $x$ & $x$ & & $x$ & & & \\
\hline Zagreb Region & Podravka d.d. & & $x$ & & & & & & & & $x$ & & $x$ & & & \\
\hline Zagreb Region & AgroFructus distribution center Sesvete & $x$ & & & & & & & & & & & & $x$ & & \\
\hline Zagreb Region & Spar Hrvatska & $x$ & & & & & & & & & & & & & $x$ & \\
\hline Zagreb Region & Konzum d.d. & $x$ & & & & & & & & & & & & & $x$ & \\
\hline Zagreb Region & Young Farmers Croatia & $x$ & & & & & & & & & $x$ & & & & & \\
\hline Zagreb & GEJA Savjetovanje d.o.o & $x$ & $x$ & $x$ & $x$ & $x$ & $x$ & $x$ & $x$ & $x$ & $x$ & $x$ & $x$ & $x$ & $x$ & $x$ \\
\hline
\end{tabular}




\section{Appendix 6 Country profile of Croatia}

The Republic of Croatia (Republika Hrvatska) is a country in the Balkans, connecting Central Europe to the Mediterranean. Croatia covers almost 57 thousand square kilometre, from the Danube river in the North-East to Istria in the West and along the Adriatic coast to the Konavle region in the South-East, including a large number of islands in the Adriatic Sea. The country is characterised by considerable natural and climatic diversity, which is reflected in the range of agricultural products, from traditional continental arable and industrial crops to vineyards and to Mediterranean fruits and vegetables.

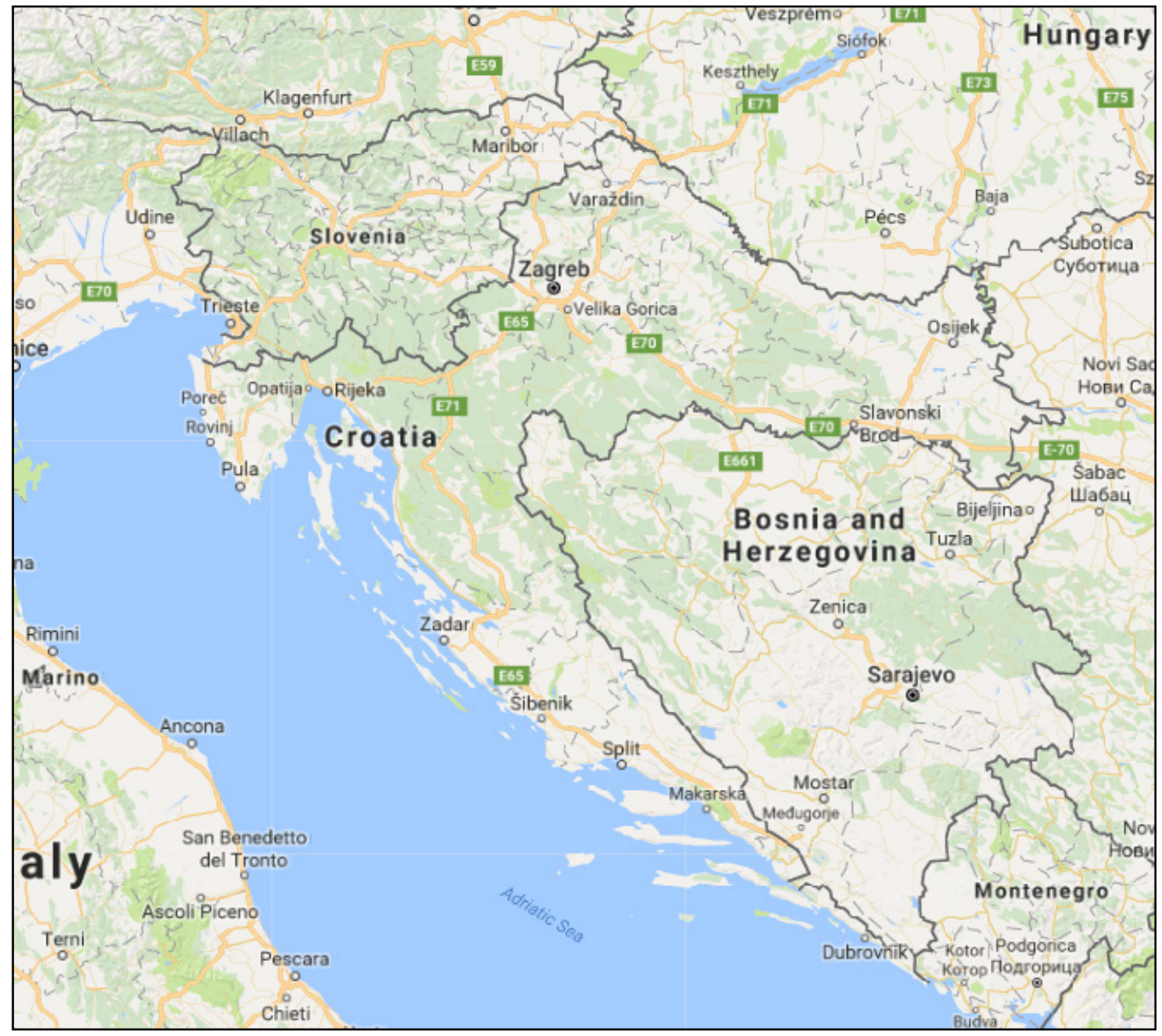

Figure A6.1 Map of Croatia Source: Google maps.

Croatia was part of formal Yugoslavia and is independent since 1991. The Croatian war of independency was fought from 1991 to 1995. On 1 July 2013 Croatia joined the EU. Croatia has a population of $4.2 \mathrm{~m}(0.8 \%$ of the EU-28 total and $0.57 \%$ of the European population). It is one of the least populated countries of the European Union (an average of 74 people per square kilometre, estimate for 2016), after Sweden and Finland, Ireland, the Baltic states and Bulgaria. 59\% of the population lives in urban areas. The Zagreb region and the northern parts of the country around Varazdin and the eastern Slavonian region around Osijek are the most densely populated. Larger cities at the Adriatic coast include Split, Dubrovnik, Zadar and Rijeka. 
The country's capital is Zagreb, a city with almost 800 thousand inhabitants (2011 census). Other major cities are Split (180 thousand population) and Rijeka (130 thousand). Croatia is divided in 21 counties (NUTS-3 counties), of which the city of Zagreb is one. For statistical purposes Croatia is further subdivided in two major regions (NUTS-2 regions) Jadranska Hrvatska (Adriatic Croatia) and Kontinentalna Hrvatska (Continental Croatia).

Only about $27 \%$ of the total land surface is utilised for agriculture, compared to $40 \%$ for the EU-28. About 34\% of the land area consists of forest, compared to 38\% in the EU-28 (Source: FAO derived from The World Bank). About half of the country is made up of Karst rocks, especially in the Adriatic region of the Dinaric Alps. In the Northwest, the Pannonian Basin plain covers among others the Slavonia and Baranya regions. The lowlands of the Pannonian Basin plain are the main agricultural areas in Croatia for the production of arable crops such as wheat and corn, while the coastal regions are more specialised in the cultivation of grapes, other fruit and olives.

The share of utilised agricultural land in total land surface is much lower than the EU average. This is besides natural causes - to a large extent caused by the fact that a lot of land is agricultural land that is not actually utilised. Arable crops and permanent grassland make up most of the agricultural area. Fresh vegetables, melons and strawberries were cultivated on just about 9 thousand hectares in 2015 (Eurostat). Fruit (excluding grapes) was grown on about 30 thousand hectares of which some 2.2 thousand hectares was citrus fruit.

Table A6.1 Key facts of Croatia compared to EU-28

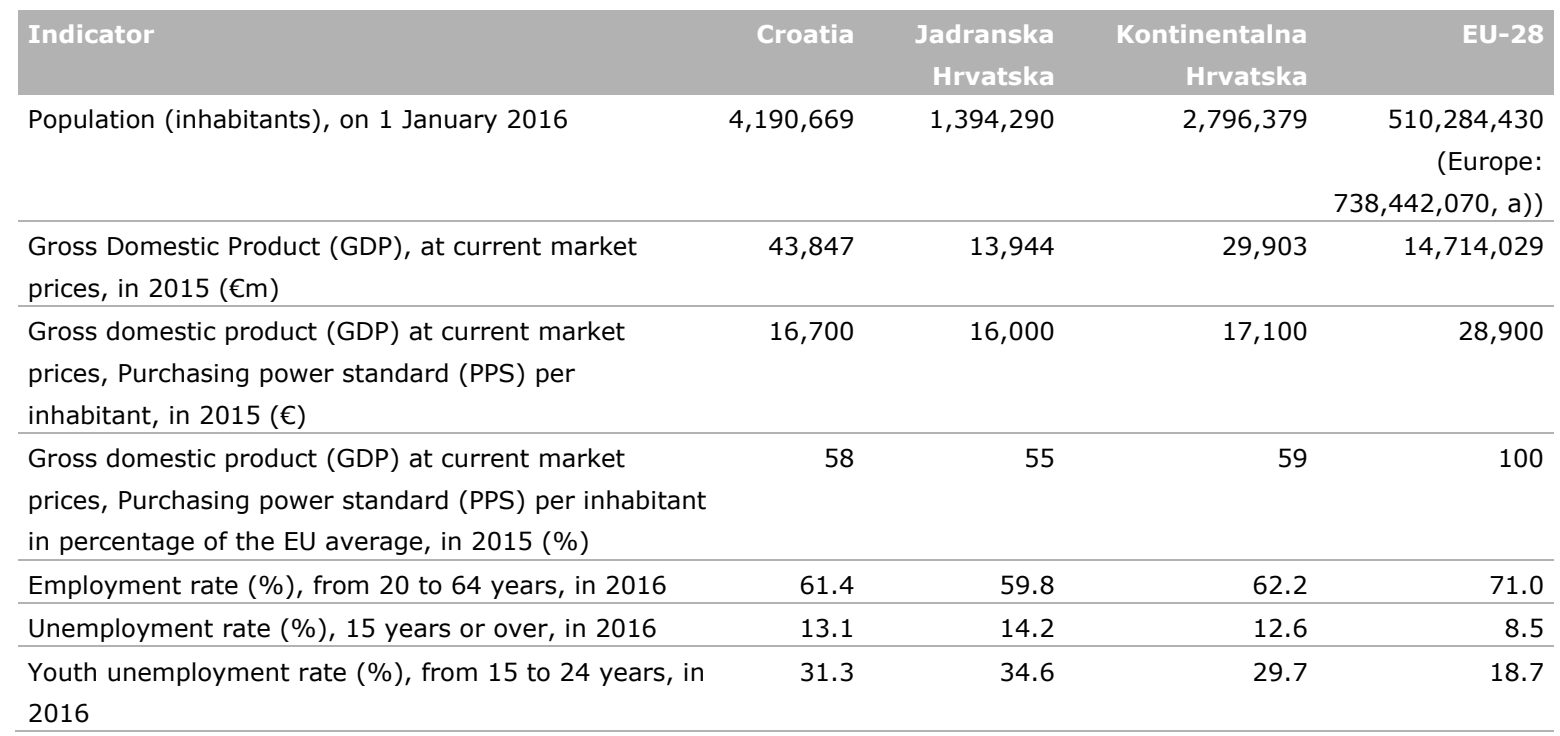

Source: Eurostat. a) FAOSTAT.

In terms of economic activity, Croatia has a diversified economy, with both industry, tourism as well as agricultural and trade activities. Looking to Eurostat statistics (2015) the financial services and insurance sector in Croatia ( $7 \%$ of total gross value added and income) is particularly large relative to the EU average (5\%). 'Professional, scientific and technical activities; administrative and support service activities', as well as 'Public administration, defence, education, human health and social work activities' have a somewhat lower share in total gross value added in comparison to the EU average. Agriculture, forestry and fishing makes up $4 \%$ of the total economy in terms of value added, compared to $1.5 \%$ in the EU-28. The share of agriculture, forestry and fishing has been decreasing from $5 \%$ to $4 \%$ of total income between 2007 and 2016 . 
Wageningen Economic Research P.O. Box 29703

2502 LS The Hague

The Netherlands

$\mathrm{T}+31(0) 703358330$

E communications.ssg@wur.nl

www.wur.eu/economic-research

Wageningen Economic Research REPORT

2018-002
The mission of Wageningen University and Research is "To explore the potential of nature to improve the quality of life". Under the banner Wageningen University \& Research, Wageningen University and the specialised research institutes of the Wageningen Research Foundation have joined forces in contributing to finding solutions to important questions in the domain of healthy food and living environment. With its roughly 30 branches, 5,000 employees and 10,000 students, Wageningen University \& Research is one of the leading organisations in its domain. The unique Wageningen approach lies in its integrated approach to issues and the collaboration between different disciplines.

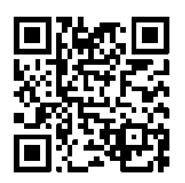





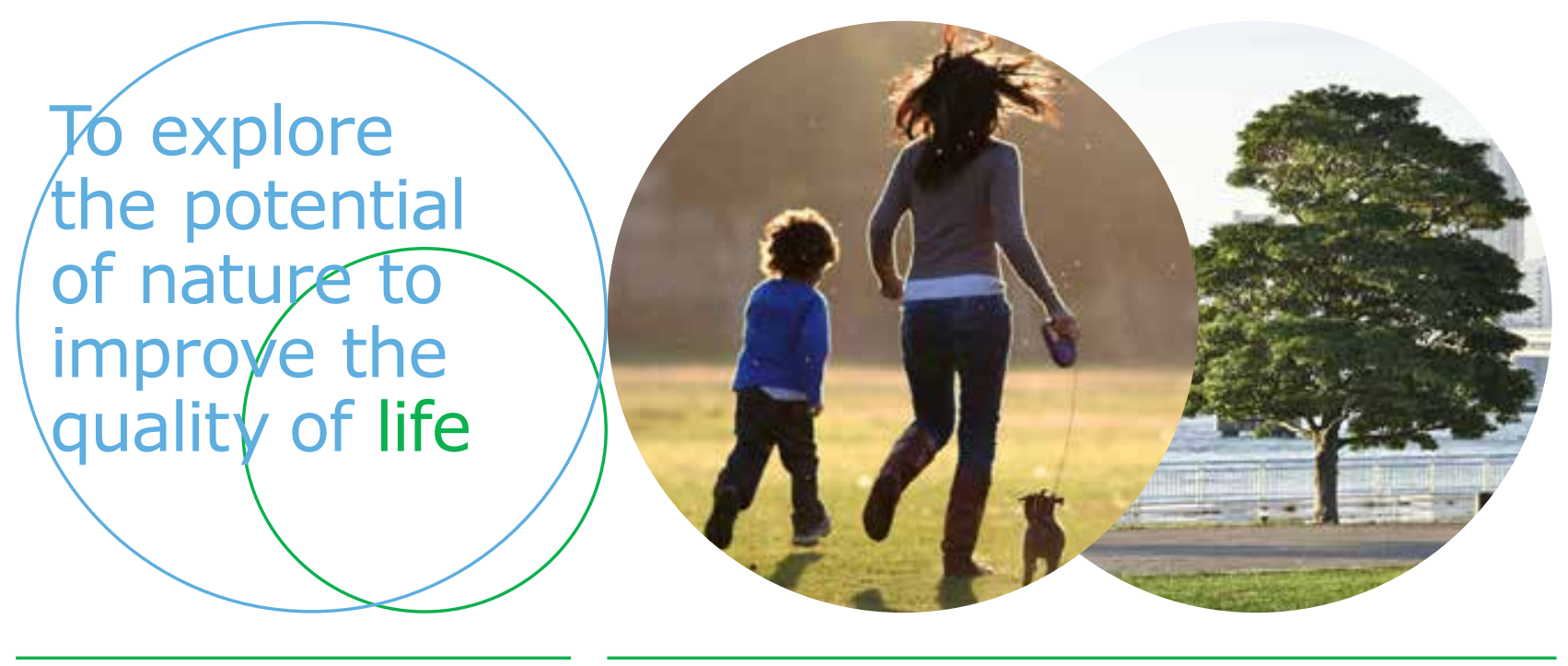

Wageningen Economic Research P.O. Box 29703

2502 LS Den Haag

The Netherlands

E communications.ssg@wur.nl

www.wur.eu/economic-research

Report 2018-002

ISBN 978-94-6343-761-5
The mission of Wageningen University and Research is "To explore the potential of nature to improve the quality of life". Under the banner Wageningen University \& Research, Wageningen University and the specialised research institutes of the Wageningen Research Foundation have joined forces in contributing to finding solutions to important questions in the domain of healthy food and living environment. With its roughly 30 branches, 5,000 employees and 10,000 students, Wageningen University \& Research is one of the leading organisations in its domain. The unique Wageningen approach lies in its integrated approach to issues and the collaboration between different disciplines.

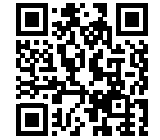

